\title{
2. SITES 336 AND 352
}

\author{
The Shipboard Scientific Party ${ }^{1}$ \\ With Additional Contributions From \\ Reidar L $\phi$ vlie, Universitetet i Bergen, Bergen, Norway \\ Svein B. Manum, Universitetet i Oslo, Oslo, Norway \\ H. Raschka and F.-J. Eckhardt, Bundesanstalt for Geowissenschaften \\ und Rohstoffe, Hannover, Germany \\ and \\ H.-J. Schrader, Der Universität Kiel, Kiel, Germany
}

\section{SITE DATA, SITE 336}

Position: $63^{\circ} 21.06^{\prime} \mathrm{N} ; 07^{\circ} 47.27^{\prime} \mathrm{W}$

Water Depth (from sea level): 811.0 corrected meters (echo sounding)

Bottom Felt at: 830.0 meters (drill pipe)

Penetration: 515.0 meters

Number of Holes: 1

Number of Cores: 44

Total Length of Cored Section: 396.5 meters

Total Core Recovered: 220.9 meters

Percentage of Core Recovery: $55.7 \%$

Oldest Sediment Cored:

Depth below sea floor: 463.0 meters

Nature: nonmarine claystone

Age: Middle or Late(?) Eocene (Core 37)

Measured velocity: $1.76 \mathrm{~km} / \mathrm{sec}$

Basement:

Depth below sea floor: 484.5 meters (drilled)

Nature: Fine-grained trachybasalt

Age: K/Ar-40-43 m.y. (late Eocene)

Principal Results: Site 336 penetrated a total depth of 515 meters, the last 30.5 meters being in basalt. The basalt, which is covered by rubble derived by weathering, was probably extruded subaerially. Subsequently the area has undergone subsidence. A mudstone from 168 meters to 463 meters of upper Oligocene to middle or upper Eocene age contains several well-defined ash layers and overlies the basalt. The topmost unit consists largely of clays and sands containing a large percentage of glacially derived material deposited in the Plio-Pleistocene. The data at this

\footnotetext{
${ }^{1}$ Manik Talwani, Lamont-Doherty Geological Observatory, Palisades, New York; Gleb B. Udintsev, P.P. Shirshov Institute of Oceanology, Moscow, USSR; Kjell Bj申rklund, Universitetet i Bergen, Bergen, Norway; V.N.D. Caston, British Petroleum Company Ltd., Middlesex, England; Richard W. Faas, Lafayette College, Easton, Pennsylvania; Jan E. van Hinte, Esso Production Research Company, Begles, France; G.N. Kharin, Atlantic Branch of Oceanology Institute, Kaliningrad, USSR; David A. Morris, Phillips Petroleum Company, Bartlesville, Oklahoma; Carla Müller, Geologisch-Paleontologisches Institut der Johann Wolfgang GoetheUniversität, Frankfurt am Main, Germany; Tor H. Nilsen, U.S. Geological Survey, Menlo Park, California; Detlef A. Warnke, California State University, Hayward, California; Stan M. White, University of California at San Diego, La Jolla, California.
}

site are not inconsistent with a Proto-Iceland type of origin for the Iceland-Faeroe Ridge, in which the spreading center was emergent, but the ridge gradually subsided and probably became completely submergent during the Miocene.

SITE DATA, SITE 352

Position: $63^{\circ} 38.97^{\prime} \mathrm{N} ; 12^{\circ} 28.26^{\prime} \mathrm{W}$

Water Depth (from sea level): 990.0 corrected meters (echo sounding)

Bottom Felt at: 1018.0 meters (drill pipe)

Penetration:

Hole 352: 103.5 meters

Hole 352A: 122.5 meters

Number of Holes: 2

Number of Cores:

Hole 352: 6

Hole 352A: 3

Total Length of Cored Section:

Hole 352: 46.0 meters

Hole 352A: 28.5 meters

Total Core Recovered:

Hole 352: 27.6 meters

Hole 352A: 5.1 meters

Percentage of Core Recovery:

Hole 352: $60.0 \%$

Hole $352 \mathrm{~A}: 17.2 \%$

Oldest Sediment Cored:

Depth below sea floor:

Hole 352: 54.5 meters

Hole $352 \mathrm{~A}: 122.5$ meters

Nature:

Hole 352: Gravels

Hole 352A: Nannofossil ooze

Age:

Hole 352: Middle Oligocene(?)

Hole 352A: Middle Oligocene

Principal Results: At this site on the southern flank of the Iceland-Faeroe Ridge, at least 54 meters of "glacial" sediments consisting of muds, sandy muds, and pebbly layers are present. They are rich in planktonic as well as benthonic foraminifera, but poor in nannoplankton and radiolarians. Pliocene and Miocene sediments are probably absent and the "glacial" sediments lie directly on middle Oligocene nannofossil oozes. These Oligocene sediments contrast greatly with the Oligocene sediments 
recovered at Site 336 on the northern flank of IcelandFaeroe Ridge, which are very poor in calcareous fossils. This suggests that the Iceland-Faeroe Ridge acted as a barrier against the mixing of North Atlantic and Norwegian Sea surface waters at least as late as the middle Oligocene.

\section{BACKGROUND AND OBJECTIVES-SITE 336}

\section{Bathymetry and General Description}

This site lies on the northern flank of the IcelandFaeroe Ridge. This ridge has an approximately northwest strike, and as its name implies, connects Iceland to the Faeroe Islands. Topographically it is a smooth ridge; the depth along its crest varies from slightly under 300 meters to over 400 meters (Figure 1). To the northeast, the Iceland-Faeroe Ridge slopes down steeply into the Norway Basin and to the southwest, less steeply into the oceanic basin east of the Reykjanes Ridge.

The crestal portion of the ridge has very thin sediment cover. Rock outcrops occur in several areas; the shallowest area (less than $400 \mathrm{~m}$, shown by diagonal shading in the bathymetric chart, Chapter 34 , this volume), is generally bare of sediment although some sediment pockets exist on the ridge. Both the southwest and the northeast flanks are covered by sediment, which is smooth and thick on the northeastern flank, but thinner and more broken up on the southwestern flank. Topographically Site 336 lies on the smooth eastern flank; on a sediment isopach map it lies on the northwest side of a sediment filled valley which cuts into the northeast flank of the Iceland-Faeroe Ridge.

\section{Origin}

There is no general agreement about the origin of the Iceland-Faeroe Ridge. The preponderant opinion at the present time appears to be that this ridge represents the trail of a hot spot underneath a spreading ridge; the present position of the hot spot being under Iceland. More refined versions of this scheme suggest that there also has been a westward jump of the ridge axis from the Iceland-Faeroe Ridge to Iceland about 30 m.y. ago. Some scientists, however, believe that the IcelandFaeroe Ridge has not been created by seafloor spreading, but is a subsided continental fragment. Any basalt cover would be attributed to the large amount of magmatic activity in the Brito-Arctic province.

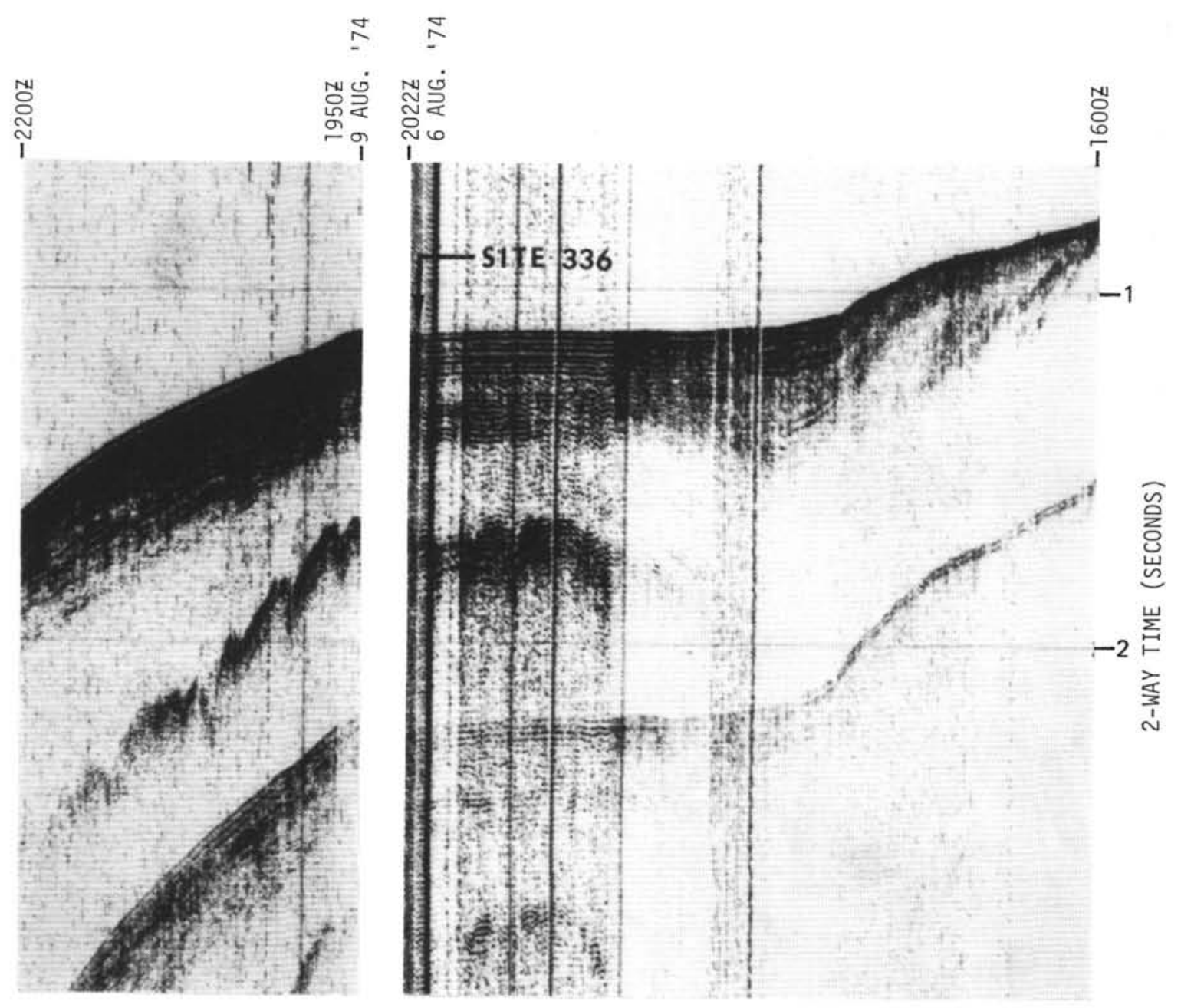

Figure 1. Profiler record - Site 336. 
Some long wavelength magnetic anomalies exist over the ridge especially in the southwest portion, and correlations have been tentatively suggested by Johnson and Tanner (1973). These correlations imply that the southwest flank of the Iceland-Faeroe Ridge is simply a northeast continuation of the basin east of the Reykjanes Ridge as far as age relationships are concerned.

\section{Subsidence of the Iceland-Faeroe Ridge}

There has been speculation that the Iceland-Faeroe Ridge has undergone subsidence. An emergent ridge would act as the "Thulean Land Bridge" for mammals between Eurasia and America, and also prevent the Arctic and Atlantic waters and the marine fauna from mixing across this boundary.

\section{Location and Site Objectives}

Site 336 is located in about 800 meters of water with about 500 meters of sediment. The top part of the sediment shows layering and a prominent reflector exists at 0.2 seconds (double reflection time) (Figure 1). Below this, the sediment is relatively homogenous. The site objectives were as follows:

1. To obtain samples of basement that are not badly weathered. To determine age of basement, and try to determine its origin. If igneous, is the basement derived from a primordial "plume" magma as proposed by Schilling for Iceland?

2. From paleontological evidence, to determine age of sediments, hiatuses, and possibly the history of subsidence.

3. From paleontological evidence, essentially by comparison with fauna of Site 352, to determine time of submergence of Iceland-Faeroe Ridge.

4. The calcareous and siliceous fossil associations are expected to have a mixed temperate-Atlantic and coolArctic character, and can be instrumental in tying high latitude zonations to the warm standard zonal scheme, and consequently to the numerical timescale. This would not only be of great value, in general, but would be of particular value during this cruise.

5. A comparison of the biohistories of Sites 336 and 352 will reveal the history of the warm Gulf Stream influences to the south and to the north of the ridge, at least for as far back as Neogene times.

6. An additional objective is the determination of those faunal and floral associations that indicate (Neogene) climatic fluctuations. Tied in with these efforts, is the identification of the beginning of ice rafting in this area, and the relationship of this occurrence to the Plio-Pleistocene boundary and other stratigraphic boundaries.

7. Volcanic layers will be examined for possible use as a marker horizon, and for possible correlation with times of climatic cooling as established by other means.

8. Try to establish the source of any terrigenous sediments.

\section{BACKGROUND AND OBJECTIVES-SITE 352}

The objectives at Site 352 on the southern flank of the Iceland-Faeroe Ridge (Figure 2) were very similar to the objectives at Site 336 on the northern flank: to obtain samples of basement rocks in order to determine their nature and age; to examine the sediments cored, as well as basement rocks to learn about the history of subsidence of the Iceland-Faeroe Ridge. In this regard, it is believed that would be very useful to compare the fauna at Sites 336 and 352 to learn about the time of connection between the Norwegian Sea and the North Atlantic.

\section{OPERATIONS, SITE 336}

\section{Approach to Site 336}

Site 336 was approached from the south on 6 August on course $006^{\circ}$ at normal speed (210 rpm). At 1730Z, the heading was altered to $045^{\circ}$, and at $1741 \mathrm{Z}$ to $358^{\circ}$, with a reduction in speed to $150 \mathrm{rpm}$. A $13-\mathrm{kHz}$ beacon was dropped at $2022 \mathrm{Z}$, after which the ship maneuvered to return to the site of the beacon drop (Figures 1,3).

\section{Drilling Operations}

In order to conserve long-lead drilling equipment, and prolong bit life, the standard BHA was modified to include one LSB above, and one below the center drill column. A medium size insert tooth, four cone, fournal-bearing bit, with intact full length core guides was used. The BHA was run to within a few meters of sea bed by $0430 \mathrm{hr}, 7$ August. At this time, a delay of 5 $\mathrm{hr}$ was caused while attempting to commission the motion compensator.

An initial water core was recovered from a depth corresponding to 9 meters below the PDR depth. The first sediment core was recovered at $1241 \mathrm{hr}, 7$ August, establishing sea bed at 830 meters (drill pipe measurement). Continuous coring was commenced and continued from 830 meters to 913 meters. Poor recoveries from Cores 3 and 4, and in particular Core 7, were attributed to unconsolidated material, and friable sand intervals.

The technique of washing and control coring was adopted between 913 meters and 1008 meters. In spite of the relatively poor recoveries due to the wash/core techniques, there was sufficient recovery for control purposes. Continuous coring was adopted from 1008 meters to 1131.5 meters.

It was decided at $1300 \mathrm{hr}$ on 8 August to wash down with alternate control cores. The hole was deepened 166 meters, from 1131.5 meters to 1297.5 meters. Continuous coring was readopted from 1297.5 meters to total depth of 1345 meters.

From the total cored section, a recovery of 220.9 meters $(55.7 \%$ ) was achieved (Table 1). No evidence of gas was encountered, and the hole was abandoned according to safety regulations at $1630 \mathrm{hr}, 9$ August.

\section{OPERATIONS, SITE 352}

\section{Approach to Site $\mathbf{3 5 2}$}

Glomar Challenger approached Site 352 on 19 September after steaming $146 \mathrm{n} \mathrm{mi}$, including surveying, in $16 \mathrm{hr}, 15 \mathrm{~min}$, at an average speed of 8.9 knots. At $0245 Z, 19$ September, speed was reduced to 6 knots $(150 \mathrm{rpm})$, and at $0300 \mathrm{Z}$ the course was corrected to $140^{\circ}$ (Figure 4). The beacon was dropped at $0313 \mathrm{Z}$, and the ship continued on the same course and speed until 0550Z, at which time she maneuvered to return to the site of the beacon drop (Figure 2). 


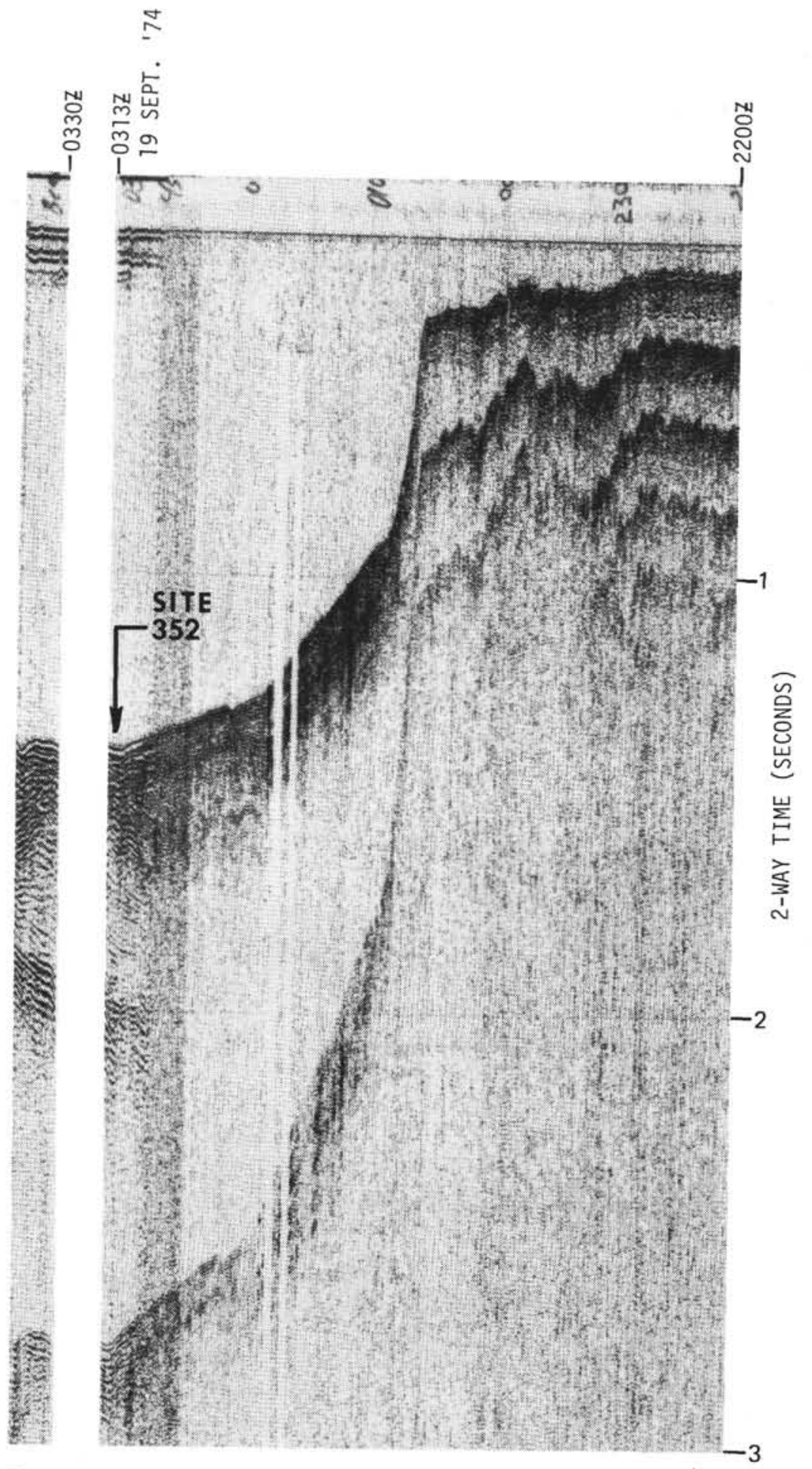

Figure 2. Profiler record - Site 352.

The storm experienced at Site 351 abated during the journey, but a strong, confused swell persisted. Some $5.75 \mathrm{hr}$ elapsed while maneuvering the Challenger and fixing position on the beacon.

\section{Drilling Operations, Hole 352}

A standard compact size core bit was run with the extra-length BHA for anticipated deeper coring into basement. After taking a water core, sea bed was confirmed at 1018 meters. Continuous coring was aban- doned in favor of washing after reaching 1056 meters (38 m BSB), as there were strong indications that sand and gravel was sloughing into the hole. When circulation was stopped, it was difficult to reestablish, and the core bit became temporarily plugged.

After purging the hole with 25 barrels of gel mud, the center bit was dropped to allow drilling in an attempt to penetrate the sloughing section and bury the BHA. At this stage, six cores, totaling 46 meters, had been attempted and 27.6 meters recovered (60\%) (Table 2). 


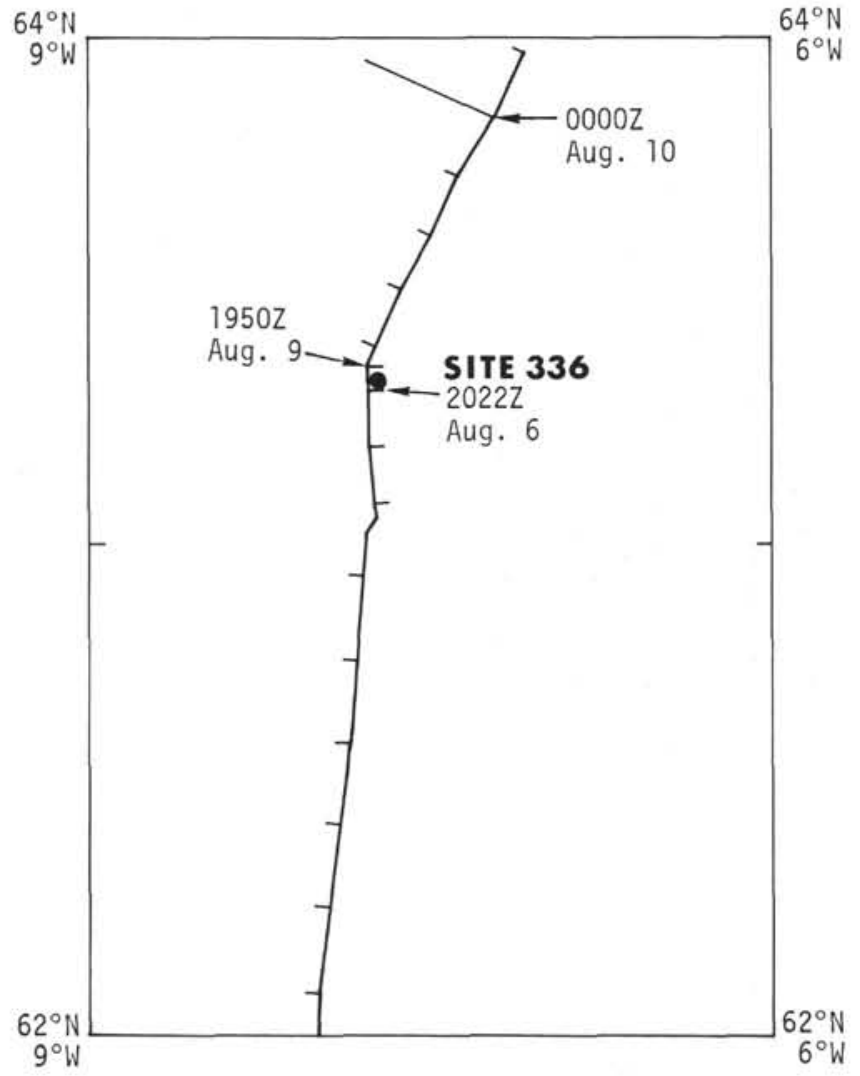

Figure 3. Track chart - Site 336.

When preparing to take a core at 1121.5 meters (103.5 m BSB), it became necessary to recover the drilling assembly above sea bed due to a combination of swell, 2 knot current, and wind. These factors overtaxed the position-keeping capability, and threatened engine overloading. The BHA was recovered above sea bed at $2245 \mathrm{hr}, 19$ September, and the hole was abandoned.

\section{Drilling Operations, Hole 352A}

Hole $352 \mathrm{~A}$ was spudded in at $0000 \mathrm{hr}, 20$ September as a replacement for Hole 352 . The hole was washed to 94 meters BSB, before beginning continuous coring to 1140.5 meters (122.5 m BSB). Weather conditions again made station keeping impossible, and the BHA was pulled above sea bed at $0645 \mathrm{hr}, 20$ September, and subsequently to surface and the hole abandoned. From the 28.5 meters cored, 5.1 meters or $17.2 \%$ was recovered (Table 2).

\section{LITHOLOGY, SITE 336}

Approximately 221 meters of sediments, sedimentary rocks, and basalt were recovered from 44 cores taken at Site 336. Three major sedimentary units (Units 1, 2, and 3 ), and one basaltic unit (Unit 4) were distinguished. Subunits were also designated on observational and significant characteristics (Table 3, Figure 5).

\section{Unit Descriptions}

\section{Unit 1}

This unit is composed of muds, sandy muds, and clays, generally soft, with moderate to intense deforma- tion. Local color mottling may reflect a relict bedding, particularly in Subunit A; however, a very thin stratification $(1-5 \mathrm{~cm})$ is apparent in Subunits B and C. In Subunit B, this stratification may be indicative of distal turbidites, or repetitively interstratified variations in hemipelagic sedimentation. In Subunit $C$, the stratification may indicate a decreased sedimentation rate, which is also suggested by the downhole increase in glauconite.

Smear slides contain terrigenous components, and zones of scattered pebbles indicate probable ice rafting. Detrital mineral grains, which include zircon, are subrounded. Nannofossils, radiolarians, foraminifera, diatoms, and sponge spicules are also present (1\%$10 \%)$. Sedimentary structures, particularly in Subunit B include: graded bedding in some sands and sandy muds, thin $(2 \mathrm{~mm}-1 \mathrm{~cm})$ laminations, and bioturbation. Although the base of Unit 1 coincided with the presence of a black glauconitic sand in Sample 14, CC, this sand may be a washed concentrate of sedimentary material not recovered in Cores 13 and 14 .

Grain size analyses indicate that muds predominate, with sandy muds present in Cores 8,9 , and 10 . The sand content ranges from $2.2 \%$ to $69.1 \%$. The $\mathrm{CaCO}_{3}$ content ranges from $2 \%$ to $12 \%$, showing a slight tendency to decrease with depth.

\section{Unit 2}

This unit is more lithified, particularly toward the base (Core 24, $254 \mathrm{~m}$ ). It contains glauconite, a greater amount of siliceous biogenic material (radiolarians, diatoms, and sponge spicules), shows color mottling, and bioturbation. These characteristics suggest a low sedimentation rate. Well-defined volcanic ash strata are locally present. Muds dominate and have a sand content of $0.0 \%$ to $48.2 \%$, definitely a lower range than found in Unit $1 . \mathrm{CaCO}_{3}$ contents are variable $(2 \%$ $61 \%)$.

\section{Unit 3}

This unit, as defined, consists of three distinctive subunits, which may form continuous gradational sequence (Table 3). The subunits in descending order are: reddish clay, a red-yellow claystone, and a volcanic rubble.

Extensive postdepositional mineralization (?) has apparently taken place in Subunit B; however both subunits (A and B) appear to have developed from extensive subaerial weathering of the underlying basalt unit, with subsequent mineralization (?).

Subunit $3 \mathrm{C}$ is a rubble containing clasts of volcanic rock in a whitish, clayey matrix. The subrounded nature of the clasts and upward decrease in grain size may have resulted from either weathering of the underlying basalt, or reworking of volcanic material derived from erosion of the basalt. The presence of subrounded volcanic clasts in overlying Subunit B may perhaps be attributed to gravity transfer (slope wash) of material. The mineralization (?) that affected Subunit B also affected Subunit C; the matrix and clasts have been altered to clays; however, their shape, and evidence of an original vesicular, basaltic nature have been retained.

Grain size samples were not taken. The $\mathrm{CaCO}_{3}$ content ranges from $0 \%$ to $1 \%$ for four samples. 
TABLE 1

Coring Summary, Site 336

\begin{tabular}{|c|c|c|c|c|c|c|c|}
\hline Core & $\begin{array}{l}\text { Date } \\
\text { (August } \\
\text { 1974) }\end{array}$ & Time & $\begin{array}{l}\text { Depth From } \\
\text { Drill Floor } \\
(\mathrm{m})\end{array}$ & $\begin{array}{l}\text { Depth Below } \\
\text { Sea Floor } \\
\text { (m) }\end{array}$ & $\begin{array}{l}\text { Cored } \\
(\mathrm{m})\end{array}$ & $\begin{array}{l}\text { Recovered } \\
(\mathrm{m})\end{array}$ & $\begin{array}{c}\text { Recovery } \\
(\%)\end{array}$ \\
\hline 1 & 7 & 1241 & $830.0-837.0$ & $0.0-7.0$ & 7.0 & 7.0 & 100 \\
\hline 2 & 7 & 1324 & $837.0-846.5$ & $7.0-16.5$ & 9.5 & 5.7 & 60 \\
\hline 3 & 7 & 1415 & $846.5-856.0$ & $16.5-26.0$ & 9.5 & 3.2 & 34 \\
\hline 4 & 7 & 1455 & $856.0-865.5$ & $26.0-35.5$ & 9.5 & 2.0 & 21 \\
\hline 5 & 7 & 1552 & $865.5-875.0$ & $35.5-45.0$ & 9.5 & 9.2 & 97 \\
\hline 6 & 7 & 1640 & $875.0-884.5$ & $45.0-54.5$ & 9.5 & 9.5 & 100 \\
\hline 7 & 7 & 1734 & $884.5-894.0$ & $54.5-64.0$ & 9.5 & 0.2 & 2 \\
\hline 8 & 7 & 1830 & $894.0-903.5$ & $64.0-73.5$ & 9.5 & 9.3 & 98 \\
\hline 9 & 7 & 1910 & $903.5-913.0$ & $73.5-83.0$ & 9.5 & 6.8 & 72 \\
\hline Washed & & & $913.0-922.5$ & $83.0-92.5$ & & & \\
\hline 10 & 7 & 2017 & $922.5-932.0$ & $92.5-102.0$ & 9.5 & 1.8 & 19 \\
\hline Washed & & & $932.0-941.5$ & $102.0-111.5$ & & & \\
\hline 11 & 7 & 2125 & $941.5-951.0$ & $111.5-121.0$ & 9.5 & 4.9 & 52 \\
\hline Washed & & & $951.0-960.5$ & $121.0-130.5$ & & & \\
\hline 12 & 7 & 2215 & $960.5-970.0$ & $130.5-140.0$ & 9.5 & 3.0 & 32 \\
\hline Washed & & & $970.0-979.5$ & $140.0-149.5$ & & & \\
\hline 13 & 7 & 2305 & $979.5-989.0$ & $149.5-159.0$ & 9.5 & 0.2 & 2 \\
\hline 14 & 7 & 2345 & $989.0-998.5$ & $159.0-168.5$ & 9.5 & 0.0 & 0 \\
\hline 15 & 8 & 0045 & $998.5-1008.0$ & $168.5-178.5$ & 9.5 & 1.5 & 16 \\
\hline 16 & 8 & 0140 & $1008.0-1017.5$ & $178.0-187.5$ & 9.5 & 8.1 & 85 \\
\hline 17 & 8 & 0220 & $1017.5-1027.0$ & $187.5-197.0$ & 9.5 & 0.2 & 2 \\
\hline 18 & 8 & 0450 & $1027.0-1036.5$ & $197.0-206.5$ & 9.5 & 7.4 & 78 \\
\hline 19 & 8 & 0545 & $1036.5-1046.0$ & $206.5-216.0$ & 9.5 & 2.1 & 22 \\
\hline 20 & 8 & 0640 & $1046.0-1055.5$ & $216.0-225.5$ & 9.5 & 9.5 & 100 \\
\hline 21 & 8 & 0730 & $1055.5-1065.0$ & $225.5-235.0$ & 9.5 & 8.4 & 88 \\
\hline 22 & 8 & 0820 & $1065.0-1074.5$ & $235.0-244.5$ & 9.5 & 9.5 & 100 \\
\hline 23 & 8 & 0915 & $1074.5-1084.0$ & $244.5-254.0$ & 9.5 & 8.4 & 88 \\
\hline 24 & 8 & 1000 & $1084.0-1093.5$ & $254.0-263.5$ & 9.5 & 9.5 & 100 \\
\hline 25 & 8 & 1045 & $1093.5-1103.0$ & $263.5-273.0$ & 9.5 & 9.5 & 100 \\
\hline 26 & 8 & 1140 & $1103.0-1112.5$ & $273.0-282.5$ & 9.5 & 9.7 & 100 \\
\hline 27 & 8 & 1250 & $1112.5-1122.0$ & $282.5-292.0$ & 9.5 & 9.7 & 100 \\
\hline 28 & 8 & 1335 & $1122.0-1131.5$ & $292.0-301.5$ & 9.5 & 5.4 & 54 \\
\hline Washed & & & $1131.5-1141.0$ & $301.5-311.0$ & & & \\
\hline 29 & 8 & 1445 & $1141.0-1150.5$ & $311.0-320.5$ & 9.5 & 2.4 & 25 \\
\hline Washed & & & $1150.5-1160.0$ & $320.5-330.0$ & & & \\
\hline 30 & 8 & 1530 & $1160.0-1169.5$ & $330.0-339.5$ & 9.5 & 9.6 & 100 \\
\hline Washed & & & $1169.5-1179.0$ & $339.5-349.0$ & & & \\
\hline 31 & 8 & 1625 & $1179.0-1188.5$ & $349.0-358.5$ & 9.5 & 4.0 & 42 \\
\hline Washed & & & $1188.5-1198.0$ & $358.5-368.0$ & & & \\
\hline 32 & 8 & 1735 & $1198.0-1207.5$ & $368.0-377.5$ & & & \\
\hline $\begin{array}{l}\text { Washed } \\
33\end{array}$ & 8 & 1855 & $\begin{array}{l}1207.5-1217.0 \\
1217.0-1226.5\end{array}$ & $\begin{array}{l}377.5-387.0 \\
387.0-396.5\end{array}$ & 9.5 & 8.8 & 93 \\
\hline Washed & & & $1226.5-1236.0$ & $396.5-406.0$ & & & \\
\hline 34 & 8 & 1940 & $1236.0-1245.5$ & $406.0-415.5$ & 9.5 & 0.0 & 0 \\
\hline Washed & & & $1245.5-1255.0$ & $415.5-425.0$ & & & \\
\hline 35 & 8 & 2035 & $1255.0-1264.5$ & $425.0-434.5$ & 9.5 & 7.7 & 81 \\
\hline 36 & 8 & 2135 & $1264.5-1274.0$ & $434.5-444.0$ & 9.5 & 8.5 & 89 \\
\hline Washed & & & $1274.0-1283.5$ & $444.0-453.5$ & & & \\
\hline 37 & 8 & 2315 & $1283.5-1293.0$ & $453.5-463.0$ & 9.5 & 1.2 & 13 \\
\hline Washed & & & $1293.0-1297.5$ & $463.0-467.5$ & & & \\
\hline 38 & 9 & 0100 & $1297.5-1302.5$ & $467.5-472.5$ & 5.0 & 0.6 & 12 \\
\hline 39 & 9 & 0245 & $1302.5-1312.0$ & $472.5-482.0$ & 9.5 & 7.5 & 79 \\
\hline 40 & 9 & 0440 & $1312.0-1314.5$ & $482.0-484.5$ & 2.5 & 1.2 & 48 \\
\hline 41 & 9 & 0625 & $1314.5-1316.5$ & $484.5-486.5$ & 2.0 & 1.4 & 70 \\
\hline 42 & 9 & 0945 & $1316.5-1326.0$ & $486.5-496.0$ & 9.5 & 2.7 & 28 \\
\hline 43 & 9 & 1235 & $1326.0-1335.5$ & $496.0-505.5$ & 9.5 & 1.2 & 13 \\
\hline 44 & 9 & 1550 & $1335.5-1345.0$ & $505.5-515.0$ & 9.5 & 2.2 & 23 \\
\hline Total & & & 1345.0 & 515.0 & 396.5 & 220.9 & 55.7 \\
\hline
\end{tabular}

\section{Interpretations}

The geologic history, following extrusion of the basalt, of this part of the Iceland-Faeroe Ridge (Site 336) consists of:

1) Weathering or erosion of the basalt to yield all of Unit 3, or Subunit C. This was followed by mineralization (?).
2) Unit 2, the generally massive muds, occasional sandy muds, and clays indicate Eocene (?) to Oligocene hemipelagic sedimentation with sporadic deposition of volcanic ash.

3) A stratigraphic hiatus from the late Oligocene to the Pliocene (?) is present in Unit 1 . However, a coring gap in Cores 13 and 14 does not allow adequate definition of its boundaries. A hiatus of any extent may 


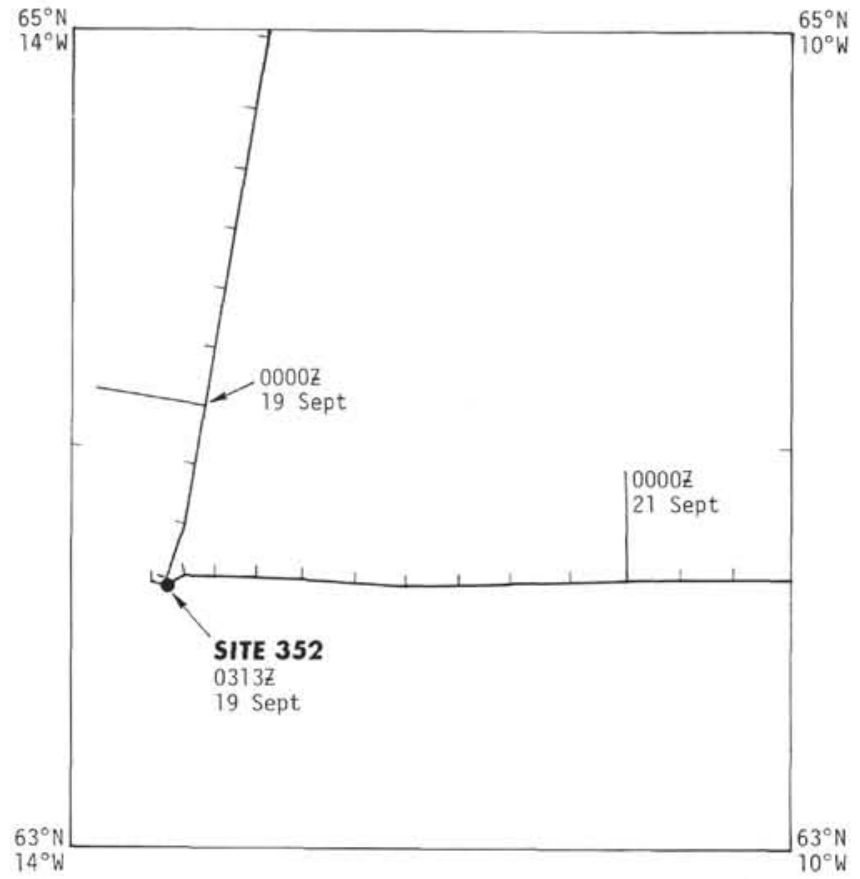

Figure 4. Track chart - Site 352.

reflect a history of emergence, increased bottom water erosion, or nondeposition. The latter reflects climatic trends particularly in Arctic regions (where most of the cold bottom water is generated at present). It is also possible to invoke a combination of factors, where topographically high submarine areas may cause an increase in current speeds of newly formed water masses, resulting in nondeposition and/or erosion.

4) Unit 1 indicated an initial (Subunit C) low sedimentation rate, increasing upwards to Subunit A. The sediments are admixed with coarse ice-rafted debris, which contributed to a high sedimentation rate during the Pliocene (?)-Pleistocene (see below).

\section{History of Ice Rafting}

The upper portions of the drilled section (Cores 1-13) have ice-rafted components in varying amounts. Some climatic references can be drawn from a crude approximation of the amount of ice-rafted material per unit volume of sediment. Six cc of sediment from each available core catcher was deflocculated, acidified, and sieved through a $44 \mu \mathrm{m}$ sieve. This was followed by an estimate of the remaining volume of the coarse fraction using a micropaleo slide as a volumetric device. This estimate, however, yields a nonclimate sensitive index, because of the large amounts of volcanic and biogenic admixtures. Point counting of 300 grains, however, yielded a relative frequency of light-mineral grains (predominantly quartz), which is a more reliable indicator of ice rafting, especially since a number of quartz grains displays breakage features.

The resulting frequency curve (Figure 6) is a first approximation of the intensity of ice rafting which, in turn, in this area may be a direct indicator of climatic conditions. The curve clearly shows the initiation of ice rafting with Core 13 (above the hiatus separating the late Oligocene from the Pliocene). There is also a reasonably good agreement between the curve representing ice rafting, and the paleoclimatic curve based on radiolarian indices. A significant discrepancy exists only in Core 2, where severe difficulties in disaggregation of clay-sized material negatively influenced the count.

Several large climatic oscillations (as indicated by ice rafting) are clearly shown. However, because of the large sampling interval, no inferences concerning the number of climatic oscillations (number of pulses of ice-rafting activity) can be drawn. Nevertheless, the data shown here, and the reasonable agreement with the paleoclimatic curve based on radiolarians, show: (a) the initiation of ice rafting during or after the hiatus, (b) significant climatic oscillations after the beginning of

TABLE 2

Coring Summary, Site 352

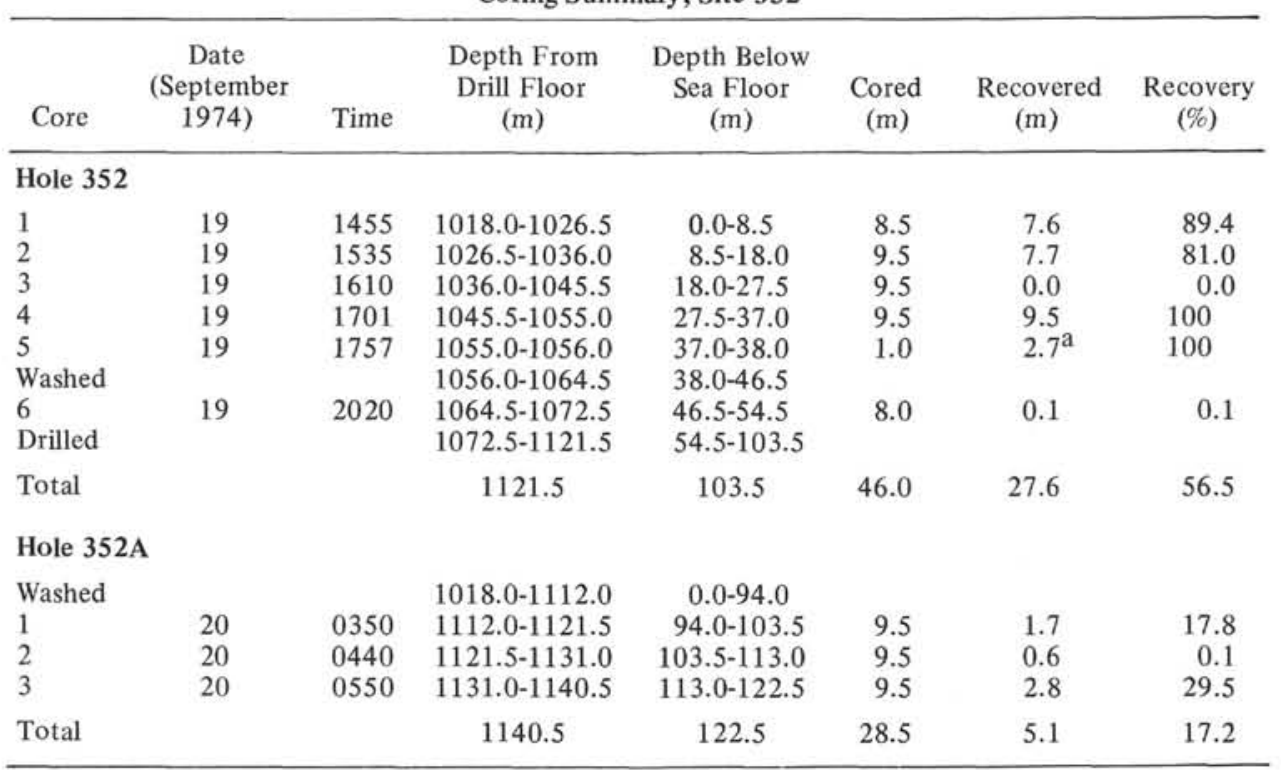

${ }^{\mathrm{a} C}$ Contamination from up-hole. 
TABLE 3

Lithologic Summary, Site 336

\begin{tabular}{|c|c|c|c|}
\hline Unit & $\begin{array}{l}\text { Depth }(\mathrm{m}) \text { and } \\
\text { Core Numbers }\end{array}$ & Age & Characteristics \\
\hline$\stackrel{1}{\text { Subunit A }}$ & $\begin{array}{l}0.0-77.0 \\
(1)-(9-4)\end{array}$ & $\begin{array}{l}\text { Upper Oligocene } \\
\text { to Plio-Pleistocene }\end{array}$ & $\begin{array}{l}\text { Generally gray clay, mud, and } \\
\text { sandy mud; soft, highly disturbed, } \\
\text { without apparent stratification } \\
\text { (massive); scattered pebbles noted } \\
\text { in Sections 5-2 to } 9-4\end{array}$ \\
\hline Subunit B & $\begin{array}{c}77.0-113.0 \\
(9-4)-(11-2)\end{array}$ & & $\begin{array}{l}\text { Gray, thinly interstratified lam- } \\
\text { inated clay, sand, mud, sandy } \\
\text { mud, sandy clay; graded beds and } \\
\text { distal turbidite structures locally } \\
\text { present }\end{array}$ \\
\hline Subunit C & $\begin{array}{l}113.0-168.5 \\
(11-2)-(14, \mathrm{CC})\end{array}$ & & $\begin{array}{l}\text { Gray, olive, brown, partly lam- } \\
\text { inated, massive, soft, mud clay, } \\
\text { sand and silt, scattered pebbles } \\
\text { noted in Section } 12-1 \text {. }\end{array}$ \\
\hline$\stackrel{2}{2}$ & $\begin{array}{l}168.5-200.0 \\
(15)-(18-4)\end{array}$ & $\begin{array}{l}\text { Middle or upper } \\
\text { Oligocene } \\
\text { (with Eocene?) }\end{array}$ & $\begin{array}{l}\text { Gray, olive, firm, stiff mudstone } \\
\text { with increased amounts of } \\
\text { siliceous biogenic components, } \\
\text { glauconite, and bioturbation }\end{array}$ \\
\hline Subunit B & $\begin{array}{l}200.0-252.5 \\
(18-4)-(23-5)\end{array}$ & & $\begin{array}{l}\text { Green, olive mudstone with } \\
\text { increasing amounts of glauconite } \\
\text { down to } 21-3 \text {, decreasing below } \\
21-3 \text {; increased lithification at } \\
\text { Core } 20\end{array}$ \\
\hline Subunit C & $\begin{array}{l}252.5-463.0 \\
(23-5)-(37, \mathrm{CC})\end{array}$ & $\begin{array}{l}\text { Middle or upper } \\
\text { Eocene and } \\
\text { upper Eocene }\end{array}$ & $\begin{array}{l}\text { Gray, olive, green, generally } \\
\text { massive, bioturbated mud/mud- } \\
\text { stone sandy mud/mudstone, } \\
\text { clay/claystone; subunit very stiff } \\
\text { beginning at Core } 24, \text { with mud- } \\
\text { stone present in Core } 28\end{array}$ \\
\hline $\begin{array}{c}3 \\
\text { Subunit A }\end{array}$ & $\begin{array}{l}463.0-472.5 \\
(37)-(39)\end{array}$ & $\begin{array}{l}\text { Middle or upper } \\
\text { Eocene (?) or } \\
\text { older }\end{array}$ & $\begin{array}{l}\text { Dusky red, moderate red, } \\
\text { extremely fine grained, firm } \\
\text { massive clay/claystone with large } \\
\text { amounts of hematite }\end{array}$ \\
\hline \multirow[t]{2}{*}{ Subunit B } & $\begin{array}{l}472.5- \pm 476.1 \\
(39)-(39-3)\end{array}$ & & $\begin{array}{l}\text { Moderate red, extremely fine } \\
\text { grained claystone, apparently } \\
\text { extensively altered by minerali- } \\
\text { zation (?) }\end{array}$ \\
\hline & $476.1-476.4$ & & $\begin{array}{l}\text { Extensive altered/mineralization } \\
\text { (?) zone; gradational contact to } \\
\text { Subunit C }\end{array}$ \\
\hline Subunit C & $\begin{array}{l}476.4-484.5 \\
(39-3)-(40-1)\end{array}$ & & $\begin{array}{l}\text { Blackish-red, brown, altered con- } \\
\text { glomerate breccia composed of } \\
\text { subrounded to subangular } \\
\text { altered clasts of volcanic rock } \\
(1 \mathrm{~mm}-40 \mathrm{~mm} \text { in diameter }) \text { in } \\
\text { altered matrix }\end{array}$ \\
\hline 4 & $\begin{array}{l}484.5-515.0 \\
(41)-(44)\end{array}$ & & $\begin{array}{l}\text { Gray, fine-grained basalt with } \\
\text { near vertical oriented, sheared } \\
\text { zones, and abundant, discon- } \\
\text { tinuous narrow veins filled with } \\
\text { calcite }\end{array}$ \\
\hline
\end{tabular}

${ }^{\mathrm{a}}$ Core numbers in parentheses.

ice rafting, and (c) an in-phase relationship between temperature as indicated by radiolarians and intensity of ice rafting. The last point may well indicate that the site is to the south of a glacial debris conjugate region (GDCR), analogous to the GDCR shown by Watkins et al. (1974), to exist in the Antarctic Ocean. Further, detailed work may show the existence and location of a GDCR in the North Atlantic area.
Paleomagnetism of Some Red Clays from Site 336, Leg 38; Implications for the Time of Subsidence of the Iceland-Faeroe Ridge (R.L.)

\section{Introduction}

Basaltic basement at Site 336 is covered by a rubble, which in turn is overlain by a section $(\sim 13 \mathrm{~m})$ of 


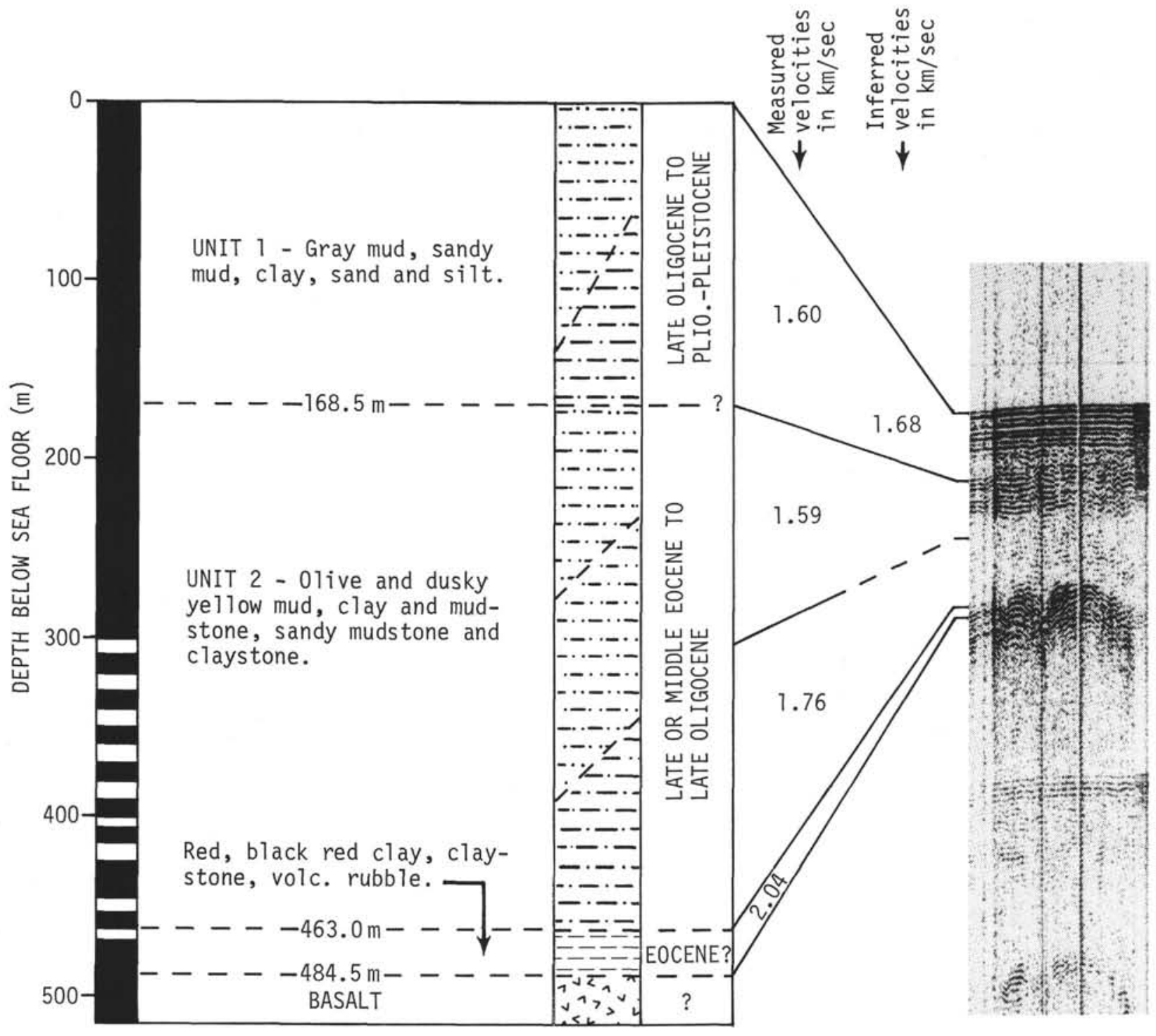

TOTAL PENETRATION 515.0 meters

Figure 5. Lithologic column and seismic profile, Site 336.

claystones. Both rock types are probably derived from the basalt; the former by in situ weathering, the latter probably by erosion and redeposition. The presence of hematite/ironoxyhydroxides in the clay reflected by the red color suggests oxidation either prior to, or associated with redeposition in shallow, oxygen-rich waters. The clay section may thus have acquired remanent magnetizations of depositional (DRM) and/or chemical (CRM) origin during the initial phase of submergence of the Iceland-Faeroe Ridge. A postulated shift of the geomagnetic field axis occurring in midTertiary times (Storetvedt, 1972; L $\phi v$ vlie and Kvingedal, 1975), corresponding to steepening of the paleomagnetic inclination, from around $55^{\circ}$ to $76^{\circ}$ at the latitude concerned, would thus allow an independent determination of the time of submergence of the Iceland-Faeroe Ridge.

\section{Sample Preparation}

Seven vertically oriented 10 -cc cylindrical samples were cut into two discs (A and B) approximately $1 \times$
$2.5 \mathrm{~cm}$. A discs were molded in a plastic resin, and the B discs were molded into cubes $(2.5 \times 2.5 \mathrm{~cm})$ of nonmagnetic plaster of Paris in order to sustain thermal treatment. The latter preparation was partly unsuccessful as specimens $5 \mathrm{~B}$ and $6 \mathrm{~B}$ disintegrated into small pieces during drying of the plaster. Stratigraphic positions of the samples investigated are presented in Table 4.

\section{Demagnetization Experiments}

Immediately after preparation of the A discs, the natural remanent magnetization (NRM), as well as the bulk magnetic susceptibility $(K)$, were measured on a 5cps spinner and a commercial AC-bridge, respectively. After storage in a field-free $(\sim 10 \gamma)$ space for 3 days, the seven A-specimens were remeasured. Changes in both the intensity and direction of the NRM were observed, reflecting the presence of viscous magnetic components. The NRM intensities, $K, Q^{\prime} \quad(=\mathrm{NRM} / K)$ and percentage change of NRM after storage are presented in Table 4. 


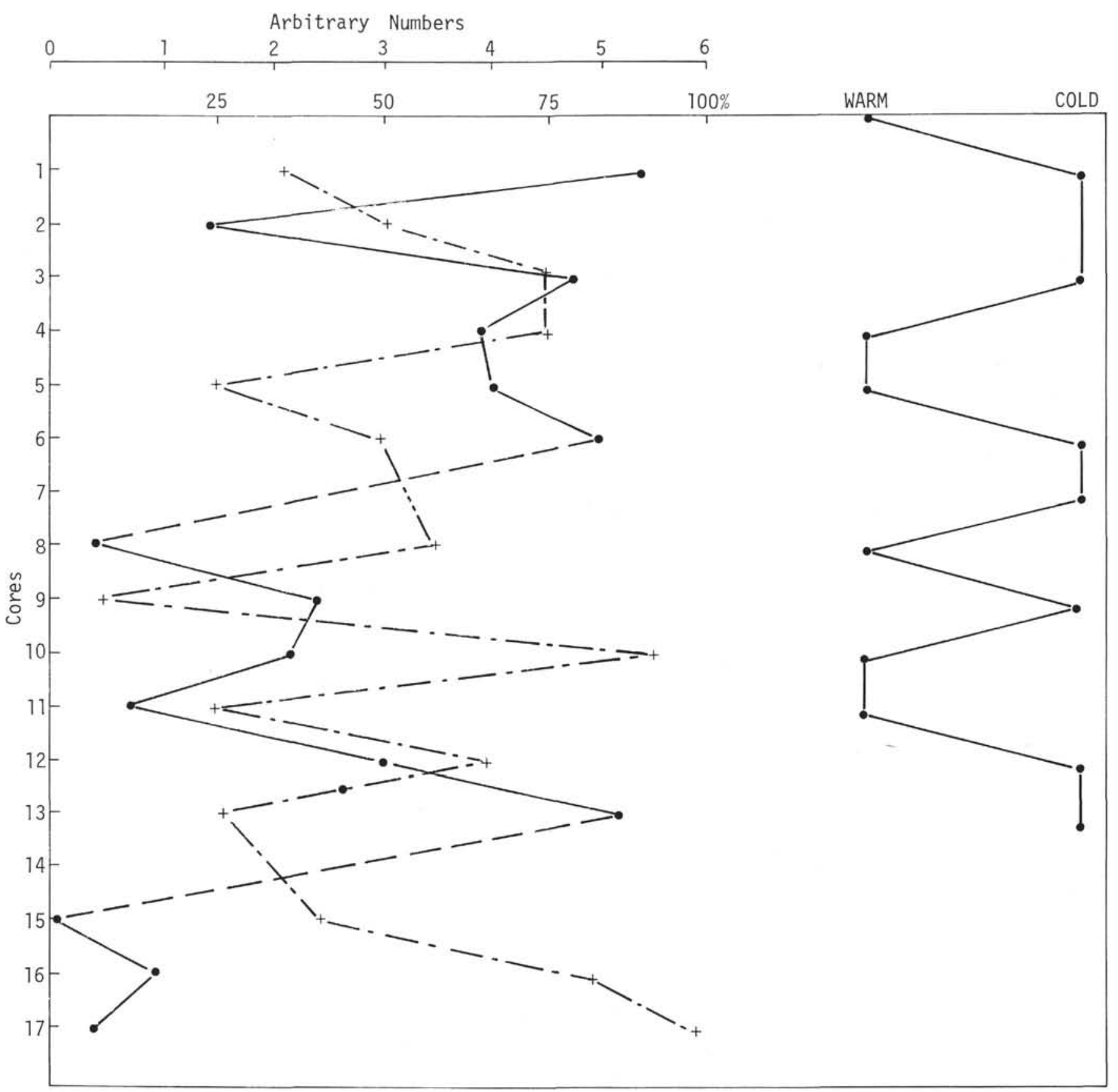

Figure 6. Distribution of coarse-grained fraction in core catchers from Site 336. Solid line: percentage of quartz (and feldspar) grains in $44 \mu \mathrm{m}$ fraction. Dash-dot line: total coarse-grained fraction, in arbitrary units, dash line: no samples. Climate variations as indicated by radiolarians are shown to the right.

Progressive alternating field (AF) demagnetization of the $\mathrm{A}$ discs in $30-50$ oe steps revealed the presence of rather soft magnetizations in all samples except in $4 \mathrm{~A}$. Median destruction fields (MDF; 50\% decrease of NRM) range between 50 and 220 oe (Table 4). AF demagnetization was limited by the appearance of viscous components above 200 oe. AF demagnetization curves are shown in Figure 7.

The directional behavior upon AF demagnetization shown in Figure 8 suggests the presence of unstable components. The more resistant part of the remanence, however, has upward pointing inclinations mostly ranging between about $-50^{\circ}$ and $-85^{\circ}$. The generally poorly defined paleomagnetic directions may be attributed to the appearance of viscous components during the demagnetization treatment.

Stepwise thermal demagnetization (B specimens) in a $10 \gamma$ residual field was only partly successful, as the clay initiated a drying out and disintegration process between $300^{\circ}$ and $400^{\circ} \mathrm{C}$.

The obtained thermal demagnetization curves shown in Figure 9(A), however, suggest a dominant blocking temperature spectrum between $100^{\circ} \mathrm{C}$ and $350^{\circ} \mathrm{C}$ for specimens $\mathrm{IB}$ and $2 \mathrm{~B}$, but extending beyond $400^{\circ} \mathrm{C}$ for samples $3 \mathrm{~B}$ and $7 \mathrm{~B}$. While samples $1 \mathrm{~B}$ and $2 \mathrm{~B}$ show continuous directional trends, the last two steps 
TABLE 4

Sample Location and Bulk Magnetic Properties

\begin{tabular}{|c|c|c|c|c|c|c|c|c|}
\hline $\begin{array}{c}\text { Sample } \\
\text { (Interval in } \mathrm{cm} \text { ) }\end{array}$ & $\begin{array}{l}\text { Sample } \\
\text { No. }\end{array}$ & $\begin{array}{c}\text { NRM } \\
\left(10^{-4} \text { emu/cc) }\right.\end{array}$ & $\begin{array}{c}K \\
\left(10^{-4}\right)\end{array}$ & $Q_{n}^{\prime}$ & $\begin{array}{c}\triangle \mathrm{NRM} \\
(\%)\end{array}$ & $\begin{array}{l}\text { MFD } \\
(\mathrm{oe})\end{array}$ & $\underset{(\mathrm{emu} / \mathrm{g})}{J_{S O}}$ & $\begin{array}{l}{ }^{\mathrm{T}} \mathrm{C} \\
\left.{ }^{\circ} \mathrm{C}\right)\end{array}$ \\
\hline \multirow[t]{2}{*}{$38-1,147-149$} & $1 \mathrm{~A}$ & 2.67 & 3.15 & 0.85 & -41 & 60 & \multirow{2}{*}{0.21} & \multirow{2}{*}{610} \\
\hline & 1B & 1.25 & 4.74 & 0.26 & & & & \\
\hline \multirow[t]{2}{*}{$39-1,76-78$} & $2 \mathrm{~A}$ & 2.55 & 2.84 & 0.90 & -11 & 50 & \multirow{2}{*}{0.04} & \multirow{2}{*}{-} \\
\hline & $2 \mathrm{~B}$ & 0.50 & 1.10 & 0.46 & & & & \\
\hline \multirow[t]{2}{*}{$39-1,116-118$} & $3 \mathrm{~A}$ & 0.60 & 0.67 & 0.90 & -1 & 90 & \multirow{2}{*}{0.02} & \multirow{2}{*}{-} \\
\hline & 3B & 0.14 & 0.65 & 0.21 & & & & \\
\hline \multirow[t]{2}{*}{$39-2,4-6$} & $4 \mathrm{~A}$ & 0.10 & 0.33 & 0.30 & -8 & $?$ & \multirow{2}{*}{0.03} & - \\
\hline & $\begin{array}{l}4 \mathrm{~B} \\
5 \mathrm{~A}\end{array}$ & $\begin{array}{l}0.64 \\
0.60\end{array}$ & $\begin{array}{l}1.57 \\
1.80\end{array}$ & $\begin{array}{l}0.41 \\
0.34\end{array}$ & +19 & 220 & & \multirow{2}{*}{600} \\
\hline $39-2,86-88$ & $\begin{array}{l}5 \mathrm{~A} \\
5 \mathrm{~B}\end{array}$ & ${ }_{-}^{0.00}$ & 1.00 & $\begin{array}{c}0.24 \\
-\end{array}$ & & & 0.11 & \\
\hline \multirow[t]{2}{*}{$39-2,140-142$} & $6 \mathrm{~A}$ & 1.62 & 1.22 & 1.33 & +6 & 100 & \multirow{2}{*}{0.07} & \multirow{2}{*}{620} \\
\hline & $6 \mathrm{~B}$ & - & - & - & & & & \\
\hline \multirow{2}{*}{$39-3,41-43$} & $7 \mathrm{~A}$ & 3.67 & 3.35 & 1.10 & -10 & 210 & \multirow{2}{*}{0.21} & \multirow{2}{*}{620} \\
\hline & $7 B$ & 4.89 & 2.75 & 1.78 & & & & \\
\hline
\end{tabular}

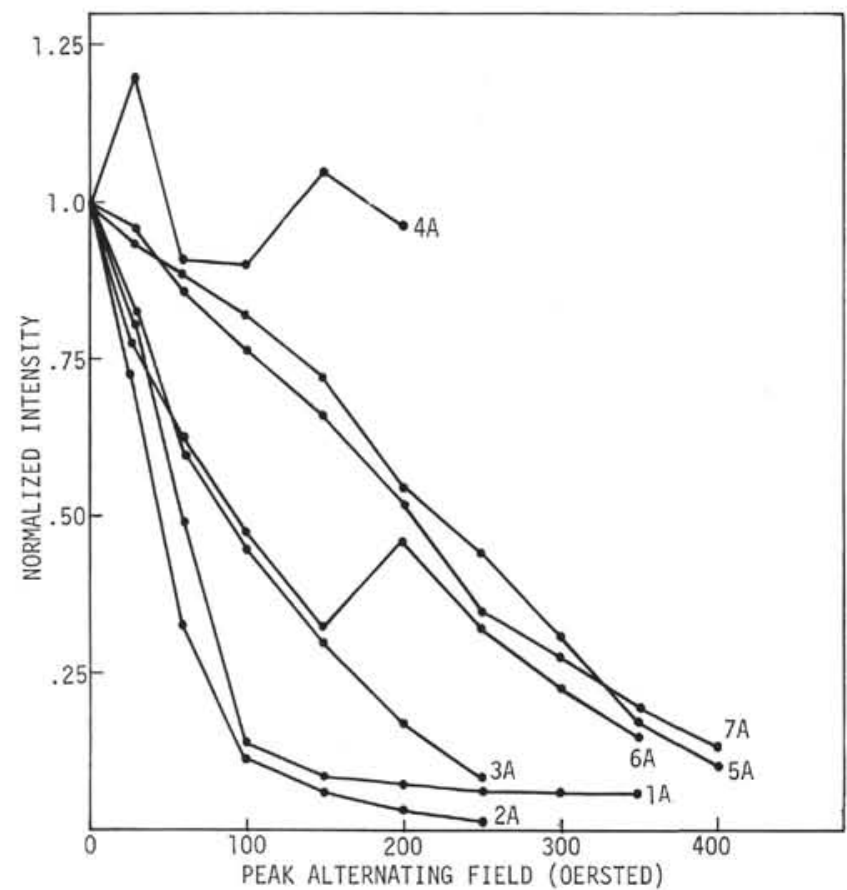

Figure 7. AF-demagnetization curves of NRM.
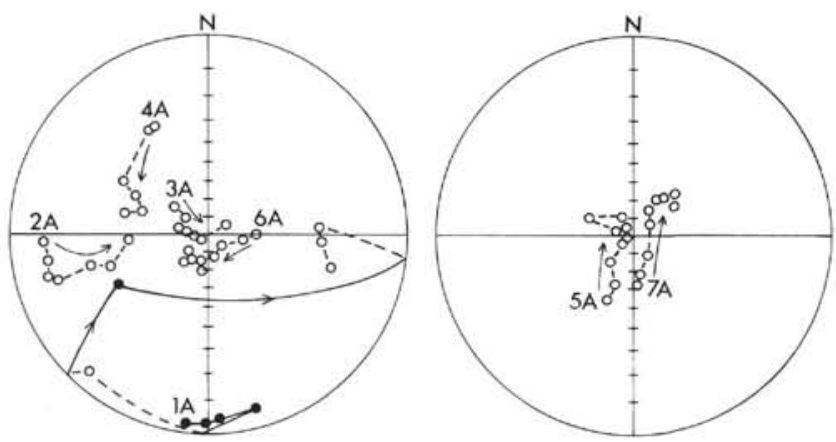

Figure 8. Stereographic projection of NRM directions dur. ing AF-demagnetization. Arbitrary azimuthal orientation.

appearing with negative inclinations (Figure 9[B]), specimens $3 \mathrm{~B}$ and $7 \mathrm{~B}$ define stable, reversed directions with inclination around $-70^{\circ}$. The latter specimen reveals a remarkable stable magnetization.

\section{Thermomagnetic Analysis}

The saturation magnetization at room temperature $\left(J_{s o}\right)$ and thermomagnetic curves $\left(J_{s}-T\right)$ were obtained by a calibrated, automatic recording, horizontal beam balance. Heating $\left(10^{\circ}-20^{\circ} / \mathrm{min}\right)$ of $50-200 \mathrm{mg}$ samples was performed in air to $700^{\circ} \mathrm{C}$ in magnetic fields ranging between 5-6.7 koe. Samples 1, 5, 6, and 7 were characterized by $J_{s o}$ values ranging between 0.07 and $0.21 \mathrm{emu} / \mathrm{g}$ (Table 4), and linear $J_{s}$-T curves defining initial Curie temperatures $\left(\mathrm{T}_{\mathrm{c}}\right)$ between $600^{\circ}$ and $620^{\circ} \mathrm{C}$ which decreases to $580^{\circ} \mathrm{C}$ during cooling (Figure 10a). Similar $J_{s}-T$ curves have been frequently encountered in red, highly oxidized interbasaltic tuff horizons from the Faeroe Islands, the Canary Islands, and Iceland (L $\phi$ vlie and Kvingedal, 1975; L $\phi$ vlie, 1975; L $\phi$ vlie, in preparation). The magnetic mineral(s) responsible for this type of curves are still unknown, but the high bulk oxidation states of these rocks $\left(\mathrm{Fe} \mathrm{O}_{3} / \mathrm{FeO}+\mathrm{Fe}_{2} \mathrm{O}_{3}>0.8\right)$ derived from basaltic source material tentatively suggest the presence of highly oxidized titanomaghemites. These break down upon heating above $650^{\circ} \mathrm{C}$ to almost pure magnetite $\left(\mathrm{T}_{\mathrm{c}}=\right.$ $580^{\circ} \mathrm{C}$ ), and possibly hematite.

Samples 2, 3, and 4 have significantly lower $J_{s o}$ $(0.02-0.04 \mathrm{emu} / \mathrm{g})$ and the hyperbolic $J_{s}-T$ curves do not define any $\mathrm{T}_{\mathrm{c}}$. By subtracting the theoretical paramagnetic magnetization (Collinson, 1968), however, a slightly concave heating curve appears which may indicate a $T_{c}$ between $560^{\circ}$ and $580^{\circ}$, reflecting the presence of a small amount of magnetite (Figure 10[B]). The Curie point of pure hematite $\left(670^{\circ} \mathrm{C}\right)$ has not been observed.

\section{Coercivity Analysis}

The A discs were subjected to increasing magnetic fields (maximum $7.5 \mathrm{koe}$ ), and the obtained isothermal remanence curves (IRM-H) are shown in Figure 11. While saturation IRM (SIRM) for samples $1 \mathrm{~A}, 5 \mathrm{~A}$, and $7 \mathrm{~A}$ is reached below $2.5 \mathrm{koe}$, indicative of low coercivity minerals such as magnetite or maghemite (Dunlop, 1972), the IRM-H features of samples $2 \mathrm{~A}, 3 \mathrm{~A}$, and $6 \mathrm{~A}$ indicate the presence of varying amounts of both 

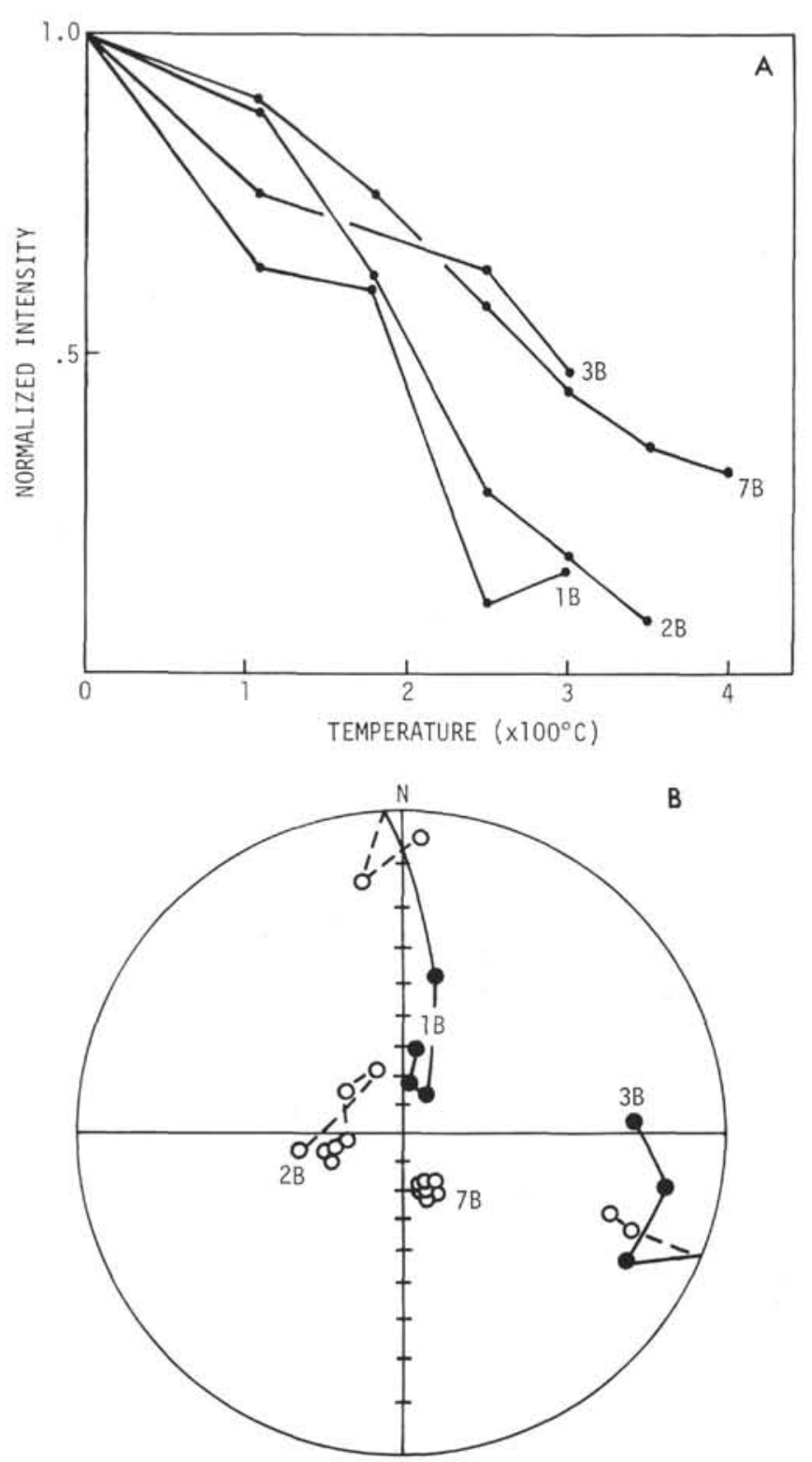

Figure 9. (A) Thermal demagnetization curves of NRM, (B) stereographic projection of NRM directions during thermal demagnetization. Arbitrary azimuthal orientation.

low and high coercivity minerals. As an SIRM is not reached in a 7.5 koe field, the high coercivity is probably caused by hematite pigment (Dunlop, 1972). Sample $4 \mathrm{~A}$ is completely dominated by high coercivity minerals.

AF demagnitization to 600 oe of the IRM $\mathrm{M}_{7.5}$ koe confirms the interpretation of the IRM-H curves (Figure 12). The IRM of samples containing hematite pigment are reduced by less than $50 \%$ as opposed to the low coercivity dominated samples which are reduced by more than $70 \%$ after alternating field treatment in 600 oe.

The normalized AF demagnetization curves of the NRM and IRM ${ }_{7.5 \text { koe intensities, respectively, reveal }}$ almost coinciding intensity curves for the low coercivity samples. This suggests remanence carrying titanomaghemites in the pseudo-single to multidomain states

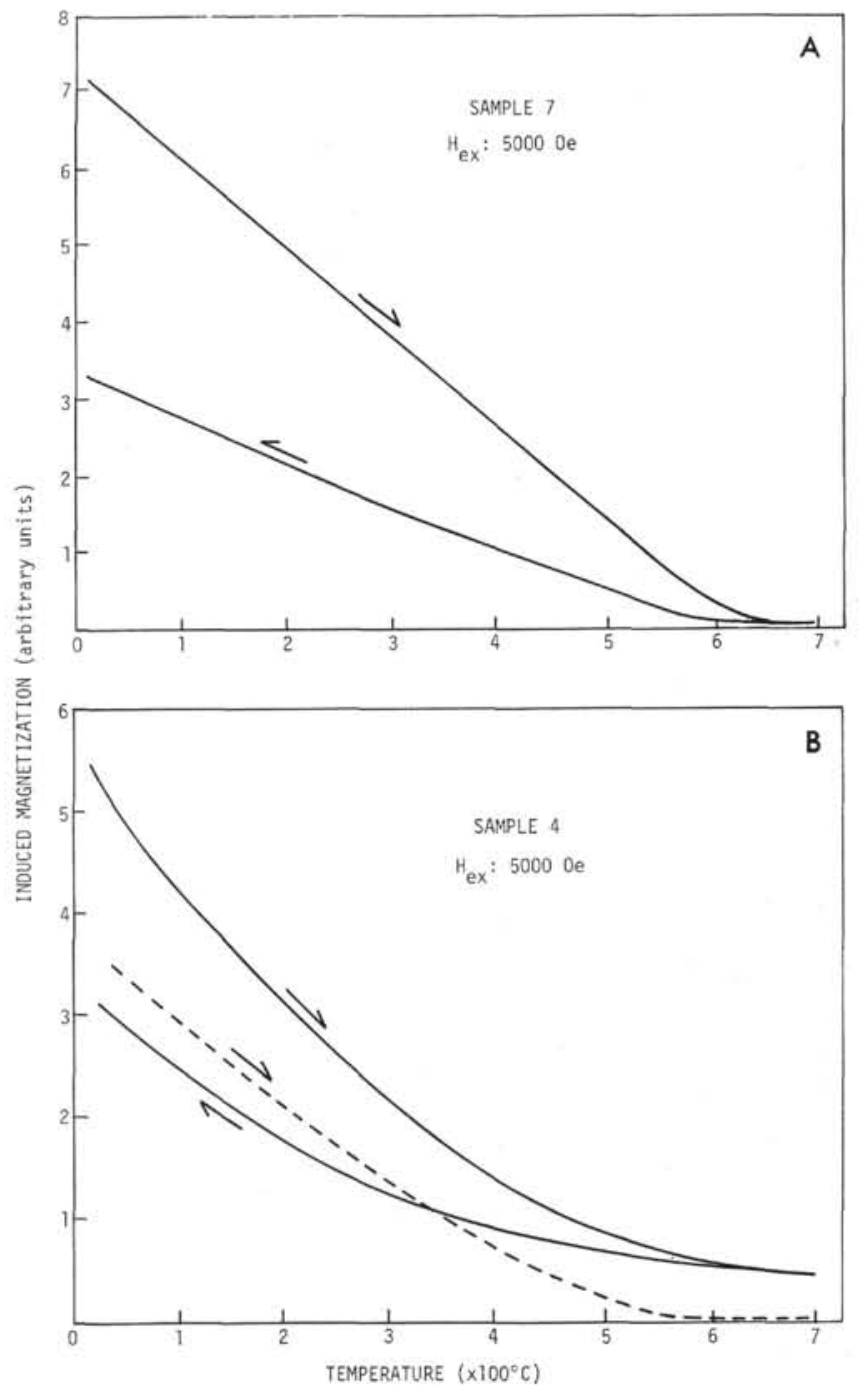

Figure 10. Characteristic thermomagnetic curves: $(A)$ samples $1,5,6$, and 7 with well-defined $T_{c},(B)$ samples 2, 3, and 4 , broken line theoretical paramagnetic magnetization subtracted from the heating curve.

(Lowrie and Fuller, 1971; Johnson et al., 1975). The demagnetization features of samples containing hematite pigment in conjunction with the IRM-H results suggest that the hematite present does not contribute to the stable remanent magnetization. It is tentatively suggested that the hematite pigment may be in a superparamagnetic to single-domain state and carrying the observed viscous magnetization (Creer, 1961).

Low-temperature variation of IRM 7.5 koe between room temperature and $-196^{\circ} \mathrm{C}$ in zero field did not reveal any unambiguously determined magnetic transition temperatures. A small steady increase in IRM with decreasing temperatures was observed for all samples, except sample 7 which shows indications of a $-150^{\circ} \mathrm{C}$ transition, indicative of magnetite.

\section{Discussion and Conclusion}

Demagnetization experiments suggest the presence of steep, upward dipping, stable paleomagnetic directions 


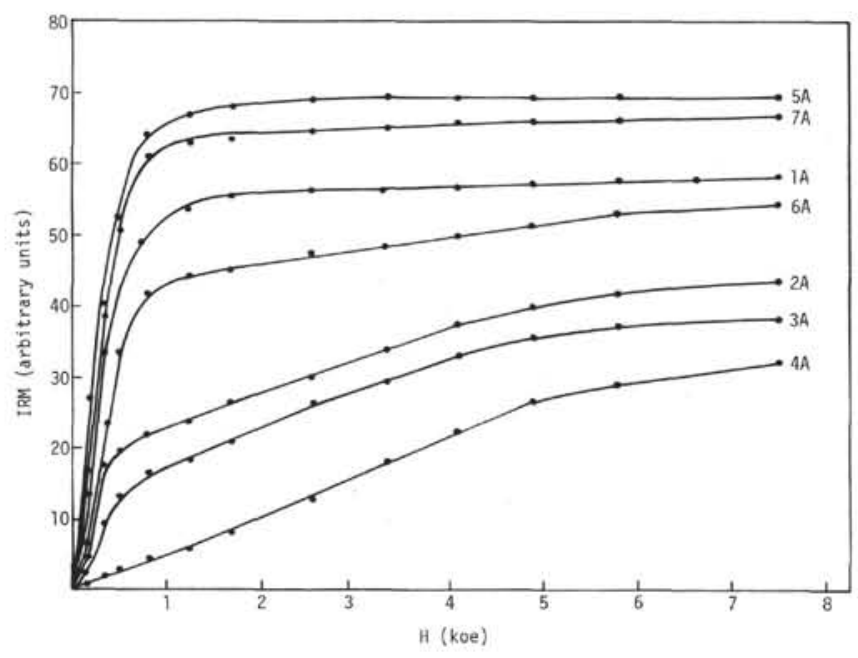

Figure 11. Isothermal remanence curves.

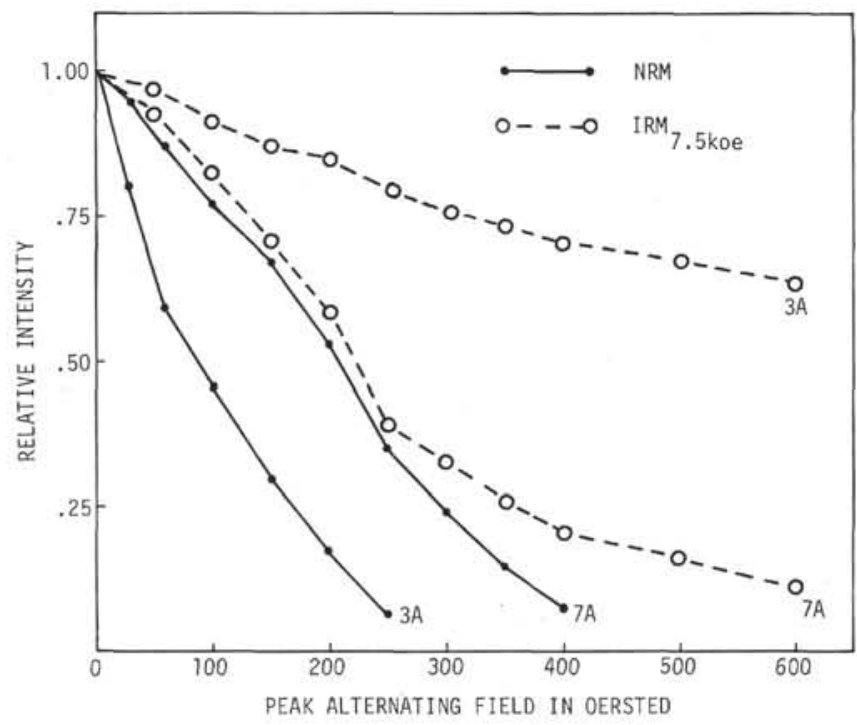

Figure 12. Typical examples of normalized AF-demagnetization curves of NRM and IRM $7.5 \mathrm{koe}$.

in five of the seven samples. The inclinations, which, for successfully demagnetized specimens are grouped around $70^{\circ}$, are compatible with the present geomagnetic field inclination at the latitude concerned. The presence of hematite-pigment and highly oxidized titanomaghemites (?) reflects extensive oxidation of the basaltic derived clay. Hematite does not seem to contribute to the stable NRM, leaving titanomaghemites (magnetite ?) as the major carrier of the remanent magnetization. The relatively low NRM intensities, along with low $Q_{n}$ values, are compatible both with a depositional as well as with a chemically induced remanent magnetization. The low stability against $\mathrm{AF}$ demagnetization, however, favors a DRM, as a CRM is likely to be magnetically harder (Johnson and Merrill, 1973). The lack of significant amounts of hematite pigment in three of the samples suggests predepositional oxidation of the clay. The magnetic age of the stable NRM is thus tentatively concluded to be contemporaneous with the early stage of submergence of the Iceland-Faeroe Ridge which occurred in middle Ter- tiary times; postdating the inferred shift of the geomagnetic field axis at about the Eocene/Oligocene boundary.

The micropaleontological derived middle or late Eocene age of the marine sediments overlying the claystones, however, suggests subsidence of Site 336 at a slightly earlier age than the paleomagnetic inferred age. If the overlying sediments are of middle or late Eocene age and the shift of the geomagnetic field axis occurred around the Eocene/Oligocene boundary, the discrepancy between the suggested ages of subsidence implies the presence of a postdepositional magnetization in the investigated clay.

\section{LITHOLOGY, SITE 352}

Two holes were drilled at Site 352 . Hole 352 achieved a penetration of 103.5 meters, and Hole $352 \mathrm{~A}$, a penetration of 122.5 meters. The sediment sequence is subdivided into two units. The 27.6 meters of sediment recovered in Hole 352 represent Unit 1 which was not recovered in Hole $352 \mathrm{~A}$. Unit 2 was present only in Hole 352A (Table 5, Figure 13).

\section{Unit Descriptions}

Although six cores were taken from Hole 352 , only Cores 1 through 4 are considered to contain in situ sediments. Core 5 contains sediments accumulated from downhole contamination of material higher in the section. This could very probably represent material between 18 and 27.5 meters. Core 3 , taken between these depths, had a minimal $(20 \mathrm{cc})$ recovery of unconsolidated sand and gravel, which could have sloughed into the hole.

Sample 6, CC contained two large basalt cobbles ( 5 and $10 \mathrm{~cm})$, small $(1 \mathrm{~cm})$ chert fragments, and fragments of Oligocene nannofossil chalk. Oligocene nannofossil chalk and ooze were the only sediments cored in Hole 352A, starting at 94 meters. It is possible that this sediment type was cored in Hole 352 (Sample $6, \mathrm{CC})$ beginning at 54.5 meters. Driller information reveals that the interval below 54.5 meters in Hole 352 exhibited different drilling characteristics, similar to those noted in Unit 2 of Hole 352A. On this basis, the base of Unit 1 in Hole 352 is established at 54.5 meters. The basalt cobbles may represent downhole contamination. A similar, but smaller, basalt pebble was found in the nannofossil oozes of Core 2, Section 1 of Hole $352 \mathrm{~A}$, also indicating downhole sloughing.

\section{Unit 1}

Unit 1, from Hole 352, consists of massive muds and sandy muds. Characteristically, Unit 1 contains angular to subangular basalt pebbles, and minor volcanic sandstone pebbles (up to $6 \mathrm{~cm}$ in diameter) in Cores 1 and 4 , and intermixed mud and volcanic ash in Cores 2 and 4 . The pebbles are scattered through the cores, as well as being concentrated in zones. It is not known whether this concentration represents a drilling artifact. Other lithologic features include: shell debris in Core 1, nannofossil ooze in Core 2 (Sample 2-3, 20-55 cm), foraminiferal sand in Core 2 (a vertical band at 100-110 $\mathrm{cm})$, and very thinly stratified $(1-5 \mathrm{~cm})$ volcanic ash in Core 4. Intense and moderate deformation is present, 
TABLE 5

Lithologic Units, Holes 352 and $352 \mathrm{~A}$

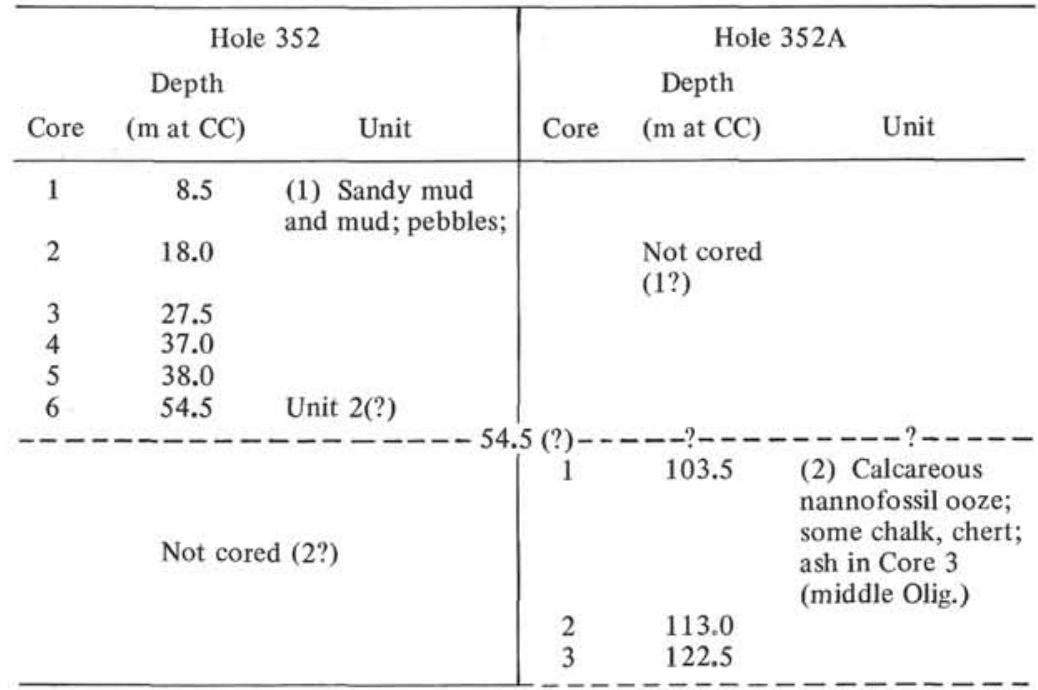

with color mottling and intermixing increasing with increased deformation.

The sandy muds contain $36 \%-70 \%$ sand, averaging $53 \%$. Correspondingly the muds have a decreased sand content, with a relative increase in silt or clay. Compositionally, the muds and sandy muds do not differ greatly, being dominantly composed of quartz, feldspar, and clay minerals, with varying amounts $(0 \%$ $20 \%$ ) of accessory minerals, siliceous and calcareous microfossils, volcanic ash, palagonite (?), fecal pellets, and lithic fragments. The $\mathrm{CaCO}_{3}$ content averages $8 \%$, showing a tendency to decrease with depth. This is in spite of the assumption that the Unit 2 boundary lies at 54.5 meters. However, the last $\mathrm{CaCO}_{3}$ sample was taken at 39 meters.

\section{Unit 2}

Unit 2 is a calcareous nannofossil ooze, with localized chalk zones and chert fragments. In Cores 1 and 2, the dominant color is light bluish-gray with greenish hues. The colors darken somewhat in Core 3, to greenish-black, greenish-gray, and dark greenishgray reflecting volcanic ash, palagonite, and chlorite. Color mottling is noticeable in all cores, becoming prevalent in Core 3 due to extensive bioturbation.

Compositionally, the nannofossil ooze content varies considerably from Core 1 to Core 3 . In Cores 1 and 2, nannofossils average $40 \%-55 \%$, with $10 \%-20 \%$ sponge spicules, $10 \%-15 \%$ clay minerals, and $3 \%-10 \%$ foraminifera. Other accessory components include quartz, feldspar, mica, opaques, volcanic glass, fecal pellets, and chlorite. In Core 3 , the nannofossil content ranges from $25 \%$ to $50 \%$, the sponge spicule content is $10 \%$ to $25 \%$ in Section 1, decreasing to $5 \%-10 \%$ in Section 2; volcanic ash becomes an important constituent in Core 3, Section $1(10 \%-15 \%)$, as do clay minerals $(20 \%-30 \%)$. Grain size analyses indicate muds, with an average of $17 \%$ sand and $40 \%$ silt. $\mathrm{CaCO}_{3}$ averages $51 \%$

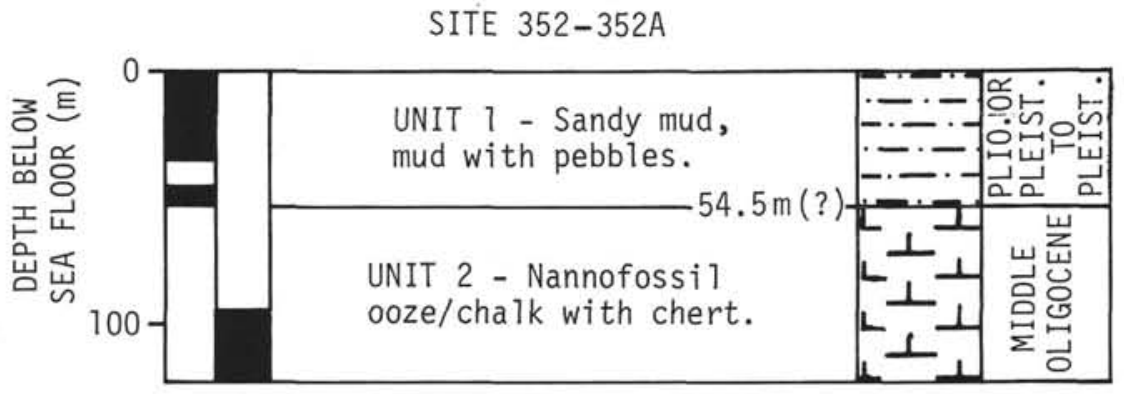

TOTAL PENETRATION 352: 103.5 meters

TOTAL PENETRATION 352A: 122.5 meters

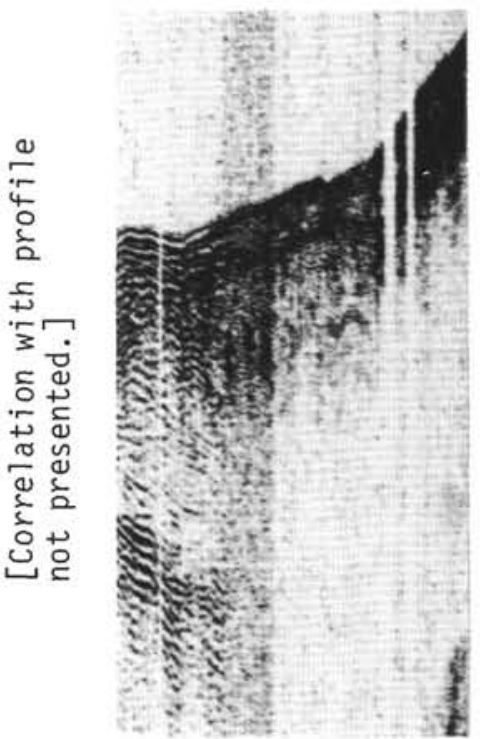

Figure 13. Lithologic column and seismic profile - Site 352. 
for three samples, reflecting the calcareous microfossil content.

\section{Interpretations}

Because of the limited depth penetrated by both holes, interpretations are, in turn, limited.

1) The nannofossil ooze (Unit 2) indicates dominant biogenic pelagic sedimentation during middle-late(?) Oligocene time. Associated foraminifera indicate bathyal depths. A short period of volcanic activity in the area (Iceland) is indicated by the ash and palagonite of Core 3, Section 2. Extensive bioturbation in Core 3, Section 2, and to some degree in Core 3, Section 1 indicates a bottom environment and a sedimentation rate conducive to bottom dwelling organisms.

A comparison to Site 336 shows that Unit 2 of Hole $352 \mathrm{~A}$ is correlative in time to the upper part of Unit 2 for Site 336. In the latter hole, however, the sediments are mudstone, with siliceous biogenic (radiolarians, diatoms, and sponge spicules) material. Clearly the Iceland-Faeroe Ridge in middle-late Oligocene times was an effective barrier to water exchange and permitted distinctive and contrasting biogenic pelagic environments to be maintained; calcareous and siliceous to the south, siliceous (dominately) to the north.

The limited middle Oligocene calcareous section in Hole $352 \mathrm{~A}$ seems to substantiate that the IcelandFaeroe Ridge remained an effective barrier to North Atlantic waters despite submergence due to a shift of the spreading axis to Iceland, until 25-20 m.y. (upper Oligocene-early Miocene).

2) A probable late(?) Oligocene to Pleistocene hiatus is indicated from the cores of Holes 352 and 352A. An assumption here is that the 54.5-94.0 meter depth does contain the boundary between Units 1 and 2 . However, it is not at all possible to determine whether the missing interval is represented by: (a) a condensed sequence, (b) nondeposition, or (c) deposition, subsequent erosion. In any case, it is also not clear whether the interval involves the Miocene, the Pliocene, or both. Alternatively, it may be possible that coring gaps in Holes 352 and $352 \mathrm{~A}$ may contain a portion of this missing interval.

A late Oligocene to Pliocene unconformity at Site 336 also presented a similar set of explanations as to its cause. However, its existence at both sites may be due to continued submergence of the ridge (post $22.5 \mathrm{~m} . \mathrm{y}$.), whereby increased flow of bottom water may have eroded Miocene-Pliocene sediments, or prevented deposition.

3) Unit 1, the dominant sandy muds and muds, admixed with coarse pebbles represents pelagic sedimentation of terrigenous components, with contributions from ice rafting. This unit is a great deal thinner $(38[?] \mathrm{m})$ than a corresponding unit found at Site 336 $(168.5 \mathrm{~m})$. However, it may be that bottom currents or other transfer mechanisms were more effective on the southern flank of the ridge (352) during Miocene or Pliocene and subsequently removed a large part of section or prevented deposition. Sediment thickness profiles across the Iceland-Faeroe Ridge presently show a marked asymmetry of sediment distribution, the sediment cover being much thicker and continuous on the northfacing slope (Jones et al., 1970; Eldholm and Windisch, 1974). Alternatively, surface current patterns during "glacial" time may have controlled transfer of terrigenous material and its subsequent deposition on the northern or southern flank.

\section{IGNEOUS PETROGRAPHY-PETROLOGY - GEOCHEMISTRY, SITE 336}

\section{Megascopic Description}

Cores 41-44 contained slightly weathered volcanic rocks and the following magmatic rocks: fine-grained basalts black (N 1) to olive-green (5 G 3/2), diabase basalts, and amygdaloidal basalts with veins and fissures filled by white calcite and dark green chlorite. There is a scattering of pyrite in veins. Some intervals (Samples 42-1, 33-39 cm, 139-143 cm, 43-1, 135-150 cm, $44-2,0-15 \mathrm{~cm})$ are brecciated and mylontized. Slickensides with gliding marks are present. The amygdules and vesicles have an oval form $(0.5$ to $0.8 \mathrm{~cm})$ and are often present in the lower part of the hole (Core 44). The center of the amygdule is white calcite, the remainder dark-green chlorite.

\section{Petrographic Descriptions}

A study of 17 thin sections taken from a profile of the volcanogenic strata shows that the composition is homogeneous. Textural and structural features, however, change along the profile. In the upper portions (Cores 41, 42, 43), fine-grained basalts and diabase basalts prevail. In the lower portion (Core 44), amygdaloidal basalts are present.

The fine-grained basalts have microporphyritic textures, while the groundmass texture is microintersertal. The mineral composition is: plagioclase $(35 \%-40 \%)$, clinopyroxene (35\%-50\%), magnetite (10\%-12\%), altered volcanic glass $(5 \%-10 \%)$. Secondary minerals are chlorite, hydrobiotite, goethite, and calcite (all up to $10 \%)$.

The amount of microphenocrysts is small (8\%-12\%), their arrangement irregular. Microphenocrysts consist of grains of plagioclase, clinopyroxene, and rare olivine. The size of plagioclase grains is $0.4-1.0 \mathrm{~mm}$; their form is oblong to prismatic. There is zoning in some grains, and their central parts are replaced by chlorite aggregates. The grains are polysynthetically twinned. The plagioclase is labradorite (An 55-60), having a maximum extinction angle $\left(30^{\circ}-36^{\circ}\right)$ in the zone for albite twins $(\perp 010)$. Clinopyroxene phenocrysts (0.2-0.3 mm) are less idiomorphic compared with the plagioclase. They are irregular prismatic grains with poor cleavage. Idiomorphic olivine phenocrysts replaced by goethite are rarely present.

In the groundmass, there is plagioclase crystallization from microimpregnations, to finer laths and microlites with a gradual decrease of size and degree of idiomorphism. Laths $(0.2 \times 0.04 \mathrm{~mm})$ are relatively idiomorphic and twinned. Their orientation is random, and in some parts subparallel with weakly defined microflows. Irregular grains of clinopyroxene (0.05-0.8 $\mathrm{mm}$ ) are arranged between microlites and plagioclase laths of the groundmass. Magnetite forms impregnations (up to $0.1 \mathrm{~mm}$ ), underdeveloped skeletal grains, 
and grain aggregates. Glass is replaced by chlorite aggregates.

The diabase basalts have a porphyritic texture, and the texture of the groundmass is microintersertal and diabasic. The structure of some areas is amygdaloidal. The composition is: plagioclase $(35 \%-40 \%)$, clinopyroxene $(40 \%-45 \%)$, magnetite $(8 \%-12 \%)$, altered volcanic glass $(10 \%-15 \%)$. Secondary minerals are chlorite, hydrobiotite, goethite, and calcite. The phenocrysts (10\%-15\%) are irregularly arranged, and consist of plagioclase and clinopyroxene. Plagioclase is idiomorphic, sometimes having well-developed terminations forming single grains (up to $1.2 \times 2.0 \mathrm{~mm}$ ), and glomero-intergrowths. Plagioclase phenocrysts $(336-43-1,123-126 \mathrm{~cm})$ have $\mathrm{Ng}(\gamma)=1.571, \mathrm{~Np}(\alpha)=$ 1.562 in accordance with labradorite (An 66-68). The central part of some phenocrysts is replaced by scales of chlorite aggregates. Pyroxene phenocrysts are less idiomorphic than plagioclase, forming irregular prisms with a length of $0.5 \mathrm{~mm}$.

The groundmass is fine grained and occasionally glassy. It consists of pyroxene, plagioclase, and magnetite. Plagioclase is idiomorphic, consisting of oblong-prismatic laths $(0.5-0.03 \mathrm{~mm})$ gradually transforming into finer microlites $(0.1-0.15 \mathrm{~mm})$. Laths form an intersertal lattice and sometimes microflows with parallel orientation. Gaps between them are filled with clinopyroxene $(\mathrm{Ng}[\gamma]=1.722, \mathrm{~Np}[\alpha]=1.695$ in Sample 43-1, 123-126 cm) associated with magnetite. Pyroxene forms separate grains (0.1-0.05 mm), and aggregates of an irregular shape. Glass is replaced by aggregates (scales) of yellow-green chlorite.

The composition and structure of the amygdaloidal basalt are similar to that of fine-grained basalt, but the amygdaloidal basalt contains a large amount $(10 \%)$ of round and oval amygdules consisting of calcite and chlorite.

\section{Summary}

The results of the petrographic study of the basalts, diabase basalts, and amygdaloidal basalts show that the rocks from Site 336 represent a thin sill or a thick lava stream. The high degree of alteration of the volcanic glass indicates an old age.

\section{Geochemistry of Basalts (H.R-F.J.E.)}

Basalts from Site 336, on the northern slope of the Iceland-Faeroe Ridge, show a medium degree of alteration, with $1.7 \%-3.4 \%$ total $\mathrm{H}_{2} \mathrm{O}$, and/or $100 \mathrm{FeO} / \mathrm{Fe}_{2} \mathrm{O}_{3}$ $+\mathrm{FeO}$ between $46 \%$ and $61 \%$. Exceptions are the samples from Core 44, where the high water content indicates a much higher degree of alteration; the latter samples were omitted from the Tables.

The element variations of samples of different cores within Site 336 are low (Table 6). Most major elements fit very well within the range of normal ocean floor basalts, as published by Cann, 1971 (Table 6). A low $\mathrm{Al}_{2} \mathrm{O}_{3}$ content (14.0\%-15.5\%) suggests the lack of extensive plagioclase accumulation. The average of some incompatible elements (Table 7) shows a very low content: $\mathrm{K}_{2} \mathrm{O}: 0.17 \%, \mathrm{Sr}: 128 \mathrm{ppm}, \mathrm{Zr}: 75 \mathrm{ppm}, \mathrm{Rb}:<5$ $\mathrm{ppm}$, all typical for mid-ocean ridge basalts.

Within the OL-HY-DI-Q-diagram the data are plotted in the field of quartz-tholeiite and olivine tholeiite, similar to mid-ocean-ridge type tholeiites.

\section{PHYSICAL PROPERTIES, SITE 336}

\section{Bulk Density, Porosity, and Water Content}

Bulk density (GRAPE and rock chip) and water content results show differences between sediments of different ages and types. Cores 1-13 exhibit fairly high bulk densities from 1.65 to $1.95 \mathrm{~g} / \mathrm{cc}$, with corresponding low water contents. These include clays, muds, and sandy muds of Pliocene and Plio-Pleistocene age. Drilling deformation may have contributed to the observed variability in bulk density.

Measurements on Cores 14-20 were limited due to poor recovery. Lower bulk densities and higher water contents $(1.42-1.55 \mathrm{~g} / \mathrm{cc} ; 45 \%-60 \%)$ reflect the lithologies, primarily mixed terrigenous mud and diatom, radiolarian, or siliceous ooze, with occasional volcanic ash.

Lithification becomes significant in Core 23 and continues to the base of the section above the basalt (Core 39). GRAPE bulk density values show considerable scatter, probably due to drilling brecciation. However, rock chip samples through the brecciated interval show a bulk density of $1.55 \mathrm{~g} / \mathrm{cc}$ and water content of $45 \%$, with little variation between Cores 23-30. A sharp increase in bulk density (average $1.75 \mathrm{~g} / \mathrm{cc}$ ) with a decrease in water content (average $35 \%$ ) is present in Core 31 and extends through Core 39. This unit corresponds to the middle or late Eocene. Table 8 presents some representative values for bulk density and porosity, derived from the corrected digital GRAPE records. The samples selected for this table were from the base of the core, or from a clearly undisturbed section.

\section{Shear Strength}

Shear strength of the cohesive sediments was measured with the "Torvane" shear device, equipped with an adaptor head which measured strengths to 0.2 TSF $(198.43 \mathrm{~g} / \mathrm{cc})$. In lithified sediments, the pocket penetrometer (Soil Test, Model CL-600) was used to measure the unconfined compressive strength. The maximum value obtained by this instrument is $4.5 \mathrm{TSF}$ $\left(4.46 \mathrm{~kg} / \mathrm{cm}^{2}\right)$. Unconfined compressive strength, $P_{\mathrm{c}}$, is related to shear strength, $\mathrm{c}$; by

$$
c=\frac{P_{C}}{2}(\text { Richards, 1962) }
$$

Normally, both instruments are used for measurements taken perpendicular to bedding. However, due to the nature of processing of the cores, all measurements were made in a homogeneous sediment which had been cut parallel to the long axis of the core. Thus, measurements of shear and unconfined compressive strength were made parallel to bedding. Use of the pocket penetrometer was discontinued when parting along bedding planes occurred.

Figure 14 shows the shear and unconfined compressive strength profile for Site 336. Values of shear strength plotted represent section averages. Shear strength increases regularly from 0.03 TSF (29.76 $\left.\mathrm{g} / \mathrm{cm}^{2}\right)$ in Core 1 to 0.1 TSF $\left(99.21 \mathrm{~g} / \mathrm{cm}^{2}\right)$ in Core 3, then varies through Cores 4-9. From Core 9 to 12, it ex- 
TABLE 6

Analyses of Site 336 Basalts

\begin{tabular}{|c|c|c|c|c|c|c|c|}
\hline & \multicolumn{3}{|c|}{ Core 41 , Section 1} & \multicolumn{3}{|c|}{ Core 42} & \multirow{2}{*}{$\begin{array}{l}\text { Core } 43 \\
\text { Section } 1 \\
123-126 \mathrm{~cm} \\
\text { RF } 9781 \\
\end{array}$} \\
\hline & $\begin{array}{c}14 \mathrm{~A} \\
\text { RF } 9776\end{array}$ & $\begin{array}{c}1 \mathrm{~A} \\
\text { RF } 9777\end{array}$ & $\begin{array}{l}36-37 \mathrm{~cm} \\
\text { RF } 9785\end{array}$ & $\begin{array}{c}1 \mathrm{~A} \\
\text { RF } 9778\end{array}$ & $\begin{array}{c}144-146 \mathrm{~cm} \\
\text { RF } 9779\end{array}$ & $\begin{array}{l}82-84 \mathrm{~cm} \\
\mathrm{RF} 9780\end{array}$ & \\
\hline $\mathrm{SiO}_{2}$ & 49.49 & 48.72 & 48.31 & 48.30 & 49.26 & 48.38 & 48.19 \\
\hline $\mathrm{TiO}_{2}^{2}$ & 1.20 & 1.32 & 1.03 & 1.37 & 1.25 & 1.37 & 0.99 \\
\hline $\mathrm{Al}_{2} \mathrm{O}_{3}$ & 14.70 & 13.98 & 14.66 & 14.88 & 1429 & 15.46 & 15.08 \\
\hline $\mathrm{Fe}_{2} \mathrm{O}_{3}$ & 5.79 & 5.58 & 4.67 & 6.51 & 6.47 & 4.30 & 5.30 \\
\hline $\mathrm{FeO}$ & 5.67 & 6.99 & 6.42 & 5.59 & 5.59 & 6.84 & 5.06 \\
\hline $\mathrm{MnO}$ & 0.17 & 0.20 & 0.17 & 0.15 & 0.18 & 0.14 & 0.18 \\
\hline $\mathrm{MgO}$ & 6.54 & 6.70 & 7.54 & 6.17 & 6.47 & 6.74 & 7.44 \\
\hline $\mathrm{CaO}$ & 11.20 & 11.00 & 11.66 & 11.30 & 10.87 & 9.43 & 11.56 \\
\hline $\mathrm{Na}_{2} \mathrm{O}$ & 2.45 & 2.40 & 2.17 & 2.34 & 2.36 & 2.65 & 2.06 \\
\hline $\mathrm{K}_{2} \mathrm{O}$ & 0.15 & 0.14 & 0.31 & 0.17 & 0.14 & 0.14 & 0.11 \\
\hline $\mathrm{H}_{2} \mathrm{O}_{\text {tot }}$ & 2.74 & 2.71 & 1.72 & 2.65 & 3.13 & 4.27 & 4.30 \\
\hline $\mathrm{SO}_{3}$ & 0.00 & 0.02 & 0.04 & 0.00 & 0.00 & 0.01 & 0.00 \\
\hline $\mathrm{P}_{2} \mathrm{O}_{5}$ & 0.10 & 0.08 & 0.08 & 0.11 & 0.10 & 0.10 & 0.07 \\
\hline $\mathrm{CO}_{2}$ & n.d. & n.d. & 0.09 & n.d. & n.d. & n.d. & n.d. \\
\hline Total & 100.20 & 99.84 & 98.87 & 99.54 & 100.11 & 99.83 & 100.34 \\
\hline \multicolumn{8}{|c|}{ C.I.P.W. Norms ${ }^{a}$} \\
\hline $\mathrm{Qz}$ & 1.63 & 0.75 & 0.00 & 1.12 & 2.23 & 1.23 & 0.81 \\
\hline Or & 0.91 & 0.85 & 1.89 & 1.04 & 0.86 & 0.87 & 0.68 \\
\hline $\mathrm{Ab}$ & 21.34 & 20.97 & 18.96 & 20.52 & 20.67 & 23.50 & 18.20 \\
\hline An & 29.51 & 27.84 & 30.30 & 30.67 & 28.97 & 21.31 & 32.97 \\
\hline $\mathrm{Di}$ & 22.10 & 22.96 & 23.55 & 21.89 & 21.47 & 13.88 & 21.49 \\
\hline Hy & 17.89 & 19.58 & 16.98 & 17.50 & 18.97 & 21.86 & 19.95 \\
\hline $\mathrm{Ol}$ & 0.00 & 0.00 & 2.24 & 0.00 & 0.00 & 0.00 & 0.00 \\
\hline Mt & 4.03 & 4.22 & 3.79 & 4.31 & 4.13 & 4.36 & 3.77 \\
\hline II & 2.35 & 2.59 & 2.02 & 2.69 & 2.46 & 2.73 & 1.96 \\
\hline $\mathrm{Ap}$ & 0.24 & 0.20 & 0.20 & 0.27 & 0.25 & 0.25 & 0.17 \\
\hline $\operatorname{Pr}$ & 0.00 & 0.04 & 0.08 & 0.00 & 0.00 & 0.02 & 0.00 \\
\hline \multicolumn{8}{|c|}{ Norm. Plag. An } \\
\hline & 58.03 & 57.04 & 61.51 & 59.91 & 58.36 & 57.12 & 64.43 \\
\hline \multicolumn{8}{|l|}{ Diff. Ind. } \\
\hline & 23.88 & 22.57 & 20.85 & 22.68 & 23.76 & 25.59 & 19.69 \\
\hline \multicolumn{8}{|c|}{ Norm. C.I. } \\
\hline & 46.61 & 49.59 & 48.84 & 46.67 & 47.28 & 43.10 & 47.34 \\
\hline
\end{tabular}

a Norms are based on analyses recalculated to $100 \% \mathrm{H}_{2} \mathrm{O}$ free with $\mathrm{Fe}_{2} \mathrm{O}_{3}$ standardized at $\% \mathrm{TiO}_{2}+1.5$ (Irvine and Baragar, 1971).

TABLE 7

Trace Elements of Site 336 Basalts (ppm)

\begin{tabular}{|c|c|c|c|c|c|c|c|}
\hline & $\begin{array}{c}\text { RF } \\
9776\end{array}$ & $\begin{array}{c}\text { RF } \\
9777\end{array}$ & $\begin{array}{c}\text { RF } \\
9785\end{array}$ & $\begin{array}{c}\text { RF } \\
9778\end{array}$ & $\begin{array}{c}\text { RF } \\
9779\end{array}$ & $\begin{array}{c}\text { RF } \\
9780\end{array}$ & $\begin{array}{c}\text { RF } \\
9781\end{array}$ \\
\hline $\mathrm{Sr}$ & 116 & 114 & 69 & 122 & 115 & 124 & 111 \\
\hline $\mathrm{Nb}$ & $<3$ & 5 & $<3$ & $<3$ & $<3$ & 3 & $<3$ \\
\hline $\mathrm{Zr}$ & 74 & 71 & 53 & 82 & 78 & 79 & 65 \\
\hline $\mathrm{Y}$ & 29 & 27 & 29 & 26 & 32 & 21 & 18 \\
\hline $\mathrm{Ni}$ & 66 & 71 & 163 & 59 & 69 & 71 & 102 \\
\hline Co & 50 & 57 & 51 & 47 & 53 & 59 & 47 \\
\hline V & 303 & 364 & 314 & 359 & 326 & 380 & 297 \\
\hline $\mathrm{Zn}$ & 113 & 113 & 97 & 91 & 97 & 104 & 94 \\
\hline $\mathrm{Cu}$ & 185 & 77 & 88 & 228 & 302 & 303 & 92 \\
\hline $\mathrm{Cr}$ & 60 & 55 & 437 & 59 & 57 & 54 & 293 \\
\hline $\mathrm{Ce}$ & 21 & 18 & 19 & 24 & 16 & 26 & 19 \\
\hline $\mathrm{Sc}$ & 52 & 54 & 52 & 60 & 53 & 58 & 54 \\
\hline
\end{tabular}

ceeds the limit of sensitivity of the apparatus $->0.2$ TSF $\left(198.43 \mathrm{~g} / \mathrm{cm}^{2}\right)$.

Below Core 19, lithification prevented the use of the "Torvane," and the pocket penetrometer was used. Un- confined compressive strength ranged between 2.8 and 4.5 TSF ( $2.78 \mathrm{kilo} / \mathrm{cm}^{2}$ to $\left.4.46 \mathrm{kilo} / \mathrm{cm}^{2}\right)$. Because of core deformation, remolding of the clay units may have occurred, and values of shear strength must be considered to be minimum.

It is difficult to assess the reliability of the data obtained by these techniques. In particular, the penetrometer may be affected by both operator error and lithologic variation. However, in the light of shipboard operations, core deformation, and time, it is believed that the data are valuable in that they provide order-ofmagnitude estimates heretofore unavailable.

\section{Sonic Velocity}

In general the section possesses sonic velocities averaging $1.60 \mathrm{~km} / \mathrm{sec}$, with occasionally lower (1.50) and higher (1.70) velocities found from the surface to Core 28 . Below Core 28 , velocities increase sharply to a maximum of $2.10 \mathrm{~km} / \mathrm{sec}$ in Core 36 . They remain between 1.9 and $2.1 \mathrm{~km} / \mathrm{sec}$ to the basalt in Core 39 , where they increase sharply. Table 9 gives means and 
TABLE 8

Bulk Density and Porosity Values, Site 336

\begin{tabular}{rrrrrrrr}
\hline Core & Section & $\begin{array}{c}\text { Depth } \\
(\mathrm{m})\end{array}$ & $\begin{array}{c}\text { Density } \\
(\mathrm{g} / \mathrm{cc})\end{array}$ & $\begin{array}{c}\text { Porosity } \\
(\%)\end{array}$ & Density & Porosity \\
\hline 1 & 5 & 6.8 & 1.870 & 47.99 & & & \\
5 & 6 & 44.0 & 1.647 & 61.71 & $x=1.826$ & 50.68 \\
8 & 2 & 65.9 & 1.589 & 65.31 & $s=0.205$ & 12.64 \\
9 & 3 & 77.0 & 1.789 & 52.97 & & & \\
10 & 2 & 94.3 & 1.899 & 46.19 & & & \\
10 & 2 & 95.2 & 2.163 & 29.94 & & & \\
18 & 2 & 199.0 & 1.534 & 68.10 & & & \\
18 & 5 & 103.7 & 1.395 & 77.26 & $x=$ & 1.558 & 67.18 \\
19 & 2 & 209.0 & 1.425 & 75.37 & $s=0.129$ & 8.00 \\
20 & 5 & 223.5 & 1.592 & 65.08 & & & \\
21 & 5 & 232.0 & 1.691 & 59.03 & & & \\
22 & 5 & 242.0 & 1.703 & 58.25 & & & \\
23 & 5 & 251.5 & 1.610 & 63.97 & & & \\
24 & 5 & 261.5 & 1.542 & 68.19 & $x=$ & 1.629 & 62.84 \\
25 & 6 & 272.0 & 1.570 & 66.45 & $s=0.073$ & 4.47 \\
26 & 5 & 280.5 & 1.667 & 60.51 & & & \\
27 & 6 & 291.5 & 1.638 & 52.25 & & & \\
30 & 5 & 337.5 & 1.745 & 55.67 & & & \\
31 & 3 & 353.2 & 1.744 & 55.77 & $x=$ & 1.716 & 57.40 \\
33 & 5 & 394.0 & 1.795 & 52.64 & $s=$ & 0.096 & 5.90 \\
35 & 5 & 432.0 & 1.610 & 64.00 & & & \\
\hline
\end{tabular}

standard deviations for sonic velocities of the various ages of sediments.

\section{PHYSICAL PROPERTIES, SITE 352}

No physical property data are available for this site.

\section{GEOCHEMISTRY}

\section{Inorganic Geochemistry}

Interstitial water samples were taken at both sites and analyzed. The data are presented in Table 10 . Analytical procedures and methods are discussed in Chapter 1 (this volume).

\section{Organic Geochemistry}

Neither the presence of gas nor hydrocarbons was detected at Site 336, or at Site 352 (Holes 352, 352A).

\section{BIOSTRATIGRAPHY, SITE 336}

\section{Biostratigraphic Summary}

"Glacial" sediments were recovered in Cores 1 to 13 $(0-159 \mathrm{~m})$ of Pleistocene to Pliocene age. Cores 1 to 8 contain calcareous and siliceous microfossils; below this level only siliceous fossils were found (few diatoms, silicoflagellates, radiolarians, and sponge spicules). Different amounts of pollen and dinoflagellates with reworked material are present. The nannoplankton and foraminiferal assemblages of Cores 1 to 8 are of a low diversity. Diatom and radiolarian assemblages are well preserved. Climatic changes can be recognized by: layers of nannofossil ooze intercalated in the "glacial" sediments, the different amount of ice-rafted material, which can be related to a different content of reworked Cretaceous and Tertiary nannofossils, dinoflagellates and pollen, and a different radiolarian content.

The "glacial" sequence is underlain by late to middle Oligocene sediments (Cores 14 to 19, 159-216 m), with calcareous and siliceous fossils. Nannoplankton and foraminiferal assemblages are comparable with those known from northern Europe. Late to middle Eocene sediments (Cores 20 to 37, 216-463 m) are barren of siliceous microfossils. Age determination is based on nannoplankton and benthonic foraminifera, which are rare and of low diversified assemblages. Sediments (reddish soil) overlying the basalt (Cores 38 to 40, 467.5-484.5 m) are barren of all fossil groups. The unconformity between Cores 13 and 14 includes at least the Miocene, and probably a part of the Pliocene.

\section{Foraminifera}

\section{"Glacial," Cores 1 through 13}

Cores 1 through 13 can be classified as "glacial" based on the presence in the washed residues of varying amounts of ice-rafted material, quartz and other sand grains, rock fragments, some shallow water mollusc fragments, and Cretaceous Inoceramus prisms. The microfaunal abundance of the cores varies greatly, but in general decreases downward; fossils become rare in Cores 8 and 9, are very rare in Cores 10 and 11 , and the lower half of Core 11 as well as Cores 12 and 13 are barren. The fluctuations in faunal abundance throughout this section could be explained as the result of fluctuations in ice coverage (low productivity under thick, light absorbing ice), and dilution by clastics. However, the general trend of downward decrease in faunal abundance cannot be explained in this manner because even barren samples can contain abundant ash which would not have rained in if the location were covered by ice. The decrease seems to be due to an increasing effect of carbonate dissolution, particularly since the number of corroded foraminiferal tests and test fragments increases as does the benthonic/planktonic ratio.

In most cores Neogloboquadrina pachyderma is the only planktonic foraminifera present. The percentage 


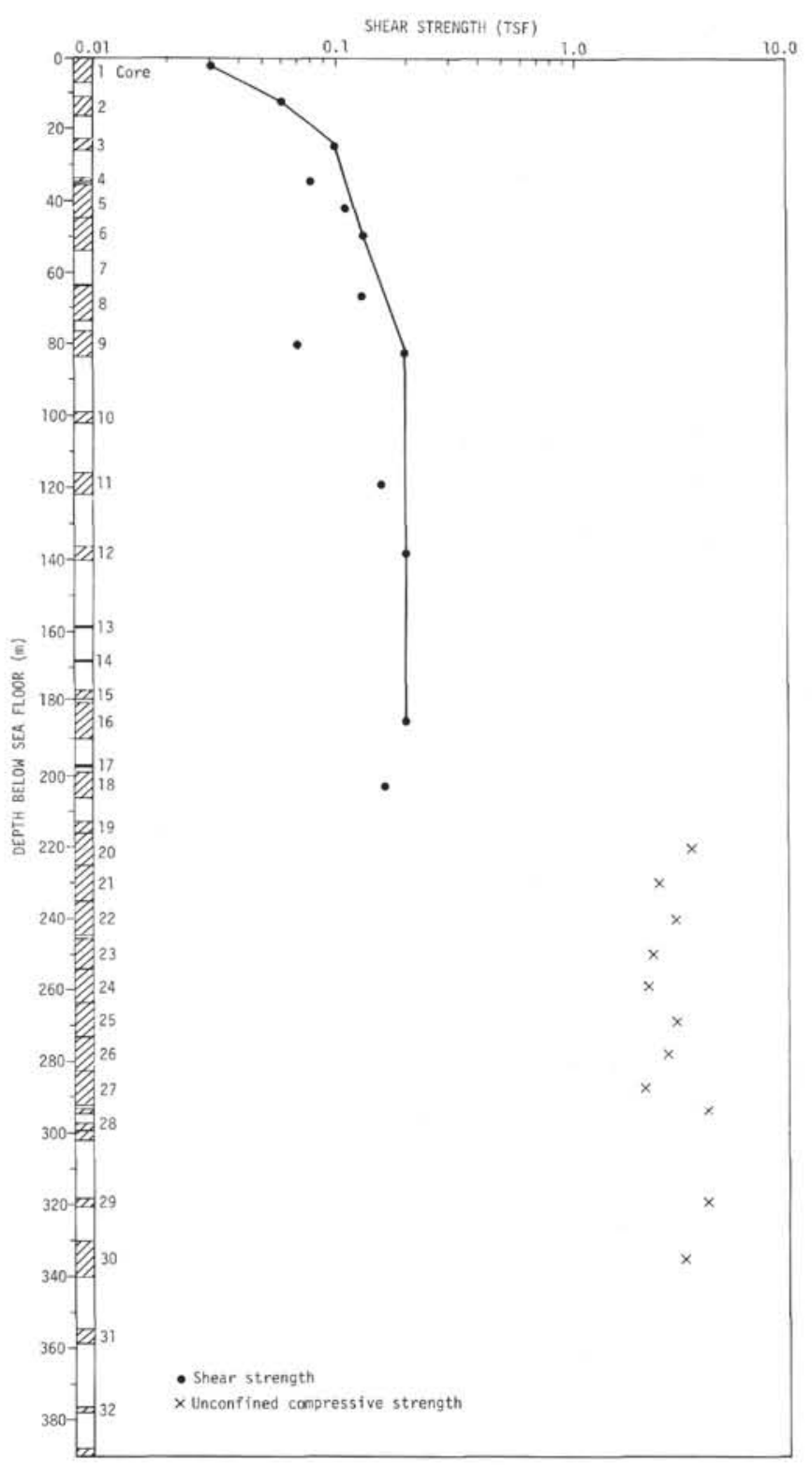

Figure 14. Shear and compressive strength profile, Site 336.

TABLE 9

Sonic Velocities of Sediments of Different Ages, Site 336

\begin{tabular}{lccr}
\hline & $x$ & $s$ & $n$ \\
\hline Plio-Pleist. (Cores 1-7) & 1.595 & 0.039 & 10 \\
Pliocene & 1.619 & 0.089 & 21 \\
Mid(?) Oligocene (Cores 16) & 1.666 & 0.034 & 5 \\
Late Eocene (Cores, 23-30) & 1.591 & 0.059 & 14 \\
Mid or late. Eocene (Cores 31-37) & 1.765 & 0.075 & 17 \\
\hline
\end{tabular}

of left-coiling specimens was determined from corecatcher samples only and was found to vary between $100 \%$ and $94 \%$. The morphology of $N$. pachyderma is widely variable between samples. They can be loosely built or compact, low spired or high spired, with or without kummerform final chamber, more or less triangular three-chambered or with a four-chambered square outline, or even with 4.5 to 5 chambers in the last whorl. No immediate stratigraphic significance of the variability could be noted. Rare specimens of Globigerina quinqueloba can sometimes be found in the finer fractions of the samples. Samples 4, CC and 8, $\mathrm{CC}$, in addition, have Globigerina bulloides, and Sample 4, CC also yielded Globigerinita glutinata and Globorotalia scitula. Although the planktonic faunal variation is minimal, its presence, as such, is most encouraging since it has climatic significance, and detailed analysis of all samples (which is in progress) will inform us on the successive advances of sea ice in this area. The benthonic foraminiferal fauna consists of a relatively low number of species (less than 20 per sample), which are all known from Recent Arctic waters.

The faunal composition, however, varies significantly between samples. Either of the following species may be dominant: Melonis zaandamae, Islandiella norcrossi, I. teretis, Elphidium incertum, or Cibicides $\mathrm{cf}$. refulgens. Other species that can be common are Bulimina marginata, Elphidium subarcticum, Buccella sp., and Astrononion gallowayi. Usually a few unilocular species are present: (Oolina, Lagena, Fissurina, Parafissurina), and from time to time Islandiella islandica, Angulogerina fluens, Virgulina concava, Nonion labradoricum, Nonionella auricula, N. turgida, Pullenia bulloides, Cassidulina sp., and Cibicides spp. are found. Milliolids and arenaceous forms are extremely rare. The relative frequencies of these species vary considerably, and a qualitative analysis may allow for paleoclimatic and paleooceanographic conclusions.

\section{Mixed Oligocene and Miocene (?), Cores 14 and 15}

Unfortunately the base of the "glacial" sequence was not recovered in the cores. Core 13 (recovered core catcher only) still is "glacial," and Core 14 contains only some glauconite sand in the core catcher. The washed residue of a small sample of Core 14 yielded one specimen of Sphaeroidina bulloides (found in the Oligocene cores below), one specimen of Elphidium incertum (that could be contamination from the PlioPleistocene above), and some (diagnostic) fragments of Martinotiella communis. The latter species ranges elsewhere through most of the Tertiary, but in the Leg 38 cores, the species was recovered consistently only from cores of Miocene age (as dated by siliceous fossils). Its presence in Core 14 strongly suggests that at least part of the glauconite section is of Miocene age. A similar mixture was found in Core 15, Samples 15-1, 17 $19 \mathrm{~cm}$ and $15-1,47-49 \mathrm{~cm}$ having the Plio-Pleistocene $N$. pachyderma, Islandiella teretis, and Melonis zaandamae, the Oligocene Angulogerina gracilis, Turrilina alsatica, Sphaeroidina bulloides, and fragments of large lenticulinids and nodosarids, and the Miocene(?) Martinotiella communis. The presence of Miocene in the glauconite section would suggest that a period of nondeposition (except for glauconite) followed the Oligocene deposition. Placing the recovery of Core 13 high in the cored interval and placing the recovery of Core 14 low would leave an 18-meter interval (150-168 $\mathrm{m}$ ) for Mio-Pliocene glauconites (ca. $0.1 \mathrm{~cm} / 1000 \mathrm{yr}$ ).

\section{Oligocene, Cores 14 through 16, Section 5}

As noted above, rare Oligocene fossils are present in Core 14 and Core 15, Section 1. Furthermore they are 
TABLE 10

Summary of Shipbaord Geochemical Data, Sites 336 and 352

\begin{tabular}{lcccccc}
\hline \multicolumn{1}{c}{ Sample } & $\begin{array}{c}\text { Subdepth } \\
(\mathrm{m})\end{array}$ & $p \mathrm{H}$ & $\begin{array}{c}\text { Alkalinity } \\
(\mathrm{meq} / \mathrm{kg})\end{array}$ & $\begin{array}{c}\text { Salinity } \\
(\% \mathrm{oo})\end{array}$ & $\begin{array}{c}\mathrm{Ca}++ \\
(\mathrm{mmoles} / 1)\end{array}$ & $\begin{array}{c}\mathrm{Mg}++ \\
(\mathrm{mmoles} / 1)\end{array}$ \\
\hline Site 336 & & & & & & \\
Surface Seawater & - & 8.32 & 2.38 & 34.9 & 10.60 & 54.01 \\
1-4, 144-150 & 6.0 & 7.96 & 3.85 & 34.4 & 10.63 & 50.61 \\
5-5, 142-150 & 43.0 & 8.25 & 4.84 & 34.1 & 11.48 & 46.08 \\
8-4, 143-150 & 70.0 & 8.09 & 5.37 & 33.8 & 13.01 & 42.81 \\
$11-4,143-150$ & 117.5 & 8.15 & 3.66 & 33.6 & 19.96 & 38.72 \\
$16-4,144-150$ & 184.0 & 8.09 & 1.97 & 35.2 & 33.12 & 33.73 \\
18-4, 153-150 & 203.0 & 7.87 & 1.74 & 35.2 & 35.61 & 32.25 \\
22-5, 140-150 & 242.5 & 8.40 & 1.00 & 34.9 & 42.71 & 28.04 \\
27-5, 141-150 & 292.0 & 8.35 & 0.80 & 36.3 & 49.66 & 26.52 \\
30-4,142-150 & 336.0 & 8.39 & 0.70 & 36.0 & 58.51 & 23.59 \\
33-5, 140-150 & 394.5 & 7.60 & 0.50 & 36.3 & 73.33 & 17.51 \\
35-3, 144-150 & 429.5 & 7.81 & 0.51 & 36.3 & 74.36 & 19.08 \\
39-3, 144-150 & 478.5 & - & 1.20 & 35.8 & 75.58 & 20.25 \\
& & & & & & \\
Hole 352 & & & & & & \\
Surface Seawater & - & 8.13 & 2.31 & 35.2 & 10.50 & 52.89 \\
2-4, 144-150 & 14.5 & 7.79 & 1.50 & 35.2 & 19.26 & 44.13 \\
Hole 352A & & & & & & \\
3-1, 144-150 & 114.5 & 7.27 & 0.45 & 35.5 & 24.33 & 39.28 \\
\hline
\end{tabular}

common in Sample 15, CC and rare in Sample 16-4, 7-9 $\mathrm{cm}$, other samples of Core 16 being barren. The fauna is largely dominated by Angulogerina gracilis tenuistriata (with rare $A$. gracilis s.s. morphotypes) of which more than 100 specimens are present in Sample 15, CC. Next in abundance is Silicosigmoilina sp. with nine specimens. All other species are very rare. The following could be determined: Melonis affinis, Turrilina alsatica, Cassidulina subglobosa, and Pullenia quinqueloba. Also present are several species of Lagena, Oolina, Fissurina, polymorphinids, and fragments of large Dentialiana, Lenticulina, and Cibicides. This fauna compares well with the northwest European Rupelian Boom Clay (Belgium, Holland), Septarienton (Germany), and Brejning Clay and Viborg Formation (Denmark).

\section{Undiagnostic Interval, Cores 17 through 21}

Below Sample $16-4,7-9 \mathrm{~cm}$, the section is practically barren of foraminifera. Most washed residues consist of sponge spicules, coproliths, some radiolarians, and a few quartz grains. Sample 20-4, 19-21 cm consists almost entirely of volcanic glass, and below this level the residues are mainly quartz grains. In this lower interval, one specimen each was found of the following non-age diagnostic arenaceous foraminifera: Silicosigmoilina sp. in 20-3, 110-112 cm, Cyclammina sp. in 20-4, 40-42 cm, Bathysiphon sp. in 21-2, 40-42 cm. On facies and comparison with other holes this interval is included in the Oligocene.

\section{Eocene, Cores 22 through 40}

From Sample 22-5, 110-112 cm down, rare calcareous forams are present. Cibicides sp. cf. $C$. tenellus is the most common form until Core 28 . Associated are specimens of: Lenticulina sp., Cassidulina sp., Alabamina sp., Bathysiphon sp., Den- talina sp., Ceratobulimina inflata, Turrilina sp., Gyroidina girardana, Spiroplectammina carinata, and Quinqueloculina carinata. Most are small and corroded specimens that do not allow for specific determination. The assemblage compares with the northwest European upper Eocene: Asse Clay (Belgium), "Bartonien" (Holland), and Barton Beds (England). The fauna of Cores 29 through 36 differs somewhat from the above and is characterized by Spiroplectammina spectabilis associated with Lenticulina cultrata, Ceratobulimina inflata, C. eximia, Cancris subconicus, Alabamina sp., Guttulina irregularis, Quinqueloculina sp., Anomalinoides anomalinoides, Cibicides sp.cf. tenellus, Cibicides sp. Lenticulina cultrata is large and dominant in Cores 32 and 33, a phenomenon sometimes used in northwest Germany as marking the upper/middle Eocene boundary. Only very few specimens were found and most are corroded. No planktonic foraminifera are present. The depositional environment must have been unfavorable for carbonate preservation.

\section{Barren Soil, Cores 37 through 40}

Wash residues of the red clay samples of Samples 37, $\mathrm{CC}$ and 38, CC have bipyramidal quartz and some white gypsum (?). The residue of Core 39 has angular quartz, feldspar, and sandstone fragments, and in Core 40 basalt fragments are also present. No fauna was recovered from these samples.

\section{Nannoplankton}

Nannoplankton are extremely rare in the "glacial" sediments recovered from Site 336. The assemblages are marked by low species diversity. The only species observed are Coccolithus pelagicus (small variety), Cyclococcolithus leptoporous, Gephyrocapsa ericsonii, and Helicosphaera carteri. The nannofossils are smaller and more fragile than in warmer water regions. The low 
amount of nannoplankton may be due to poor living conditions (low water temperatures), as well as dilution by a high amount of terrigenous material. Dissolution seems to be less important because planktonic foraminifera and nannoplankton do not show traces of dissolution. In Core 4, some nannofossil ooze layers are present consisting mainly of a very small species of the genus Gephyrocapsa. These horizons may indicate an influx of warmer water caused by climatic changes. In almost all samples, reworked species of the Cretaceous and Eocene were found. They are missing in the nannofossil ooze layers. A relationship exists between the amount of reworked species and the amount of icerafted material in the sediments.

Core 8 to Sample 14, CC (64-168.5 m) are barren of nannoplankton. In this part of the profile, only sponge spicules, few diatoms, and silicoflagellates were found.

Sample 15-1, 13-14 cm to Sample 16-5, 111-112 cm $(168.5-187.5 \mathrm{~m})$ are more or less abundant in nannofossils. They are slightly to strongly etched. The assemblages belong to the middle/upper Oligocene (NP 24/NP 25). The boundary between both zones probably lies between Sample 16-2, 11-13 cm and Sample $16-3,16-17 \mathrm{~cm}$, indicated by the occurrence of Discolithina enormis. The assemblage consists of Coccolithus pelagicus, Cyclococcolithus floridanus, Discolithina desueta, Helicosphaera euphratis, Discoaster deflandrei, Discolithina enormis, Dictyococcites dictyodus, Reticulofenestra lockeri, and only one specimen of Helicosphaera perch-nielsenasae, Zygrhablithus bijugatus, and Triquetrorhabdulus carinatus (15-1, 113-114 $\mathrm{cm})$. In some samples Reticulofenestra lockeri and/or species of the genus Discolithina are abundant.

Sample 16-6, 5-7 cm to Sample 22-5, 60-61 cm (178$243 \mathrm{~m}$ ) are barren of nannoplankton. Sample 22-6, 120 $121 \mathrm{~cm}$ to Sample 37 , CC $(243-463 \mathrm{~m})$ contain Eocene nannofossils. The sediments are very poor in nannoplankton, which are frequent only in some samples. The assemblage is of low diversity. Discoasters are missing in the Eocene indicating a cold subarctic environment. The nannoplankton assemblage from Sample 22$6,120-121 \mathrm{~cm}$ to Sample 30-2, 140-141 cm (243-333 m) consists of Isthmolithus recurvus, Reticulofenestra umbilica, Coccolithus pelagicus, Braarudosphaera bigelowi, Transversopontis obliquipons, Dictyococcites dictyodus, Chiasmolithus oamaruensis, Discolithina pulcheroides, Cribrocentrum reticulatum indicating a late Eocene age (NP 19/20). The assemblage from Sample 30-3, 110-111 $\mathrm{cm}$ to Sample 37, CC consists of Reticulofenestra umbilica, Transversopontis obliquipons, Braarudosphaera bigelowi, Discolithina pulcheroides, Coccolithus pelagicus, and a few specimens of Rhabdosphaera tenuis, Rhabdosphaera crebra, Sphenolithus radians, Zygrhablithus bijugatus, and Cyclococcolithus luminis. This assemblage indicates a middle to lower upper Eocene age. It is impossible to give a more exact age determination.

\section{Diatoms (H.-J.S.)}

Well to moderately well preserved diatom assemblages were found in Cores 1,6 , and 8 to 12 and are of Pleistocene to Pliocene age. No samples were available in Cores 13 through 15. Below, well to poorly preserved assemblages were found in Cores 16 through 19 , and no diatoms were found below Core 19 .

The occurrence of the following index species made the following biostratigraphic subdivision possible: Interval from Core 1 through Core 12-Denticula seminae, Nitzschia fossilis, Pseudoeunotia doliolus, Rhizosolenia barboi, Thalassiosira convexa, Thalassiosira nidulus, $T$. oestrupii, and $T$. usatchevii placing Sample 1-2, $89 \mathrm{~cm}$ into the Thalassiosira oestrupii Zone of 0-1.8 m.y. age; Sample 6-2, $30 \mathrm{~cm}$ into the Rhizosolenia barboi Zone of 1.8-2.5 m.y. age; and Samples $8-2,50 \mathrm{~cm}$ to $12-2,134 \mathrm{~cm}$ into the Thalassiosira kryophila Zone of 2.5-(?) m.y. age (the base was not age determined).

The interval between Core 16, Section 2 and Core 18, Section 2 contained the following age-diagnostic species: Coscinodiscus praenitidus, C. tuberculatus var. atlantica, Cymatosira spp., Hemiaulus spp., Pseudotriceratium chenevieri, Rouxia obesa, Sceptroneis spp., Triceratium schulzii, and Synedra miocenica, placing this interval into the Pseudodimerogramma filiformis Zone of upper Oligocene age. The interval between Core 18, Section 5 and Core 19, Section 2 contained only moderately to poorly preserved diatom assemblages, and only an Oligocene age could be assigned to this interval. A hiatus was found in the poorly recovered interval between Core 12, Section 2 and Core 16, Section 2, where Oligocene material underlies Pliocene material.

\section{Radiolarians}

Radiolarians and anellotubulates (manufactured "microfossils"?) were recovered from different sites. As there is a dispute in the literature on whether the anellotubulates are real of manufactured "microfossils," the sample preparation technique has been described in Bjфrklund (this volume).

Based on the occurrence of radiolarians recovered from this hole, the sediment column can be divided into three units.

Unit 1 (Cores 1 through 14) is characterized by "glacial" material, and a well-preserved modern Norwegian Sea radiolarian fauna scattered throughout. Based on piston core studies from this area, Cycladophora davisiana makes up only $2 \%-3 \%$ of the total fauna in the surface sediment, but increases to $65 \%$ and $58 \%$ in Samples 1-4, 40-42 cm and 2-1, 92-94 $\mathrm{cm}$, respectively. Radiolarians are present in the "glacial" unit in those intervals where the input of icerafted material (quartz grains) is low, corresponding to warm periods. This unit may be useful for studying late Pleistocene climatic changes as radiolarians react well to climatic changes.

Unit 2 (Samples 15, CC through 19, CC) is characterized by a relatively well preserved silica assemblage. Radiolaria, sponges, and diatoms are common in Samples 15, CC through 17, CC, while in Samples 18, CC through 19, CC, radiolarians and diatoms are rare, while sponge spicules, strongly fragmented, make up the bulk of biogenic silica. Lychnocanium bipes (one questionable specimen) was observed in Sample 16, CC. If this identification is correct, and based on the occurrence of Delicullus 
oddgurneri and Ceratocyrtis mashae, also recovered from Site 338, Sample 16, CC should be of a middle to late Oligocene age.

Unit 3 (Samples 20, CC through $40, C C$ ) is characterized by being barren of siliceous fossils in the size fraction examined.

\section{Silicoflagellates}

From Sample 8-5, 100-101 cm to Sample 12-2, 100$101 \mathrm{~cm}$, only a few specimens of Distephanus speculum are present, together with sponge spicules, and some diatoms. An age determination is not possible for this part of the profile (72-133.5 m). In Sample 15-1, 13-14 $\mathrm{cm}$ to Sample 18-3, $18-19 \mathrm{~cm}(168.5-201.5 \mathrm{~m})$ the following assemblage was found: Corbisema triacantha, Distephanus crux, Distephanus speculum, Cannopilus hemisphaericus, Naviculopsis lata, Naviculopsis ponticula, and Mesocena apiculata. This assemblage belongs to the Naviculopsis lata Zone which includes the stratigraphic interval of the upper Oligocene and the lowermost Miocene.

Samples $18-4,5-6 \mathrm{~cm}$ to $20-3,50-51 \mathrm{~cm}(203-220.5 \mathrm{~m})$ are barren of silicoflagellates. Only sponge spicules, some diatoms, and archaeomonads were observed.

Palynology (S.B.M.)

\section{Dinocysts}

Cores 40 to 36 did not reveal cysts, Cores 35 to 30 contained a few, and from Cores 29 to 16 , workable assemblages were, in general, obtained. In association with the cysts, pollen are relatively frequent. Very few samples from Core 12 and above contained cysts, and in all cases, reworking was either definitive or suspected. All assemblages are relatively species poor, but they are sufficiently diagnostic particularly in Cores 27 to 16 to allow comparison with Site 338 cyst zones (Figure 15).

The presence in Core 16, Section 5 of Chiropteridium dispersum, Problematicum III, Hystrichokolpoma rigaudae, and Tanvosphaeridium sp. I allows comparison with Zone III. Core 16, Section 2 contained a differently composed assemblage of very few species, Pentadinium $\mathrm{cf}$. taeniagerum being the only diagnostic species, present in Zones IIa to I of Site 338.

The interval 18-2 to 20-5 may be taken to represent the transition between Zones III and IV. Deflandrea phosphoritica, Thalassiphora pelagica, and Phthanoperidinium sp. are present in association with Ciropteridium dispersum and Hystrichokolpoma rigaudae (in Site 338 the transition III/IV is weakly defined due to an interval with virtually nonproductive samples.) It is interesting to observe that like Site 338, the III/IV transition coincides with a peak in the cyst/pollen curve.

Sections 21-5 to 27-5 contain a rather monotonous Zone IV to $\mathrm{V}$ assemblage, the diagnostic species being Deflandrea phosphoritica, Thalassiphora pelagica, Gonyaulacysta $\mathrm{cf}$. giuseppei, Meiourogonyaulax sp., and Phthanoperidinium amoenum.

In samples from below Core 27, cysts are infrequently present, and assemblages become much less zone diagnostic. $G$ cf. giuseppei and Meiourogonyaulax sp.

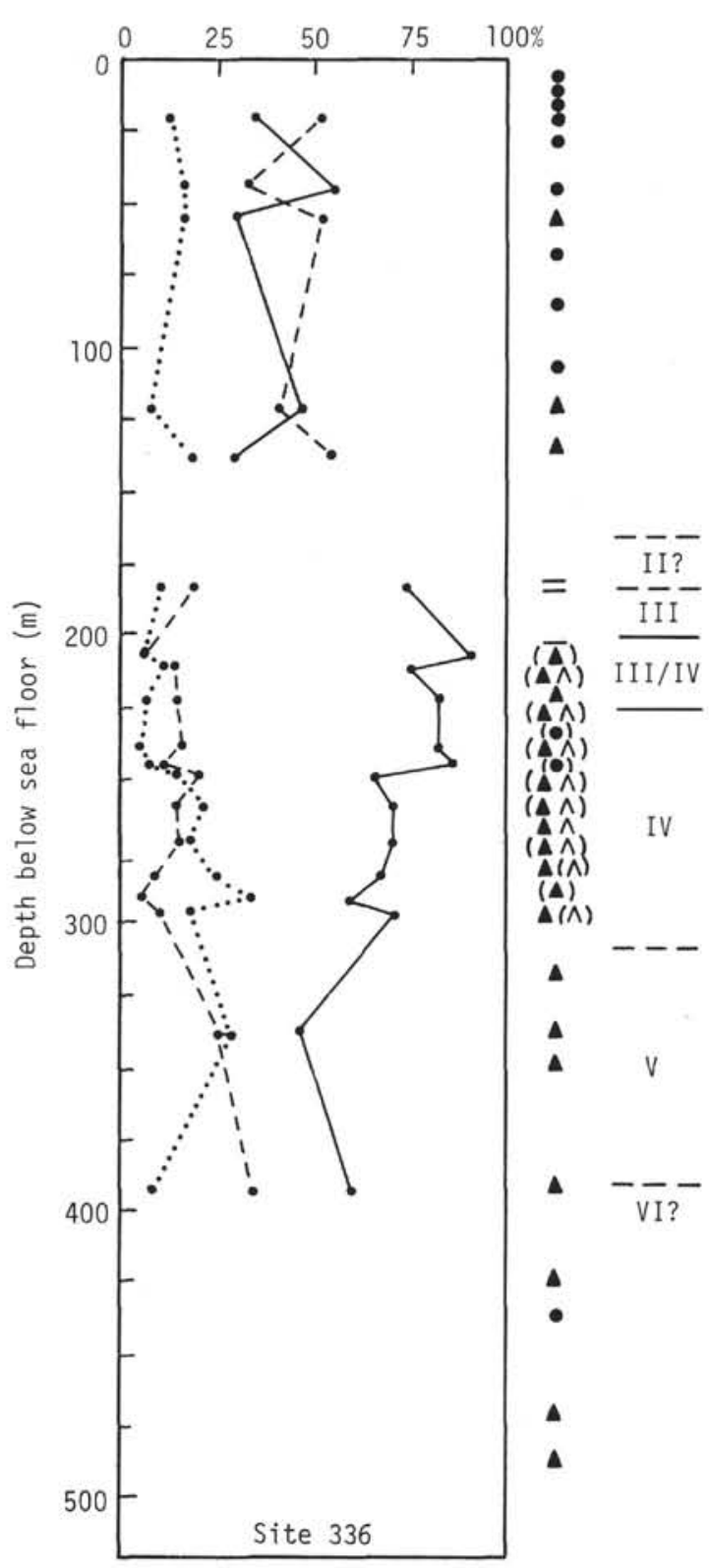

Figure 15. Relative palynomorph abundance, palynodebris composition, and dinocyst zonation (as established for 338). Legend: - dinocysts;-pollen and spores; excl. saccates $\cdots$ Saccate pollen; terrestrial plant debris: mixed cuticular and tracheidal $\Delta$ altered (dark color); $\wedge$ unaltered; sorted, tracheidal mainly $\bullet$ carbonized (opaque); o noncarbonized; - no recognizable debris; ( )debris present but not dominating in prep. residue; symbol only: debris dominating.

have not been recorded, while $D$. phosphoritica and $P$. amoenum are still present down to Core 33, Section 2, indicating Zones IV to $\mathrm{V}$ also for this part. It is suggested that the changes observed between Cores 29 and 27 may mark the Zone IV-V transition, however, it should also be observed that, at this point, local environmental changes are indicated by changes in debris composition. This may be the factor controlling the composition of cyst assemblages. 
In Core 33, Section 5, P. amoenum is not found, while Wetzeliella articulata is present suggesting that Zone VI is probably reached at that point.

\section{Debris, Reworked Material}

Prominent or dominating quantities of terrestrial plant debris are present in all preparations except for Sections 18-2 to 16-2. The dilution effect on cysts is absolute in Cores 40 to 36, severe in Cores 35 to 30, and varying in prominence from Cores 29 to 18 , Section 5. From Core 10 upwards, the debris is very monotonous, consisting of carbonized tracheidal matter, except in Sections 6-2 and 6-5 where cuticular matter is also present.

Fossils, useful as indicators of debris sources, have not been recorded below Core 12. From Cores 12 and above, scattered cysts and pollen have been recorded, for the major part apparently reworked from postCretaceous sources, but a few Cretaceous fossils have also been observed (such as Odontochitina).

\section{Sedimentation Rates}

As apparent from the paleontology report, correlations with a standard time scale are only rough estimates. The following estimates and assumptions were made: the date for initiation of strong glacial influence (ice-rafted material $0-159 \mathrm{~m}$ ) is assumed at $2.8 \mathrm{~m} . \mathrm{y}$. Consequently, the average sedimentation rate during this period is $5.6 \mathrm{~cm} / 1000 \mathrm{yr}$. A hiatus exists between the Pliocene and the underlying upper Oligocene, which includes probably the lower part of the Pliocene, and the Miocene (19.5 m.y.). The Oligocene/Eocene boundary (37.5 m.y.) at Site 336 is drawn at 254 meters, thus giving a sedimentation rate of $0.63 \mathrm{~cm} / 1000 \mathrm{yr}$., assuming a complete Oligocene section. The base of the fossiliferous sediments $(463 \mathrm{~m})$ at Site 336 is of middle Eocene (or late?) age (approximately 46 m.y.), giving an average rate of sediment accumulation of $2.5 \mathrm{~cm} / 1000$ yr.

\section{BIOSTRATIGRAPHY, SITE 352}

\section{Biostratigraphic Summary}

"Glacial" sediments (Pliocene to Pleistocene) of Cores 1 to $6(0-46 \mathrm{~m})$ are poor in nannofossils, while they are relatively rich in planktonic and benthonic foraminifera. Few radiolarians were observed; however, reworked Cretaceous and Paleogene species are abundant.

In Sample 6, CC from Hole 352, and in Cores 1 to 6 $(94-113 \mathrm{~m})$ from Hole $352 \mathrm{~A}$, rich diversified nannoplankton and foraminiferal assemblages of middle Oligocene age are present, comparable with those described from the North Atlantic (Leg 12, Rockall Bank). Nannoplankton and foraminiferal assemblages indicate shallow water. Sponge spicules are frequent in the nannoplankton ooze, while other siliceous microfossils are missing.

\section{Foraminifera}

\section{“Glacial" Pleistocene, Hole 352, Cores 1 through 5}

At this site, south of the Iceland-Faeroe Ridge, as well as at Site $\mathbf{3 3 6}$ the planktonic foraminiferal fauna is dominated by sinistrally coiling Neogloboquadrina pachyderma. However, some additional species (Globigerina quinqueloba, G. bulloides, and Globorotalia inflata) are quite common in the upper two cores. They become very rare in Cores 4 and 5 which practically have only compact $N$. pachyderma except, oddly enough, some specimens of Globorotalia truncatulinoides in Sample 5-3, 51-53 cm and G. crassaformis in 5, CC. The presence of G. truncatulinoides confirms the Pleistocene (by all standards) age of the core.

The benthos of the two higher cores is considerably more diverse than at the site north of the ridge. Present are: Islandiella teretis, I. islandica, Cibicides refulgens, C. kullenbergi, Rupertia stabilis, Paranomalina coronata, Pullenia bulloides, $P$, quinqueloba, Melonis zaandamae, Elphidium incertum, Bulimina aculeata, B. marginata, B. costata, Hoeglundina elegans, Eggerella bradyi, Elphidium spp., Lagena spp., Oolina spp., Fissurina spp., miliolids, lenticulinids, nodosarids, and others. The fauna of Cores 4 and 5 is less diverse with Cibicides refulgens, Islandiella teretis, Bulimina aculeata, or Hoeglundina elegans as the dominant species.

In the upper part of Core 1 (seven samples, down to $1-5,30-32 \mathrm{~cm}$ ) the benthos is less than $5 \%$ of the total foraminiferal fauna. Lower, however, the benthonic percent is generally higher. This reduction in plankton does not seem to be due to carbonate dissolution but rather is due to mixing with displaced shallow water fauna and possibly low planktonic production. Fragments of thick-walled pelecypods, gastropods, echinoderms, and bryozoans are common and further indicate the presence of a displaced shallow water fauna.

The bulk of the washed residues (mostly over 80\%) does not consist of foraminifera but ice-rafted clastics. Although the amount of basalt fragments is generally higher than at Site 336, quartz, fragments of sedimentary and metamorphic rock, and Cretaceous Inoceramus prisms are also present. This indicates that the material did not originate exclusively from Iceland. None of the samples is barren. Ash is a common constituent of most residues.

The base of the "glacial" section is not defined in the cores. Core 5 is highly distorted and probably is a mixture of uphole material. The washed residues are very coarse. Core 6 yielded only a few large basalt pebbles and some small siliceous chalk pebbles (Oligocene, nannos). No trace of Miocene or Pliocene deposits has been found.

\section{Oligocene, Hole 352A, Cores 1 through 3}

Recovery of the three cores of the second hole was poor. The washed residues consist of more than 50\% sponge spicules, but the rest of the oozes constitutes a quite rich, Atlantic, late to late middle Oligocene foraminiferal fauna. Planktonic species are: Globigerina gortanii, $G$. venezuelana, $G$. officinalis, G. ampliapertura, Cassigerinella chipolensis, Catapsydrax unicava, and Globorotalia opinma nana. Some of the benthonics are: Karreriella subcylindrica, Vulvulina jarvisi, Textularia spp., Tolypammina sp., Ammodiscus sp., Lagena spp., Oolina spp., Pseudonodosaria sp., Nodosaria sp., Stilostomella gracilliosa, S. verneuili, Lenticulina spp., 
polymorphinids, Pullenia bulloides, P. quinqueloba, Siphonina advena, Angulogerina gracilis, Bolivina fastigia, Uvigerina sp., Cassidulina subglobosa, Alabamina tangentialis, Melonis affine, Heterolepa mexicana, Anomalinoides sp., Planulina sp., Gyroidina girardana, Eponides umbonatus, and others. These planktonic and benthonic faunas and facies compare with the Oligocene of Rockall Bank (DSDP Sites 116, $117)$ and are strikingly different than the Oligocene of Site 336 demonstrating that (at least during the Oligocene) the Iceland-Faeroe Ridge formed an effective barrier between the Atlantic and the NorwegianGreenland Sea.

\section{Nannoplankton}

The "glacial" sequence recovered at Hole 352 (Cores 1 through $6,0-54.5 \mathrm{~m}$ ) is poor in nannoplankton. The species diversity is low, and the amount of nannofossils is small. Coccolithus pelagicus and Gephyrocapsa ericsonii are the only species which are frequent. Cyclococcolithus leptoporous and Helicosphaera carteri are very rare. Most of the samples contain only reworked Cretaceous and Eocene species. Cores 4 and 5 (27.5-38 m) are barren of nannoplankton.

In Sample 6, CC, some white fragments were found containing a very rich nannoplankton assemblage of middle or late Oligocene age (Sphenolithus distentus/Sphenolithus ciperoensis Zone, NP 24/NP 25) with: Dictyococcites dictyodus, Zygrhablithus bijugatus, Coccolithus abisectus, Cyclococcolithus floridanus, Coccolithus pelagicus, Chiasmolithus altus, Sphenolithus moriformis, Helicosphaera euphratis, and Reticulofenestra clatrata. It is presumed that in Sample 6, CC, the Oligocene was just touched which is overlain by the "glacial" sequence. At least parts of the Pliocene and Miocene are missing.

The middle or upper Oligocene (NP 24) was encountered at Hole 352A at 94 meters. The sediments consist of a white nannofossil ooze rich in foraminifera and sponge spicules, while diatoms, radiolarians, and silicoflagellates are probably dissolved. The nannoplankton assemblage is of a high diversity consisting of: Dictyococcites dictyodus, Cyclococcolithus floridanus, Coccolithus abisectus, Sphenolithus moriformis, Coccolithus pelagicus, Zygrhablithus bijugatus, Chiasmolithus altus, Helicosphaera recta, Discoaster deflandrei, Discolithina desueta, Helicosphaera euphratis, Braarudosphaera bigelowi, and Reticulofenestra clatrata. The preservation is good in Core 1 , but nannofossils are overgrown in Cores 2 and 3. Zygrhablithus bijugatus becomes very frequent in the Oligocene indicating a shallow water environment.

The assemblage is comparable with that observed at Site 336 (north of Iceland-Faeroe Ridge); however, Zygrhablithus bijugatus is nearly absent at Site 336 . The unconformity encountered at Holes 352 and 352A ("glacial"--middle Oligocene) is also present at Site 336.

\section{Diatoms (H.-J.S.)}

No samples were studied from Site 352.

\section{Radiolarians}

This hole was regarded as very important in trying to link together the North Atlantic and Norwegian Sea radiolarian assemblages. Unfortunately, Miocene sediments were not recovered from Holes 352 and $352 \mathrm{~A}$; however, glacial marine sediments poor in radiolarians were recovered, directly overlying latemiddle Oligocene sediments, which were poor in radiolarians. The Oligocene radiolarians were rare, strongly fragmented, and not determinable. Consequently the radiolarian assemblages north and south of the Iceland-Faeroe Ridge could not be compared. Sponge spicules, the bulk of biogenic silica, are also strongly fragmented and corroded, which are the same conditions Benson (1972) reported for samples from the Labrador Sea.

\section{Silicoflagellates}

Only few silicoflagellates were found in Sample 352A-3-1, 65-66 cm (Oligocene), rich in volcanic glass. The assemblage consists of Dictyocha speculum and Cannopilus hemisphaericus.

\section{Sedimentation Rates}

A Plio/Pleistocene sequence of 46.5 meters was recovered from Hole 352 . Assuming 2.8 m.y. for the base of "glacial sediments," this is a sedimentation rate of $1.6 \mathrm{~cm} / 1000 \mathrm{yr}$. At 46.5 meters, the middle Oligocene was cored. This indicates a hiatus which includes the upper Oligocene, the Miocene, and probably a part of the Pliocene. This hiatus corresponds to that recovered at Site 336 on the southern flank of the Iceland-Faeroe Ridge.

\section{SUMMARY AND CONCLUSIONS-SITE 336}

\section{General}

Hole 336 was drilled to a total depth of 515 meters, the last 30.5 meters being in basalt. The material drilled is clearly divisible into four units.

The top unit extends from the sea bed down to 168.5 meters, and consists largely of clays and sands containing a large percentage of glacially derived material. The nature of its contact with the underlying unit is not known, because recovery in Core 14, which would presumably have contained this contact, was very small and yielded only a small amount of black glauconitic sand with no fossils. The age at the bottom of this unit is late Oligocene.

The second unit, generally a firm stiff mudstone extends from 168.5 meters to 463 meters ranging in age from late Oligocene to middle or late Eocene. This unit is more lithified than the first unit, and the lithification noticeably increases towards the base. It also contains a number of well-defined ash layers.

The third unit extends from 463.0 meters to 484 meters, and appears to be derived almost entirely from the underlying basalt. It grades from an uppermost reddish clay, through a multicolored claystone which shows signs of mineralization, to a rubble containing clasts of volcanic rock in a more altered matrix. This rubble grades into the basalt layer itself. The lower part of this unit seems to have been formed by in situ weathering of basalt, although the upper part represented in the reddish clay may have undergone erosion and redeposition. 
The fourth unit in which the hole bottomed is basaltic basement. A radiometric age determination yields 41-43 m.y. (late Eocene).

\section{Comparison with Seismic Reflection Record}

The seismic reflection record shows two prominent subbottom reflections. The upper has a subbottom double travel time of 0.2 seconds. It can be identified with the unconformity at the top of the upper Oligocene. The 168.5 meters of overlying section then yields a seismic velocity of $1.69 \mathrm{~km} / \mathrm{sec}$, which is slightly higher than the mean velocity of $1.62 \mathrm{~km} / \mathrm{sec}$ determined for Core 1-10 (see section on Physical Properties), but this, and other similar differences, can probably be attributed to the problems in determining velocity in sediment that has been disturbed.

The second subbottom reflector has a total subbottom double travel time of 0.58 seconds, and is identified with the top of the basement. The 316 meters of overlying section yields a seismic velocity of $1.66 \mathrm{~km} / \mathrm{sec}$, which is again slightly higher than the mean velocity of $1.60 \mathrm{~km} / \mathrm{sec}$ determined for Cores 21 through 30 . It is curious that in spite of the obvious results of compaction, the velocity of the Tertiary sediments is no higher than the velocity of the Pleistocene sediments. The simplest way to explain this is by assuming that the rocks from which the Tertiary sediments are derived have distinctly lower densities, than the rocks from which the later sediments were derived.

\section{Age of Basement}

The oldest sediments overlying basement are at least as old as late Eocene. Probably the age from data on foraminifera extends to middle Eocene. Radiometrically determined ages of $40.4 \pm 3.2 \mathrm{~m} . \mathrm{y}$. by the Russian group and $43.4 \pm 3.3$ m.y. by the German group are only slightly younger and confirm the late/middle Eocene age for basement.

\section{Sedimentation Rates}

The sedimentation rates in the top most unit ( $159 \mathrm{~m})$ are the highest. The exact age of the bottom of this unit is not known, but assuming that it is $2.8 \mathrm{~m} . \mathrm{y}$. the minimum rate of sedimentation is $5.6 \mathrm{~cm} / 1000 \mathrm{yr}$. The calculated rates for the Oligocene and the Eocene (?) are, respectively, $0.63 \mathrm{~cm} / 1000 \mathrm{yr}$., and $2.5 \mathrm{~cm} / 1000 \mathrm{yr}$.

But perhaps the most striking thing about the sedimentary history at this site is the absence of any sediments from the upper Oligocene to the Pliocene. This interval of more than 19.5 m.y. represents the major part of the time interval at this site during which sedimentation could have taken place. As always in such situations the question arises how much of the gap in the sedimentary column is due to nondeposition, and how much is due to erosion.

\section{Subsidence}

The nature of the "rubble" immediately above the basalt suggests subaerial weathering. The lack of any evidence of rigorous reworking in shallow water, together with the presence of finer clay at the top of the lithologic Unit 3 which can be attributed to redeposition, suggest rapid submergence of the basalt and the overlying weathered layer. (However, it is possible that wave action was so gentle that it is not necessary to invoke very rapid submergence).

Continued submergence to the Oligocene is suggested by decrease of grain size in the sediments pointing towards deposition in deeper waters, and by the ratio of planktonic/benthonic foraminifera. The latter indicated inner-middle neritic environment at $45 \mathrm{~m} . \mathrm{y}$., neritic at 37 m.y., and outer neritic to upper bathyal at 30 m.y. Three alternative possibilities are suggested for the upper Oligocene-Pliocene hiatus: (1) sediment deposition stopped at the upper Oligocene and did not resume until the glaciation; (2) sediment accumulates until the advent of glaciation, then eroded to the top of the late Oligocene, and then "glacial" sediments were deposited; (3) non deposition and erosion are allowed to start during the Miocene. All of the alternatives imply that no deposition was going on at a depth of 1000 meters at the end of the Tertiary. Finally the extreme case can be mentioned where sediments are eroded by assuming an emergence during the Tertiary or Quaternary.

\section{Climate Changes During the Quaternary}

Further study of the cores is essential to indicate the climatic changes during the Quaternary. Very preliminary study from core catcher samples shows (see report on Radiolaria and History of Ice Rafting) that Cores $4,5,8,10$, and 11 may represent warm periods, while Cores 1 through $3,6,7,9,12$, and 13 may indicate cold periods. Because of the large sampling interval no precise inferences concerning the number of climatic oscillations can be made.

\section{Paleogeography and Evolution of Iceland-Faeroe Ridge}

We will attempt to interpret the information obtained from cores at Site 336 in terms of a model for the evolution of the Norwegian Sea in terms of sea-floor spreading. In this model, the unusual elevation of the Iceland-Faeroe Ridge is interpreted as the trail of a "hot spot" in the mantle.

There is controversy about whether the Faeroes lie on continental crust, or whether they belong genetically to the oceanic Iceland-Faeroe Ridge. Site 336 lies far enough away from the Faeroes, so that regardless of the controversy about the Faeroes, this site can be safely assumed to be a normal part of the Iceland-Faeroe Ridge.

Shore based analysis suggests that the basalt at this site may not be typical of the tholeiitic basalts formed typically in mid-ocean rifts. However the range of basalts, in Iceland for example, which also has an origin by sea floor spreading in association with an underlying hot spot, is so large that it is not possible to rule out the formation of basalt at Site 336 through extrusion involved in sea floor spreading. This argument is, of course, invalid if Iceland was not created by sea floor spreading.

The overlying rubble and sediments have been derived from the basalt, and the contact of these beds with the middle or late Eocene claystones was not observed. However, if we accept the subsidence history of this site which was discussed earlier, it suggests strongly, though 
it does not prove, that there is no major gap in time between the claystones, which were deposited in shallow waters, and the basalt. If this is accepted, the age of the basalt is also middle or late Eocene. This age does not conflict with that predicted under the sea floor spreading model, since the Iceland-Faeroe Ridge was created during the time between the initiation of sea floor spreading in the Norwegian Sea in the Paleocene (about 60 m.y. ago), and the birth of Iceland in the late Oligocene.

If at the time of its formation, Site 336 was at or near sea level, the highest point along the active axis of the Iceland-Faeroe Ridge (the spreading axis was presumably transverse to the strike of the ridge) was much higher. At the present time, the difference between basement elevation at Site 336 and at the top of the Iceland-Faeroe Ridge is about 950 meters. Ignoring erosion and subsidence due to loading, we can roughly postulate that this difference in the two elevations has been maintained. Thus the initial elevation of the crest of the ridge at the spreading axis was about 950 meters, and it would take roughly 30 m.y. for the crest of the ridge to subside below sea level as it moved away from the spreading axis.

These calculations use very gross approximations and assumptions, and could therefore be grossly in error. However they do supply the picture of a spreading ridge over a hot spot, where the highest elevation along the spreading axis is several hundred meters above sea level, and it takes tens of millions of years for the highest point to subside below sea level.

An important shift in the spreading axis occurred about 30 m.y. from the Norway Basin to the IcelandJan Mayen Ridge. It is quite possible that a similar shift also occurred from the Iceland-Faeroe Ridge to Iceland at the same time. If this is so, we can think of the Iceland-Faeroe Ridge being formed in the interval 60 m.y. to 30 m.y. By the arguments suggested earlier, this ridge was emergent during this entire period, and only after the shift of the ridge axis did it begin to be submerged below sea level.

During this time Norway Basin was closed off on three sides by the Jan Mayen Ridge (then attached to Greenland), Iceland-Faeroe Ridge, and continental margin of Norway. Therefore the northern flank of the Iceland-Faeroe Ridge had no connection with the North Atlantic. The disparity of the Oligocene fauna at Site 336 with typical North Atlantic fauna bears this out.

As the Iceland-Faeroe Ridge began to submerge the flow of water in the shallow straits would have been increasingly responsible for non deposition and erosion. We are not sure how much sediment was deposited in Miocene and Pliocene times at Site 336, but certainly current activity must have played an important role in preventing sediment to be deposited, and in possibly eroding older sediments.

\section{SUMMARY AND CONCLUSIONS-SITE 352}

Operational problems severely restricted the amount of material recovered from two holes at Site 352 . The holes had to be abandoned at 103.5 and 122.5 meters, respectively, well above basement. Although the intention was to core continuously, the presence of sand and gravel beds in the "glacial" prevented us from doing so. In particular, we are now not quite certain about the depth location for base of the "glacial."

The presence of a chalk pebble from Hole 352 in Core 6, CC at 54.5 meters in which middle Oligocene nannofossils were obtained, suggests that "glacial" directly overlies the middle Oligocene. Middle Oligocene fauna was found in the first core taken at 94 meters in Hole $352 \mathrm{~A}$. Hole $352 \mathrm{~A}$ was washed through to 94 meters, and drilling records from Hole 352A suggest penetration to softer sediments at 54 meters, and harder sediments again at 90 meters. If the chalk pebble at 54.5 meters from Hole 352 is in place and has not been derived together with basaltic pebbles as rubble later on, the possibility exists that the middle Oligocene does extend up to 54 meters. Thus while we suspect the Pliocene and Miocene sediments are missing here, we cannot be absolutely sure since we are not absolutely sure that the chalk pebble was deposited in place.

Lithologically, the "glacial" sediments consist of muds, sandy muds and pebbles. The "glacial" sediments were rich in planktonic foraminifera, as well as benthonic forms. The sediments were poor in nannoplankton and radiolarians.

The Oligocene sediments consist of a calcareous nannofossil ooze with localized chalk and chert zones. A rich middle Oligocene foraminiferal, as well as nannoplankton fauna exists. Radiolarians are poor and sponge spicules are present, but strongly fragmented and corroded. The presence of opaque masses of amorphous silica, and evidence of silicification points to the dissolution of siliceous fossils and redeposition of silica.

It is interesting to contrast the results obtained at Holes 352 and $352 \mathrm{~A}$ with those obtained at Site 336 on the northern flank of the Iceland-Faeroe Ridge. The "glacial" sediments are thinner at Site 352; however, the reflection profiler records show evidence of local variations in thickness of a top layer within the sediments. It is possible that the difference in thickness of "glacial" sediments may not be significant. The absence of Miocene sediments at Site 352 (subject to the reservations noted above) is strikingly similar to their absence at Site 336. As noted in discussion of the results from Site 336, we are not sure why these sediments are absent. The close proximity of the two sites would suggest that whatever the reasons are, they are similar at both sites.

The difference in the middle Oligocene fauna at the two sites suggests the presence of an emerged IcelandFaeroe Ridge, which at that time blocked the connection between the North Atlantic and the Norwegian Sea at least until the middle Oligocene.

\section{REFERENCES}

Benson, R.N., 1972. Radiolaria, Leg 12, Deep Sea Drilling Project. In Laughton, A.S., Berggren, W.A., et al., Initial Reports of the Deep Sea Drilling Project, Volume 12: Washington (U.S. Government Printing Office), p. 10851113.

Cann, J.R., 1971. Major element variation in ocean floor basalts: Phil. Trans. Roy. Soc. London, v. A268, p. 495506. 
Collinson, D.W., 1968. An estimate of the hematite content of sediments by magnetic analysis: Earth Planet. Sci. Lett., v. 4 , p. $417-421$.

Creer, K.M., 1961. Superparamagnetism in red sandstones: Geophys. J. Roy. Astron. Soc., v. 5, p. 16-28.

Dunlop, D.J., 1972. Magnetic mineralogy of unheated and heated red sediments by coercivity spectrum analysis: Geophys. J. Roy. Astron. Soc., v. 27, p. 37-55.

Eldholm, O. and Windisch, C.C., 1974. Sediment distribution in the Norwegian-Greenland Sea: Geol. Soc. Am., v. 85, p. 1661-1676.

Irvine, T.N. and Baragar, W.R.A., 1971. A guide to the chemical classification of the common volcanic rocks: Canadian J. Earth Sci., v. 8, p. 523-548.

Johnson, H.P. and Merrill, R.T., 1973. Low-temperature oxidation of a titanomagnetite and the implications for paleomagnetism: J. Geophys. Res., v. 78, p. 4938-4949.

Johnson, H.P., Lowrie, W., and Kent, D.V., 1975. Stability of anhysteretic remanent magnetization in fine and coarse magnetite and maghemite particles: Geophys. J. Roy. Astron. Soc., v. 41, p. 1-10.

Johnson, G.L. and Tanner, B., 1973. Geophysical observations on the Iceland-Faeroe Ridge. Jökull, v. 21, AR, p. $45-52$.
Jones, E.J.W., Ewing, M., Ewing, J.I., and Eittreim, S.L., 1970. Influences of Norwegian Sea overflow water on sedimentation in the northern North Atlantic and Labrador Sea: J. Geophys. Res., v. 75, p. 1655-1680.

Lowrie, W. and Fuller, M., 1971. On the alternating field demagnetization characteristics of multidomain thermoremanent magnetization in magnetite: J. Geophys. Res., v. 76, p. $6339-6349$.

L $\phi$ vlie, R., 1975. The oxidation state of some Tertiary rocks from the Faeroe Islands and its implications for palaeomagnetism: Geophys. J. Roy. Astron. Soc., v. 40, p. 5565.

L $\phi v$ lie, R. and Kvingedal, M., 1975. A paleomagnetic discordance between a lava sequence and an associated interbasaltic horizon from the Faeroe Islands: Geophys. J. Roy. Astron. Soc., v. 40, p. 45-54.

Richards, A.F., 1962. Investigation of deep sea sediment cores. II. Mass physical properties: U.S. Navy Hydrographic Office, Publication TR-106, $146 \mathrm{p}$.

Storetvedt, K.M., 1972. The rotation of Iberia; Caenozoic palaeomagnetism from Potrutal: Tectonophysics, v. 17, p. 23-39.

Watkins, N.D., Keany, J., Ledbetter, N.T. and Huang, T.C., 1974. Antarctic glacial history from analyses of ice-rafted deposits in marine sediments: new model and initial tests: Science, v. 186, p. 533-536. 


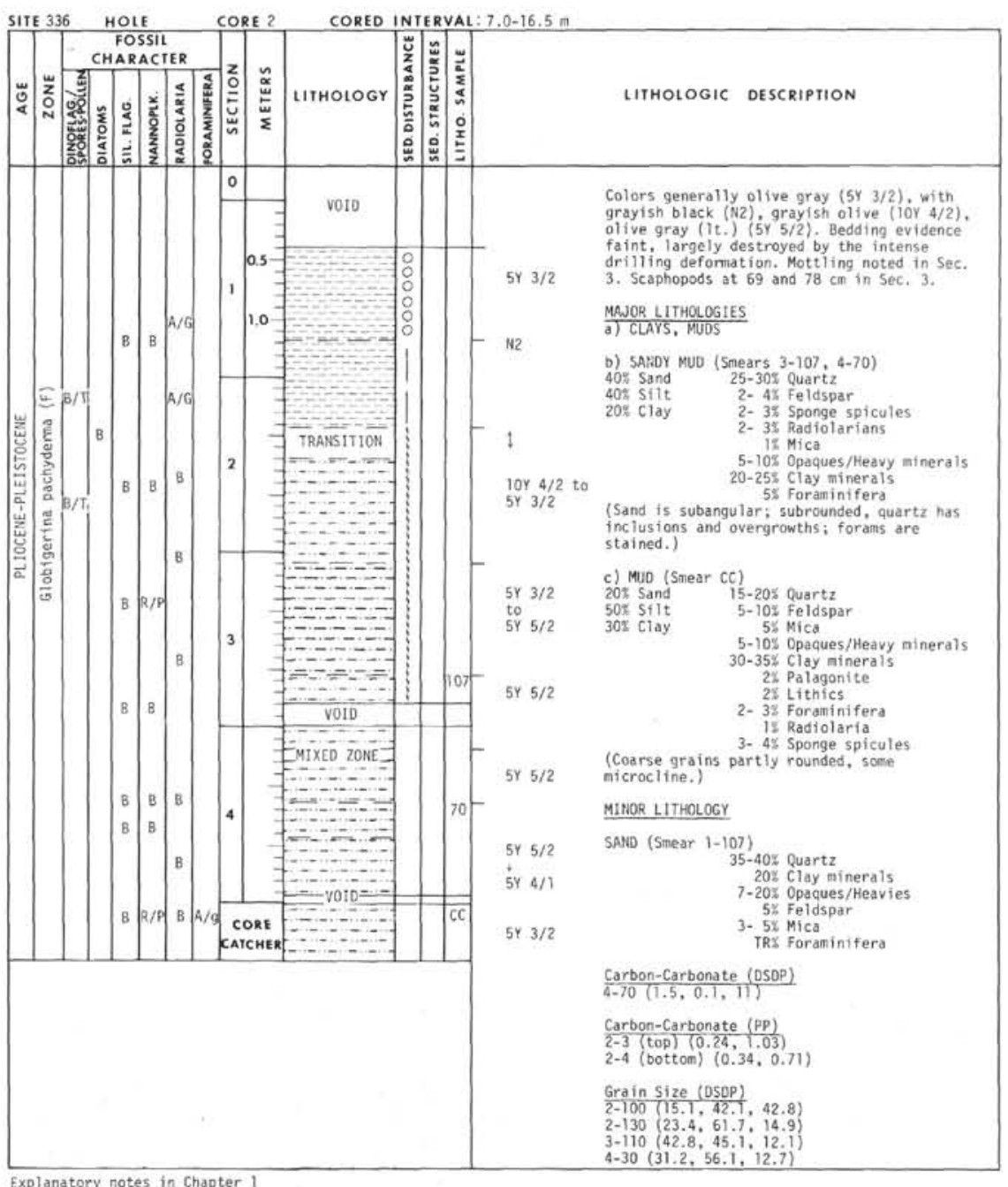




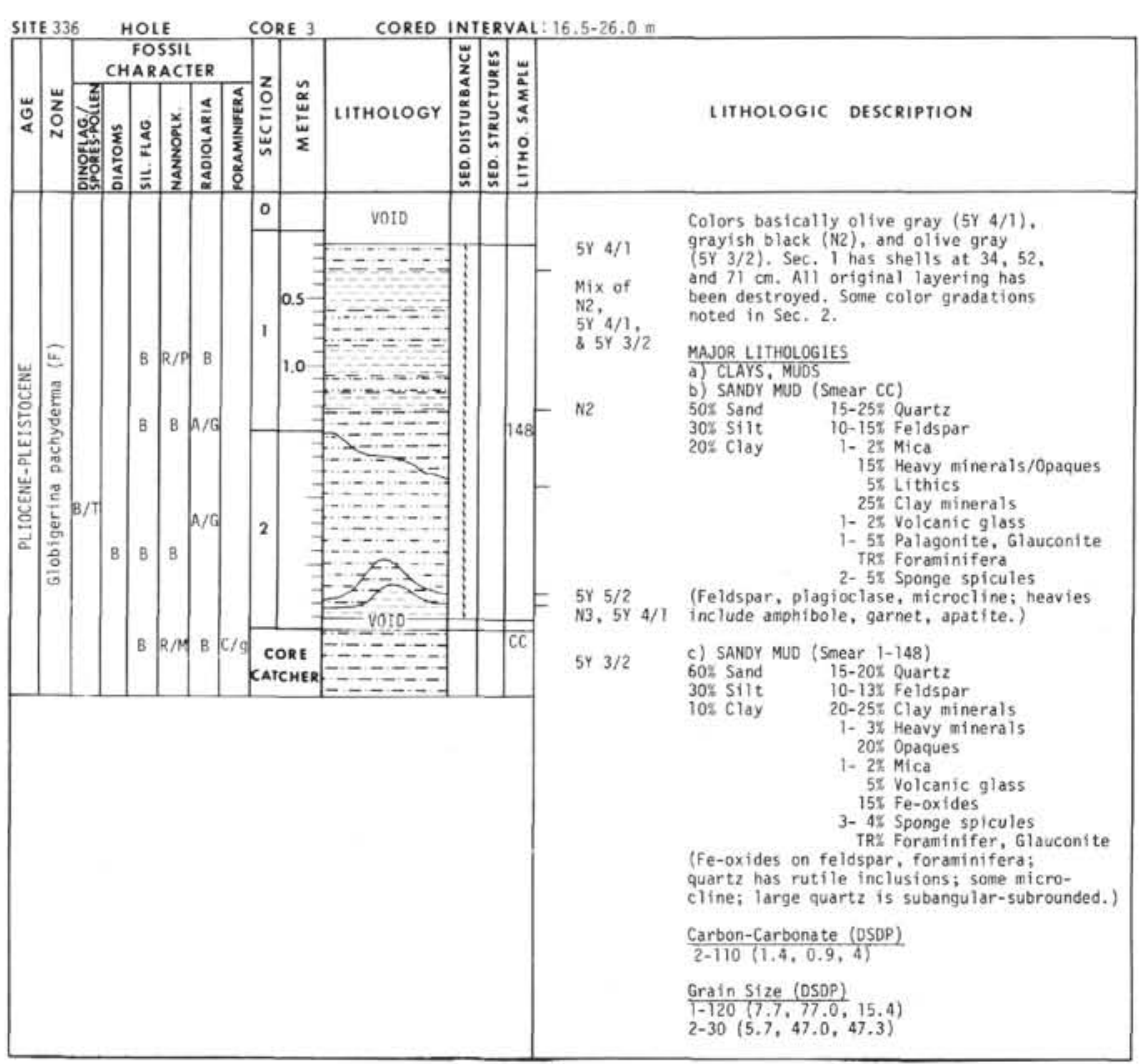

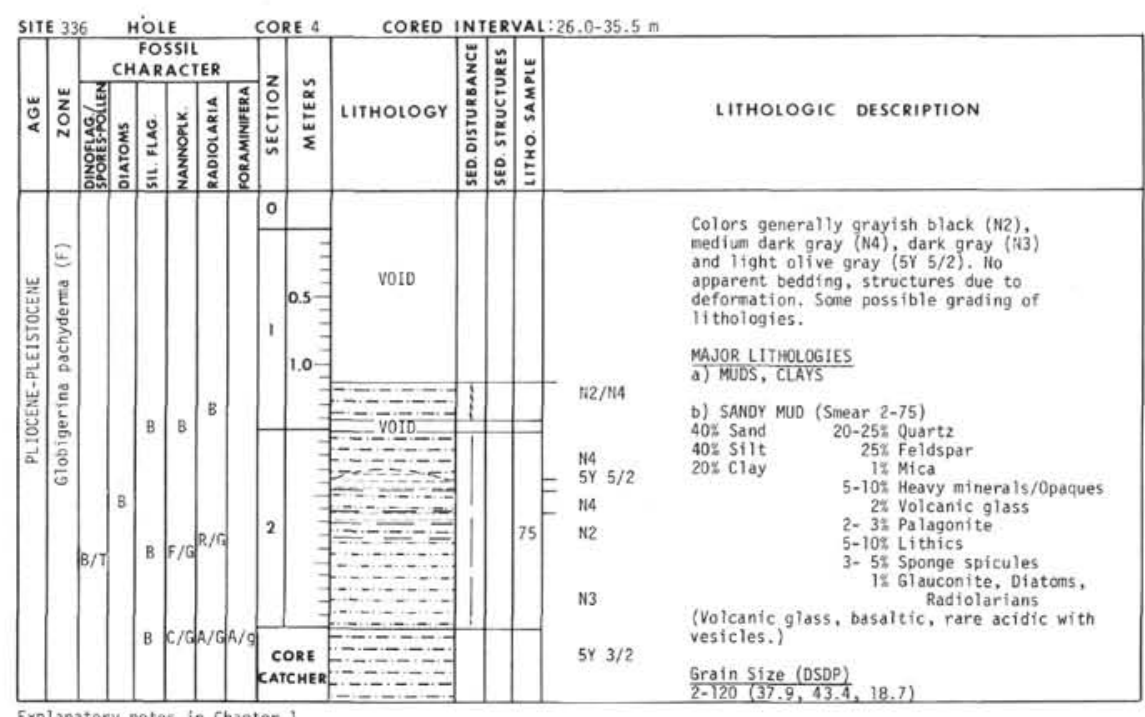



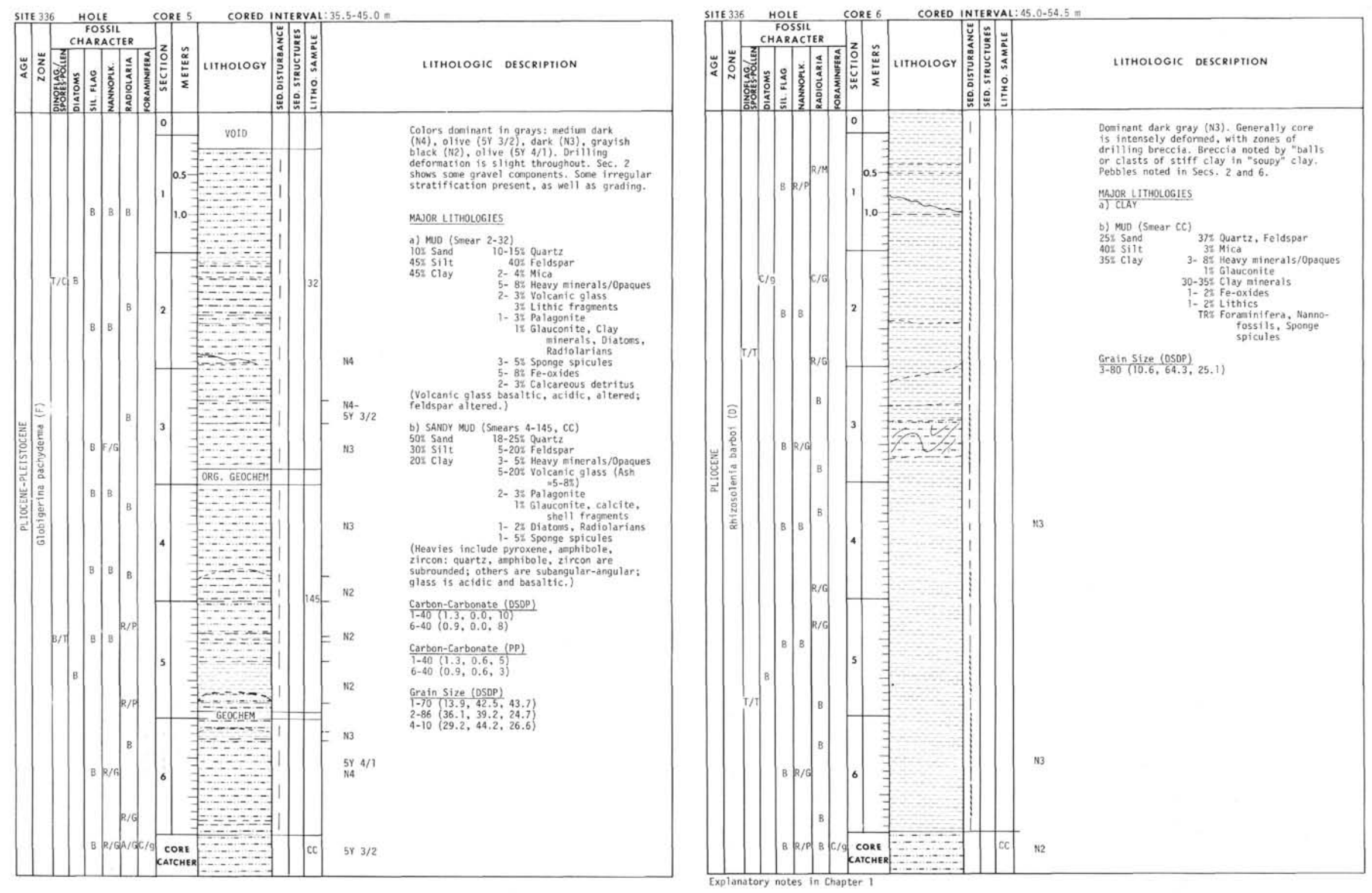


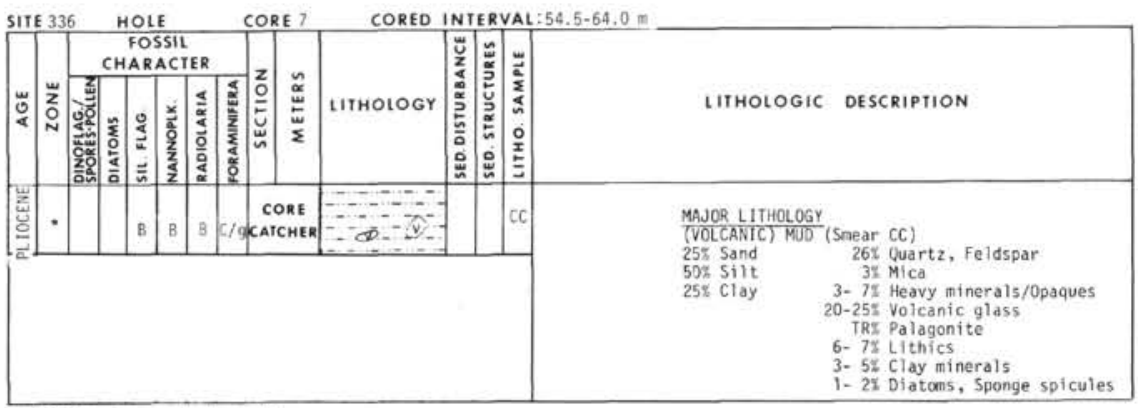

- Globigerina pachyderna (F)

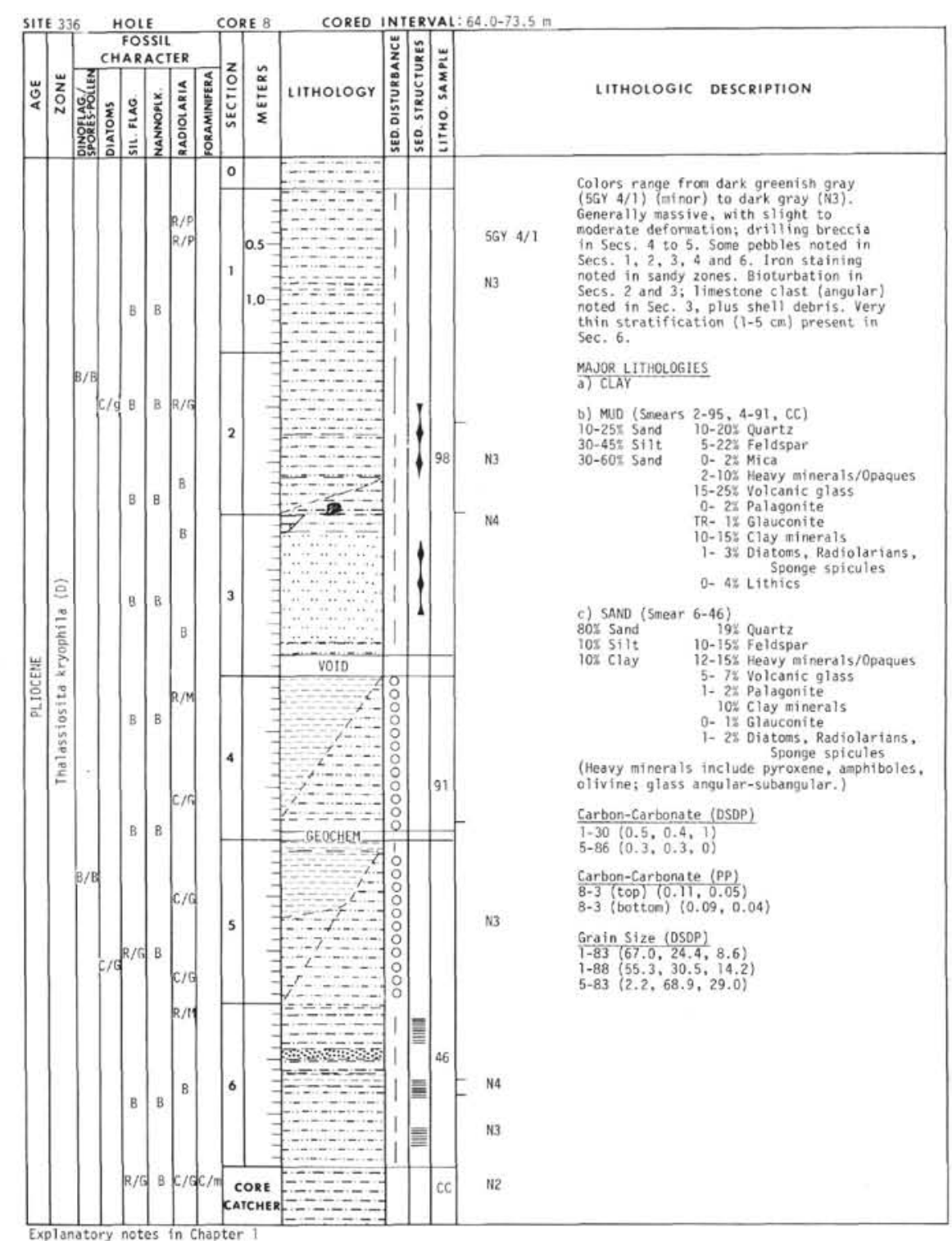

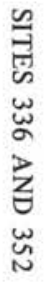



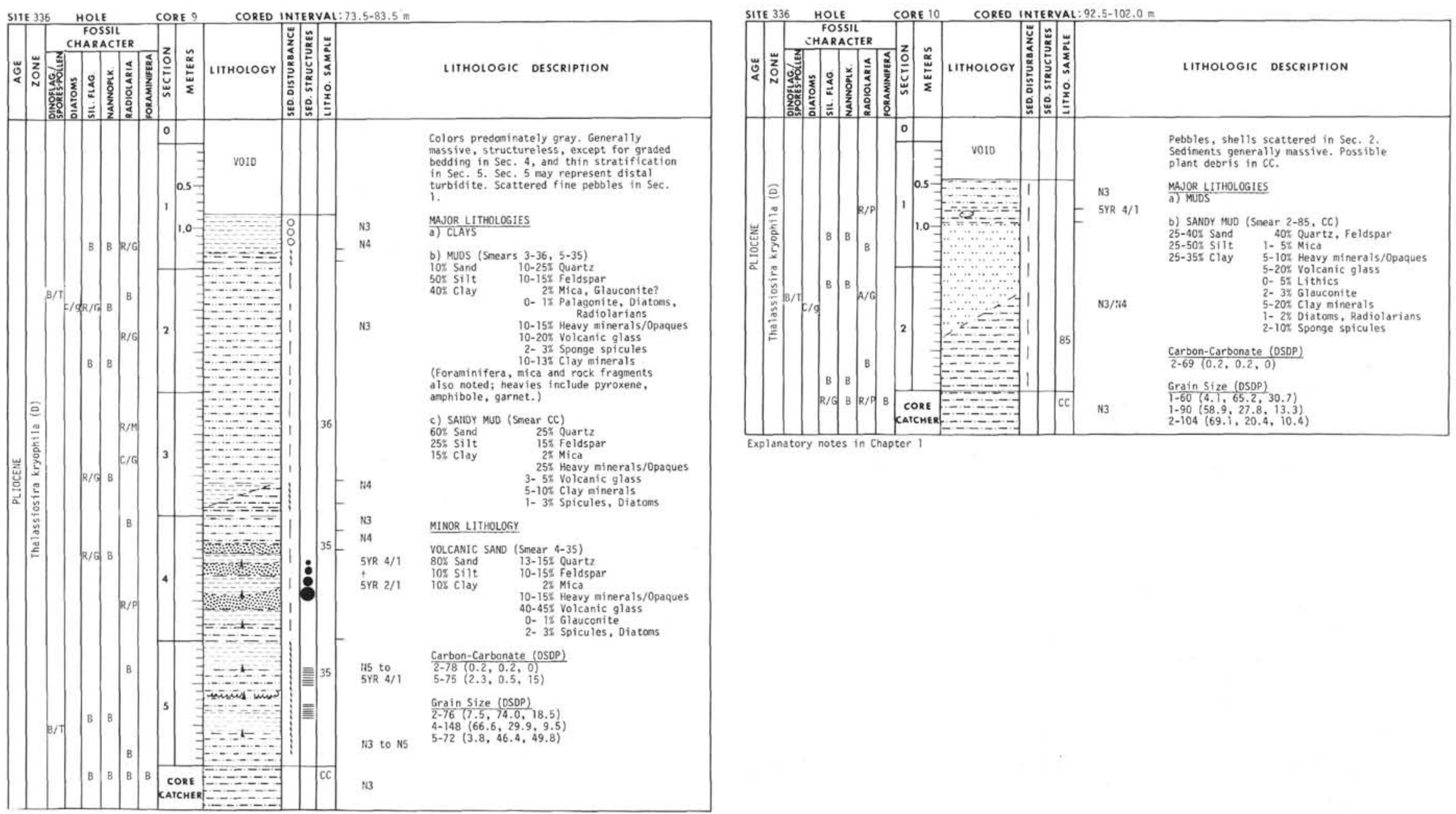
wrobidite. Scattered fine pebbles in sect.

MaJOR LITHOLOSIES 10-15x Heavy mi inerarals/0paques 10-20r volcanic glass
2.-3K S Foraminitifera mica and rock fragnents ibole, garnet.

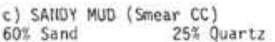
25\% Hicasy minerals/0paques Peboles, shetls scattered in sec., 2 . MAJOR LITHOLOGIES

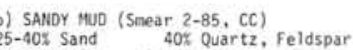
25-50\% sitt 1-55 Micd

5-20\% clay minera:

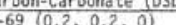

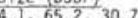
$-90,58.9,27.8 .813 .3)$
$-104(69, i, 20.4,10.4)$ 


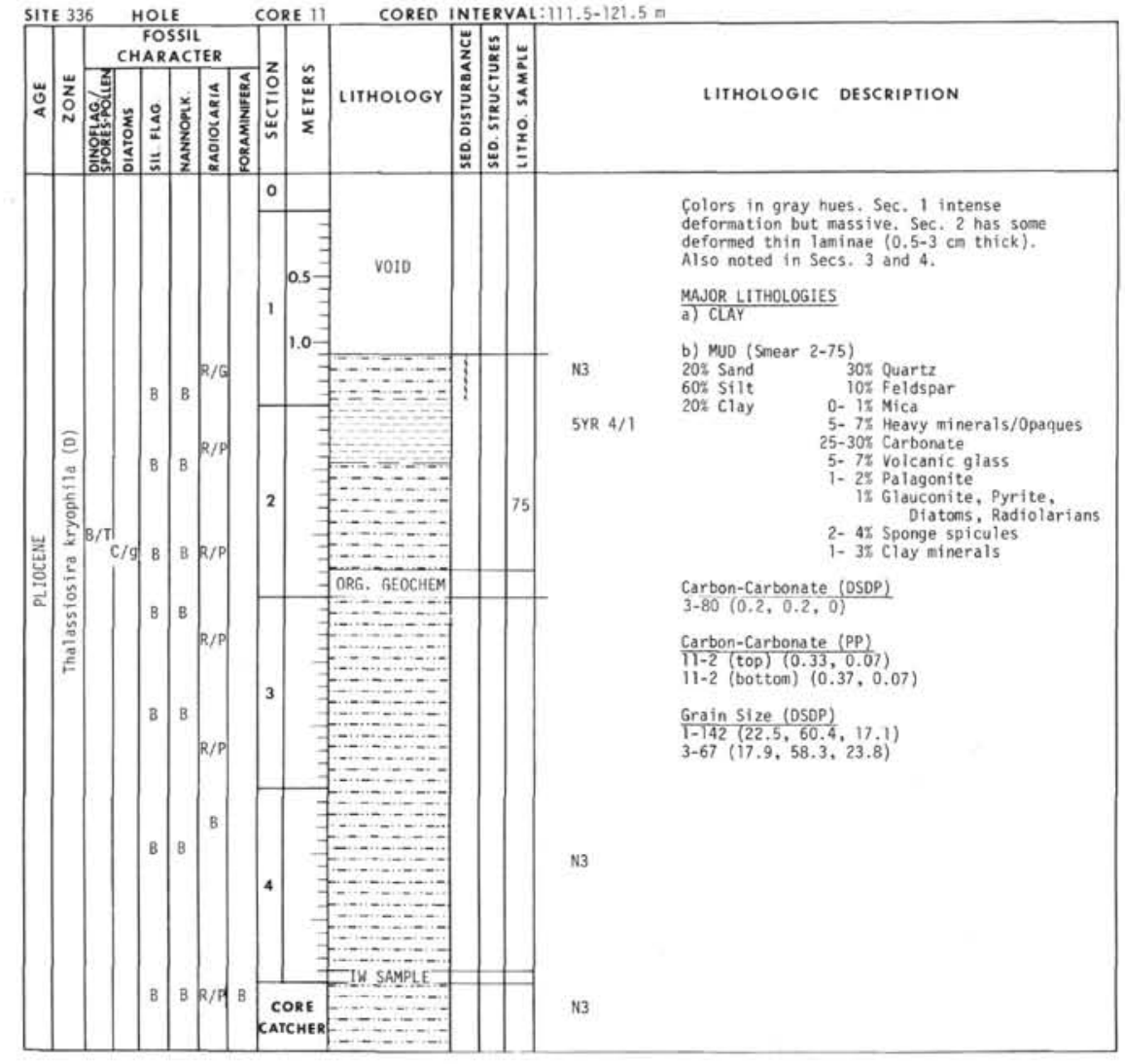

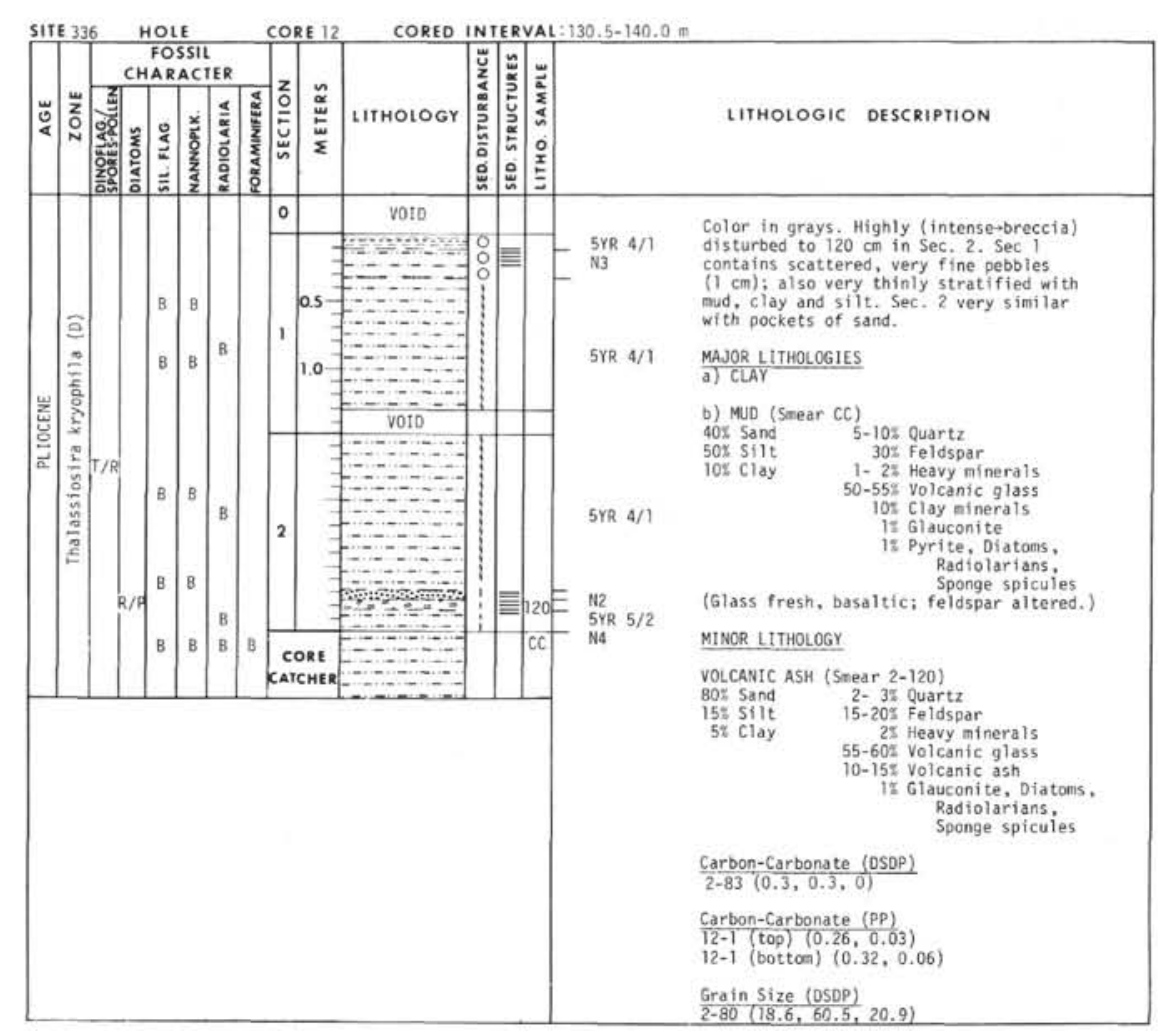

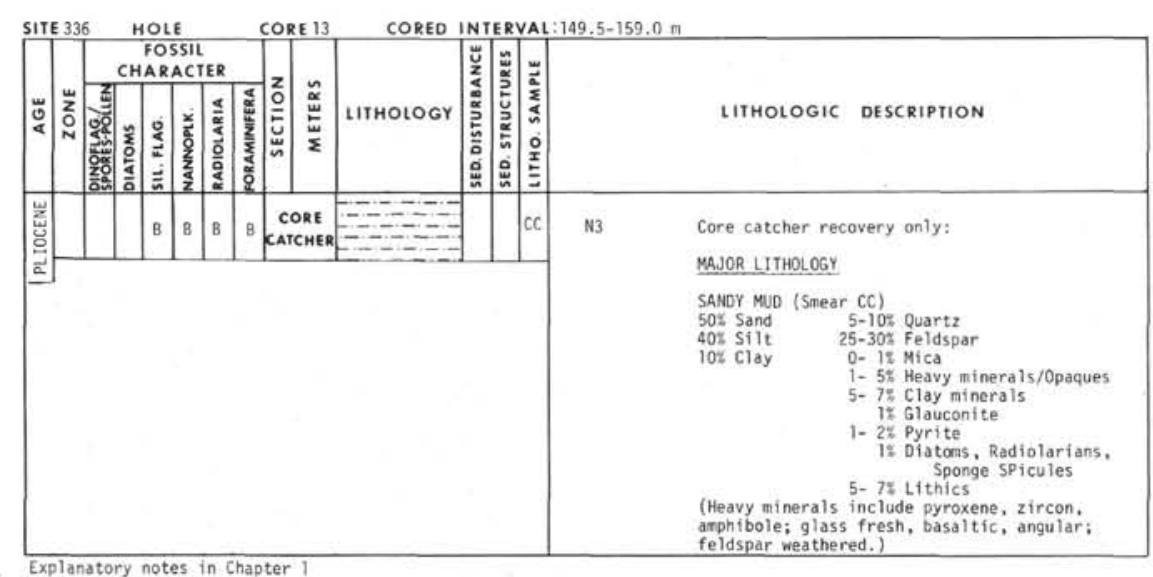



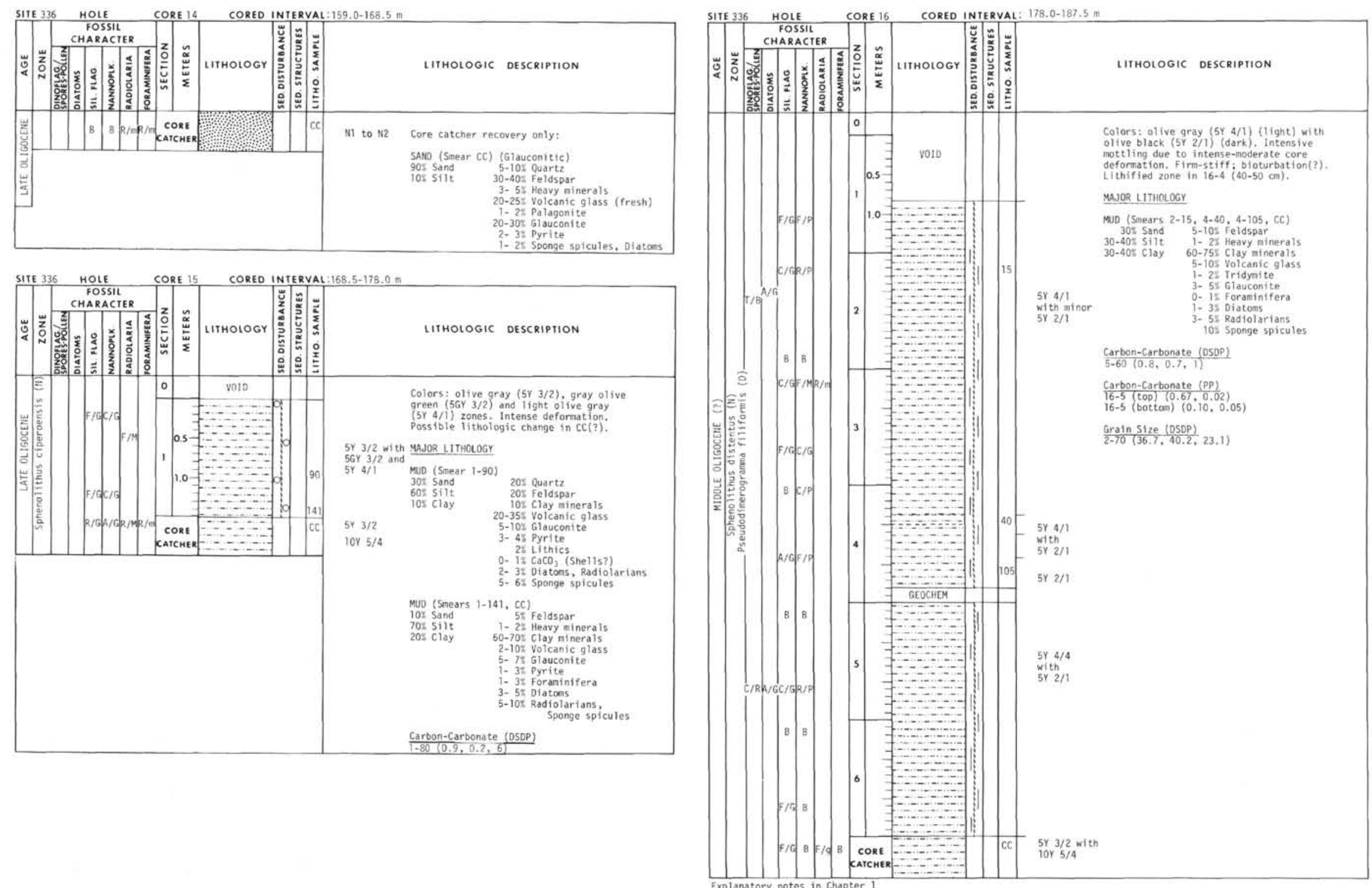

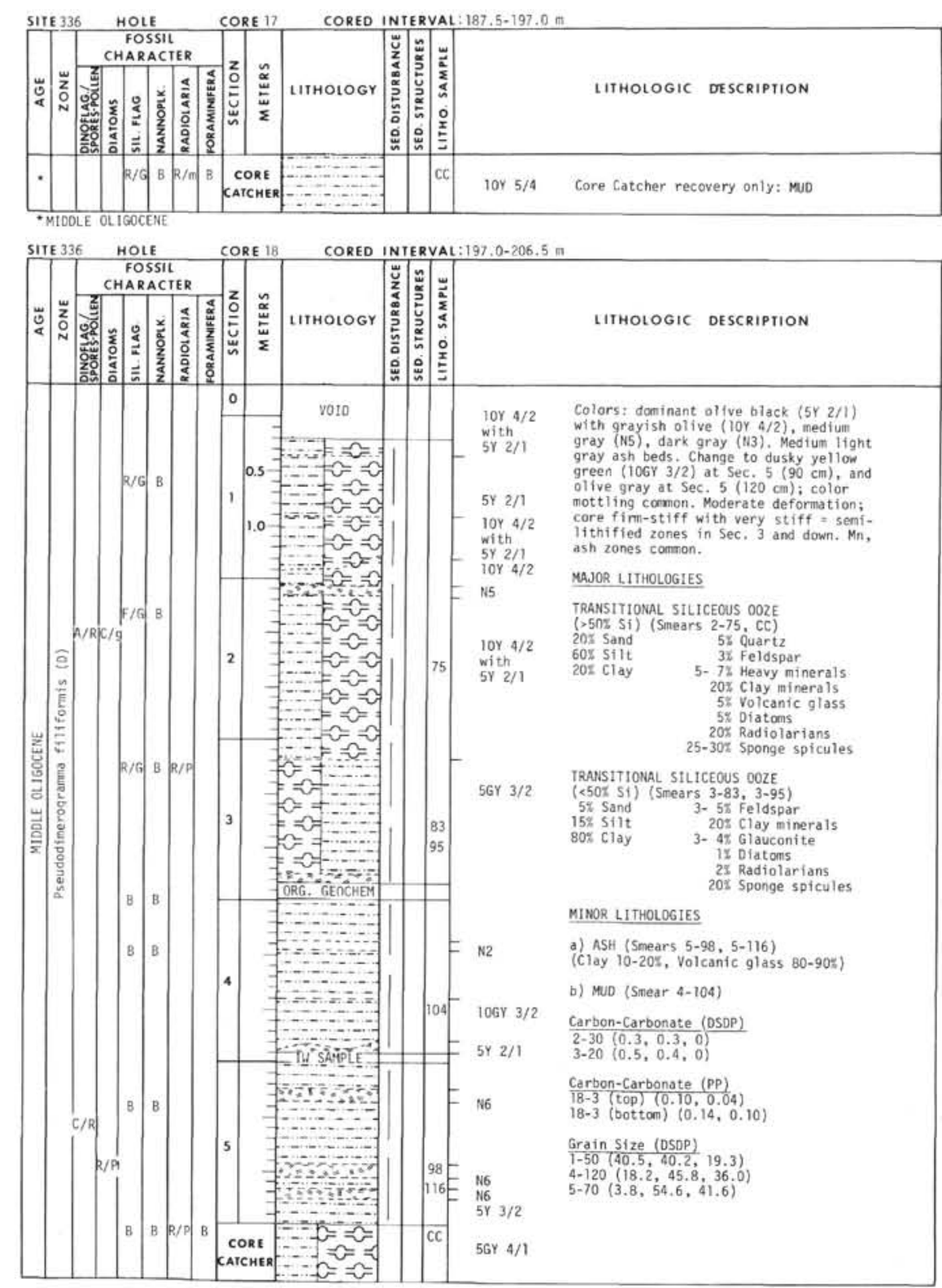

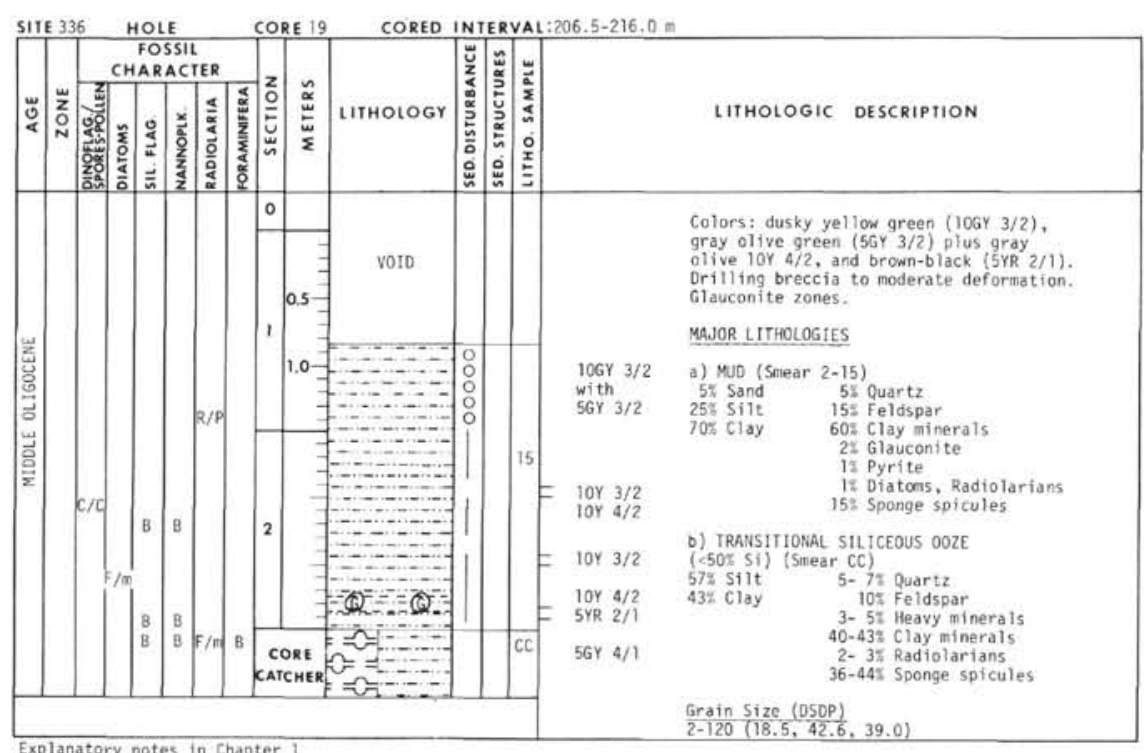

Explanatory notes in chapter

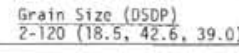



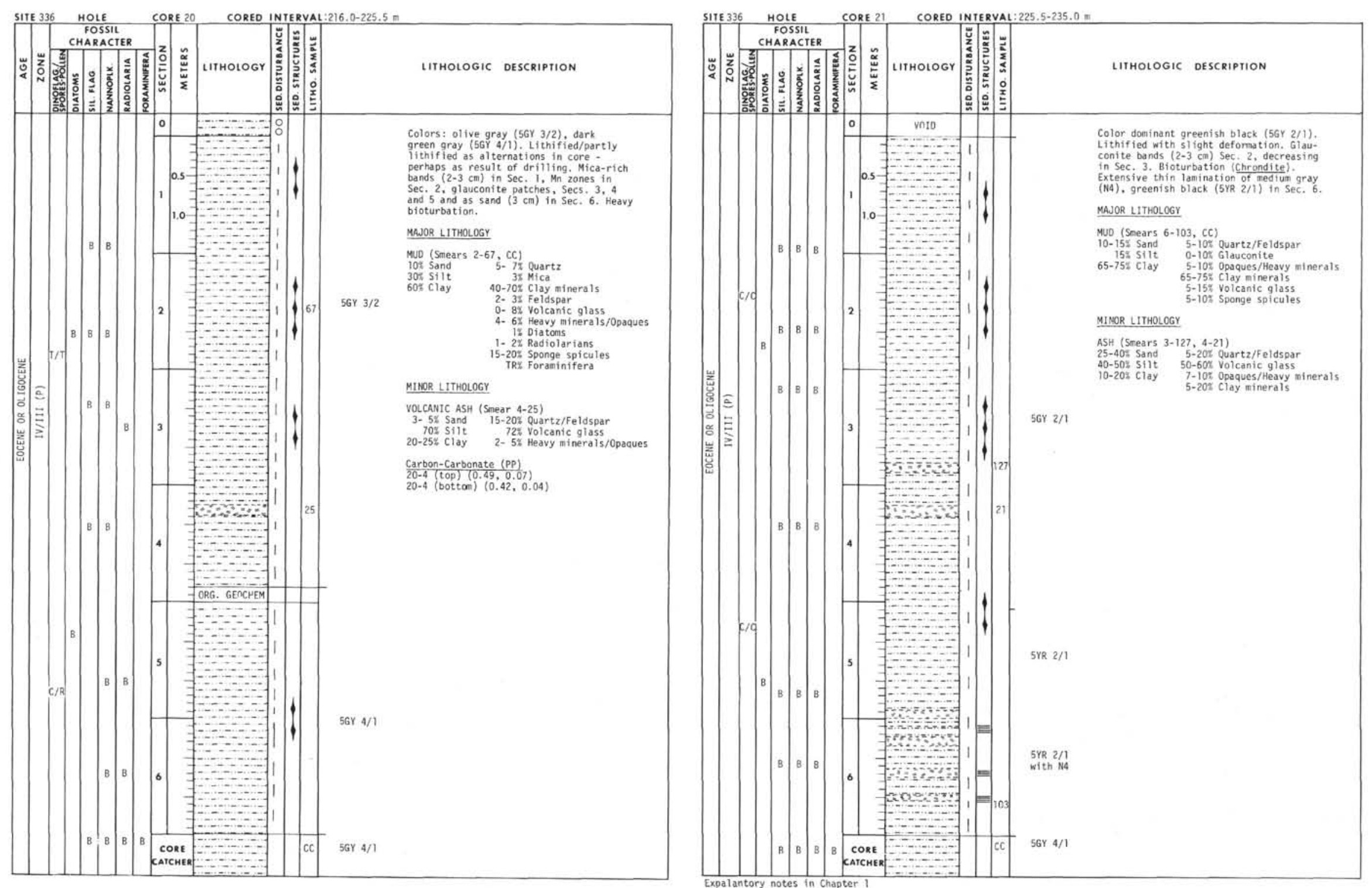

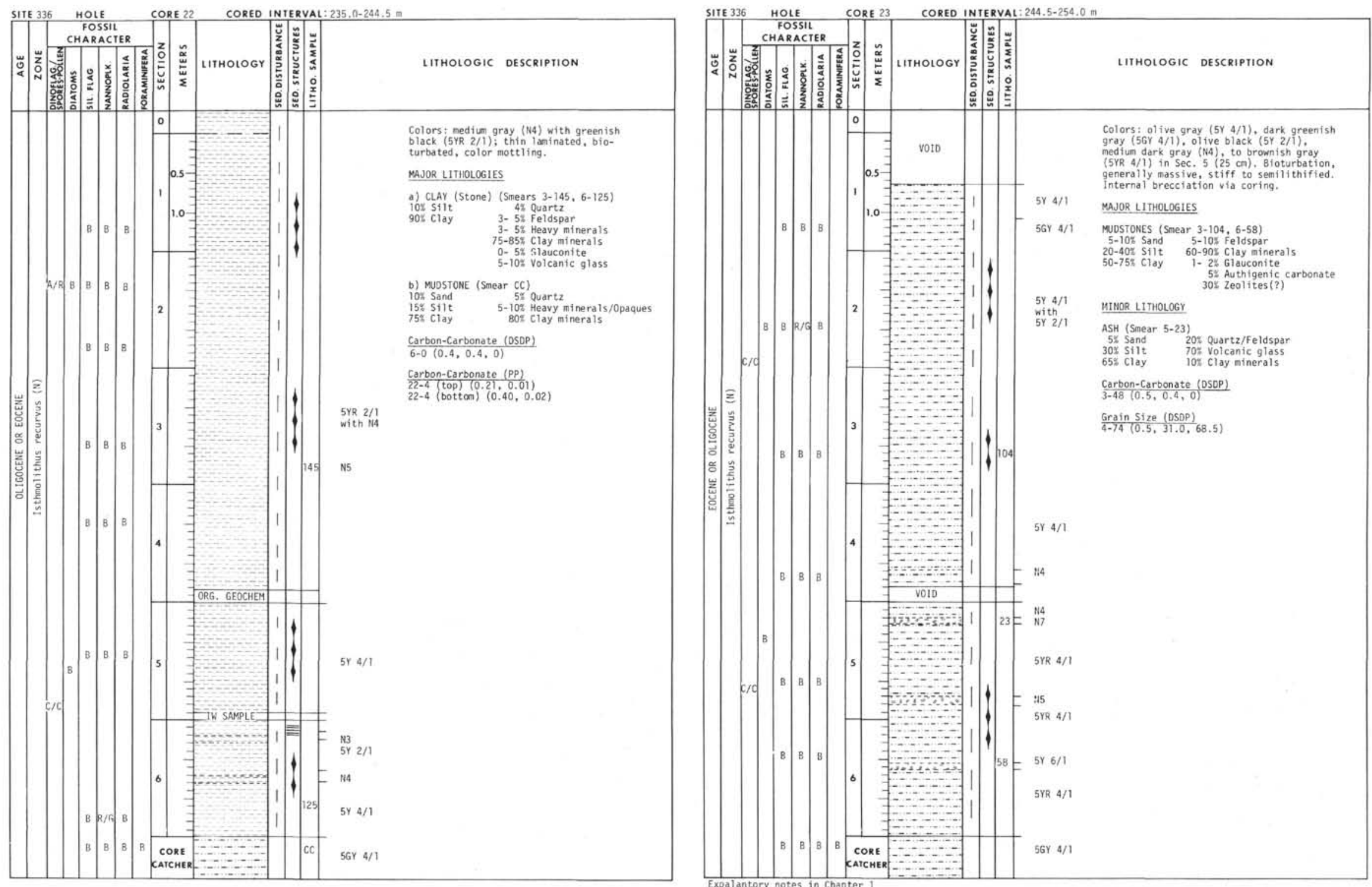

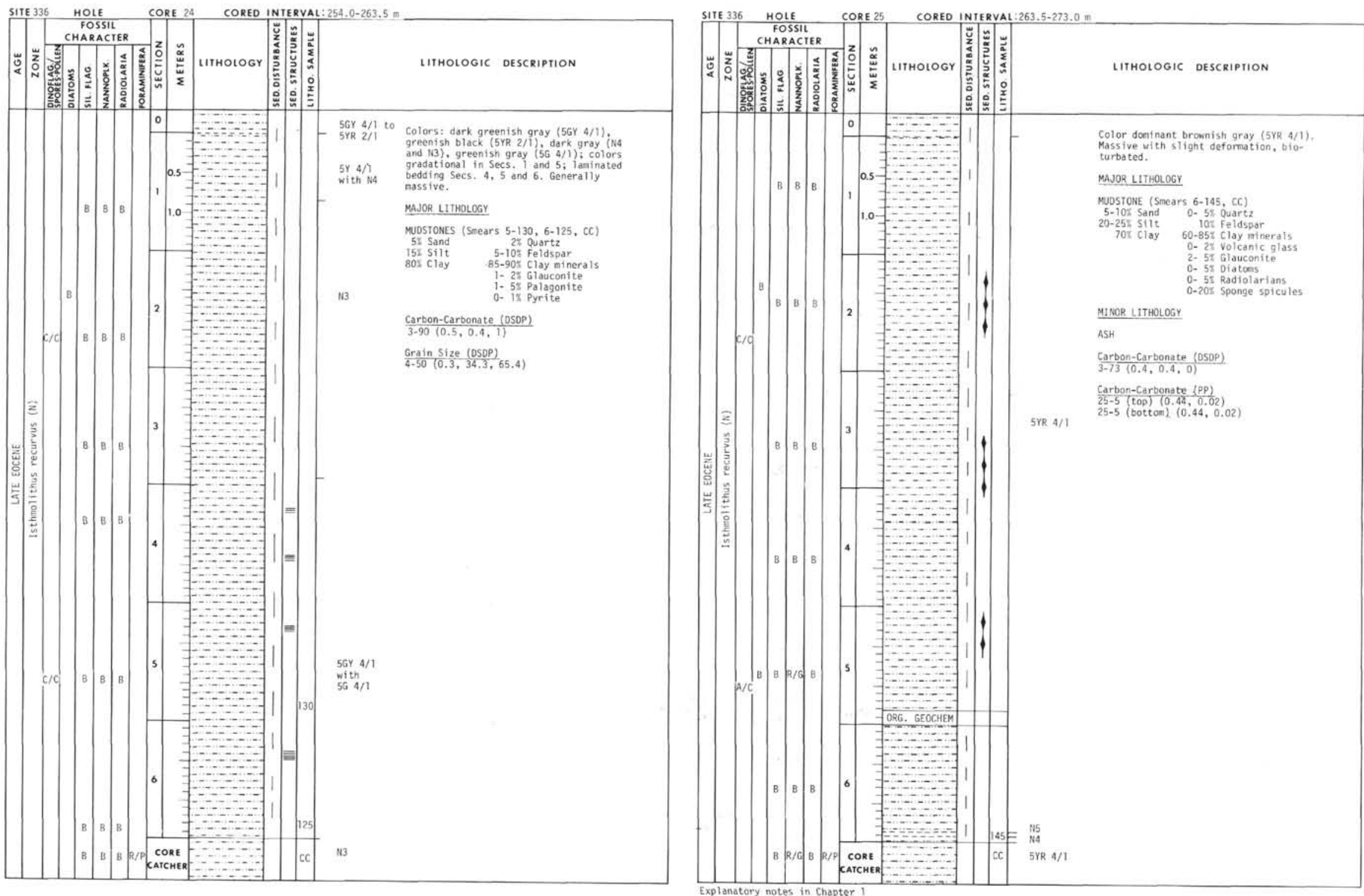

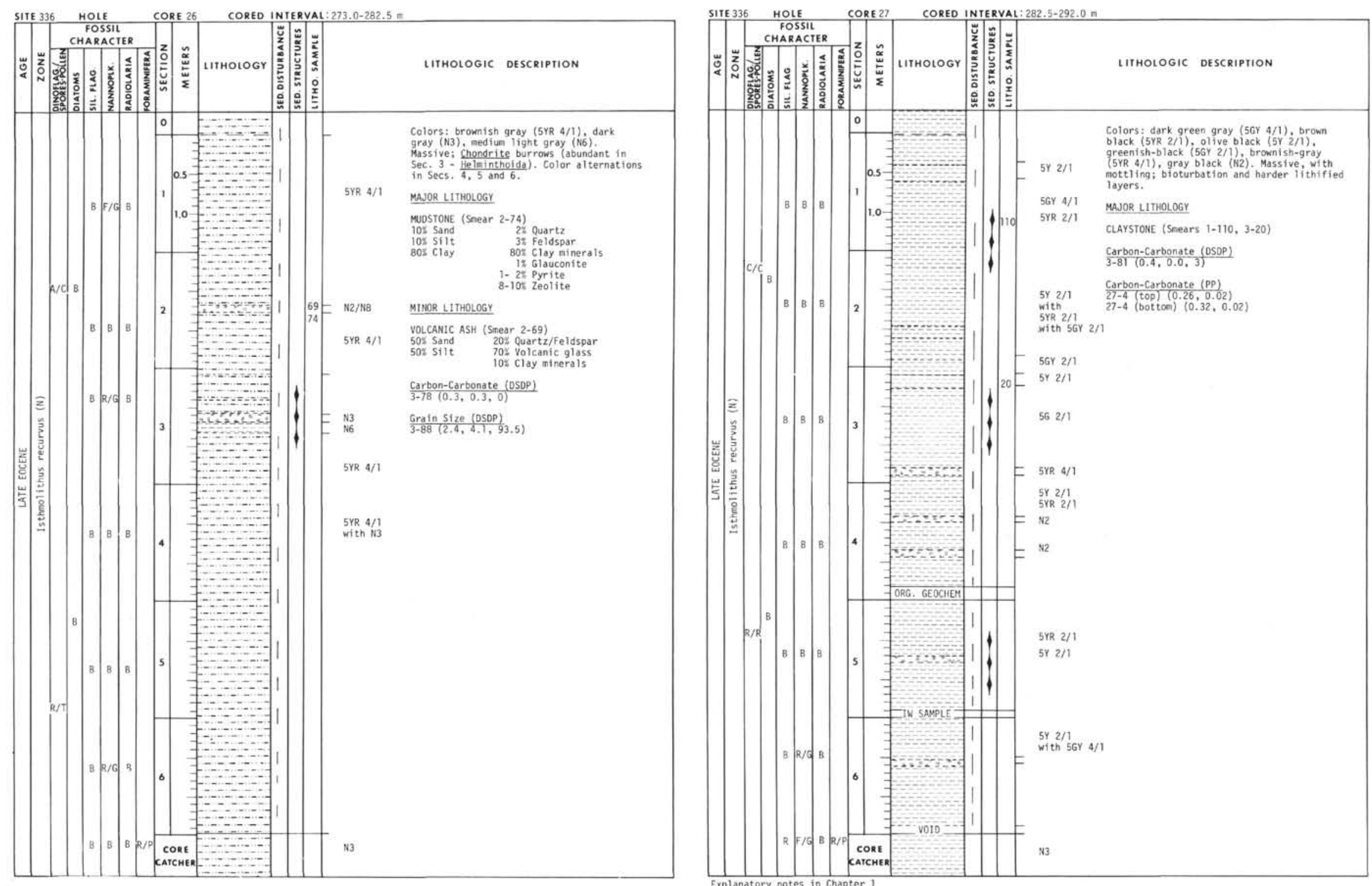

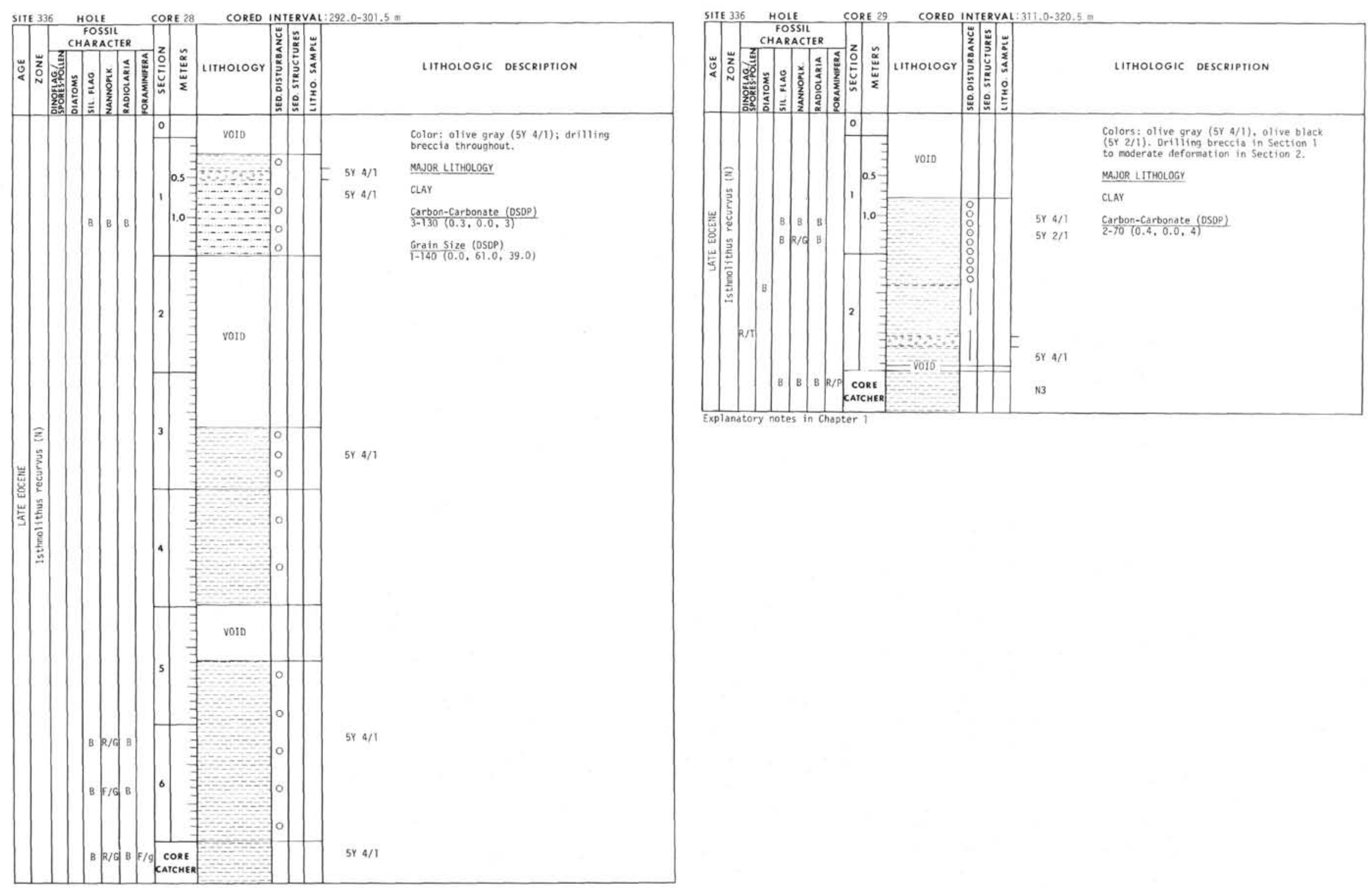


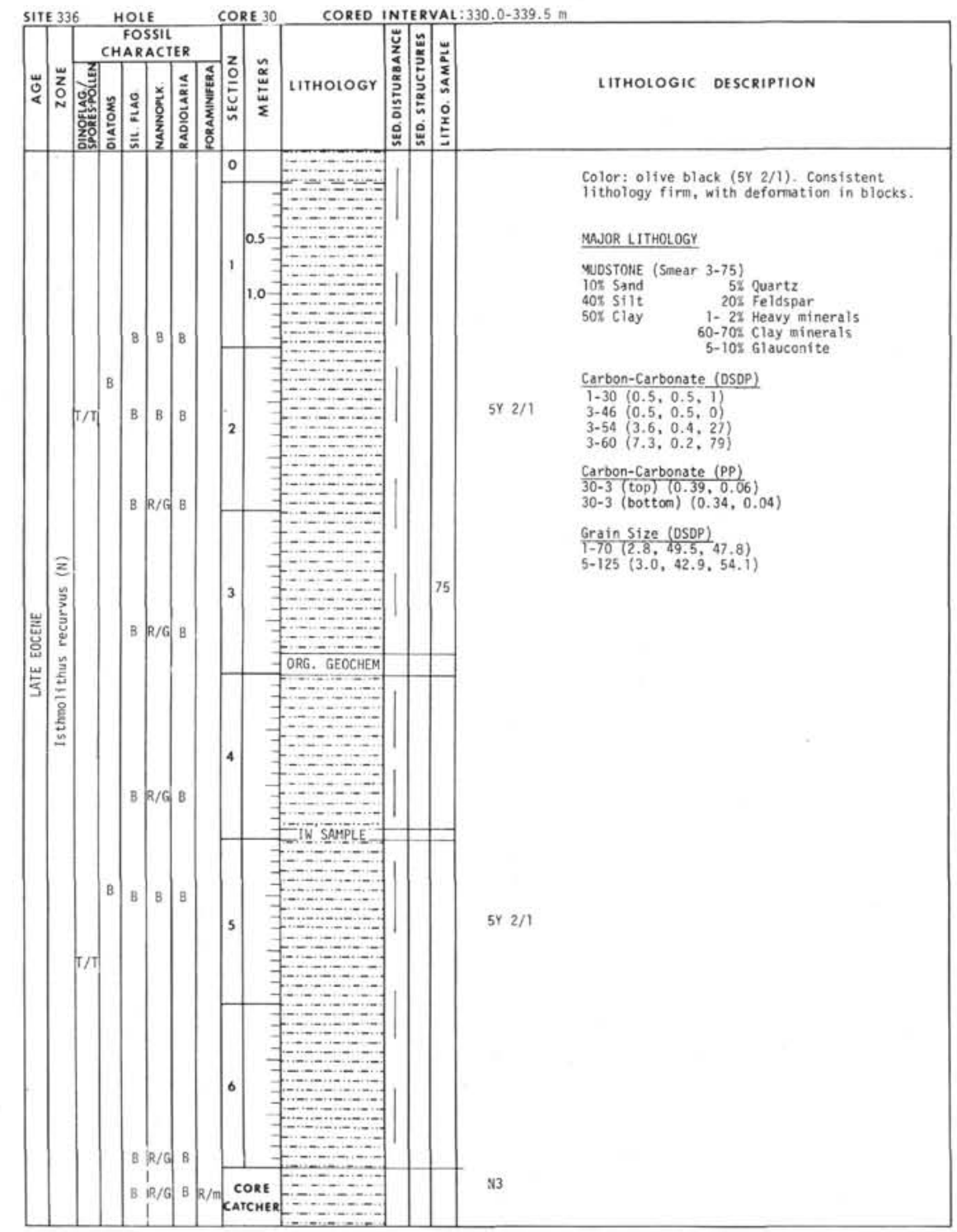

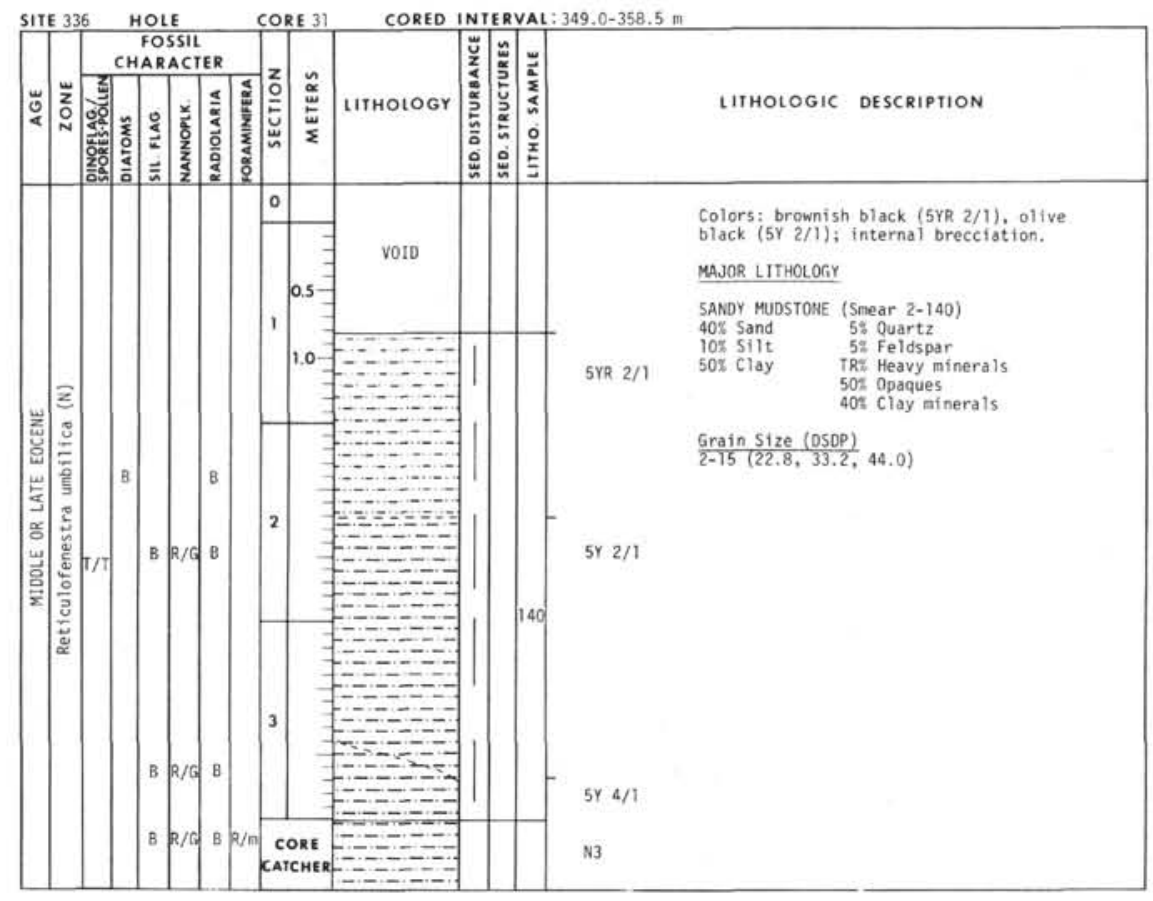

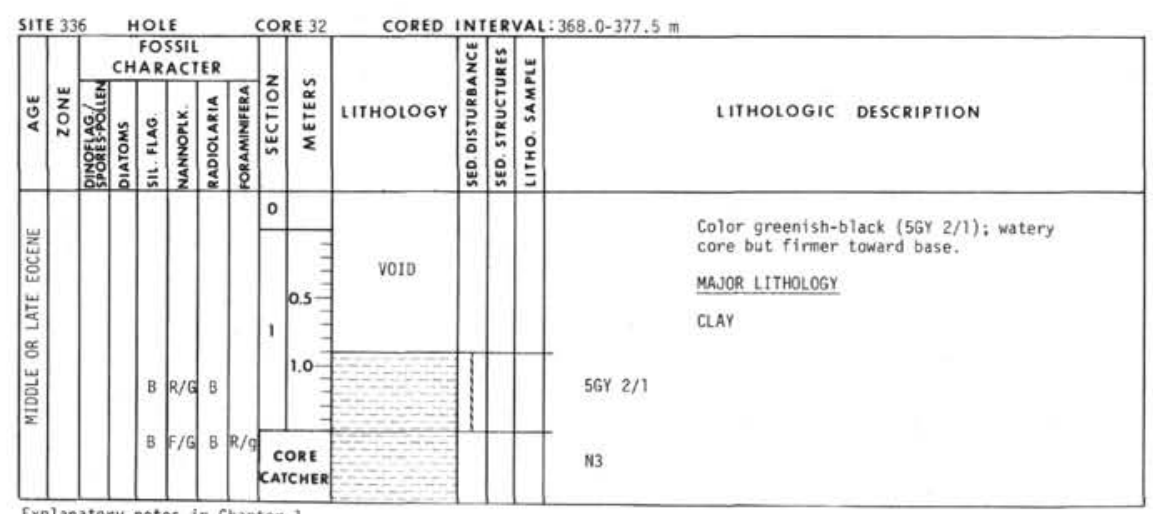



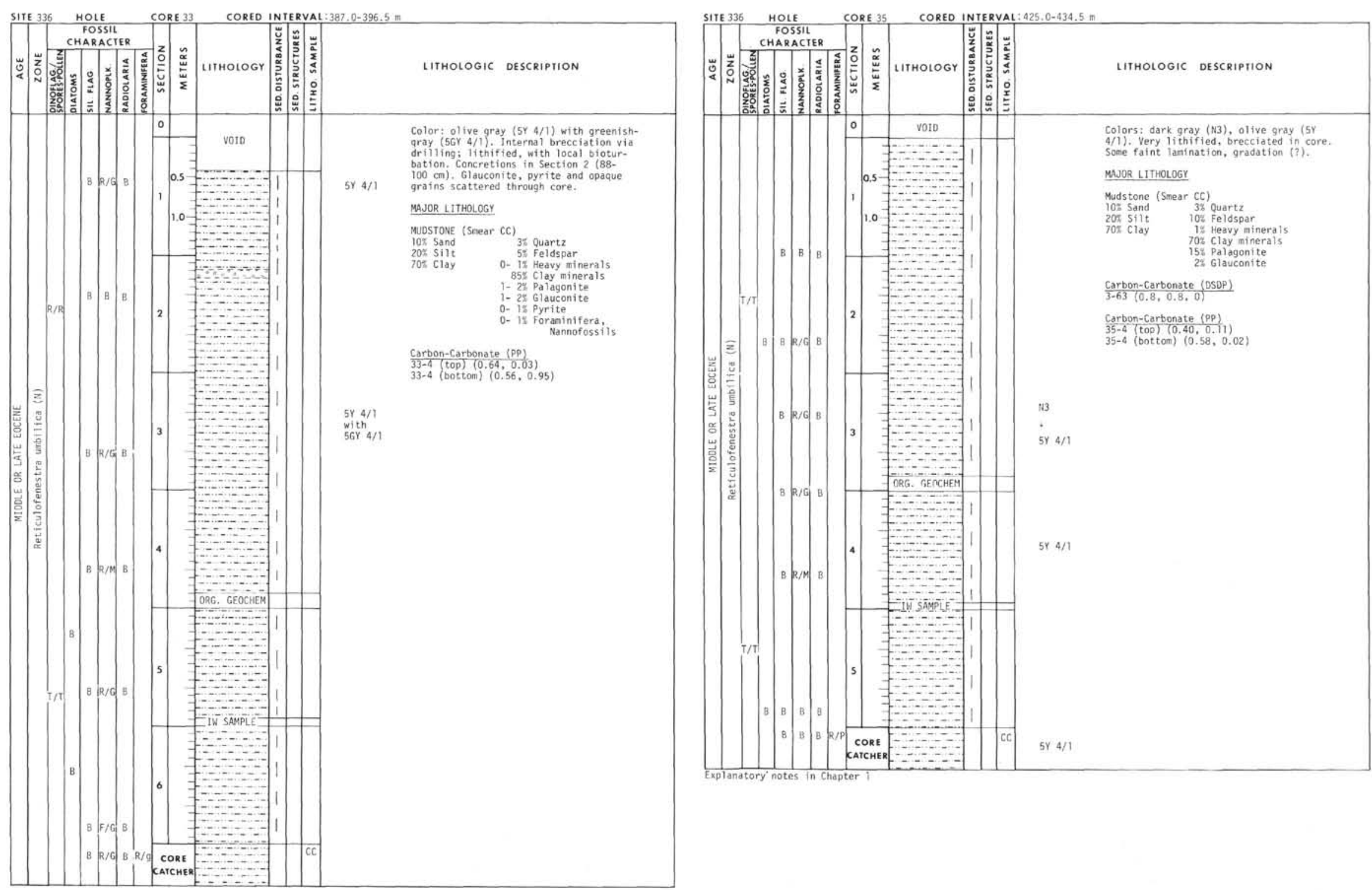


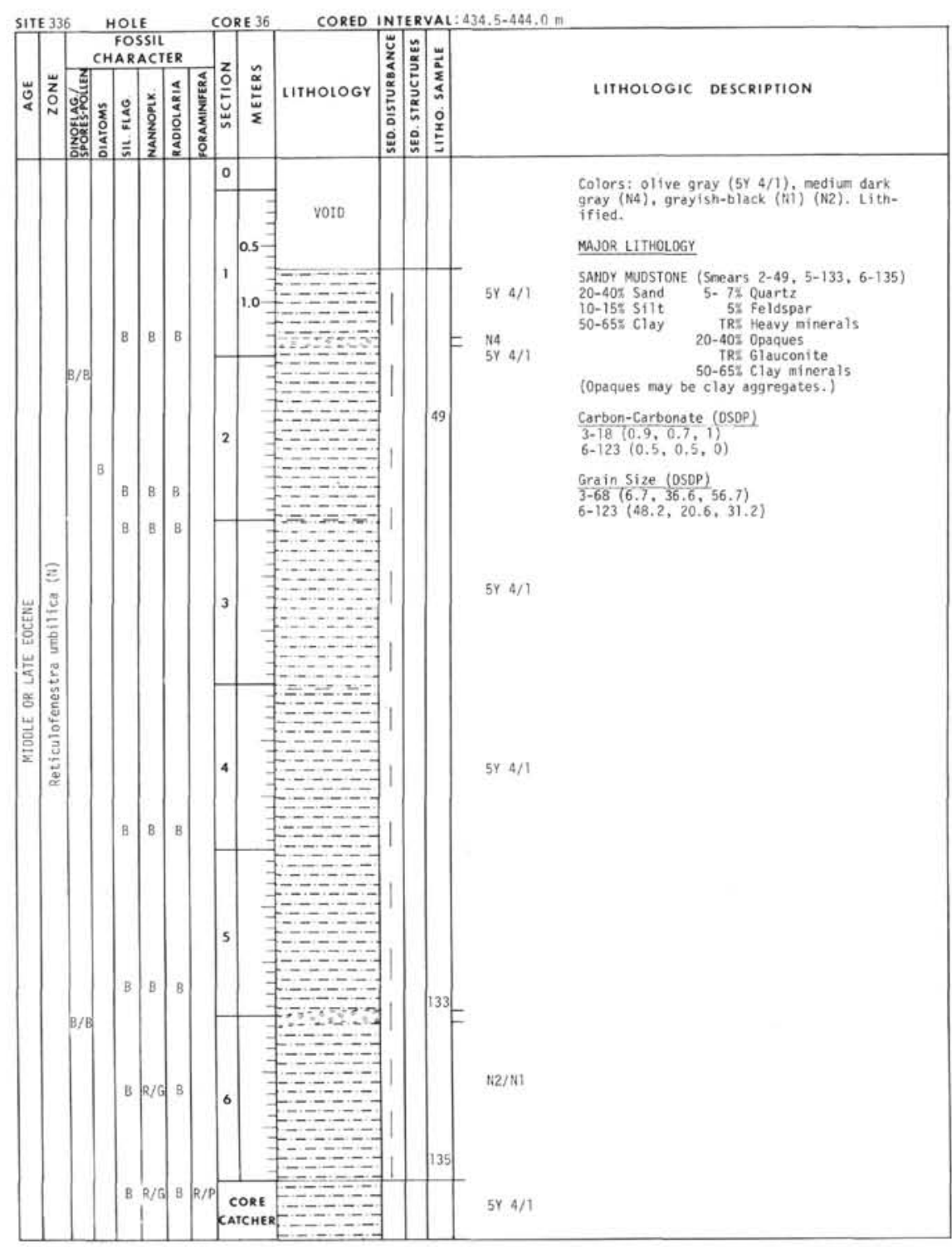

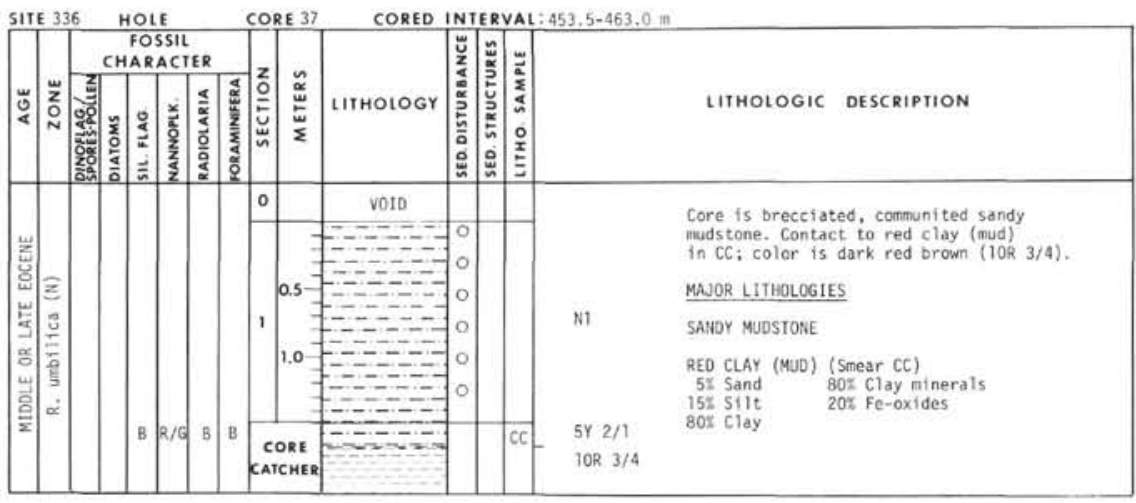

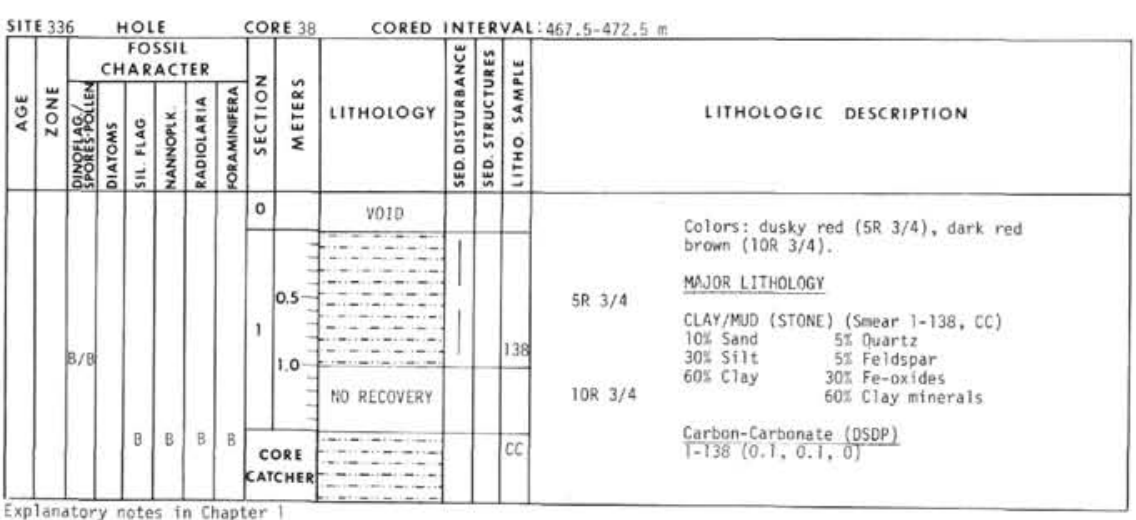


g

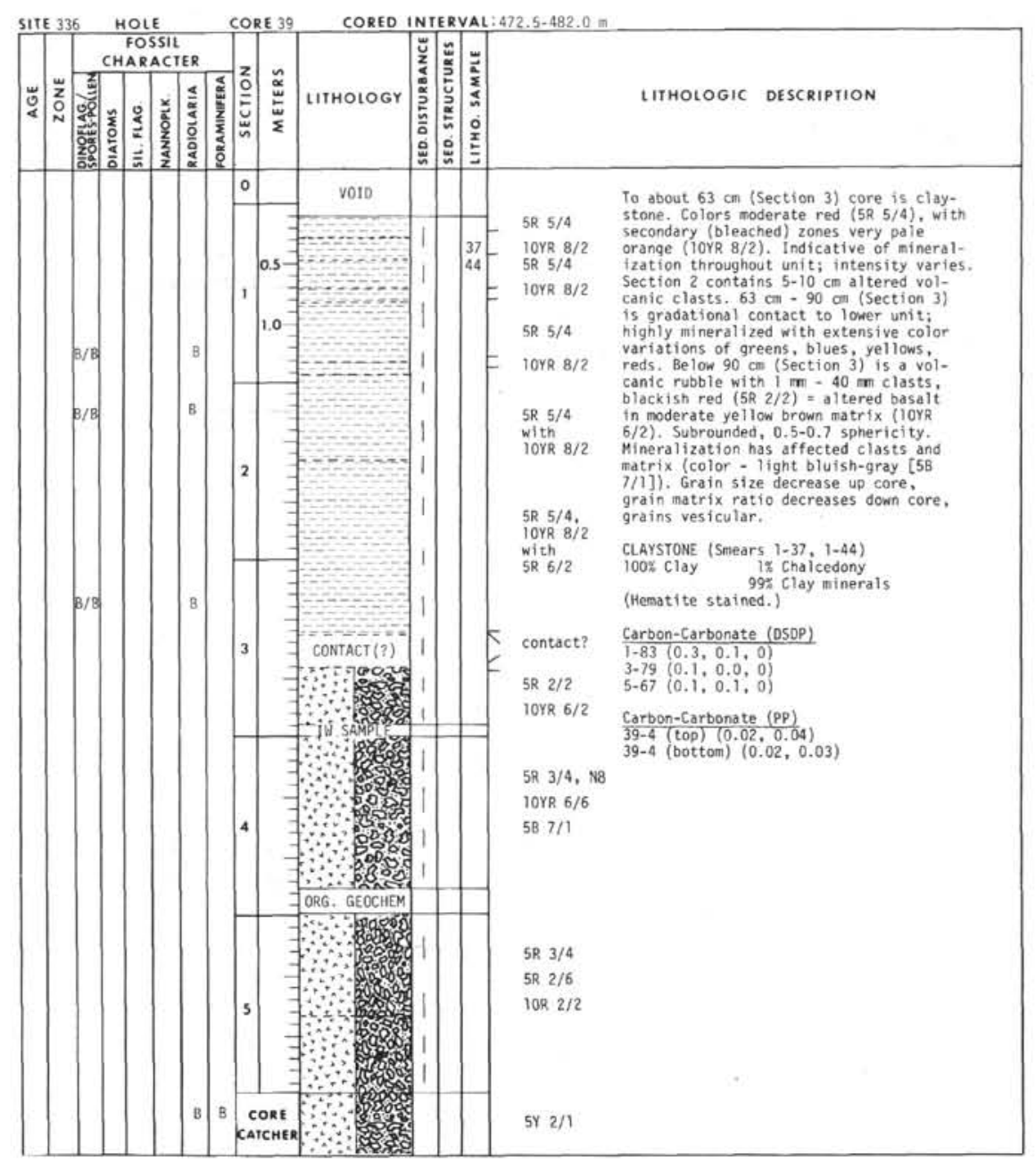

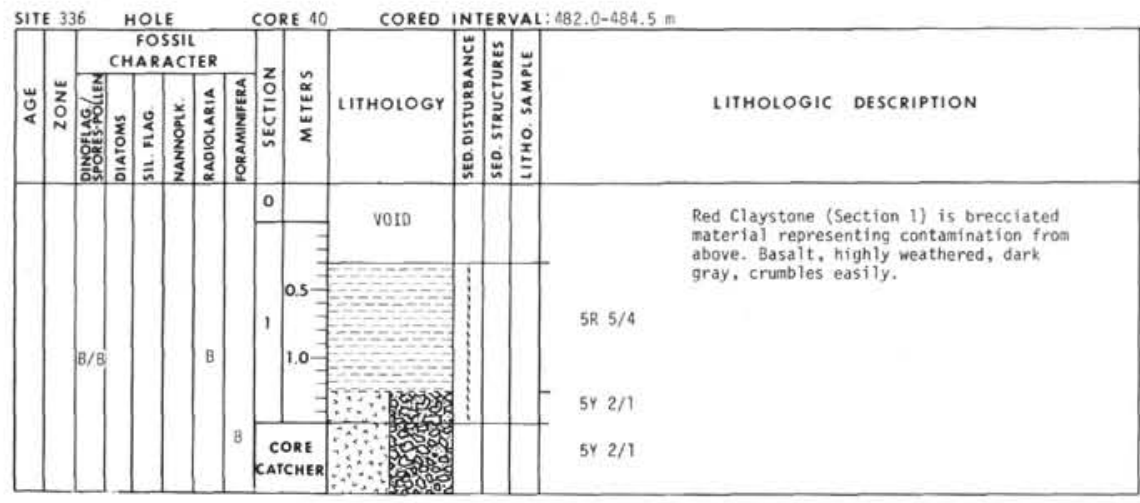

\begin{tabular}{|l|l|l|l|l|l|l|l|l|}
\hline SITE 336 HOLE & COSSIL \\
\hline
\end{tabular}

Explanatory notes in Chapter 1 


\begin{tabular}{|l|l|l|l|l|l|l|l|l|}
\hline SIIE 336 HOLE & FOSSIL \\
\hline
\end{tabular}

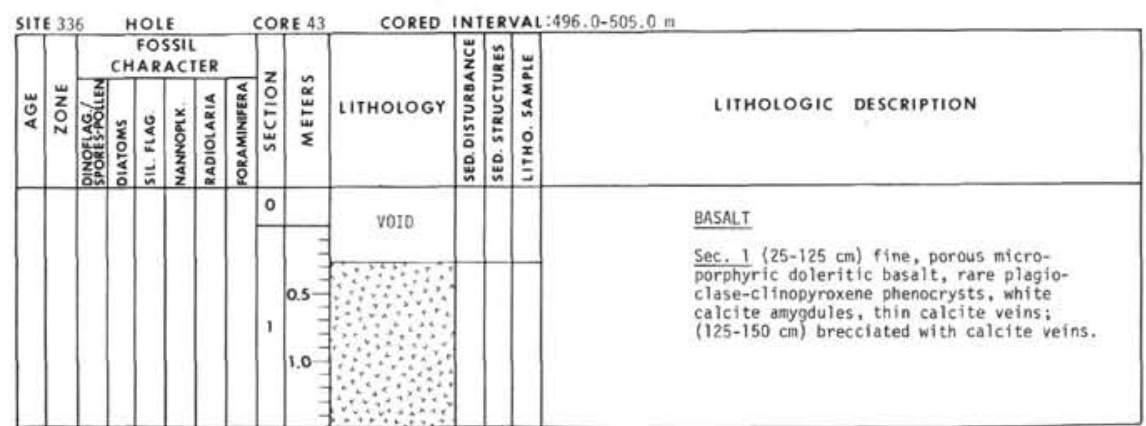

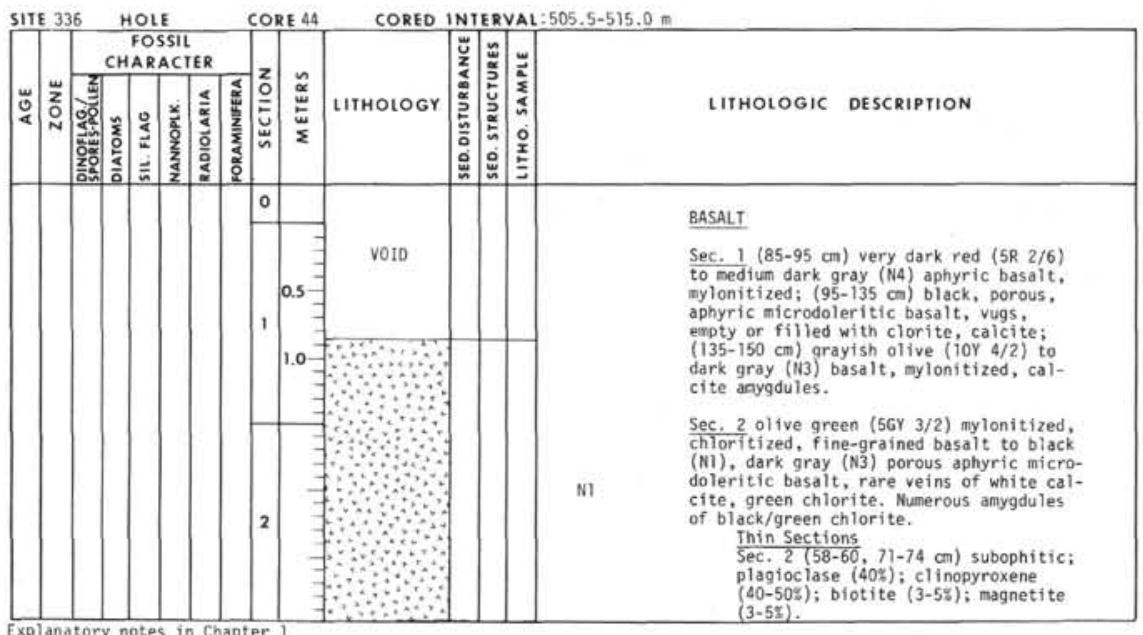




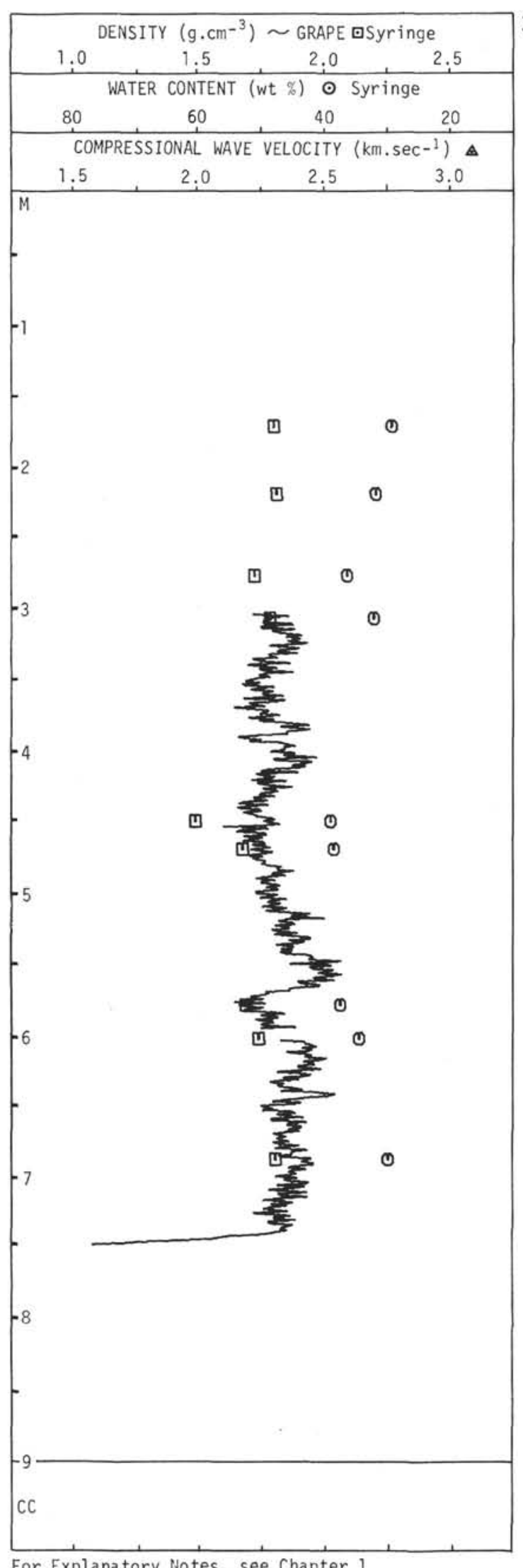

336- 1

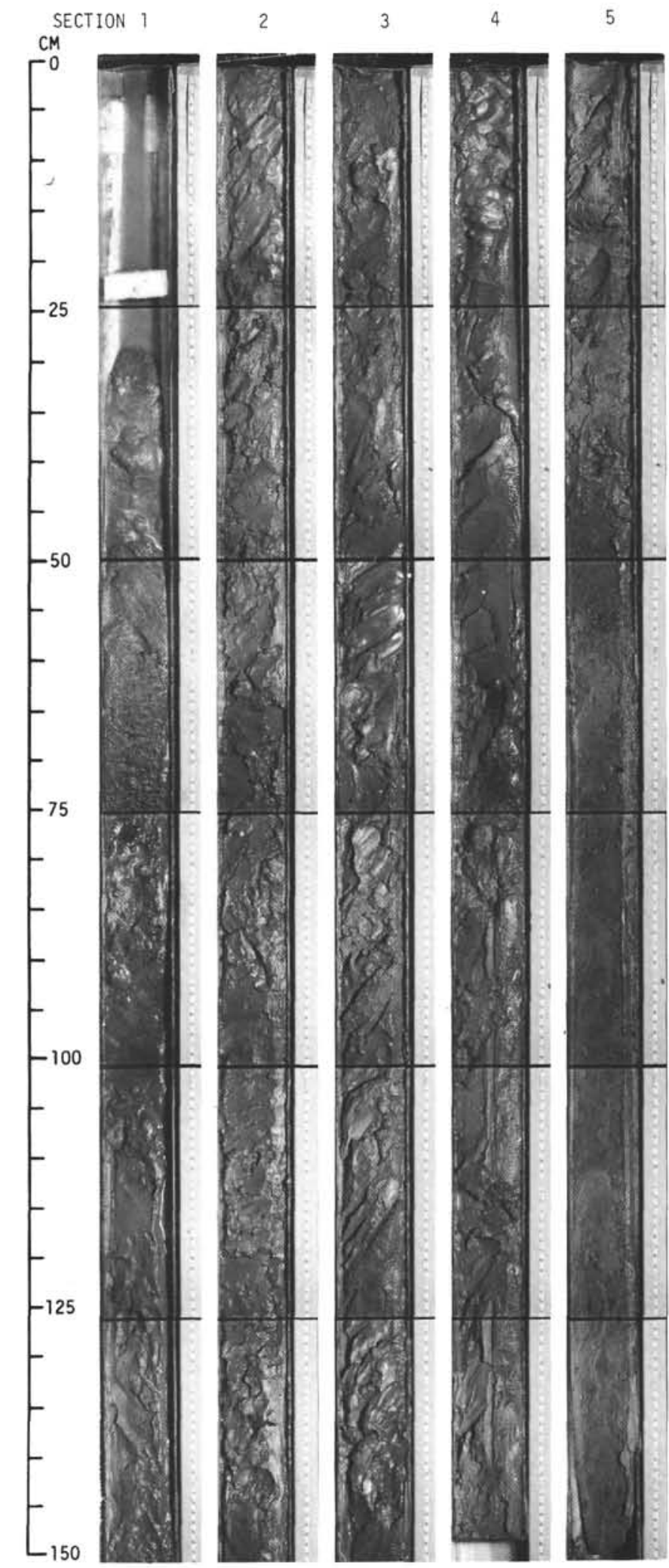




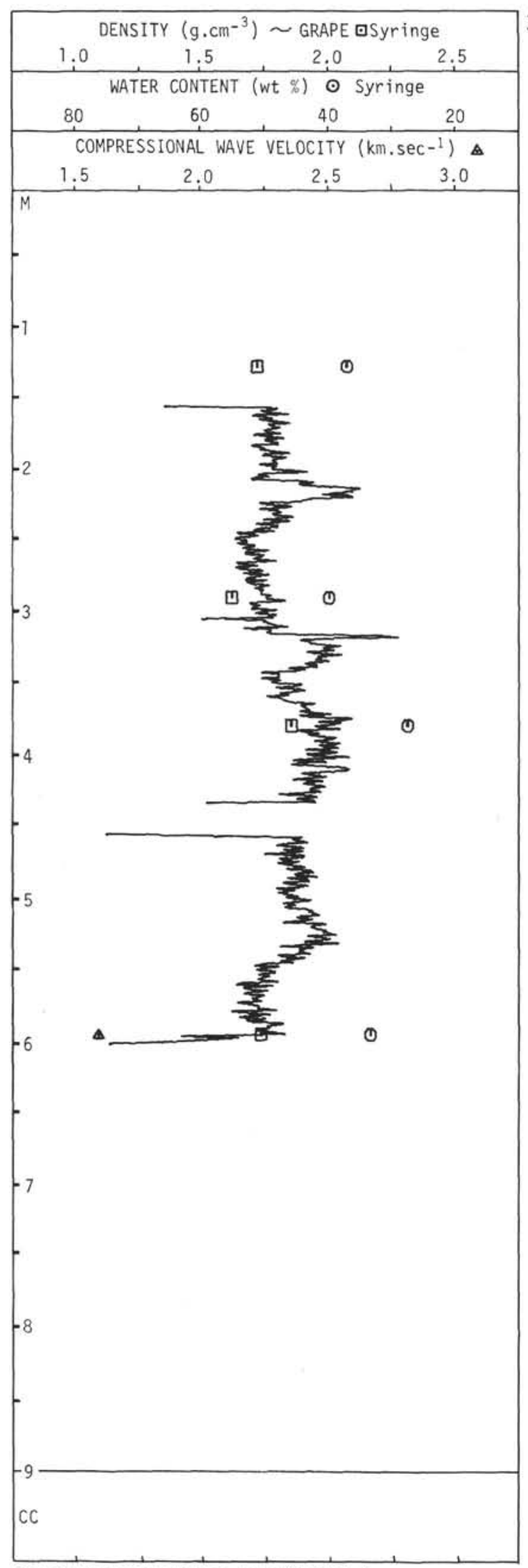

$336-2$

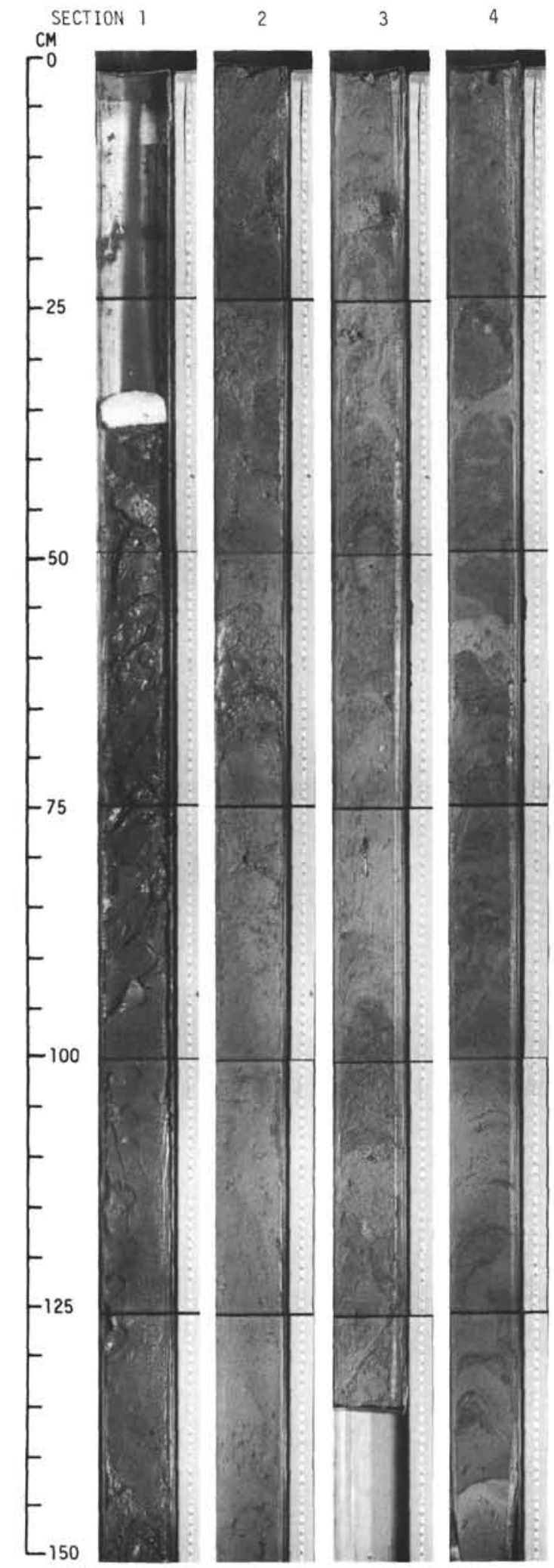




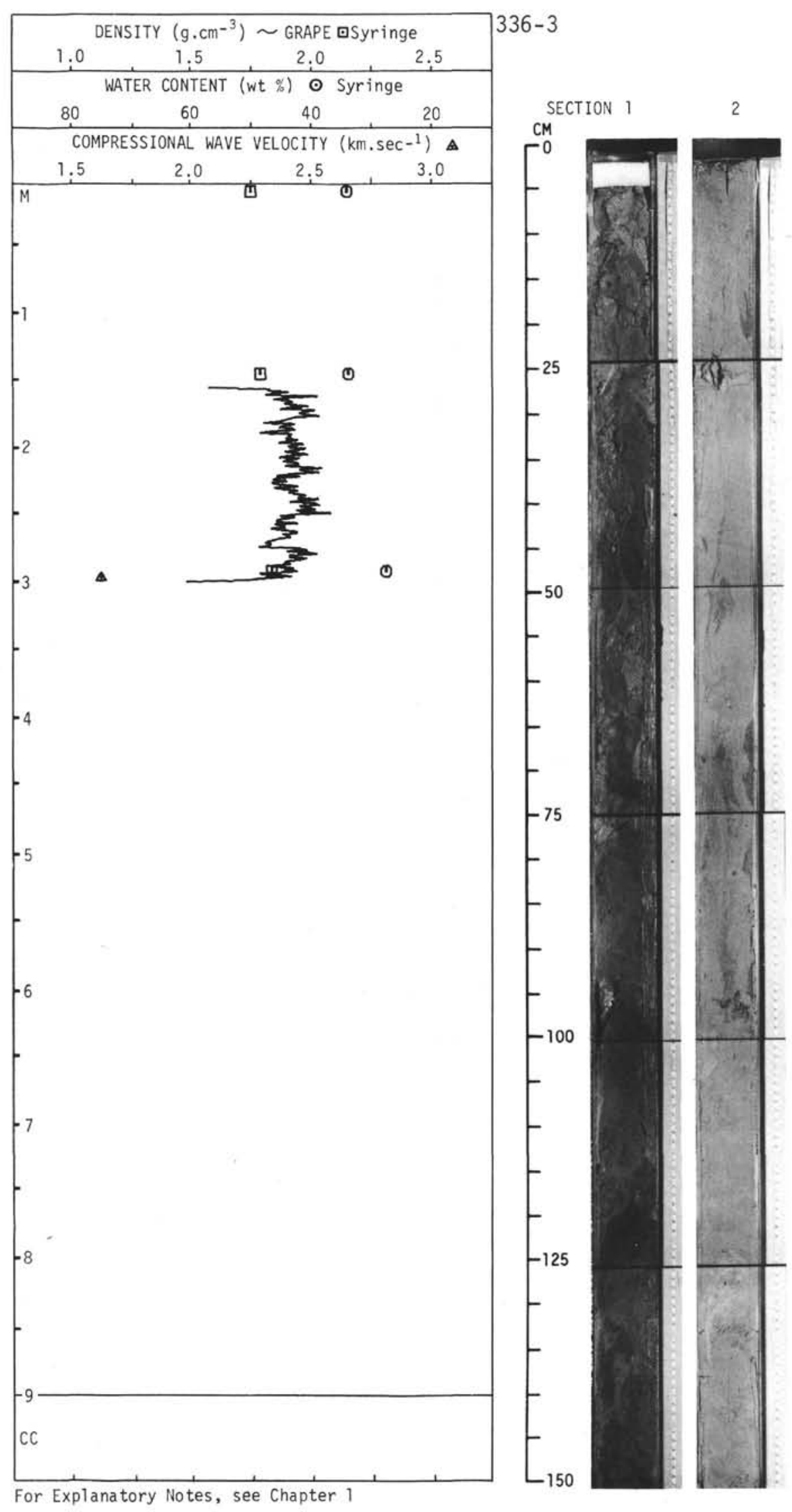




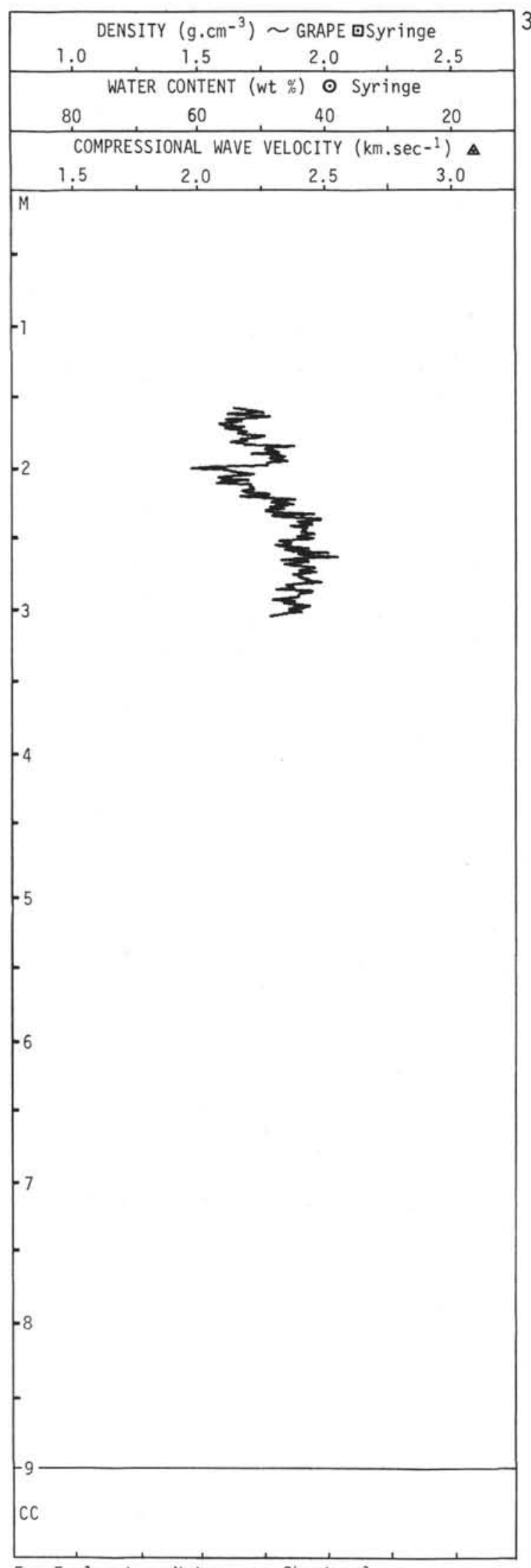

$336-4$

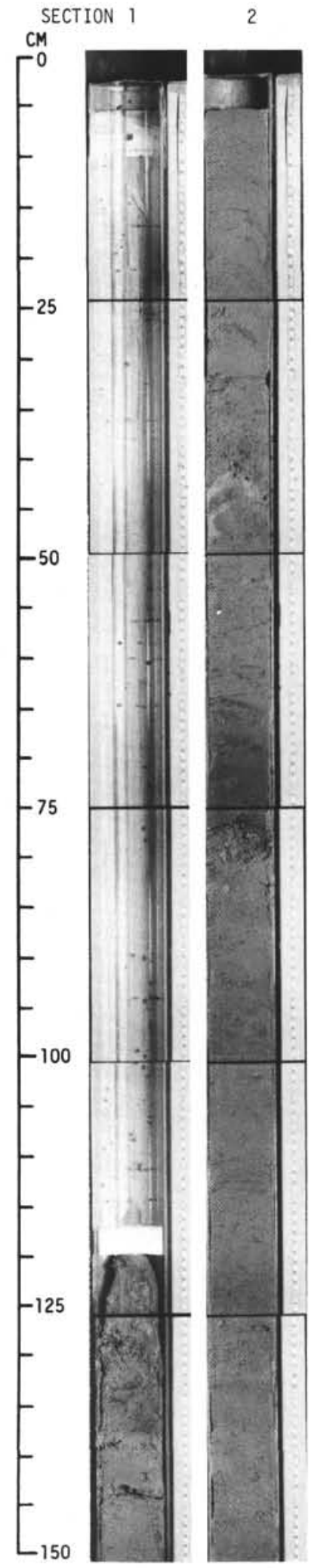




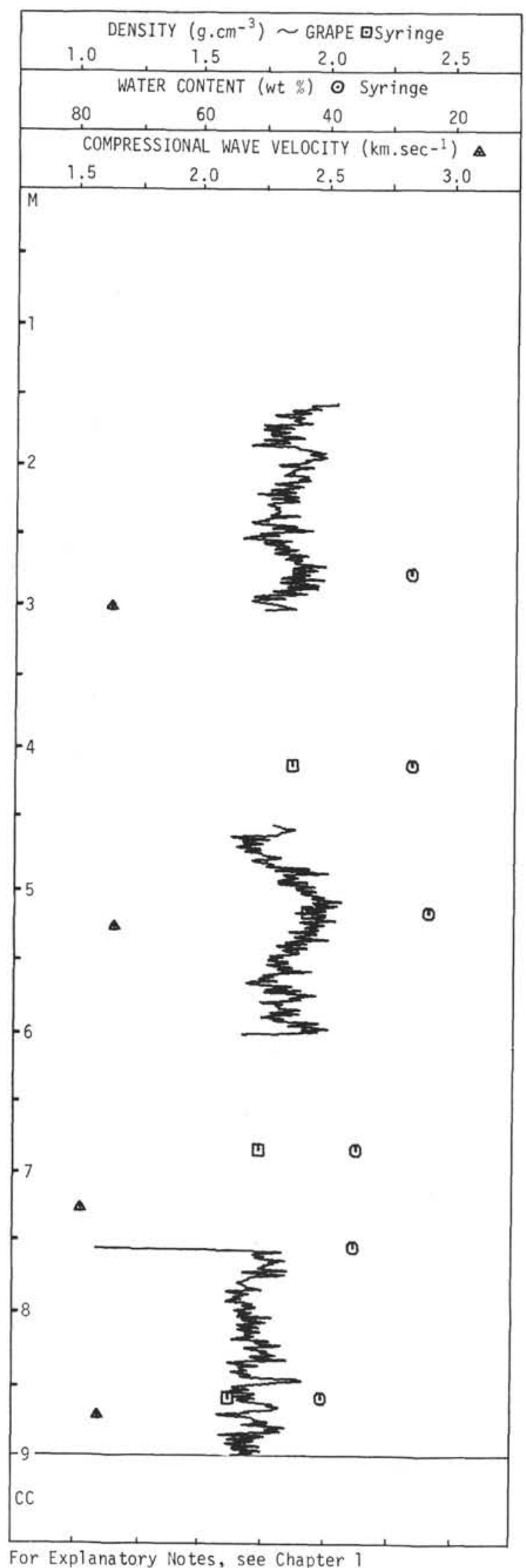

336-5

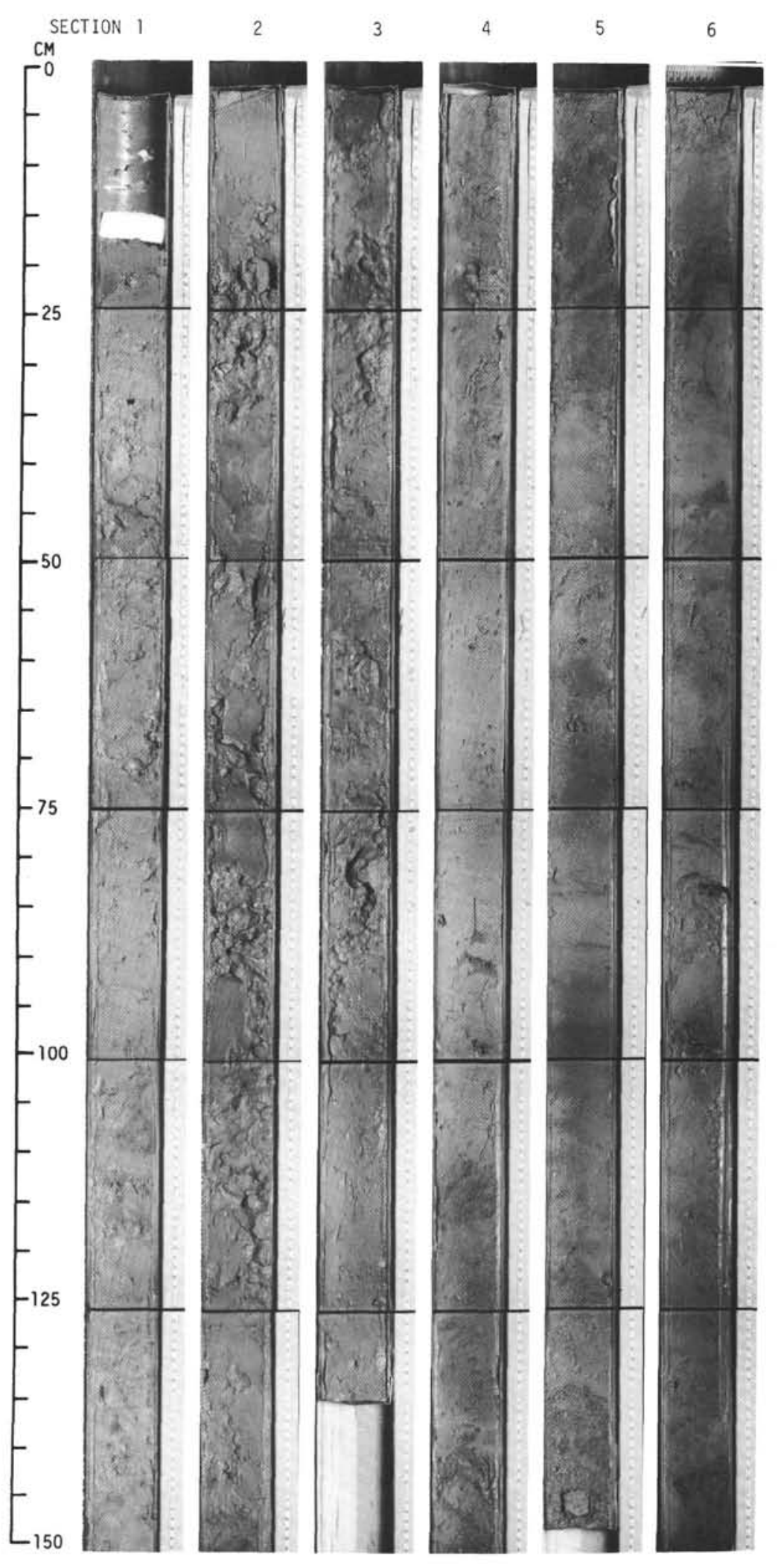




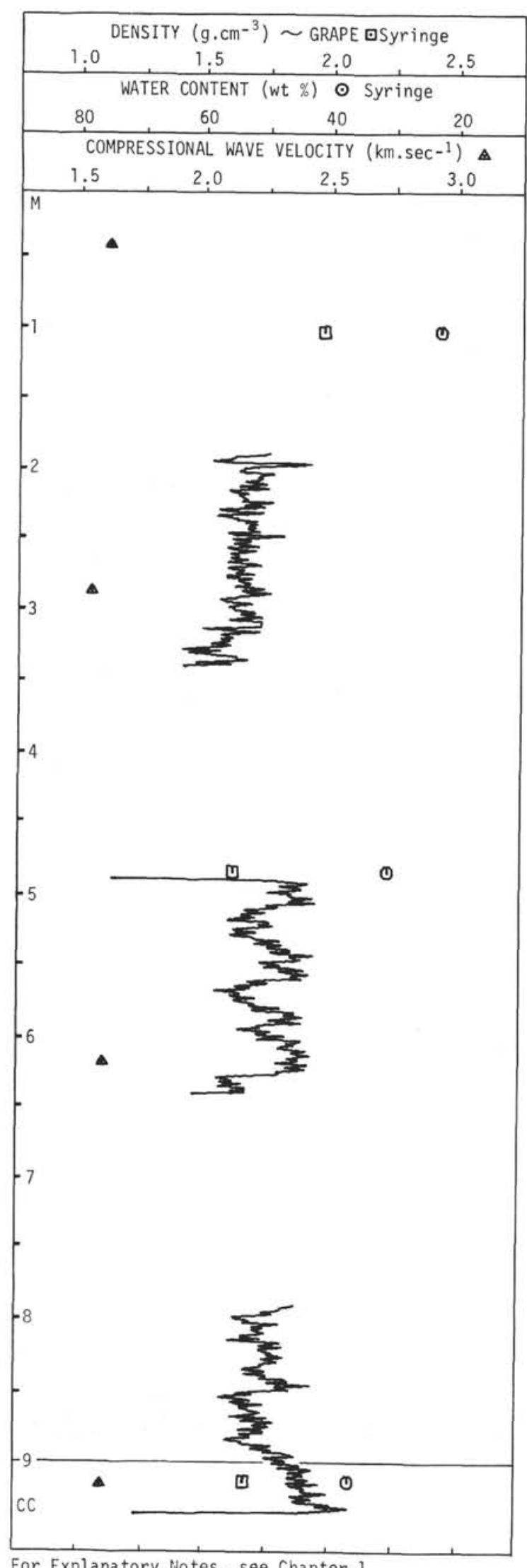

$336-6$

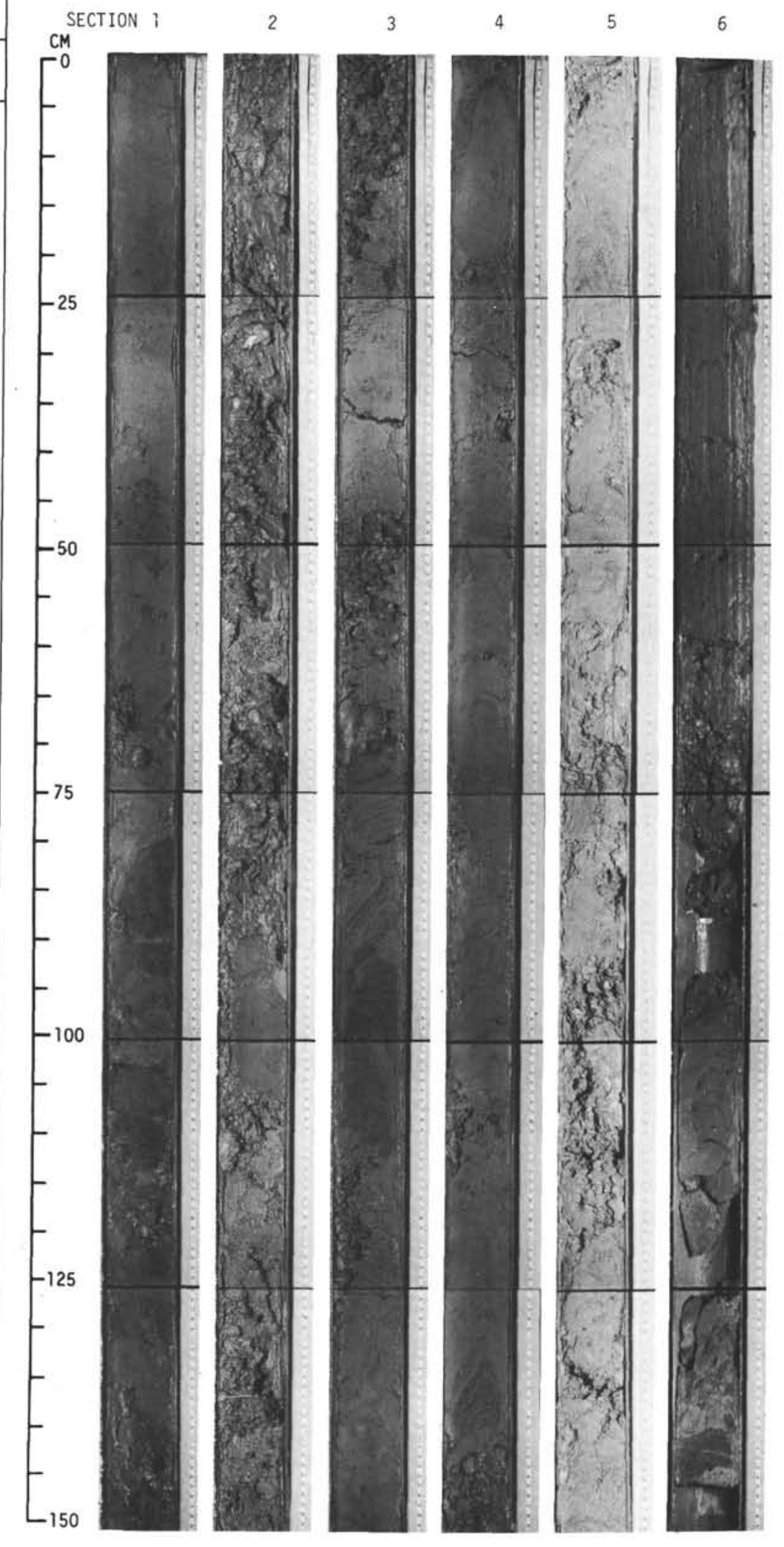




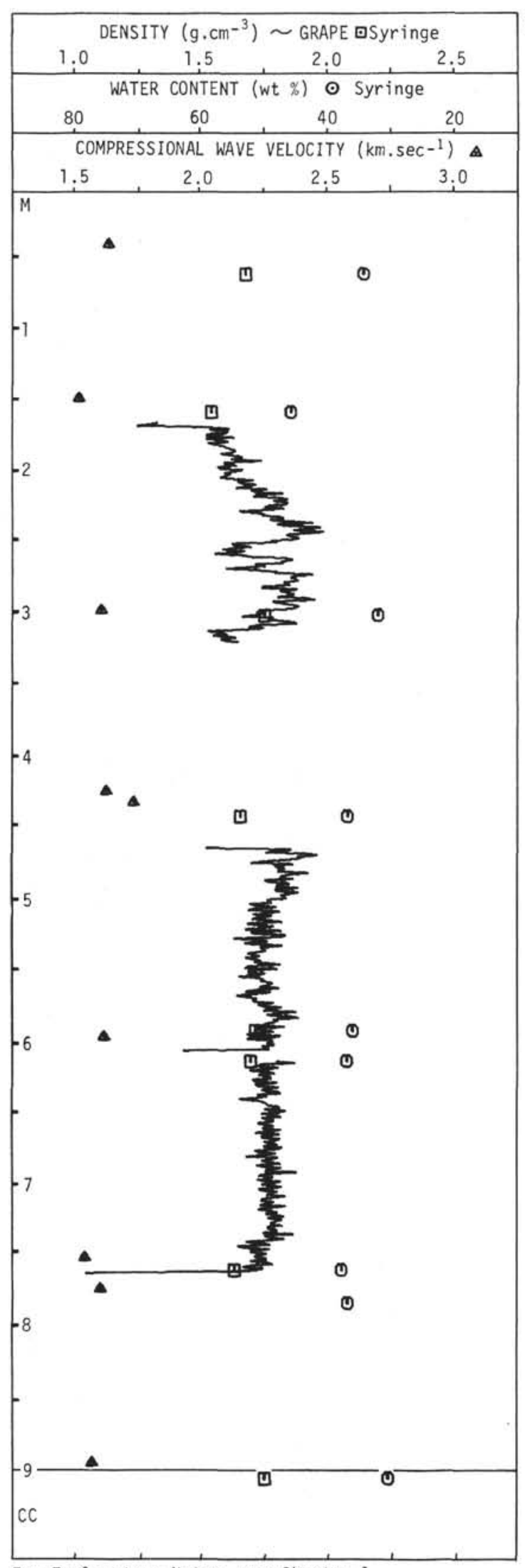

$336-8$

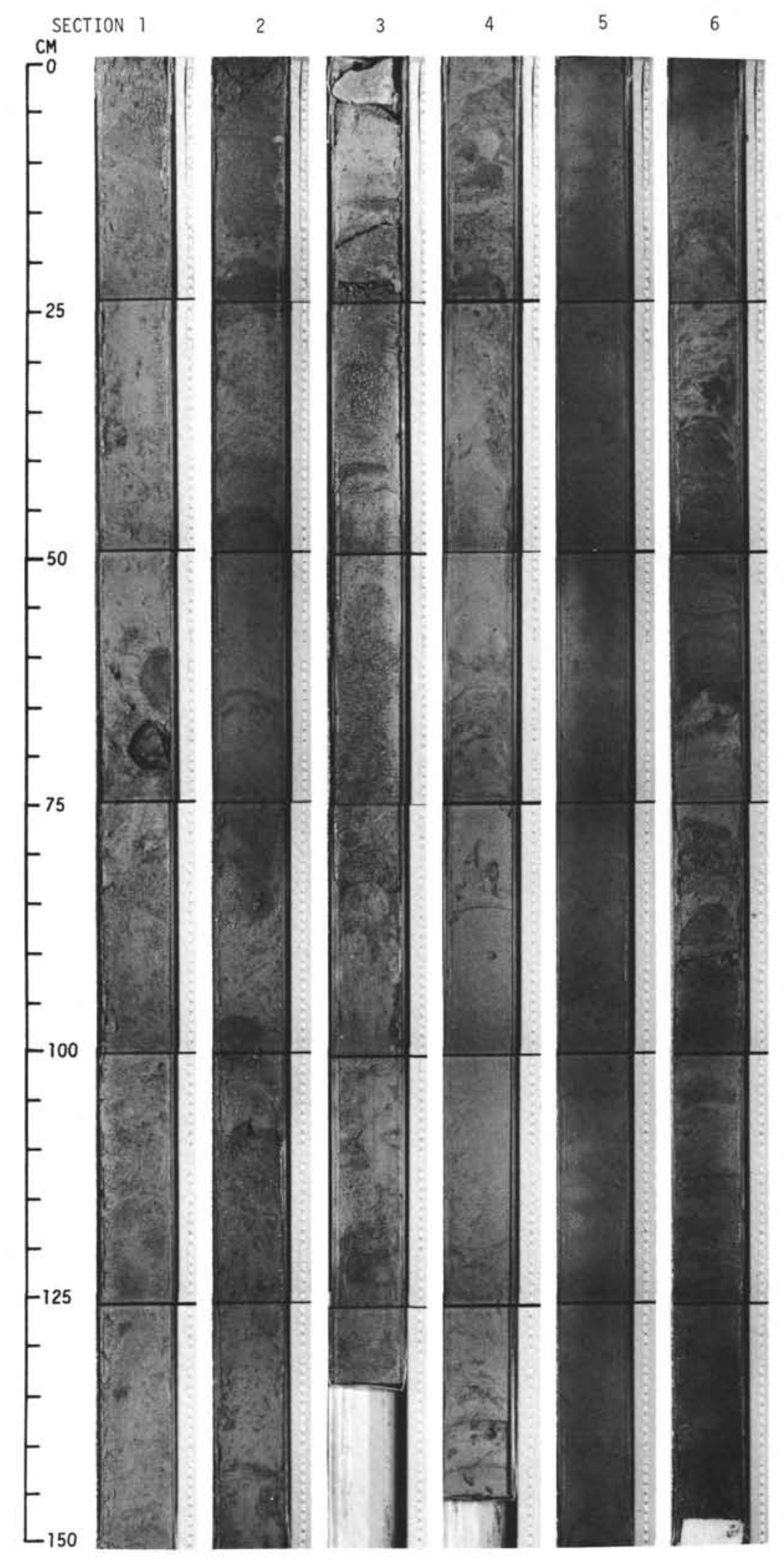




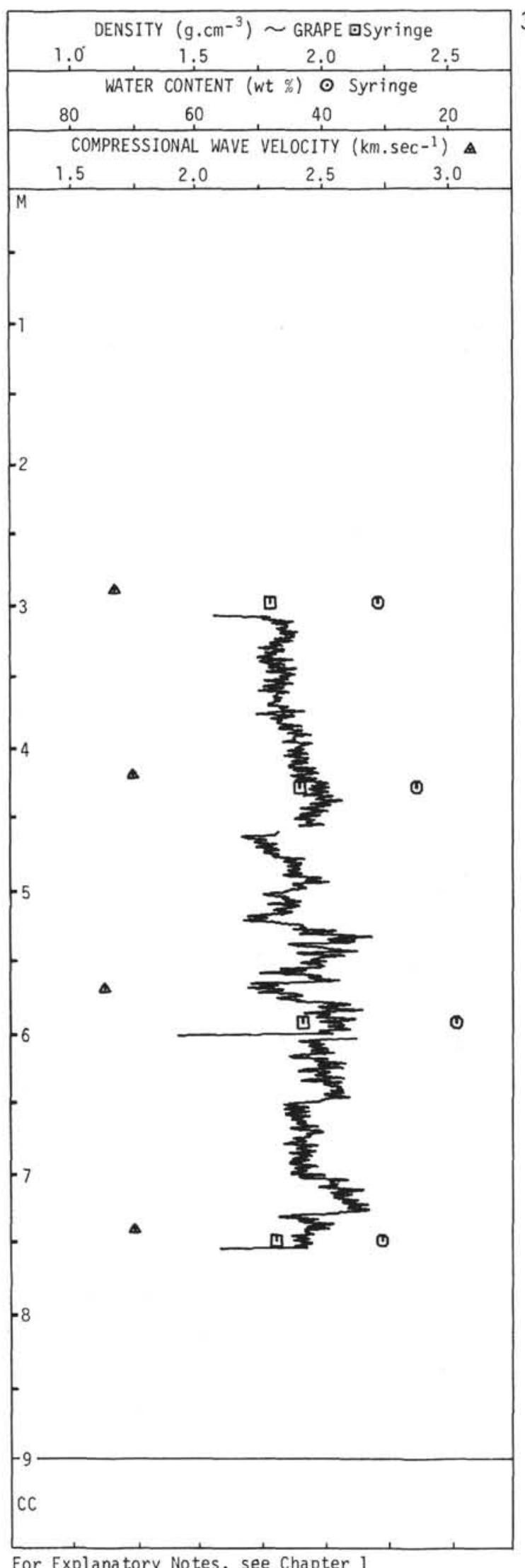

336-9

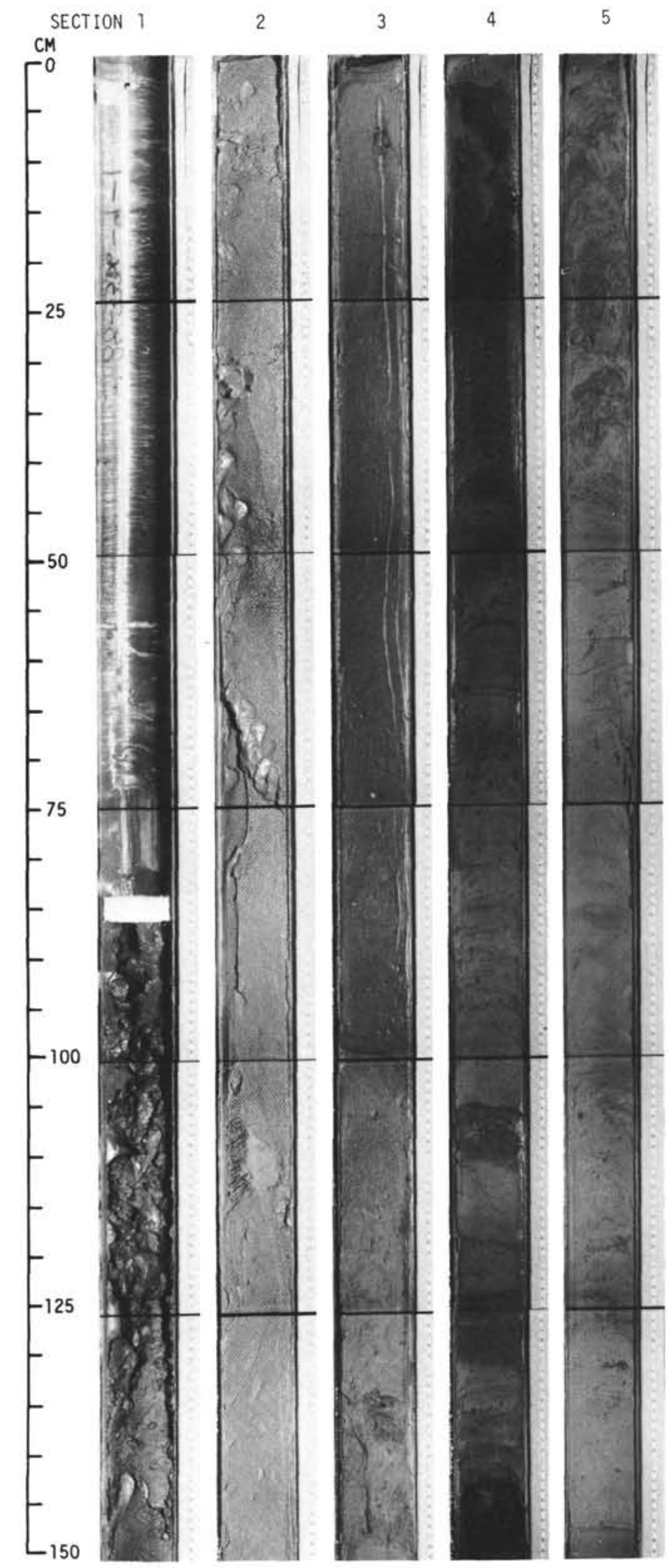




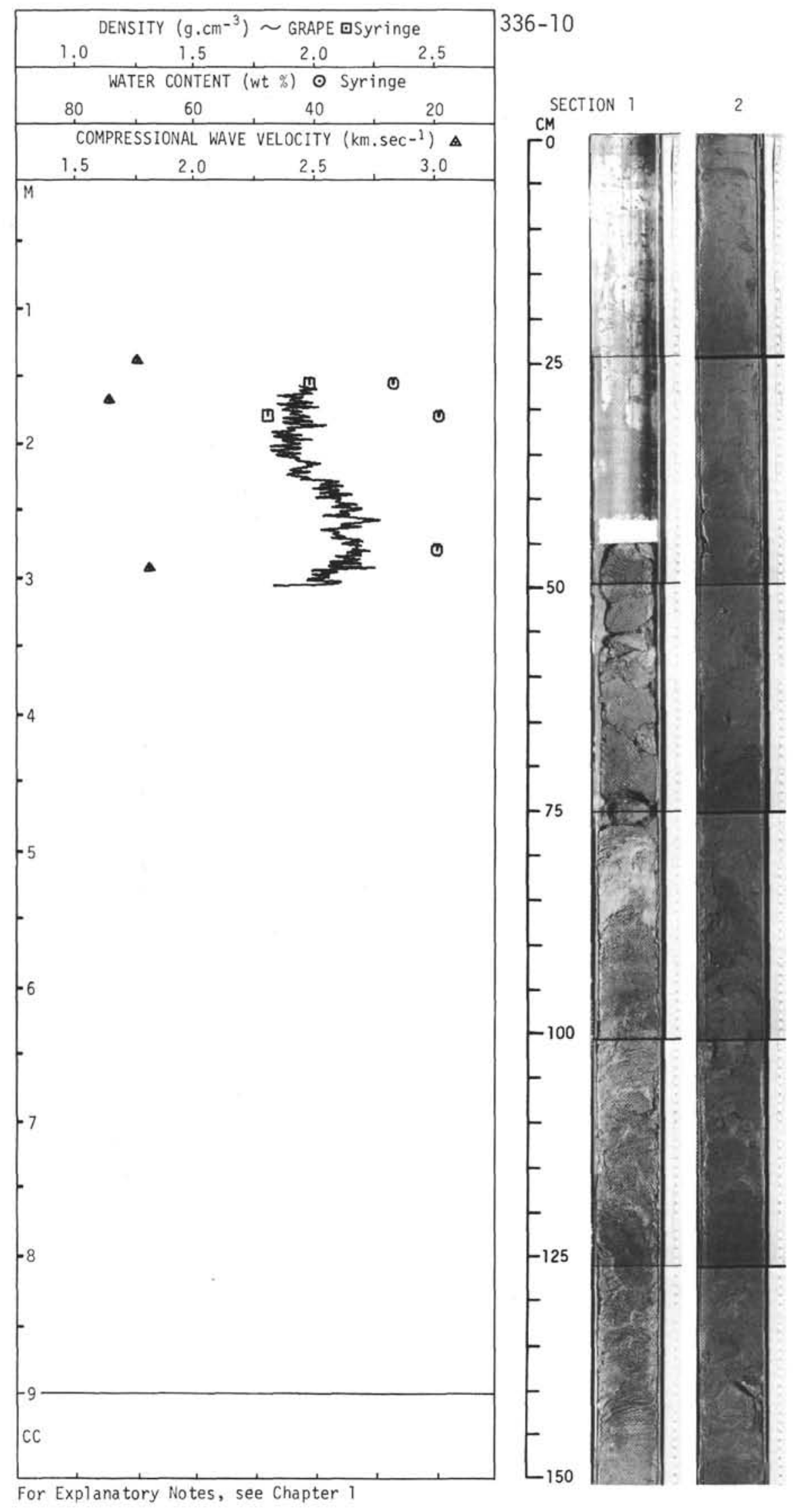




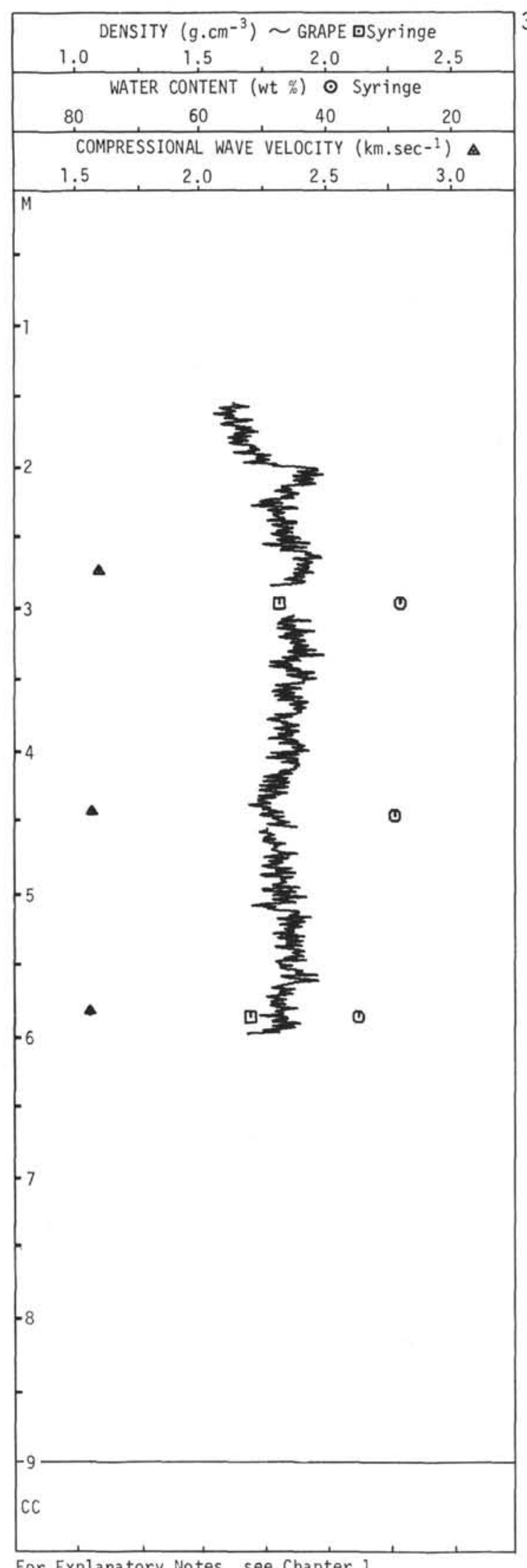

$336-11$

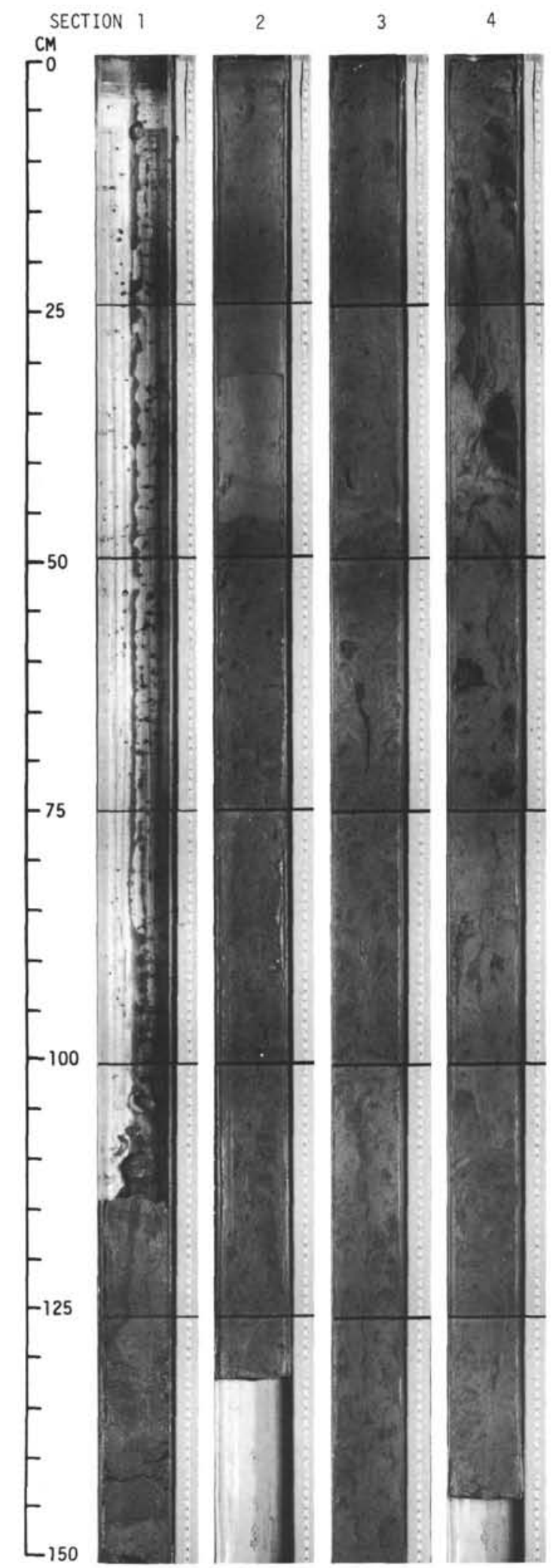




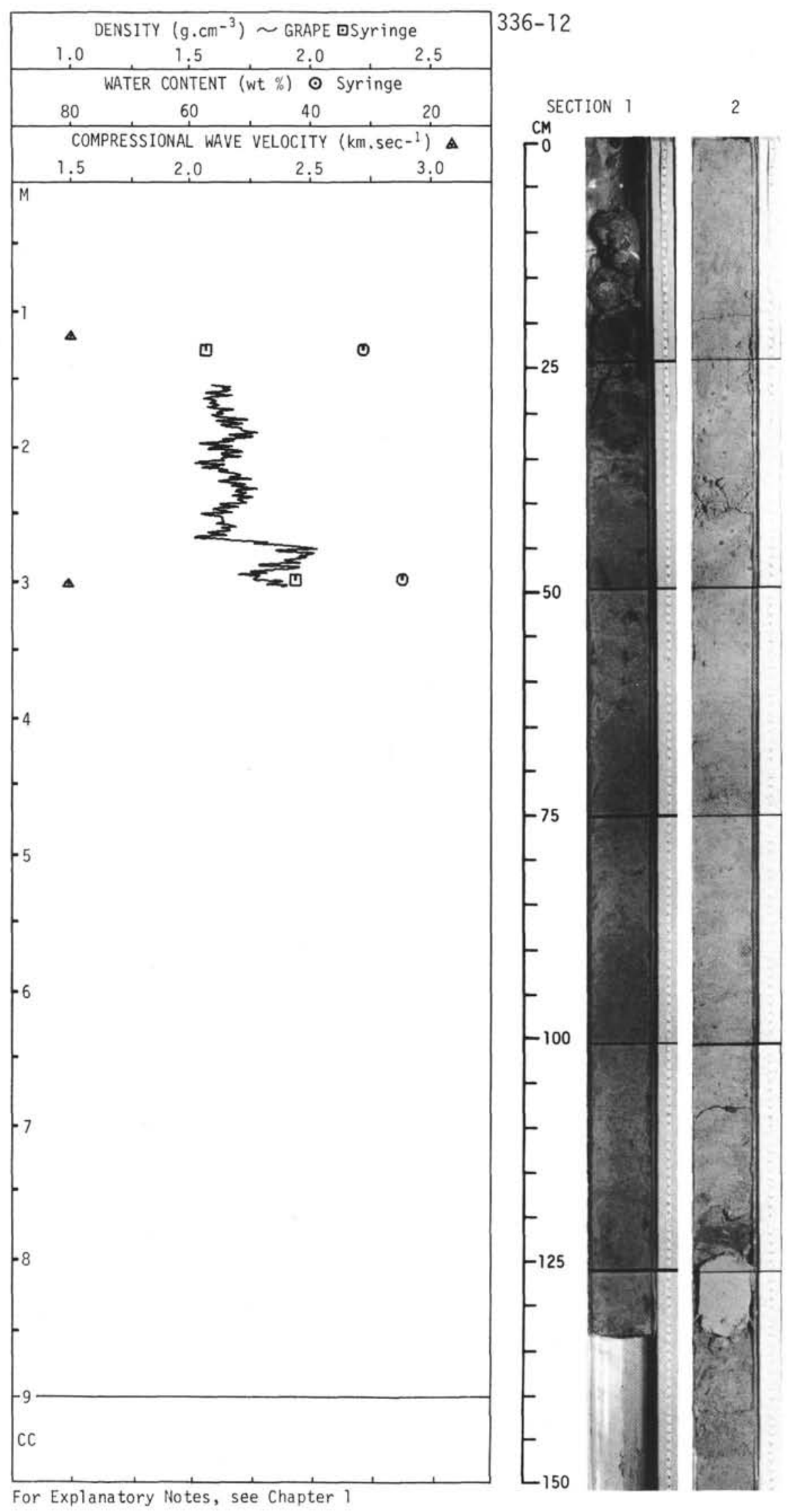




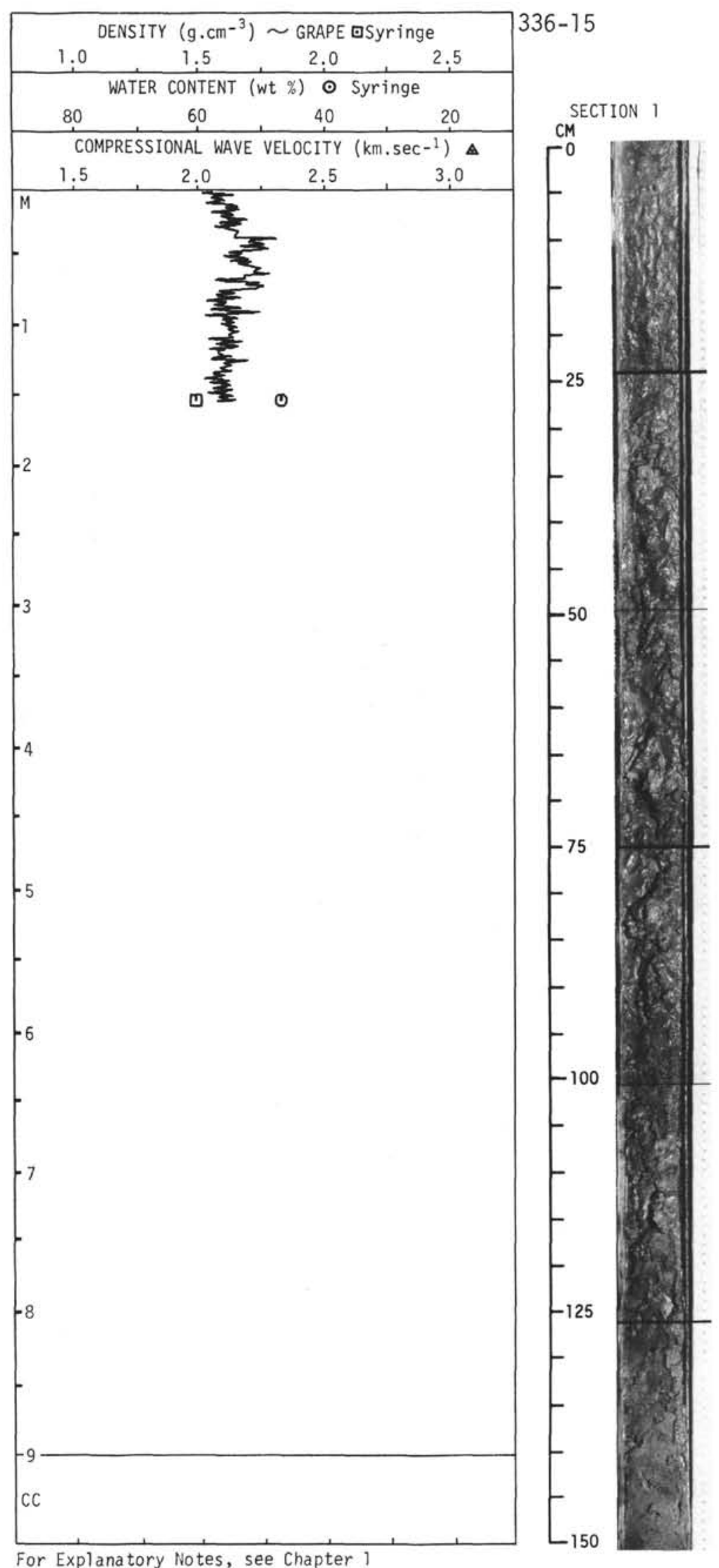




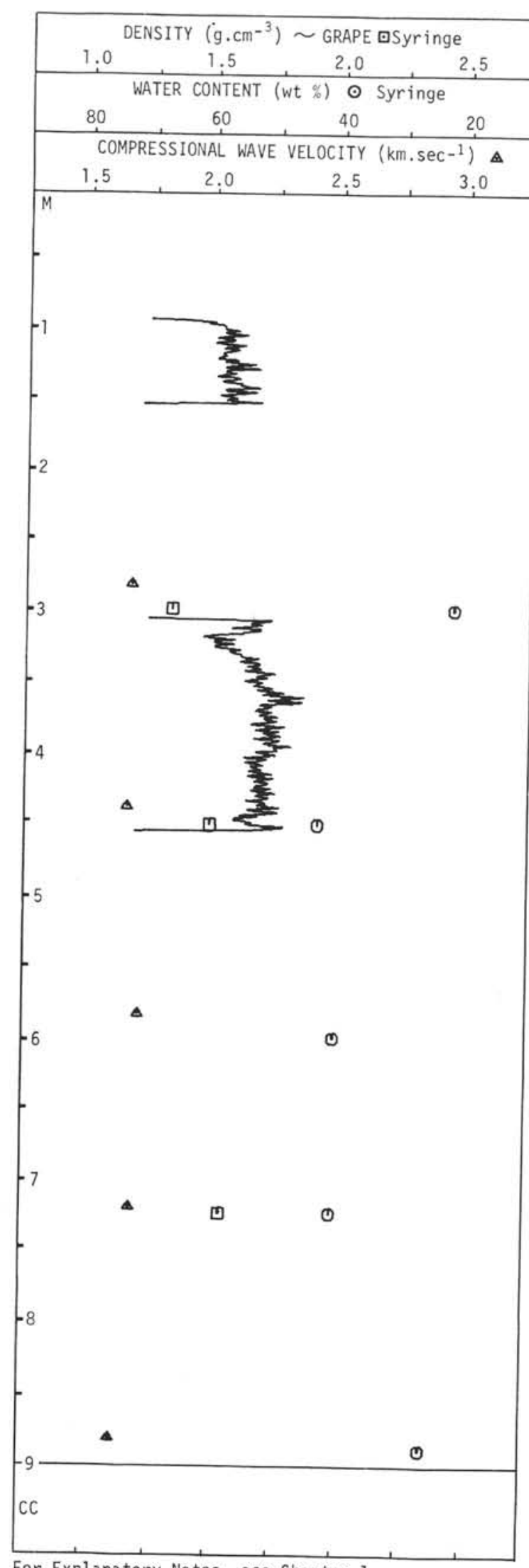

$336-16$

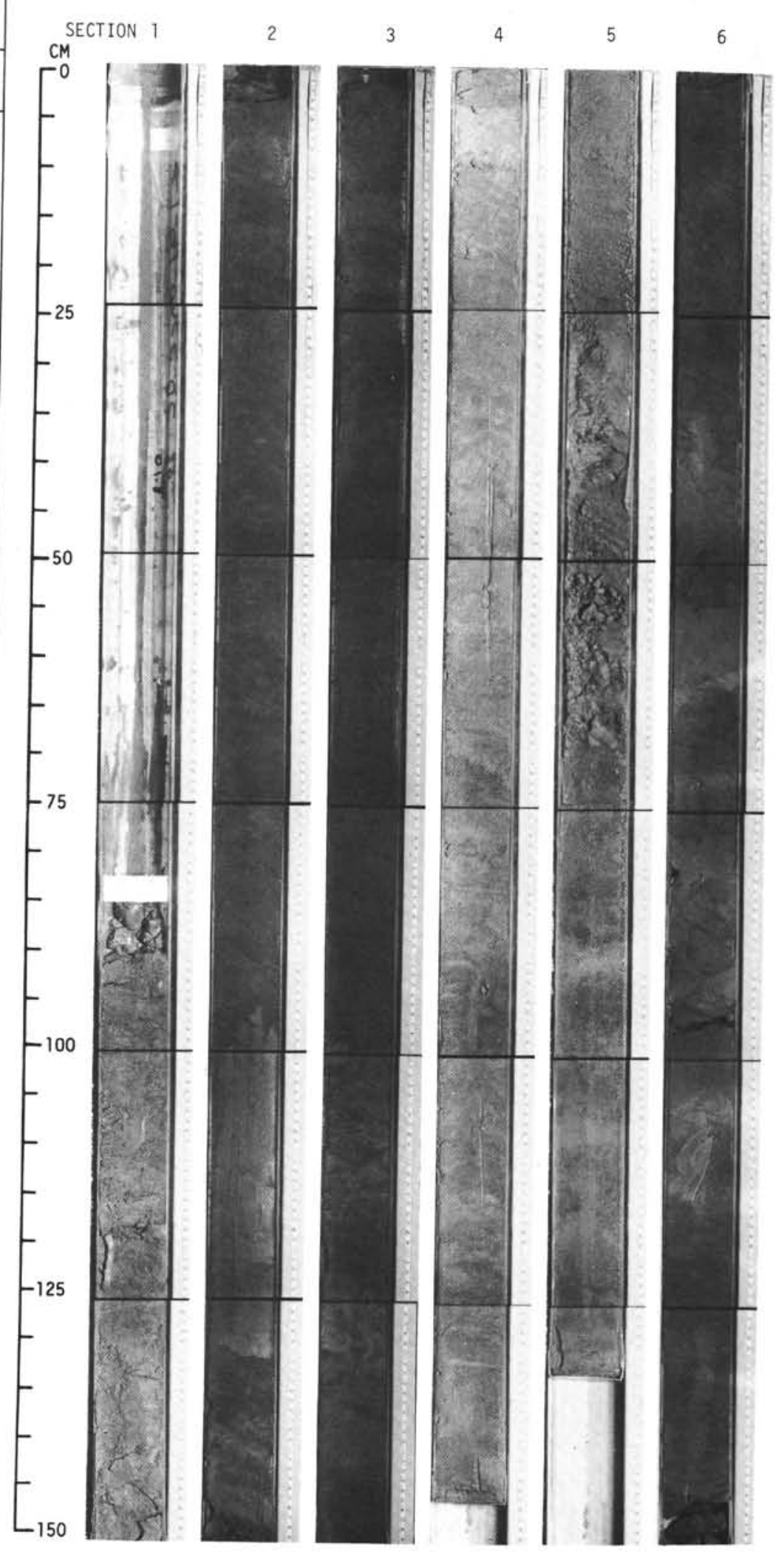




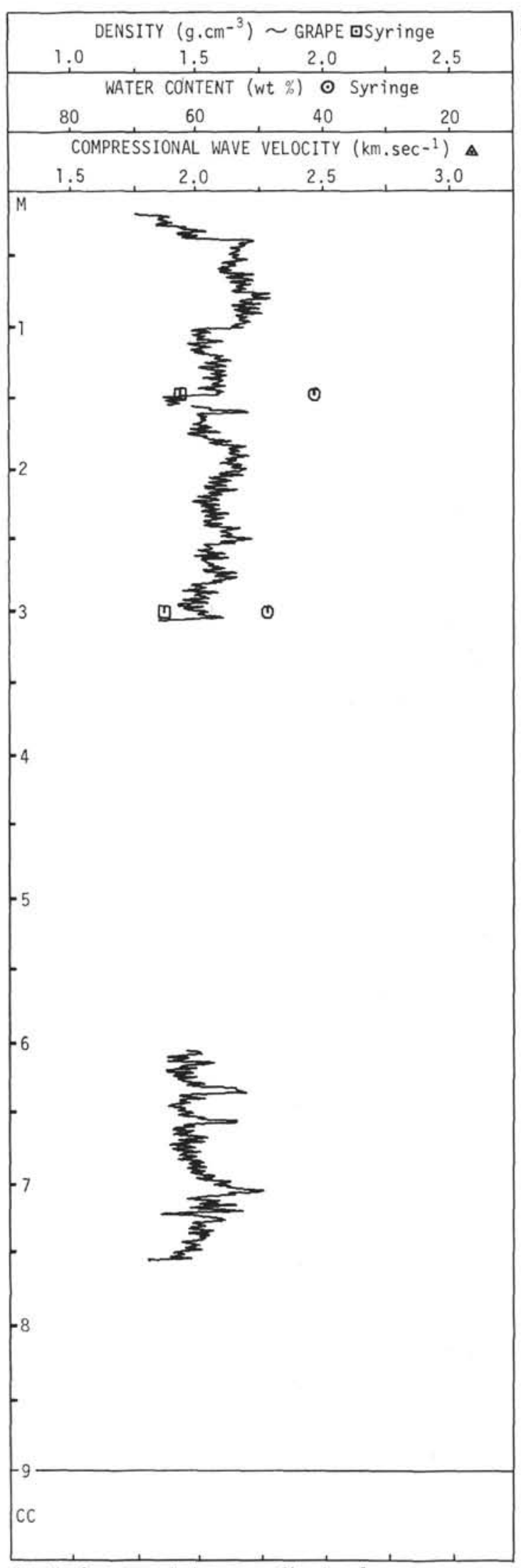

$336-18$

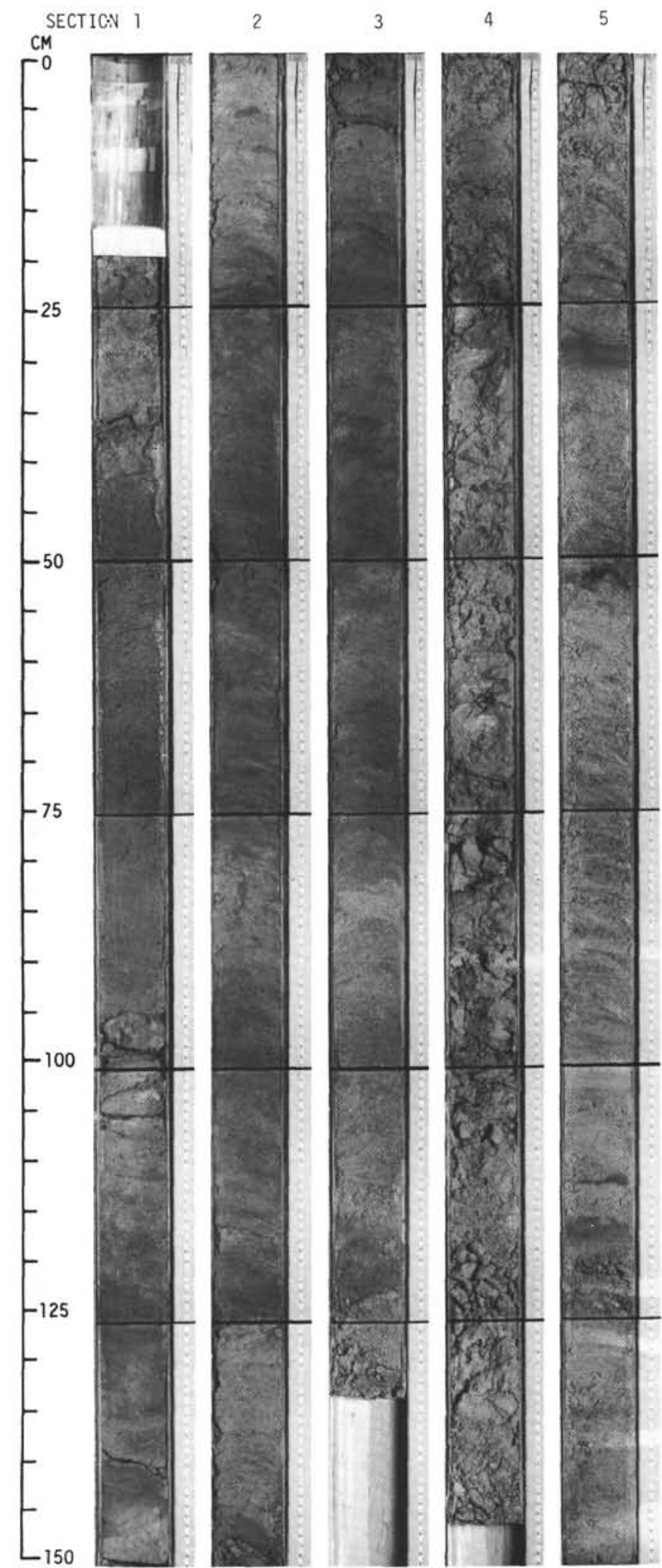

For Explanatory Notes, see Chapter 1 


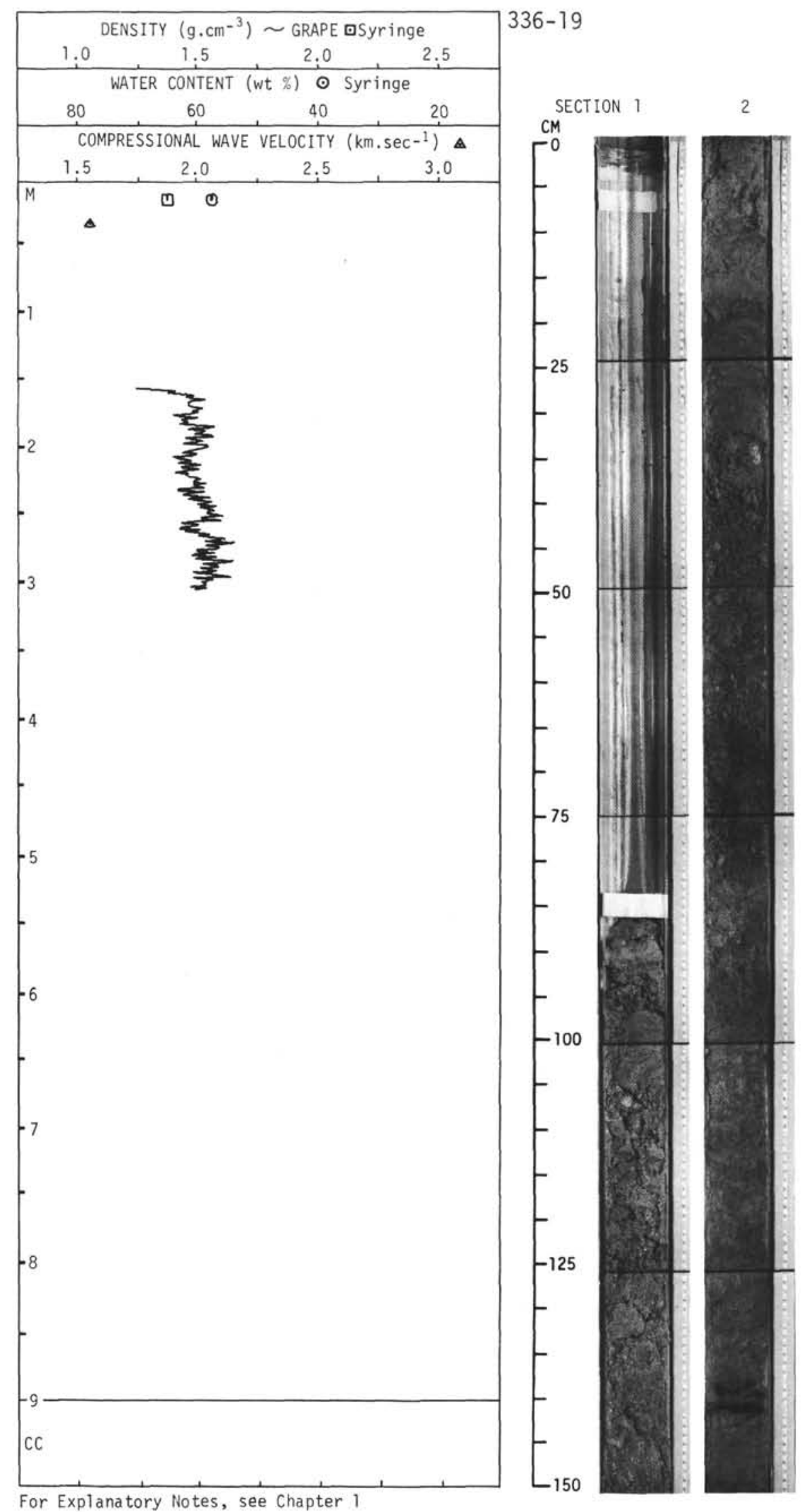




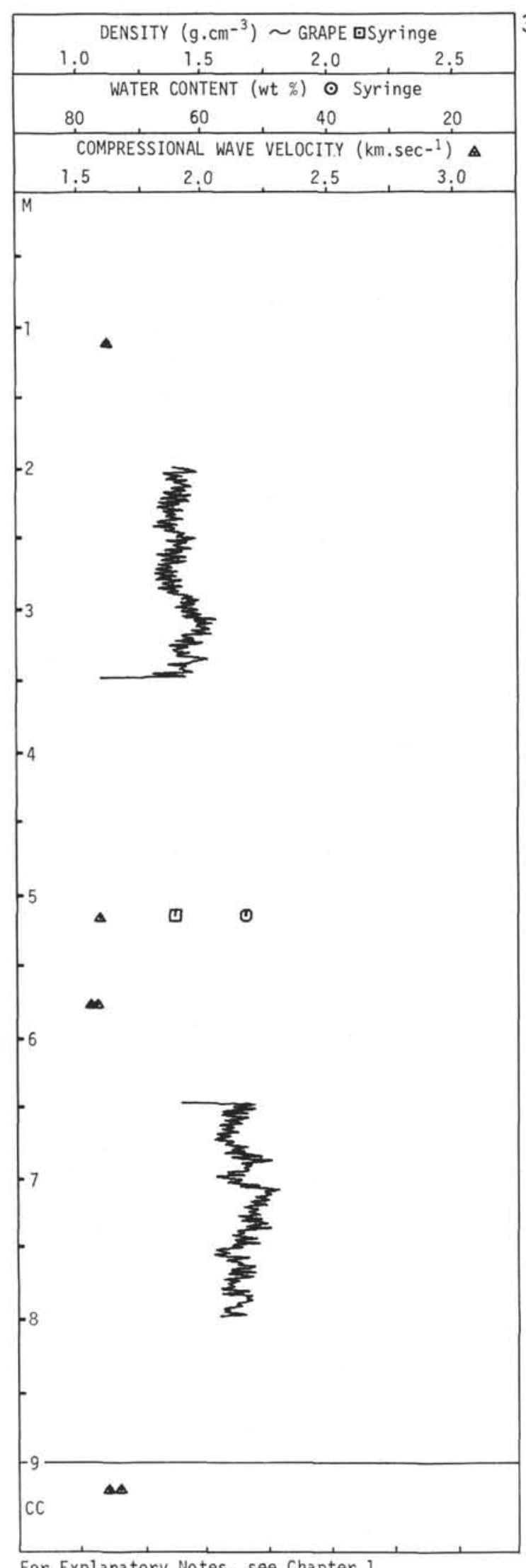

$336-20$

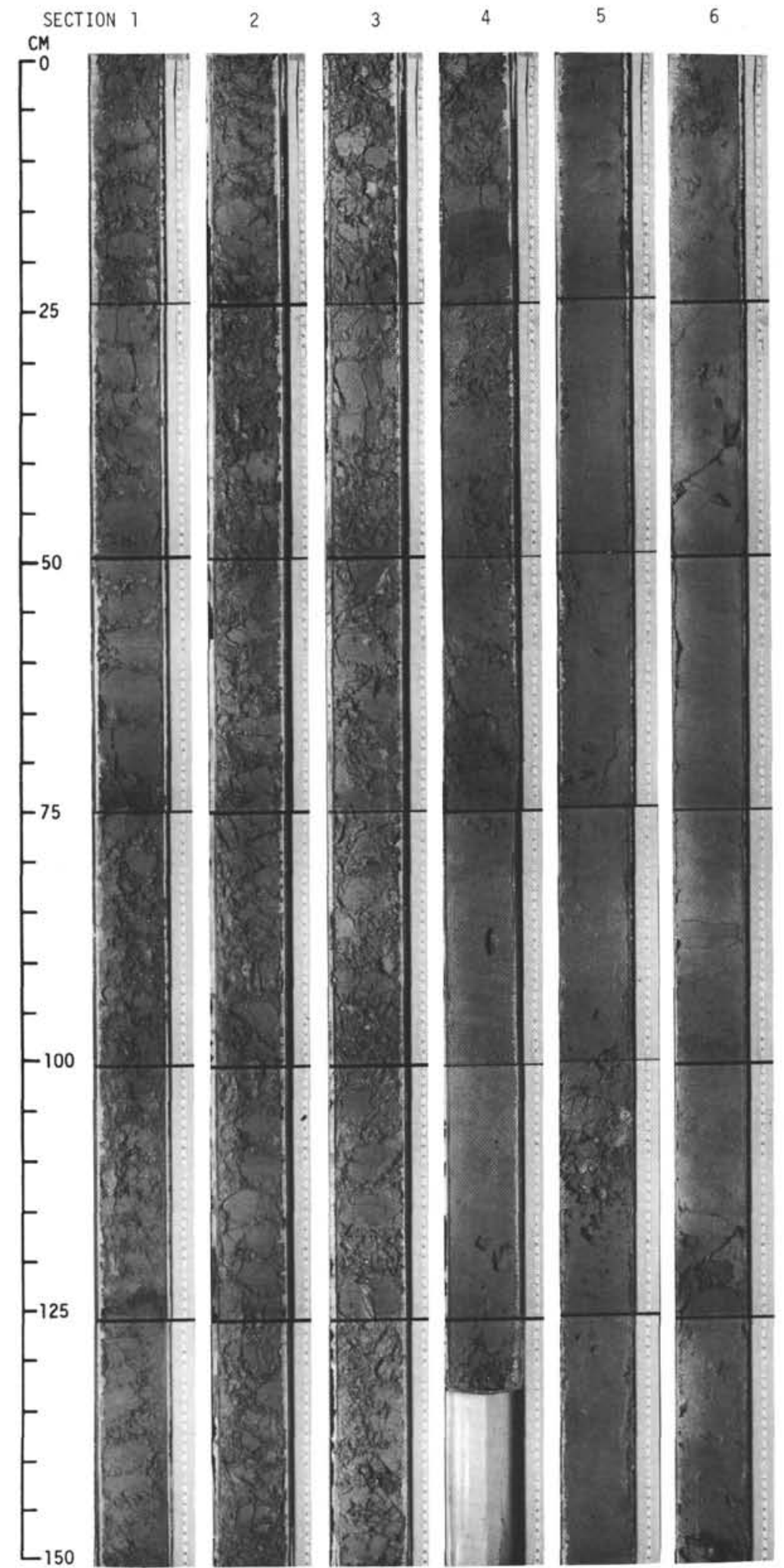




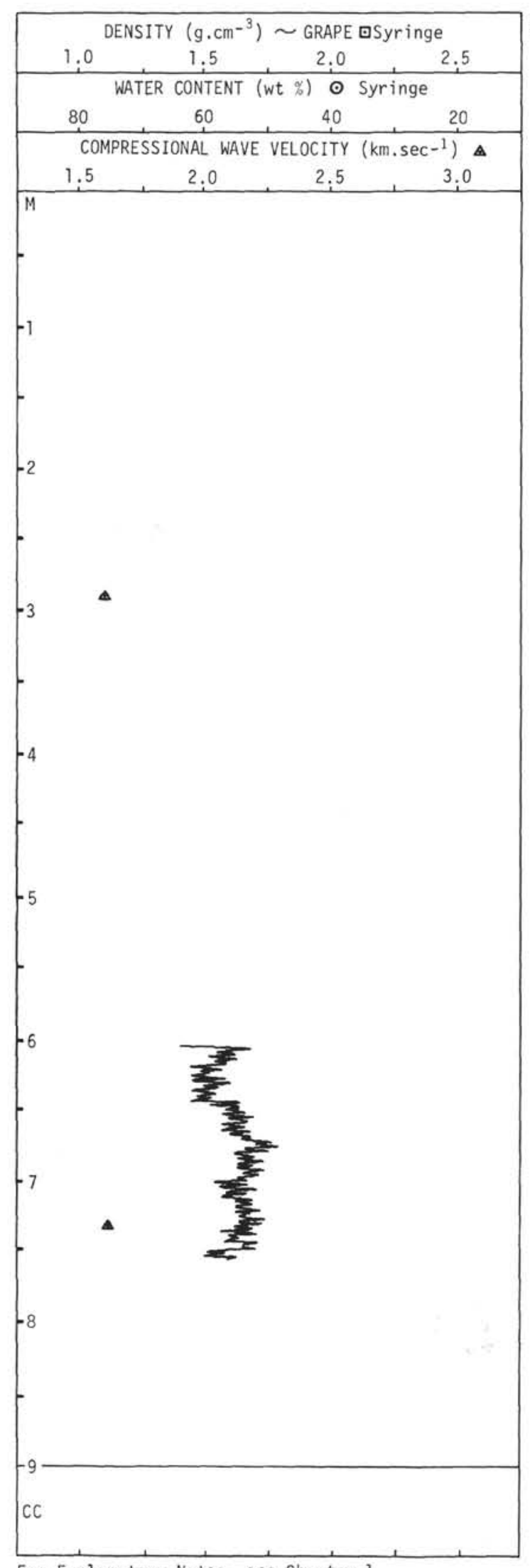

$336-21$

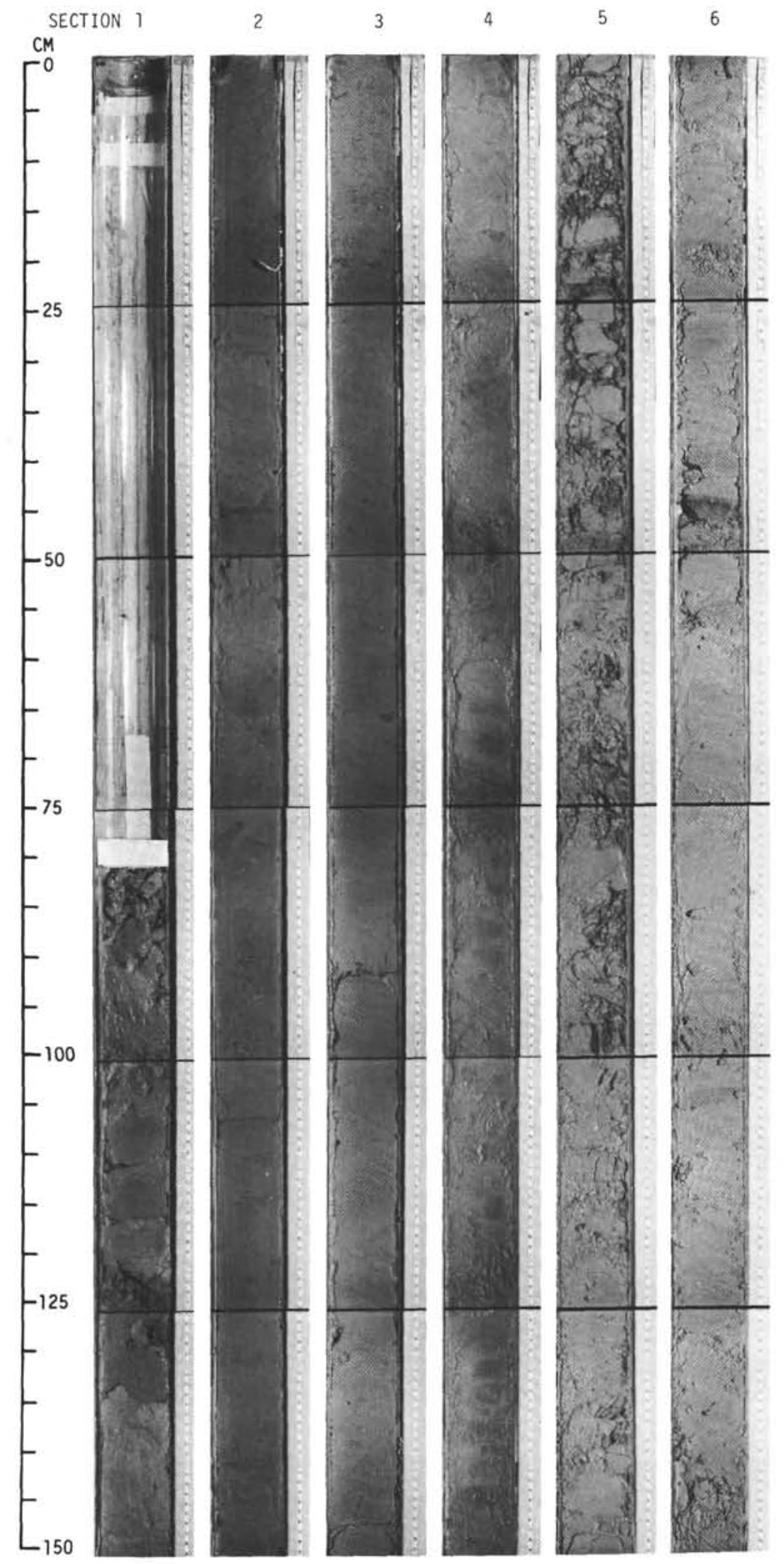




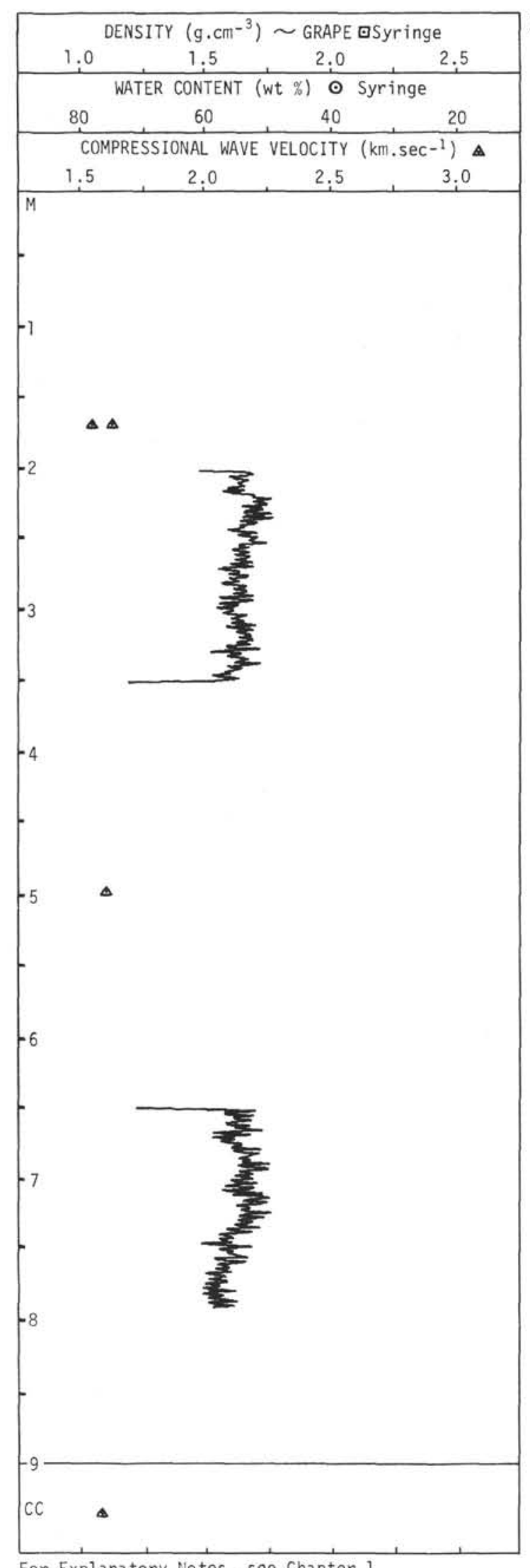

$336-22$

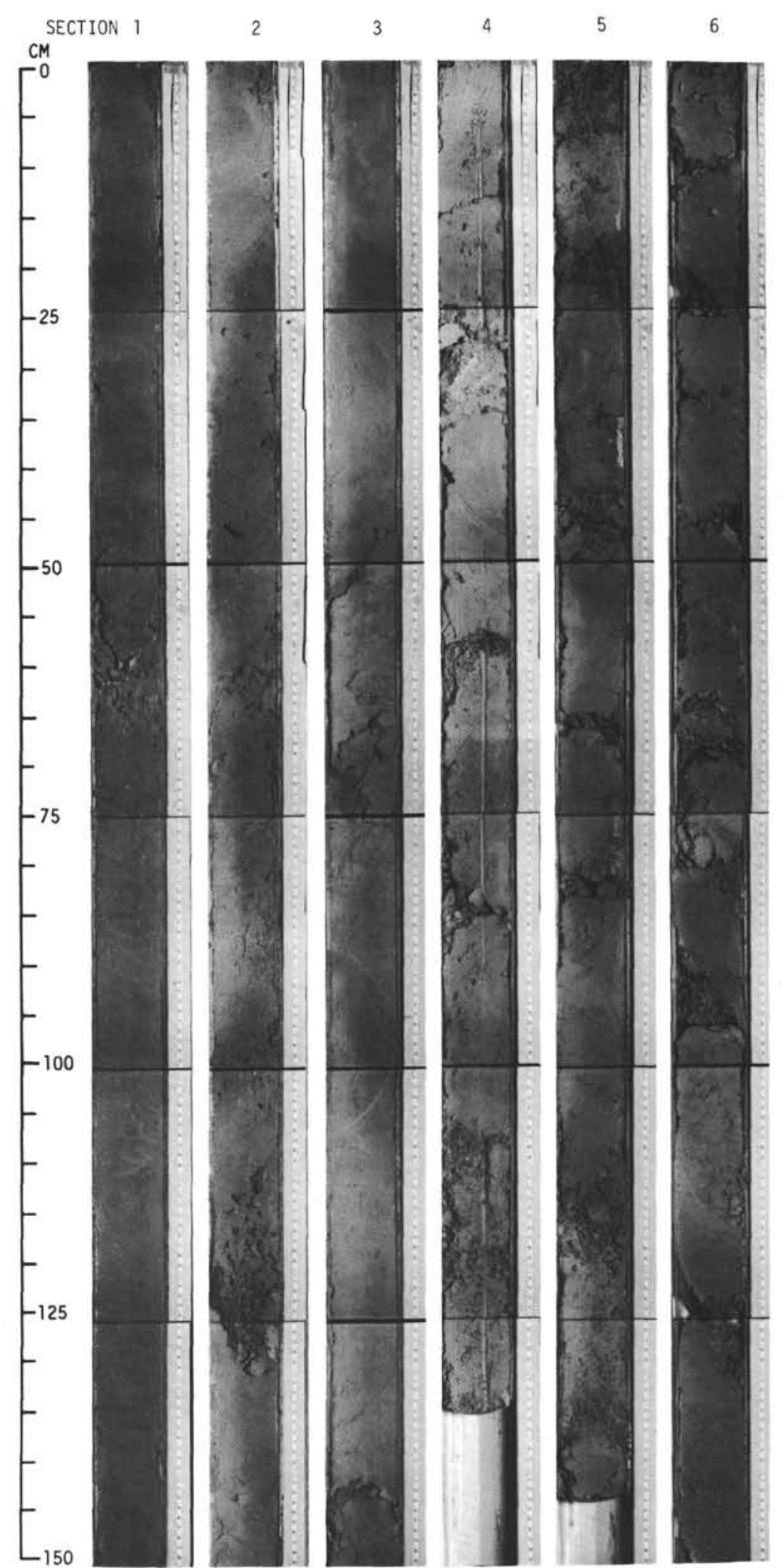




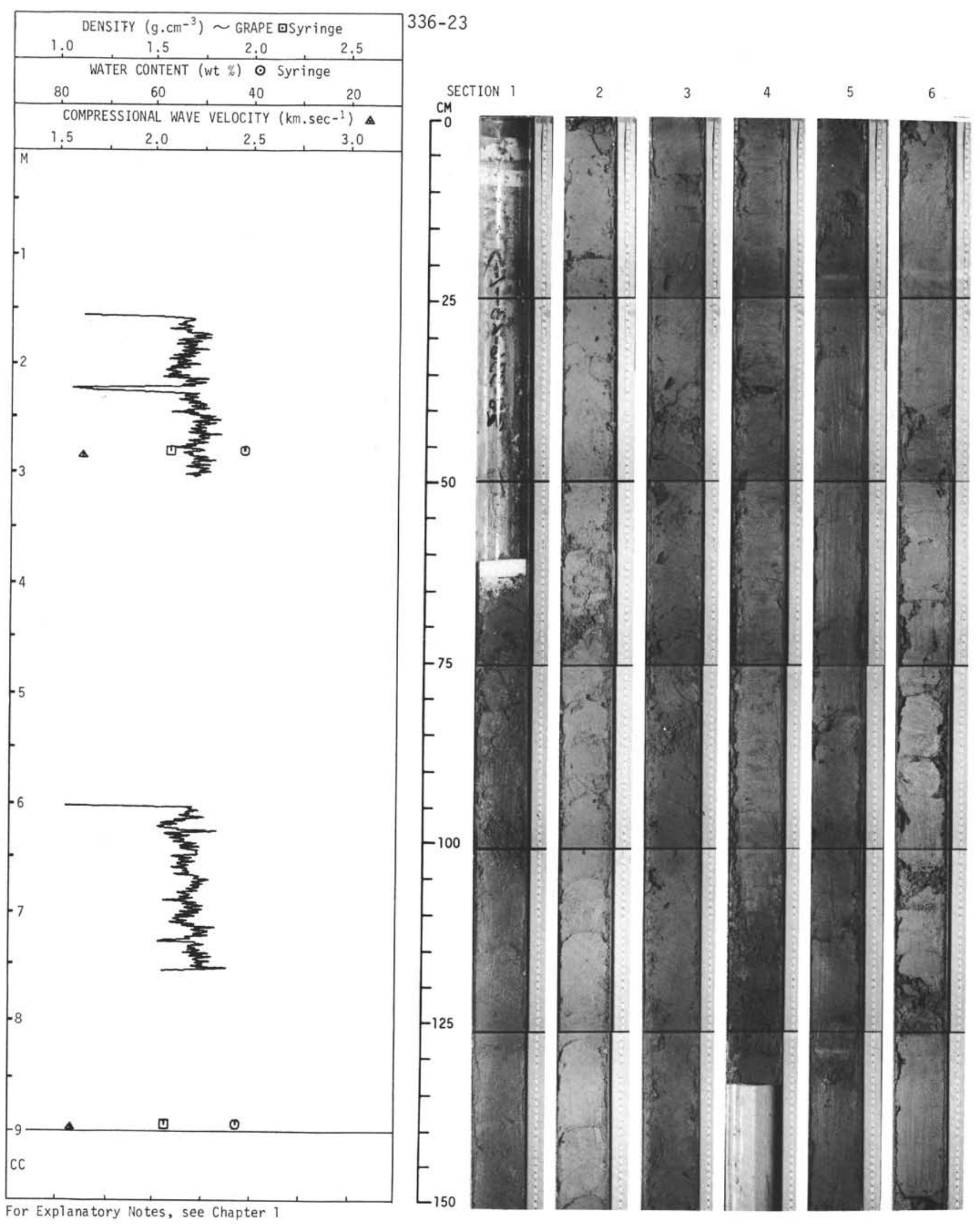




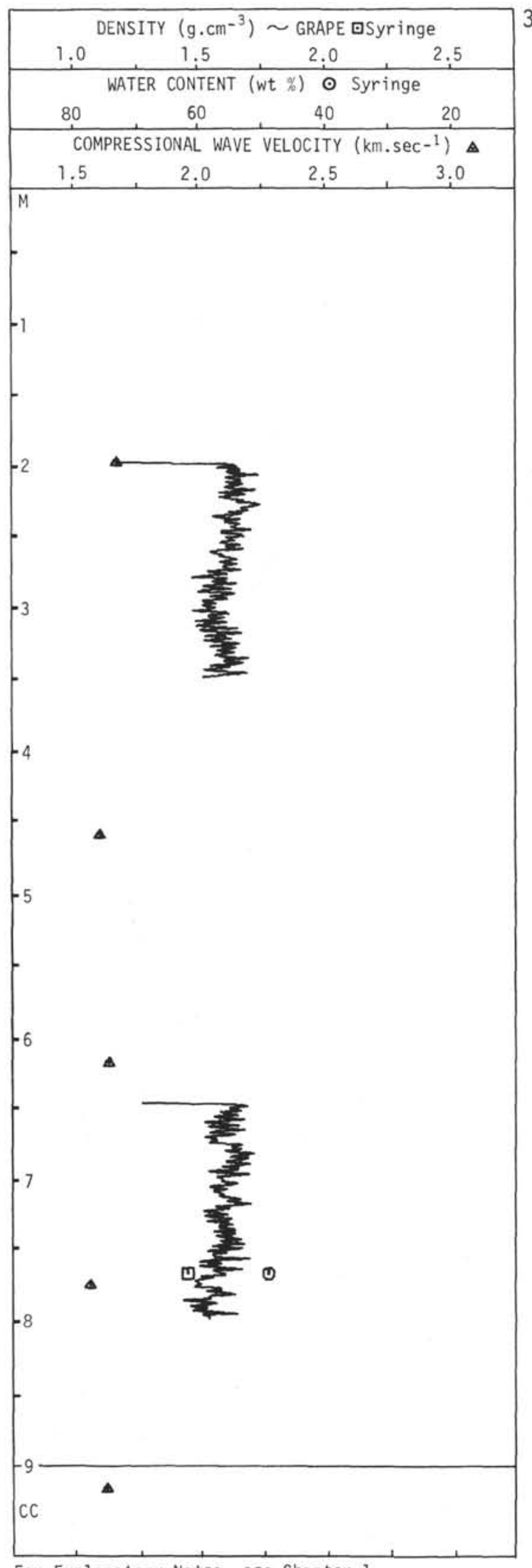

$336-24$

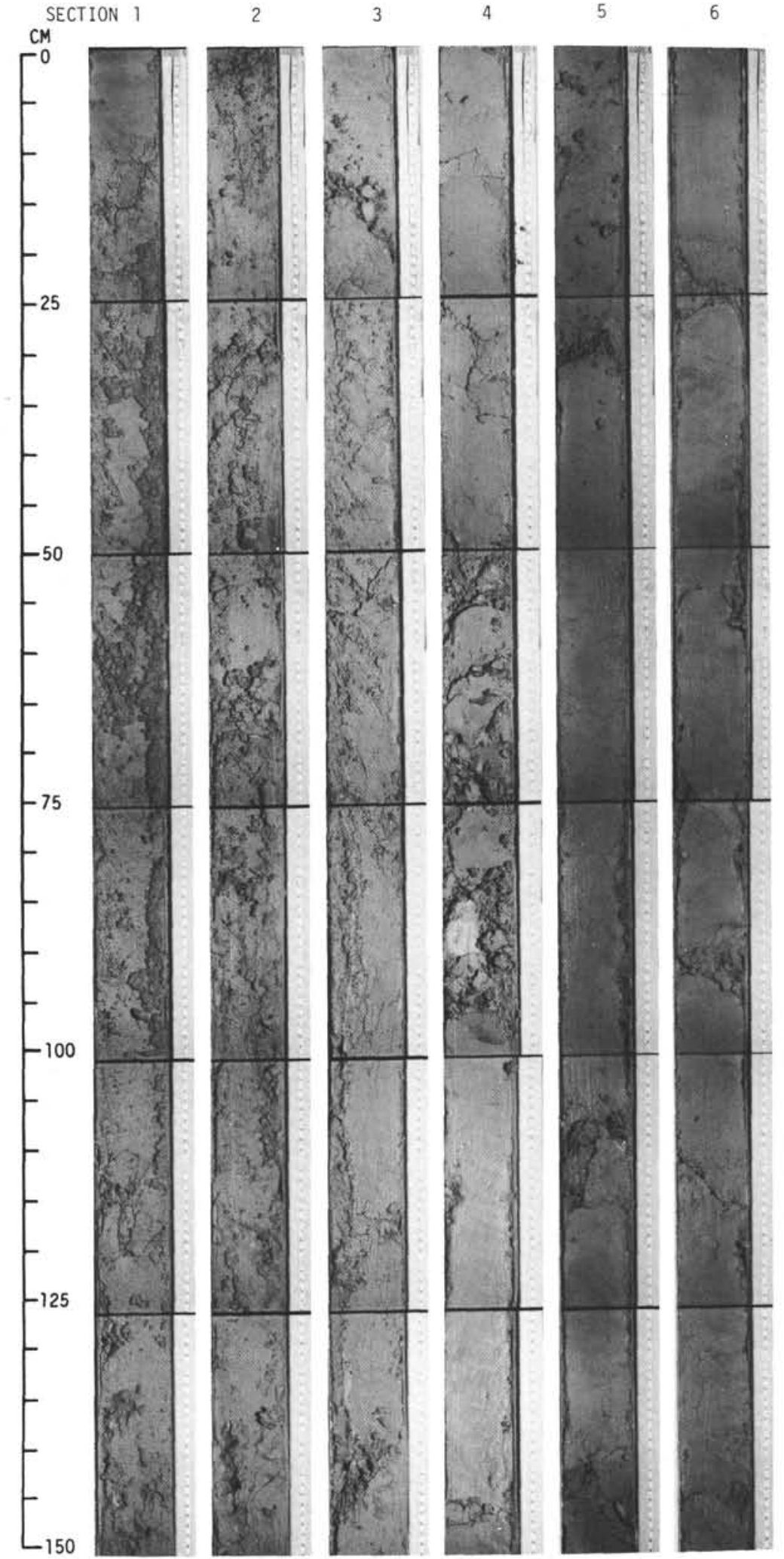




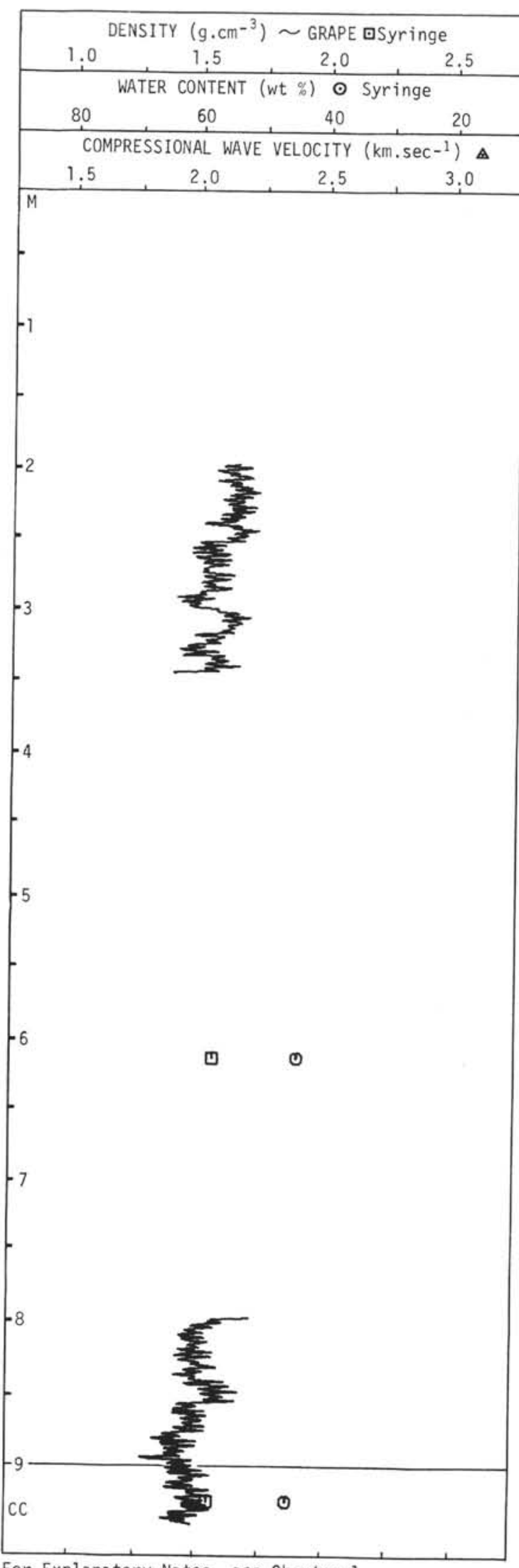

$336-25$

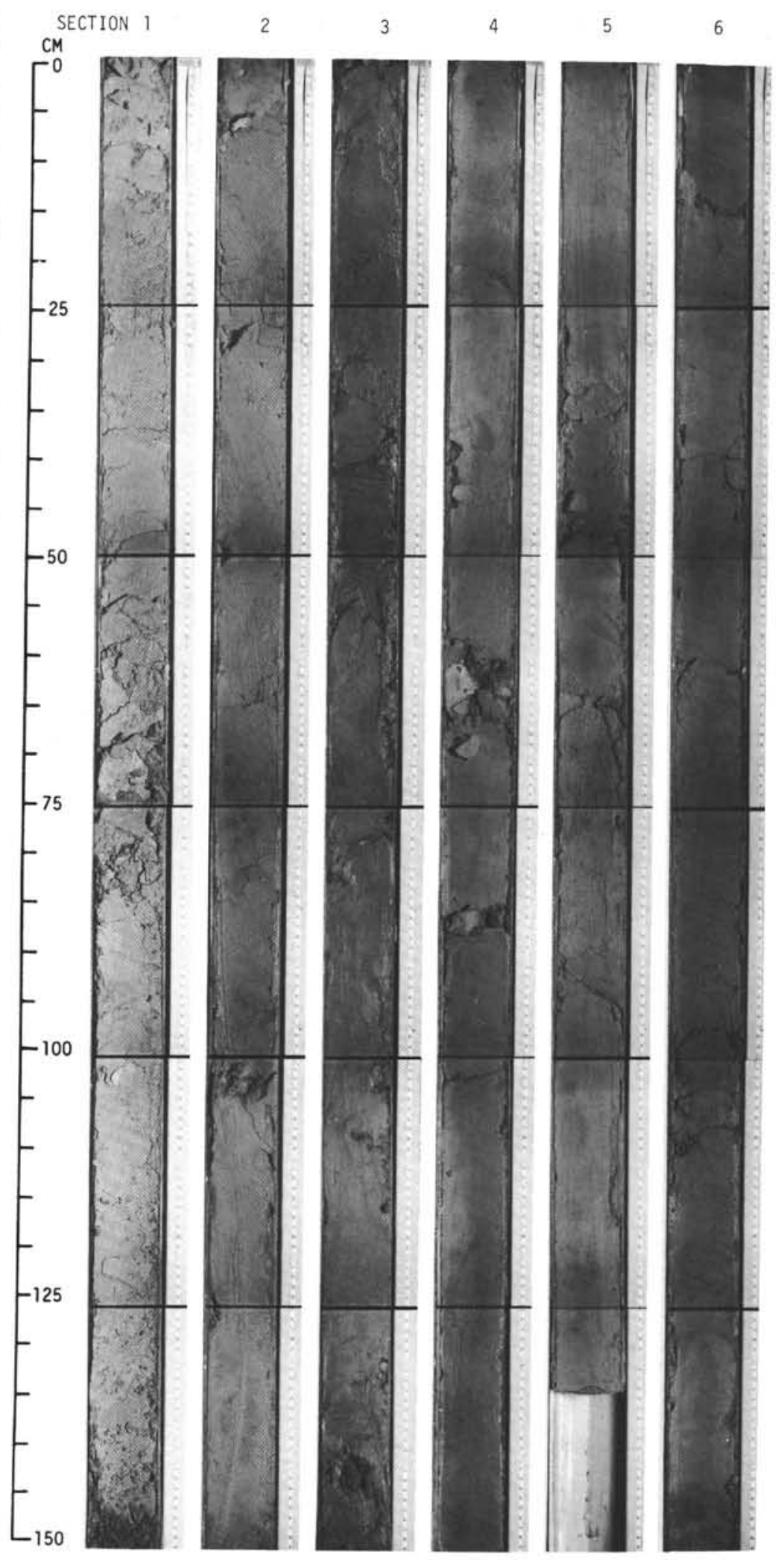




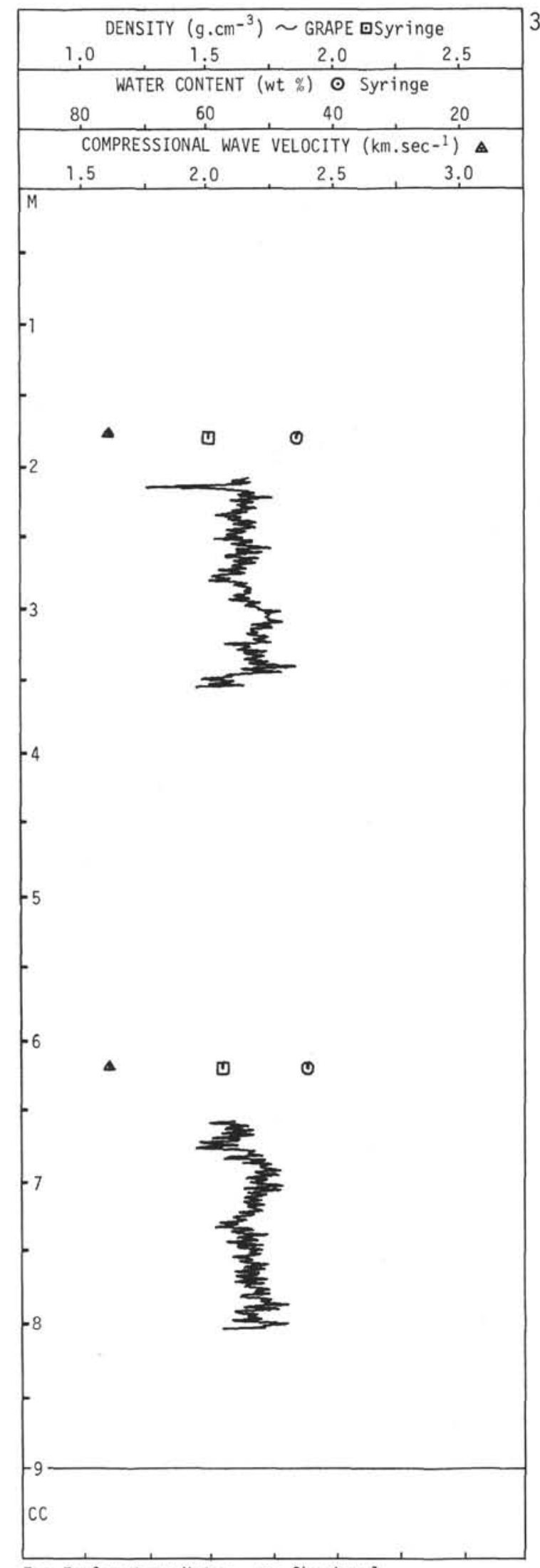

$336-26$

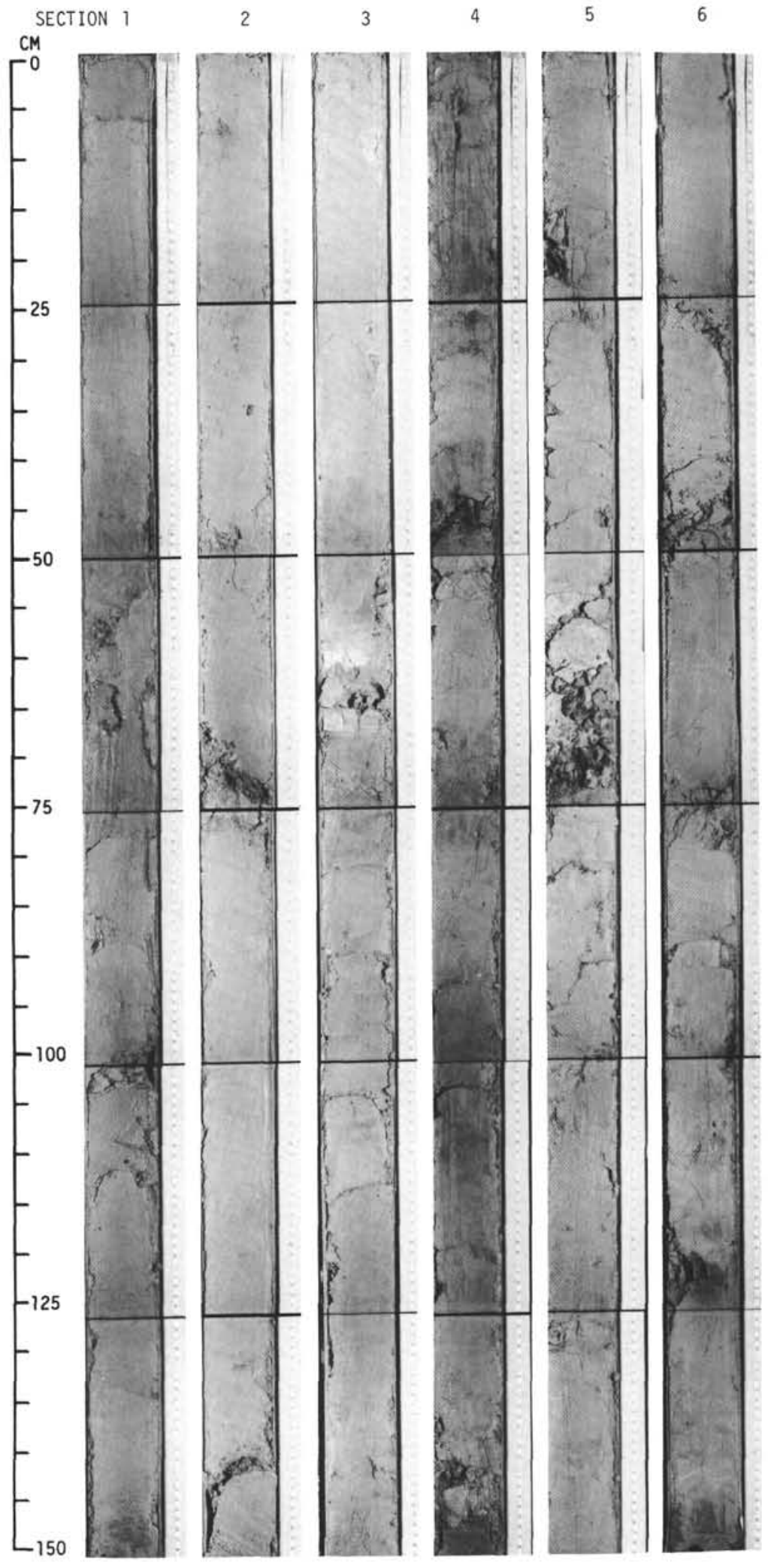




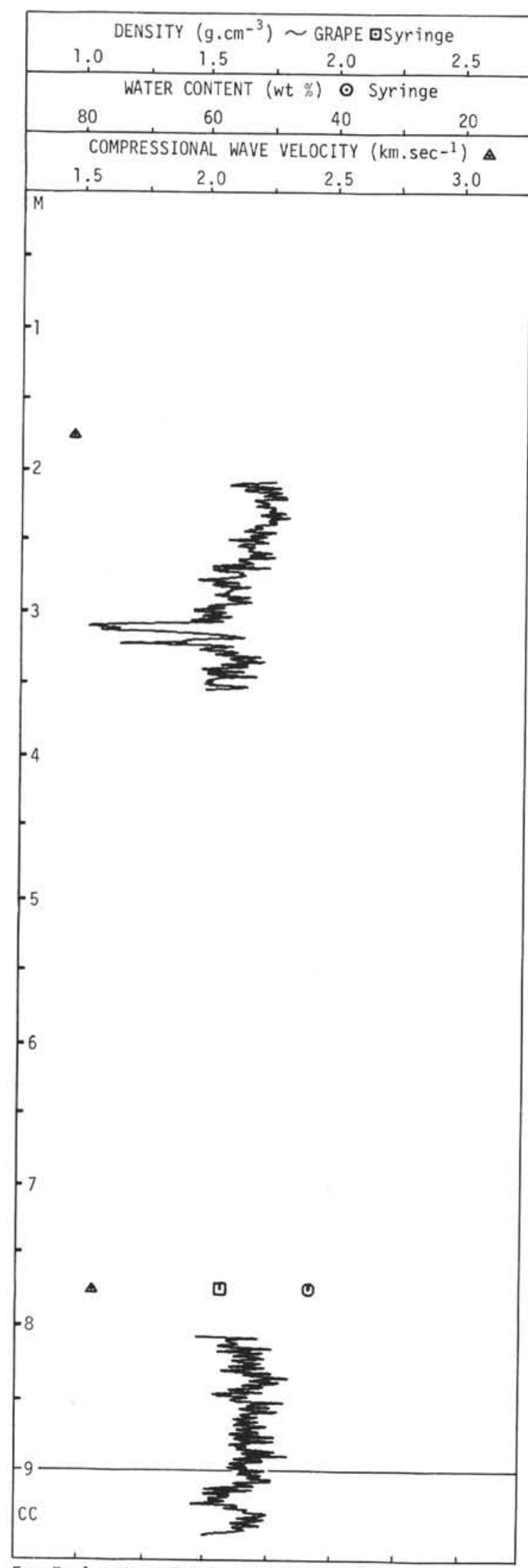

$336-27$

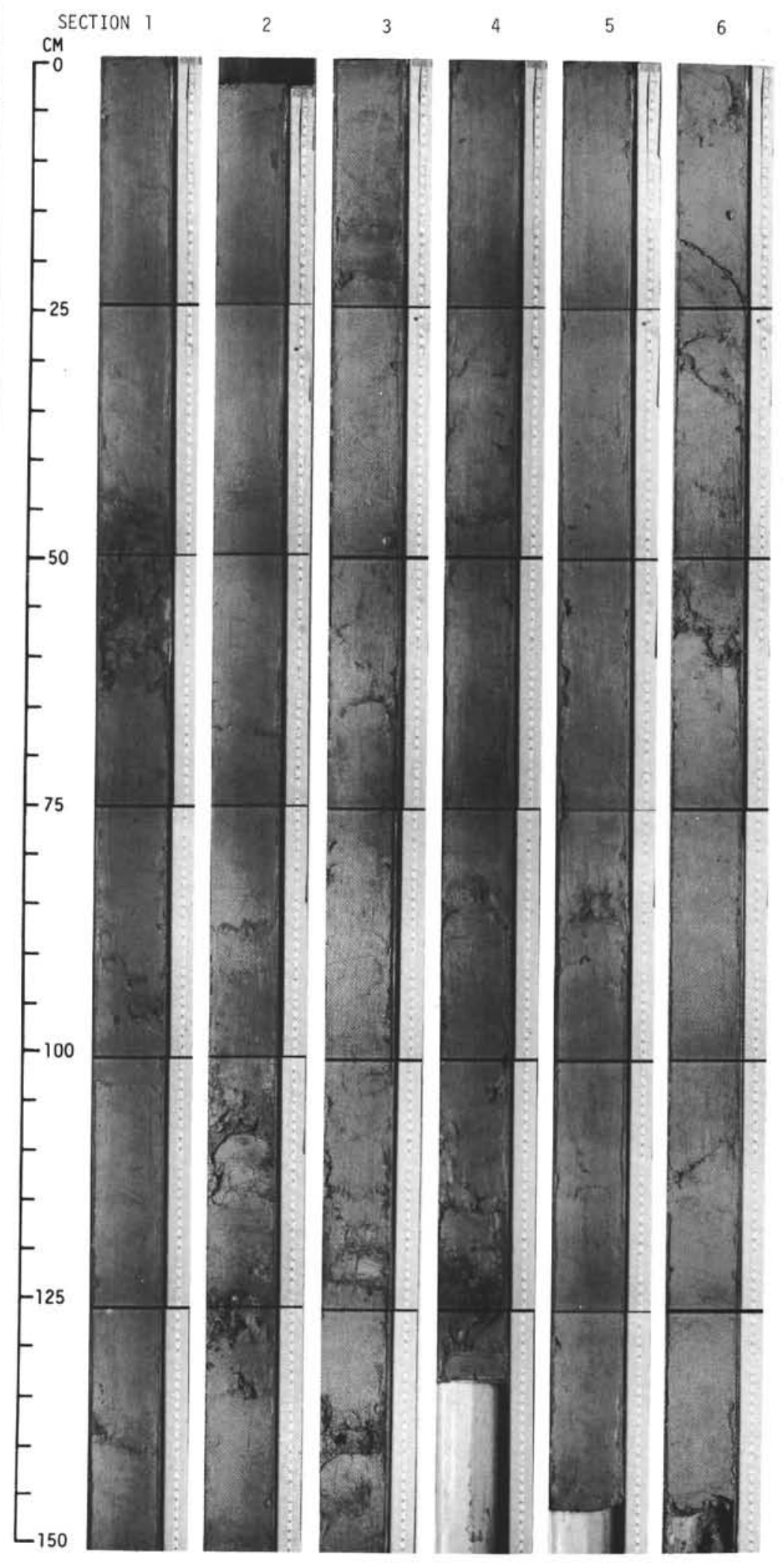




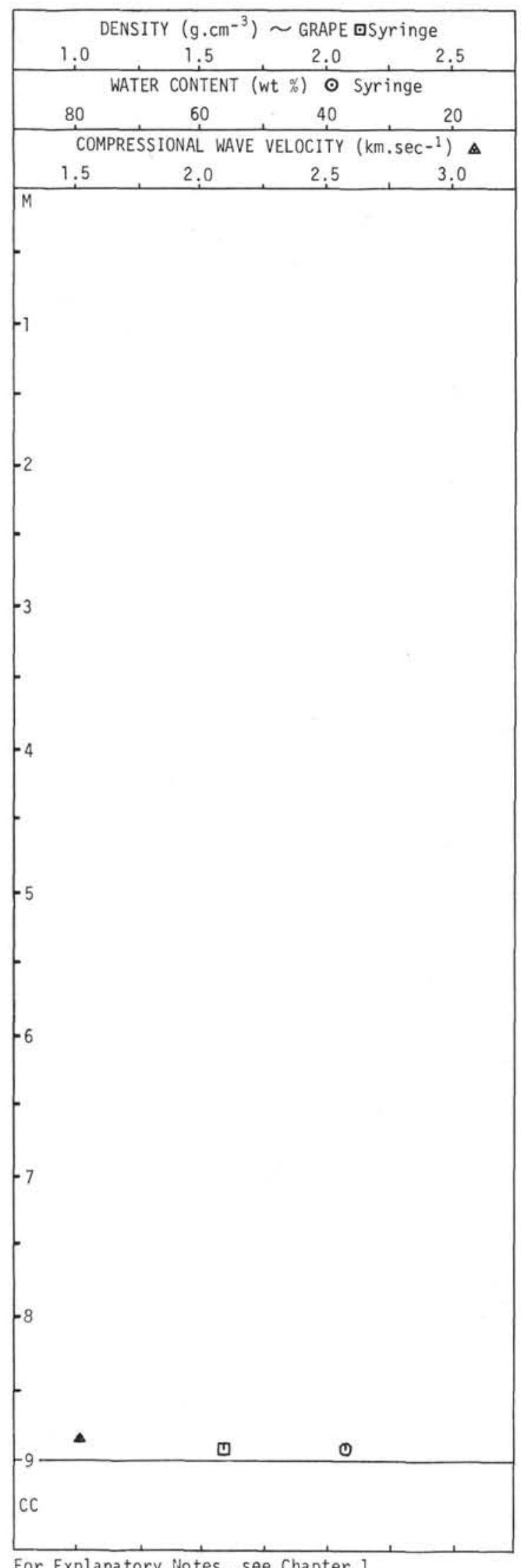

$336-28$

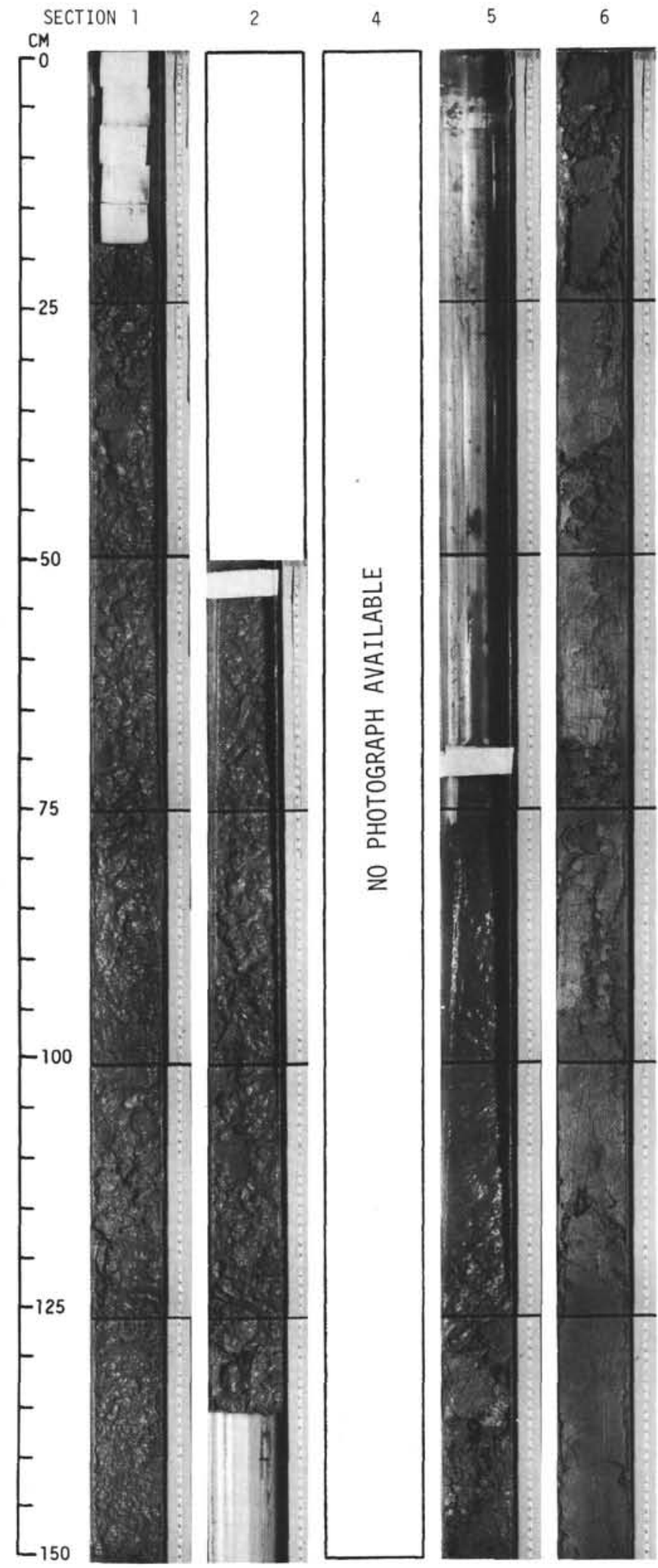




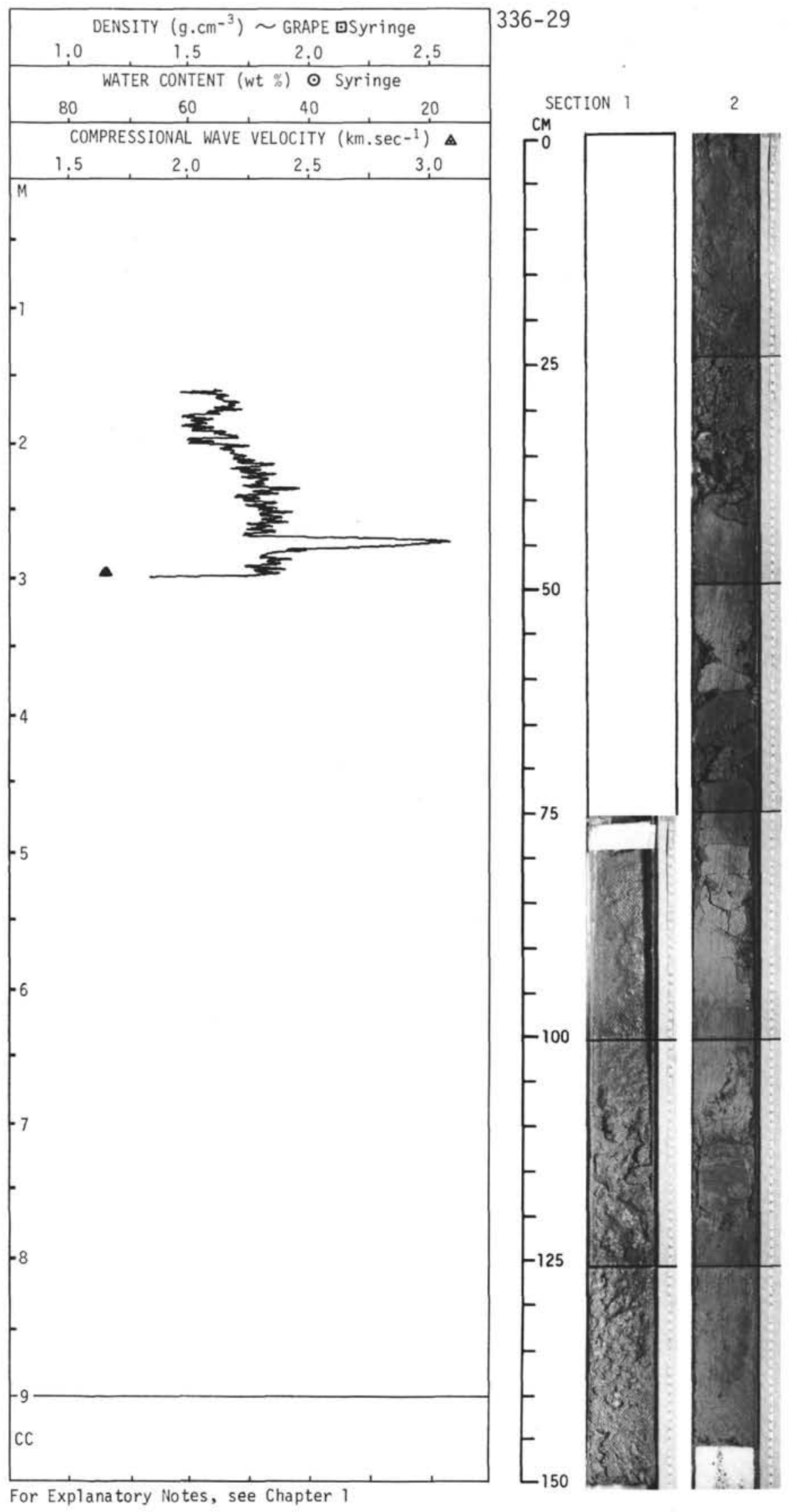




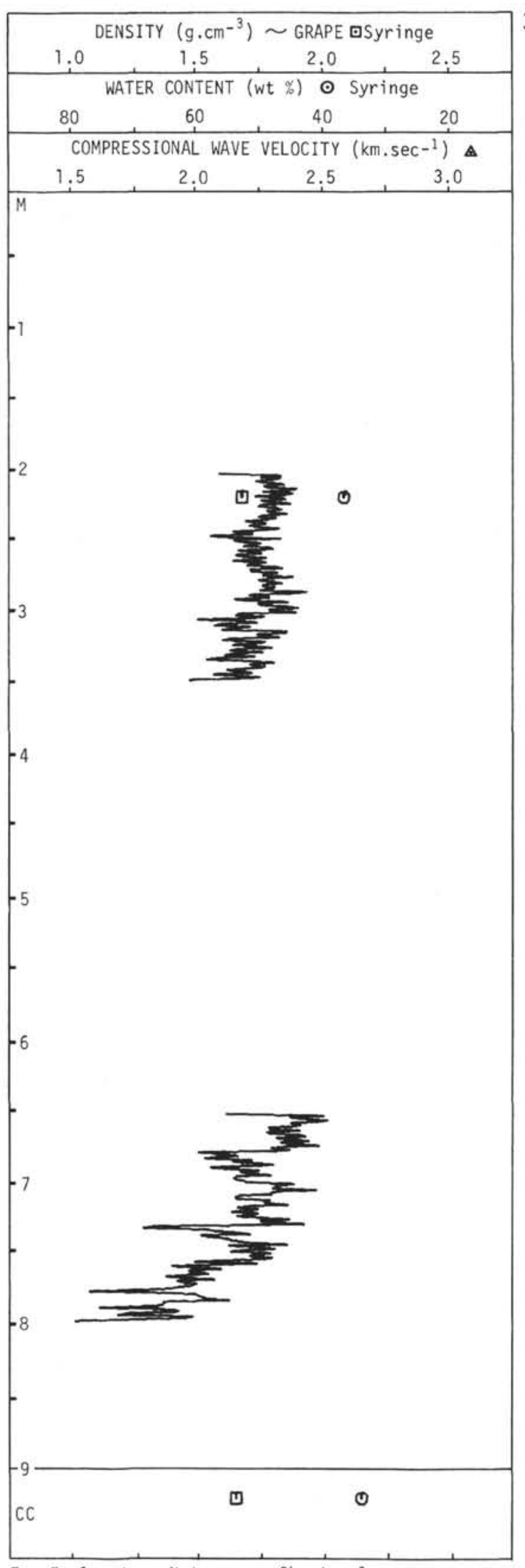

$336-30$

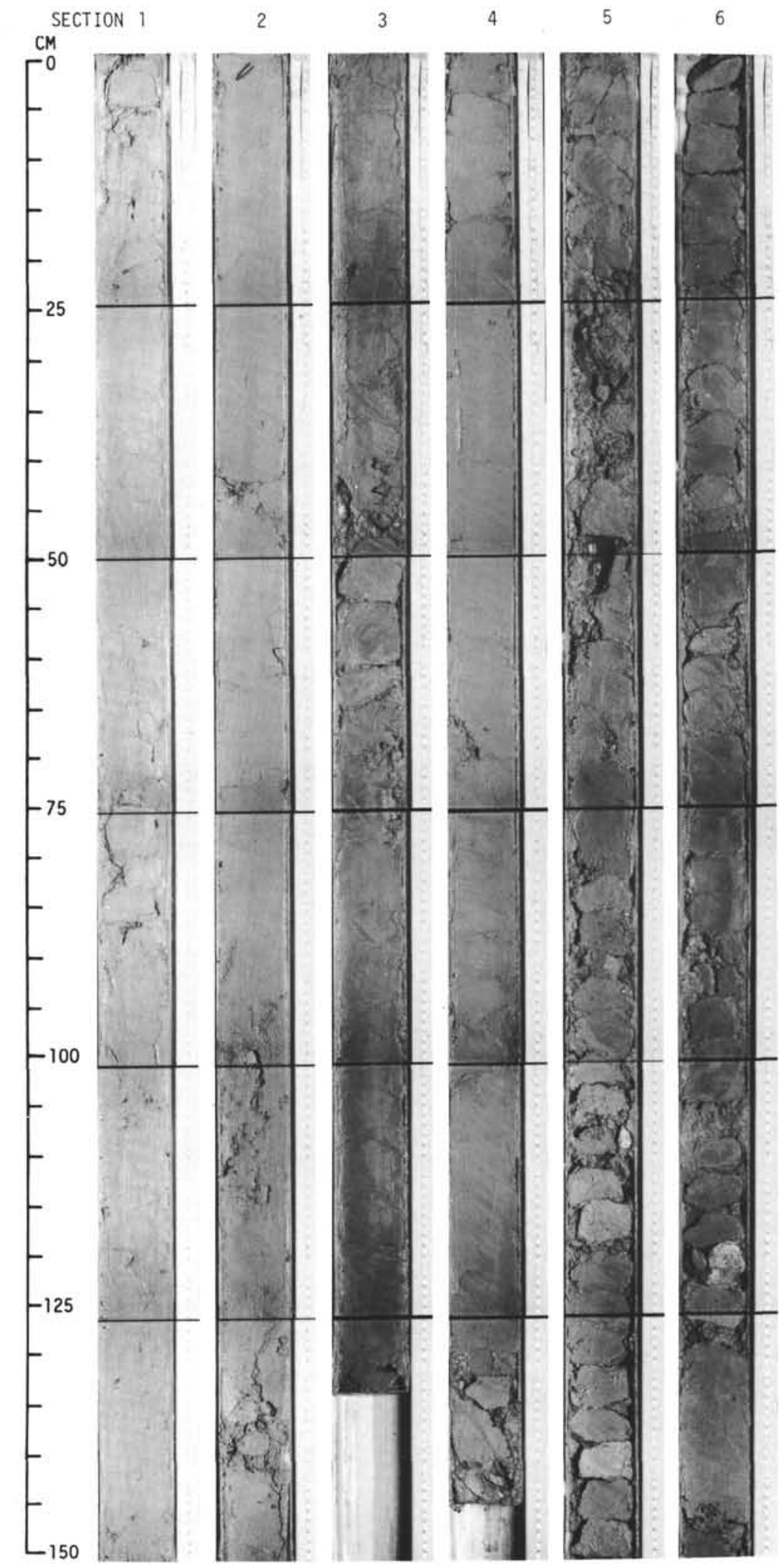




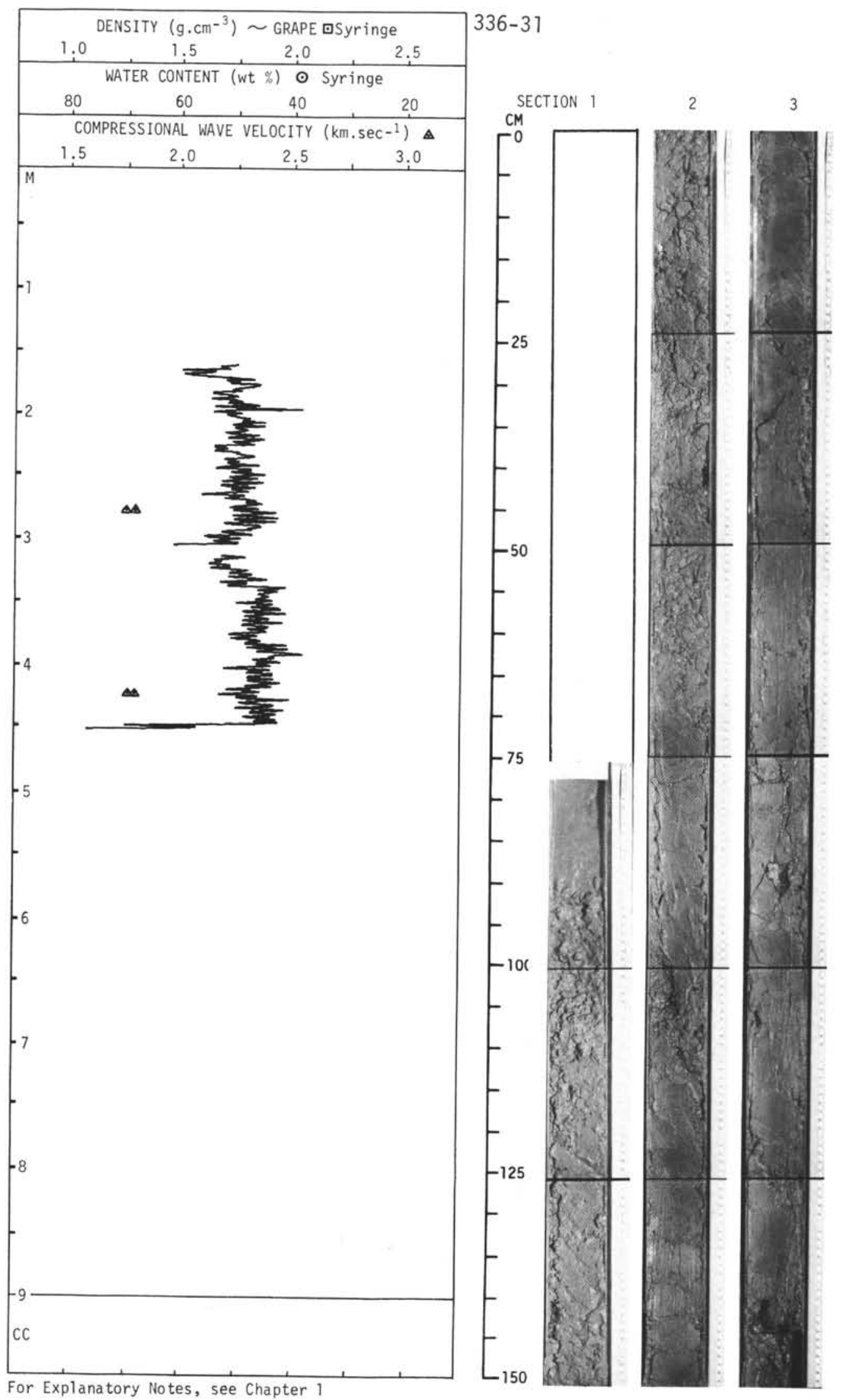




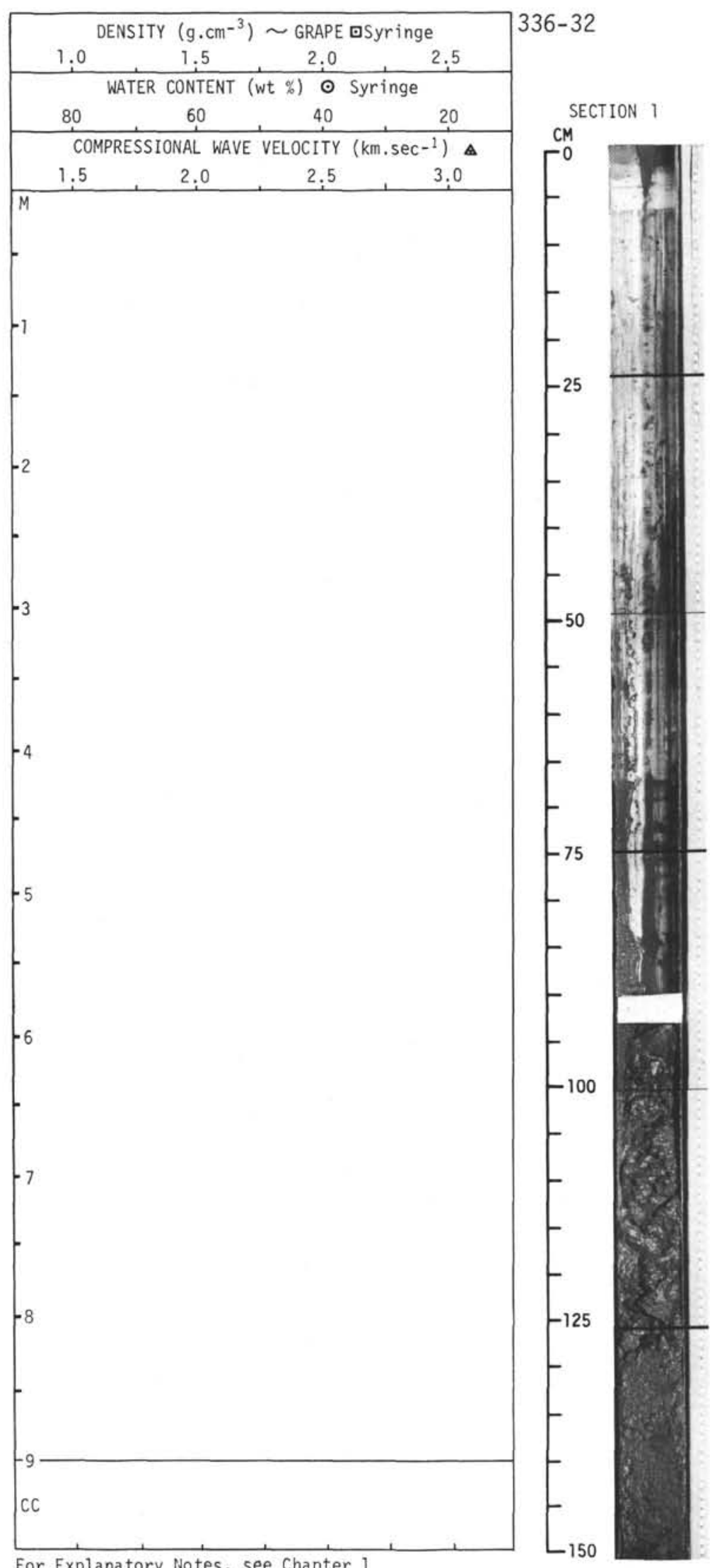




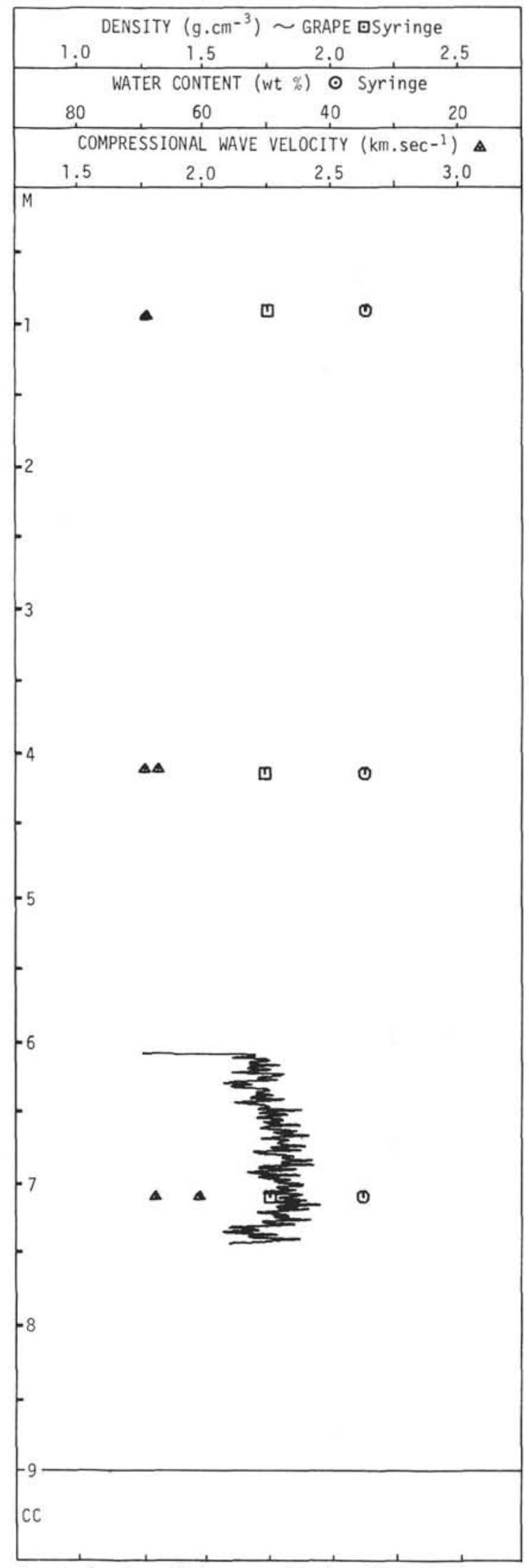

$336-33$

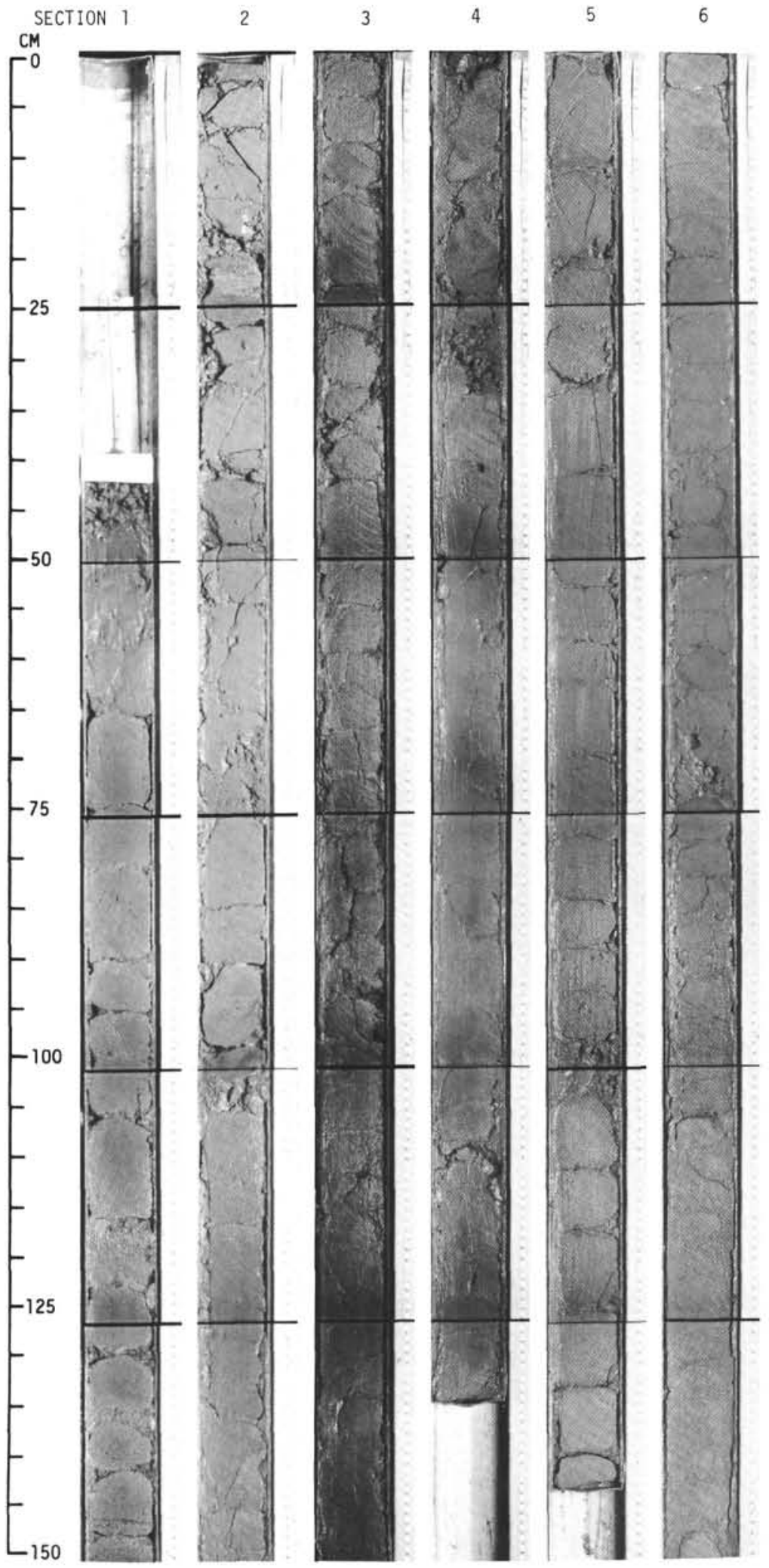

For Explanatory Notes, see Chapter 1 


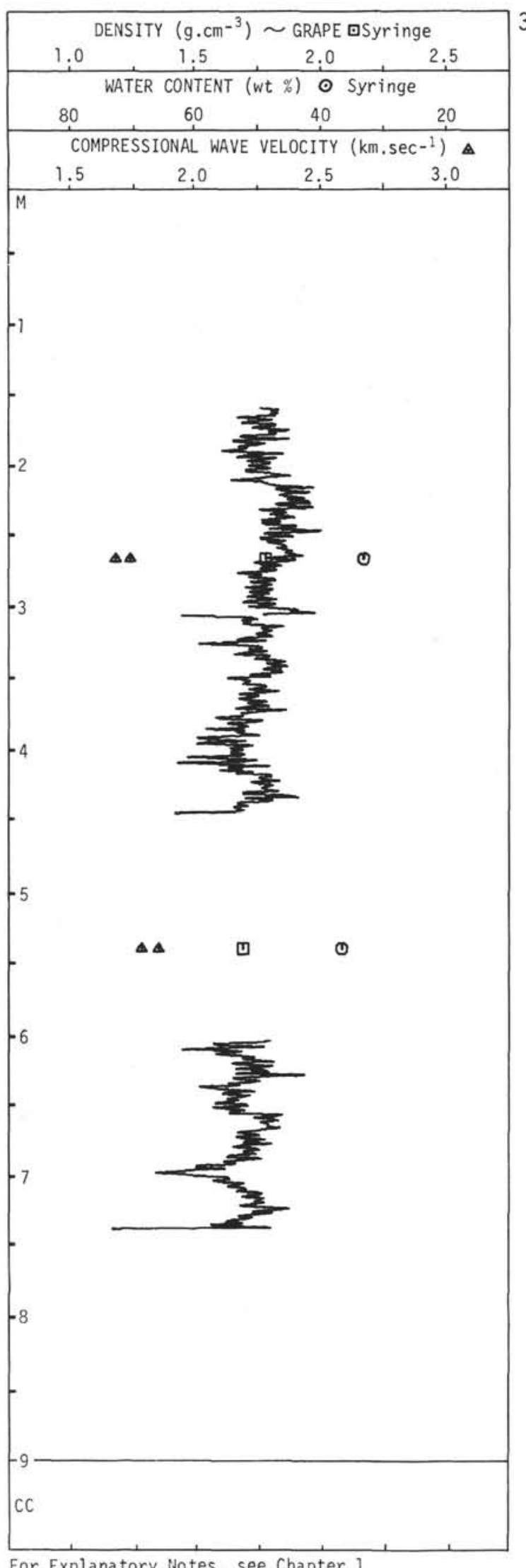

$336-35$

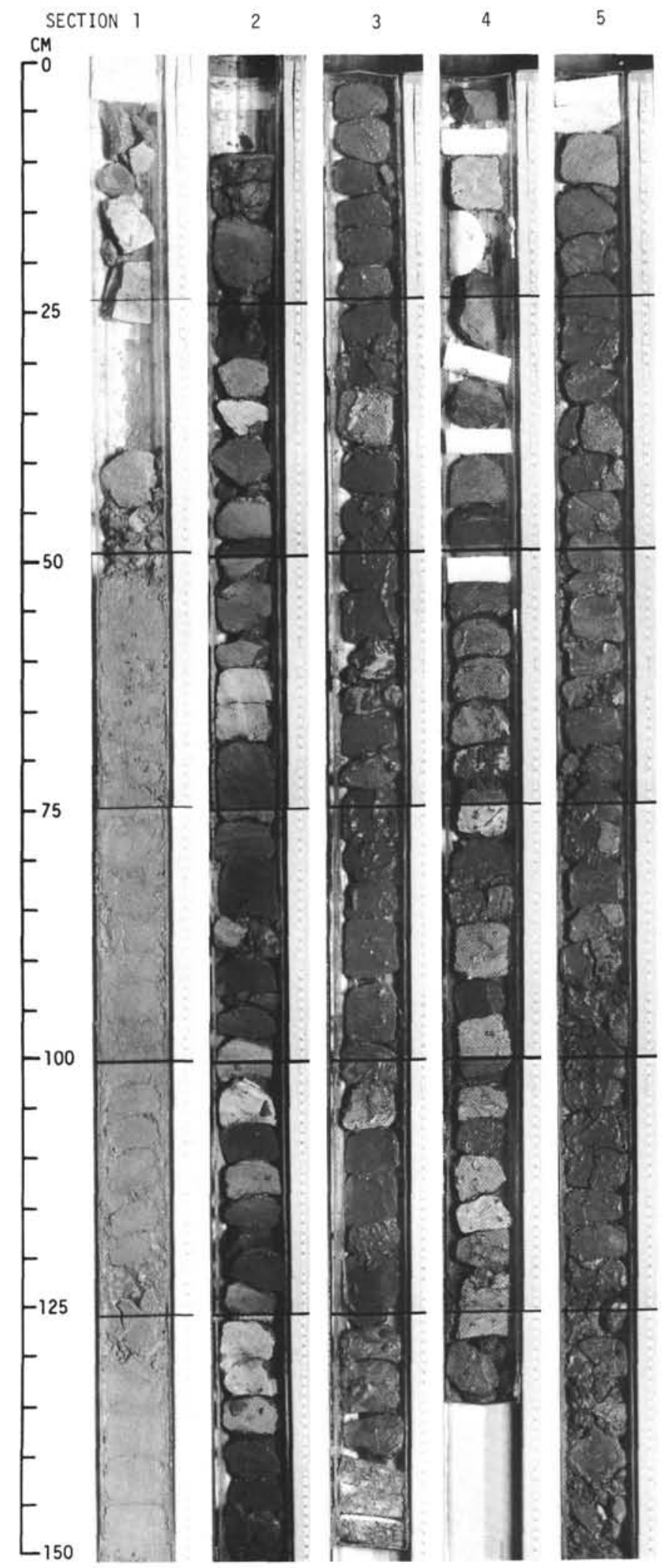




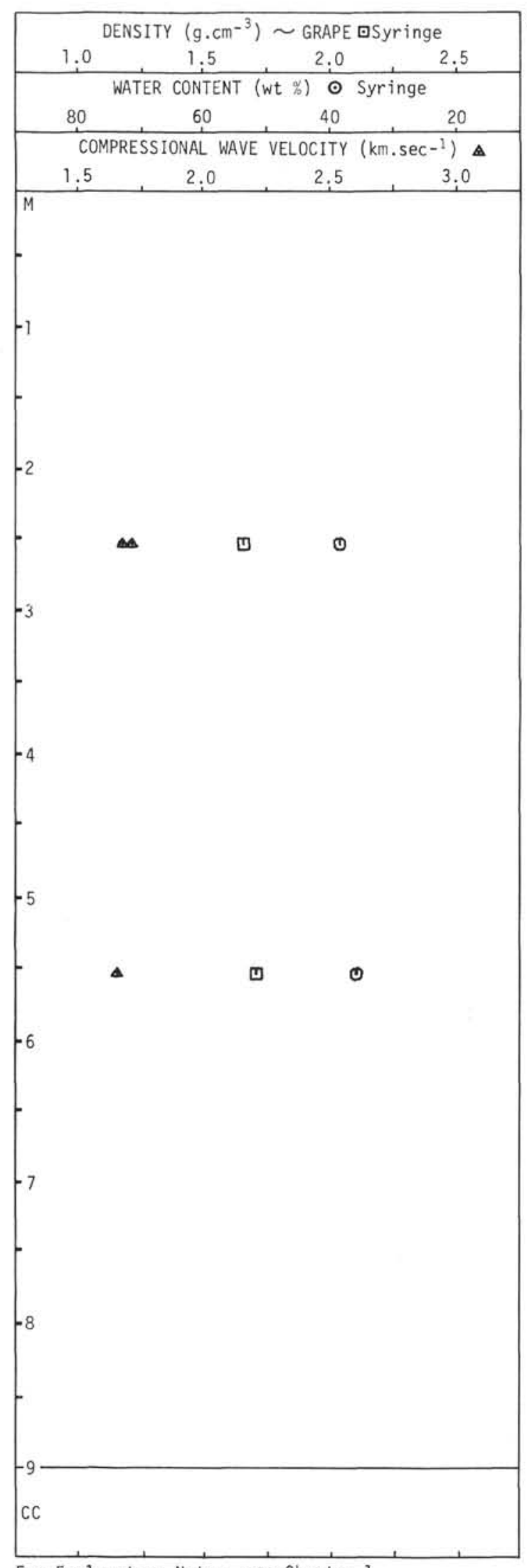

$336-36$

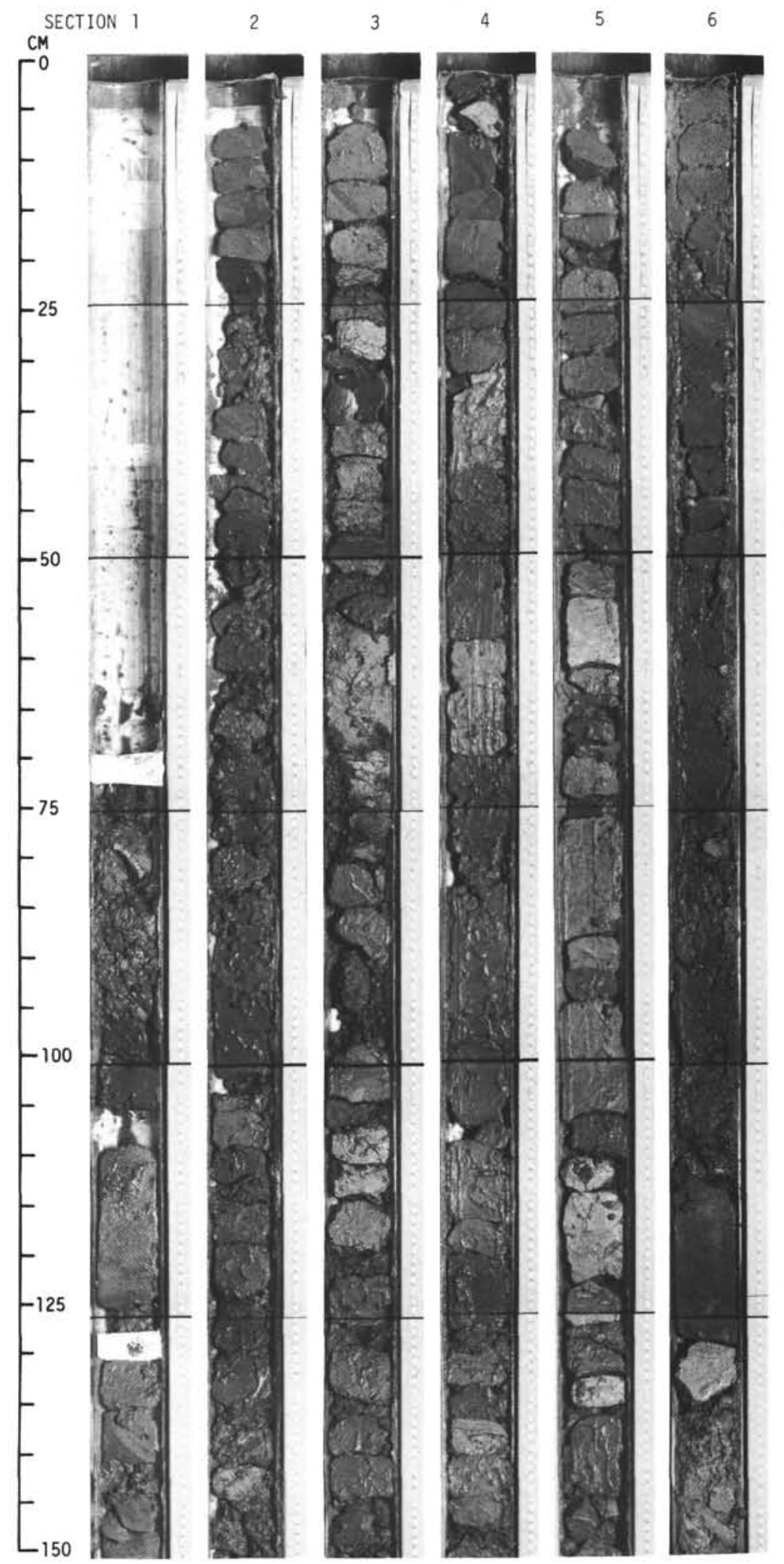




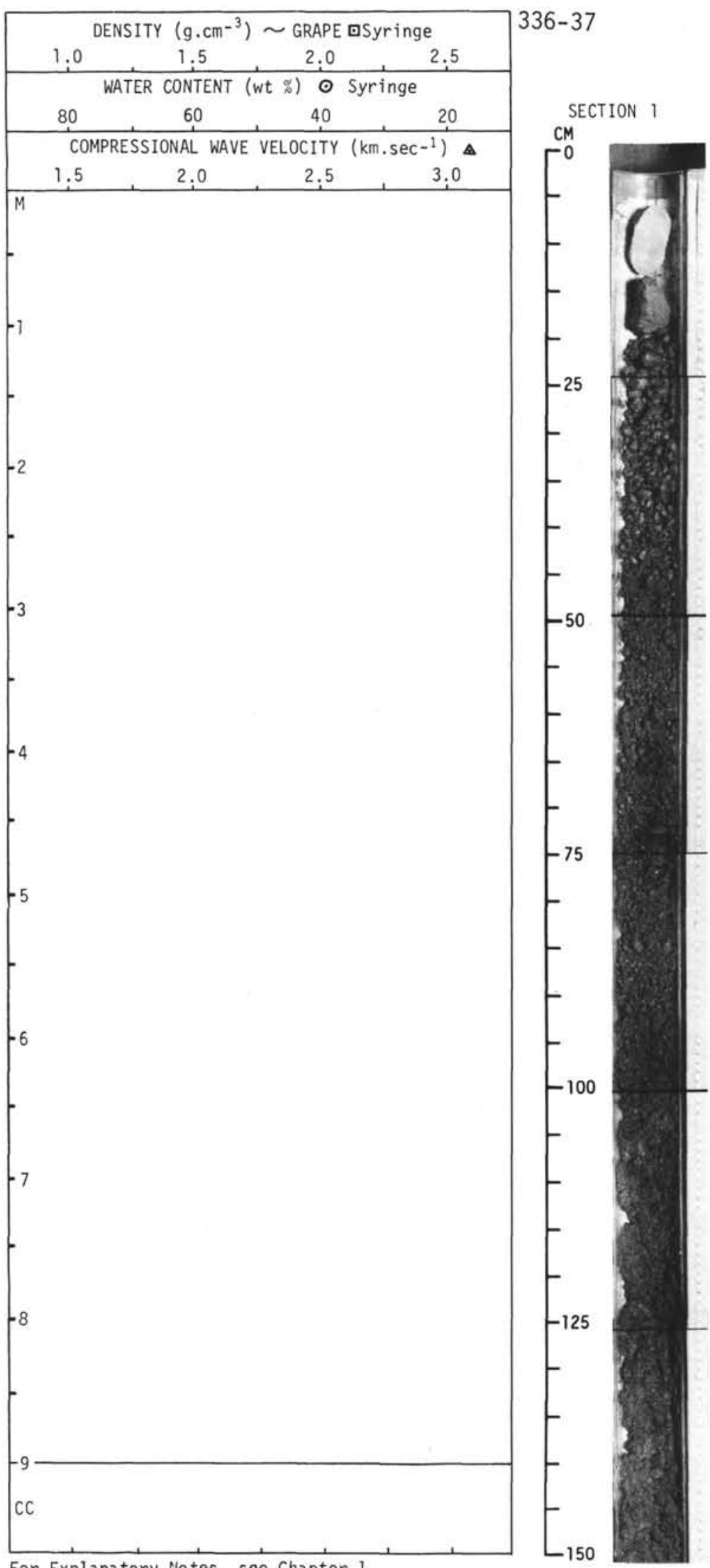




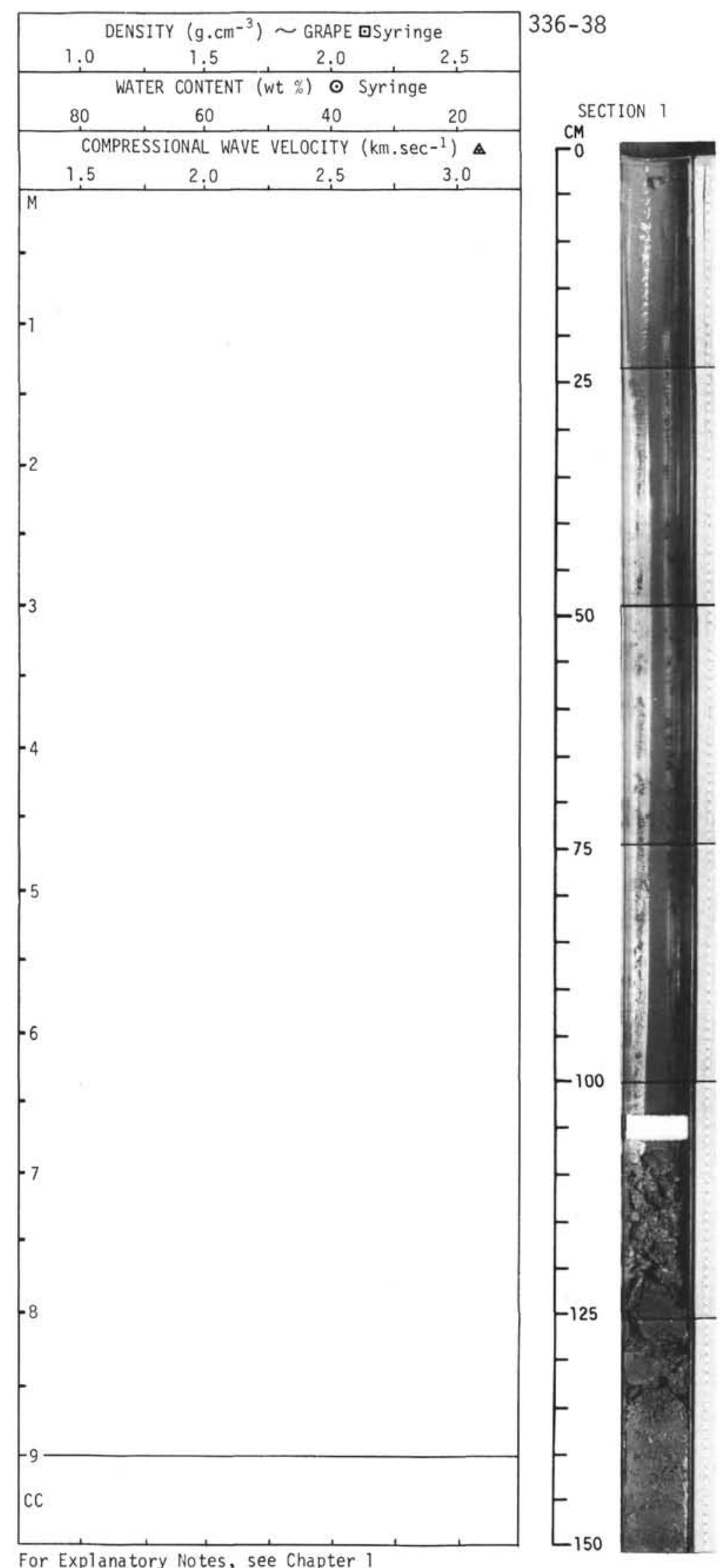




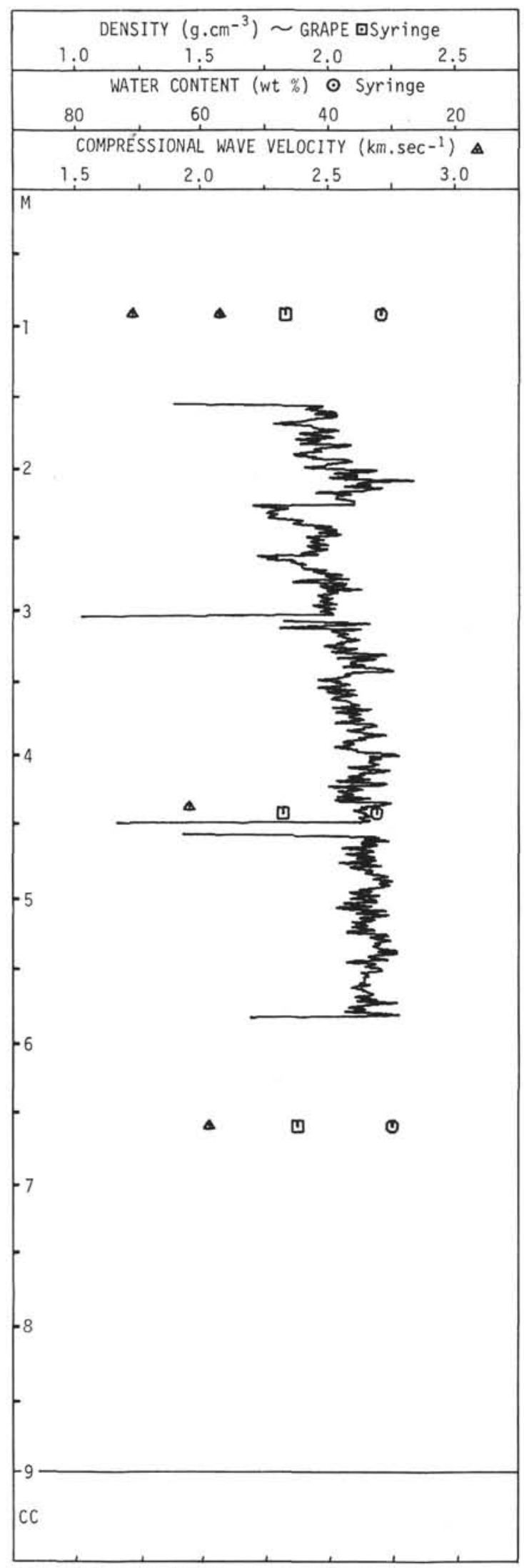

$336-39$

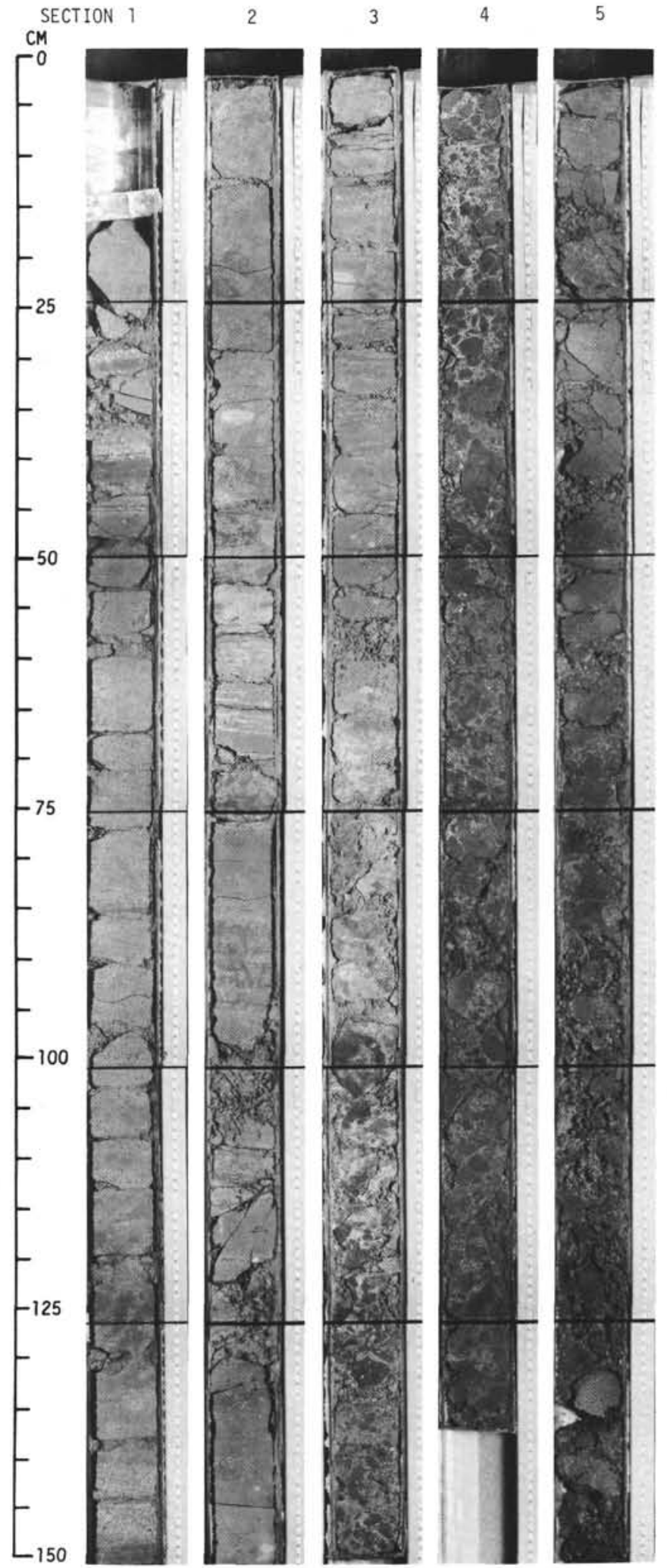


SITES 336 AND 352

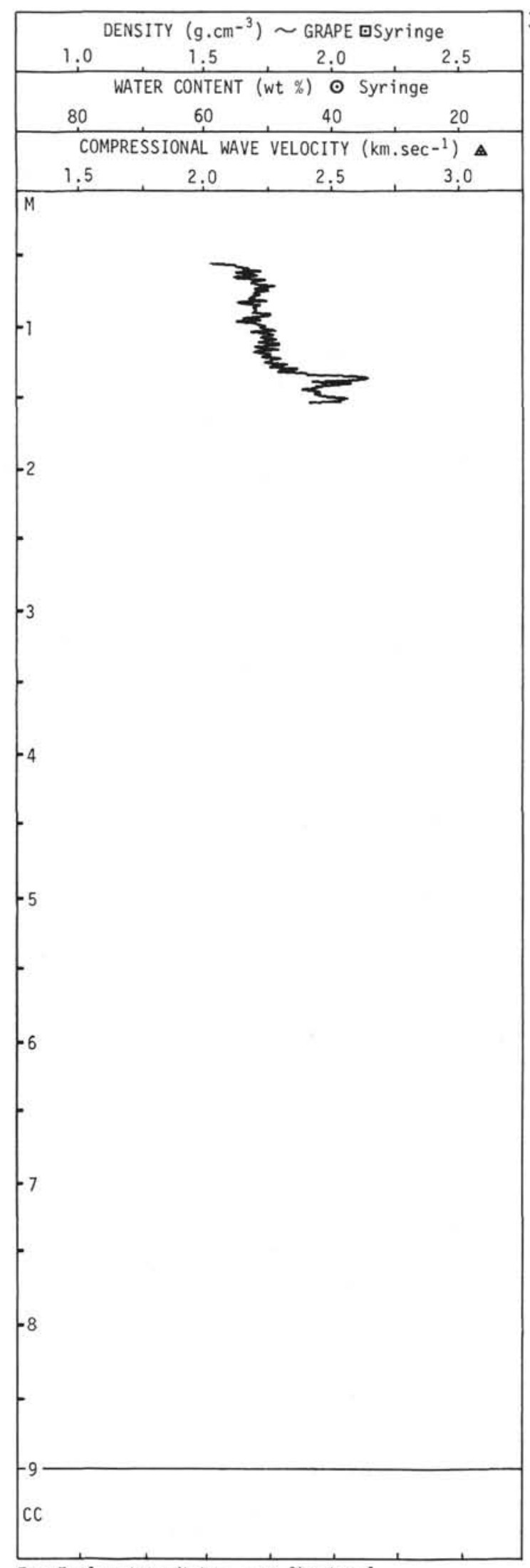

$336-40$

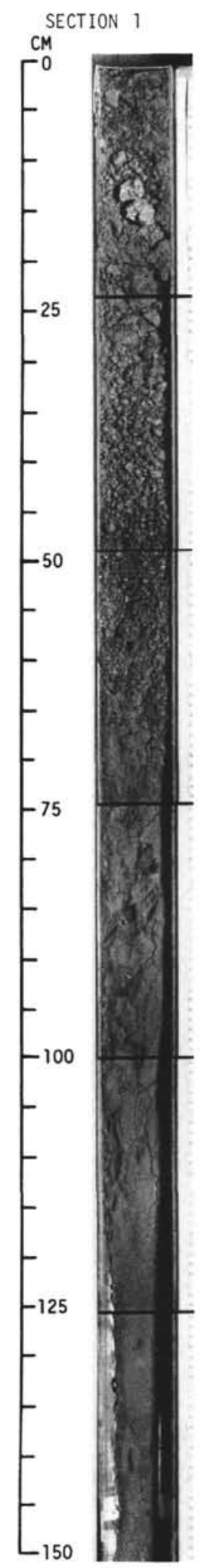

102 


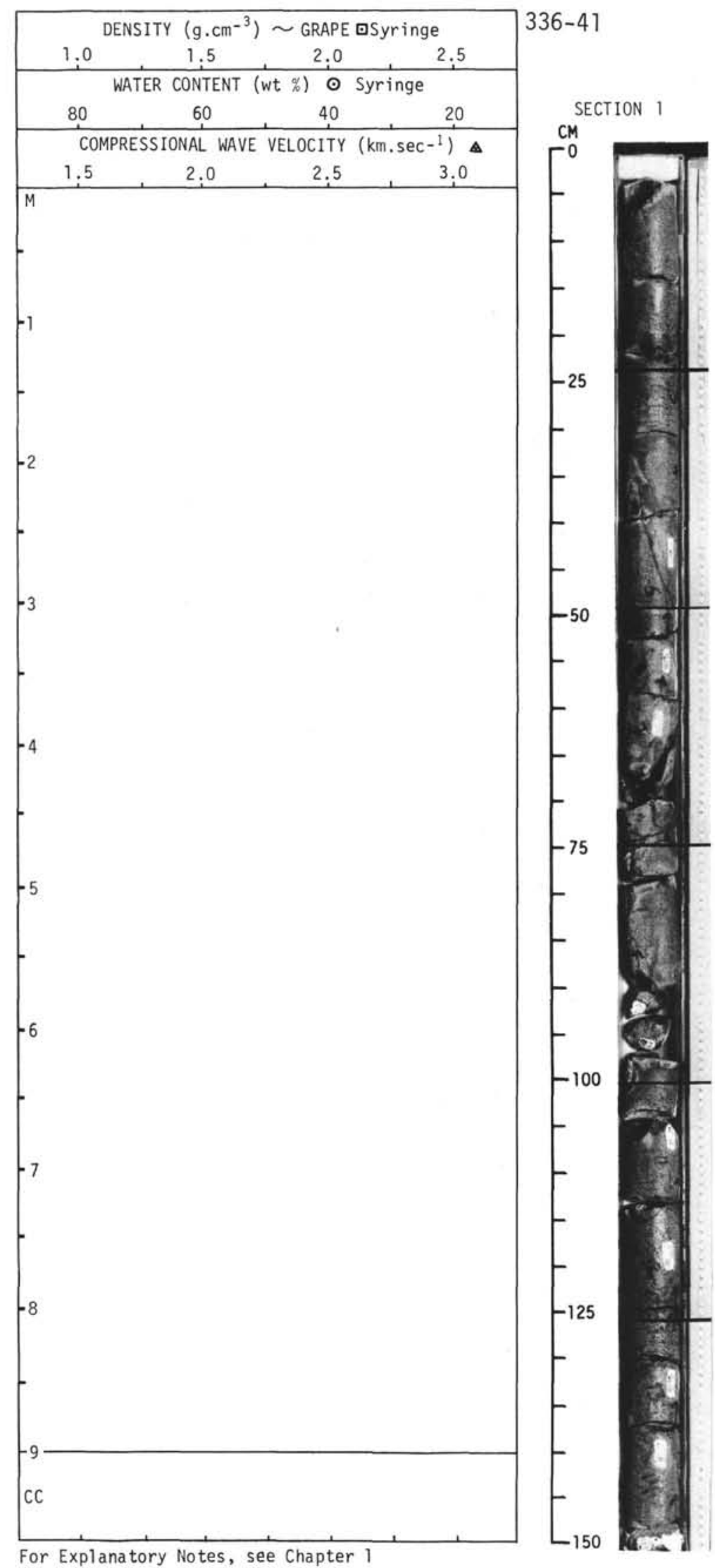




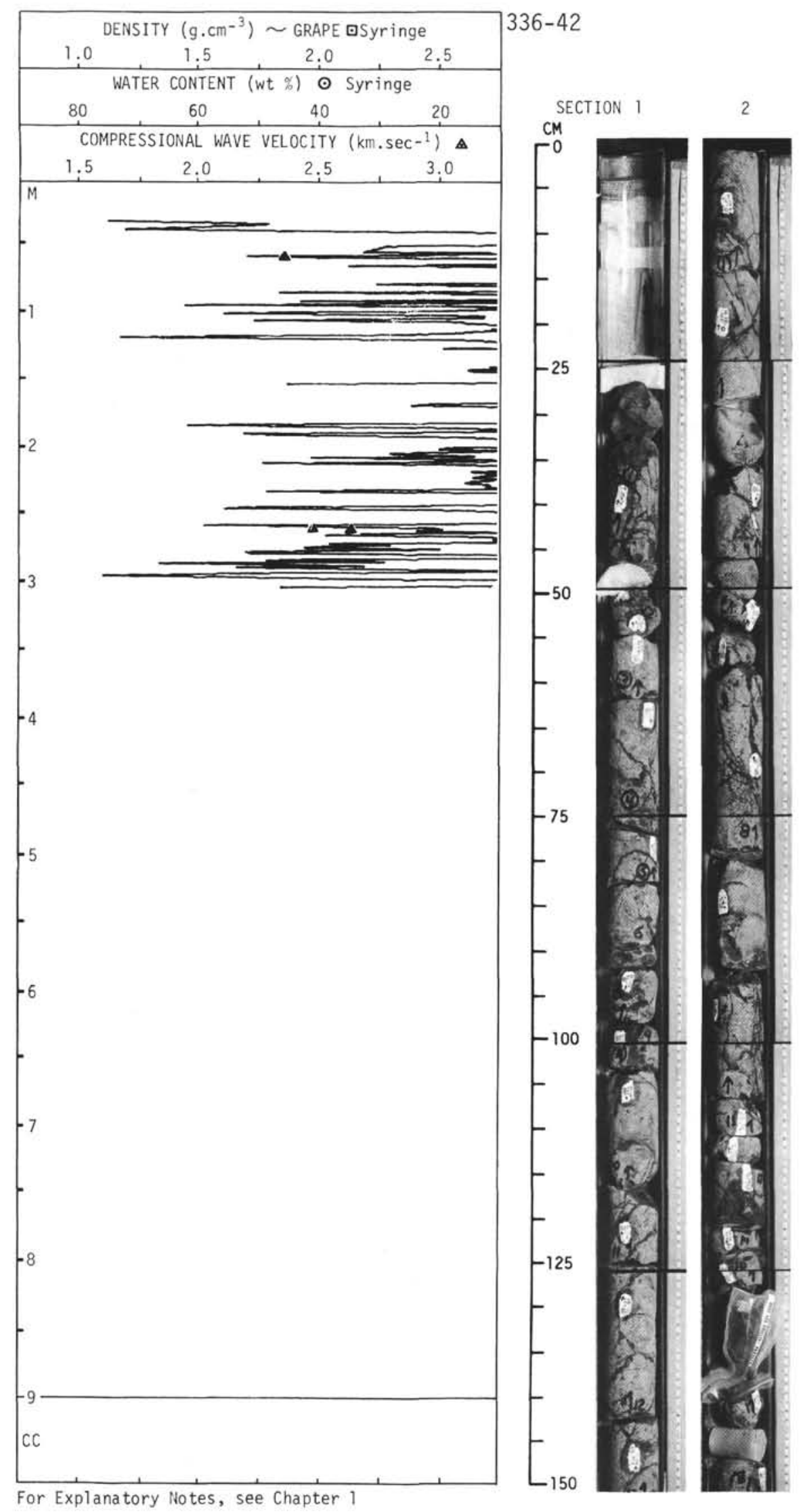




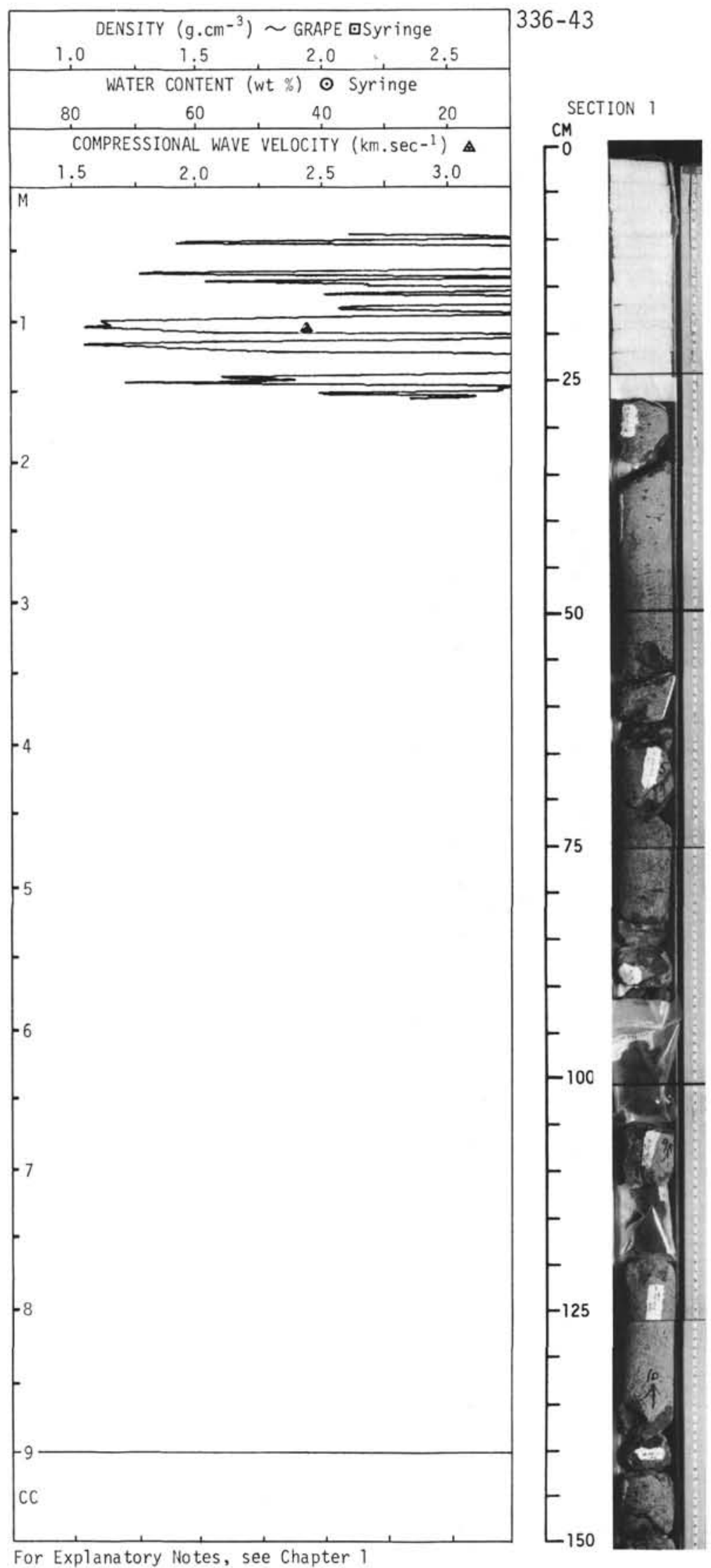




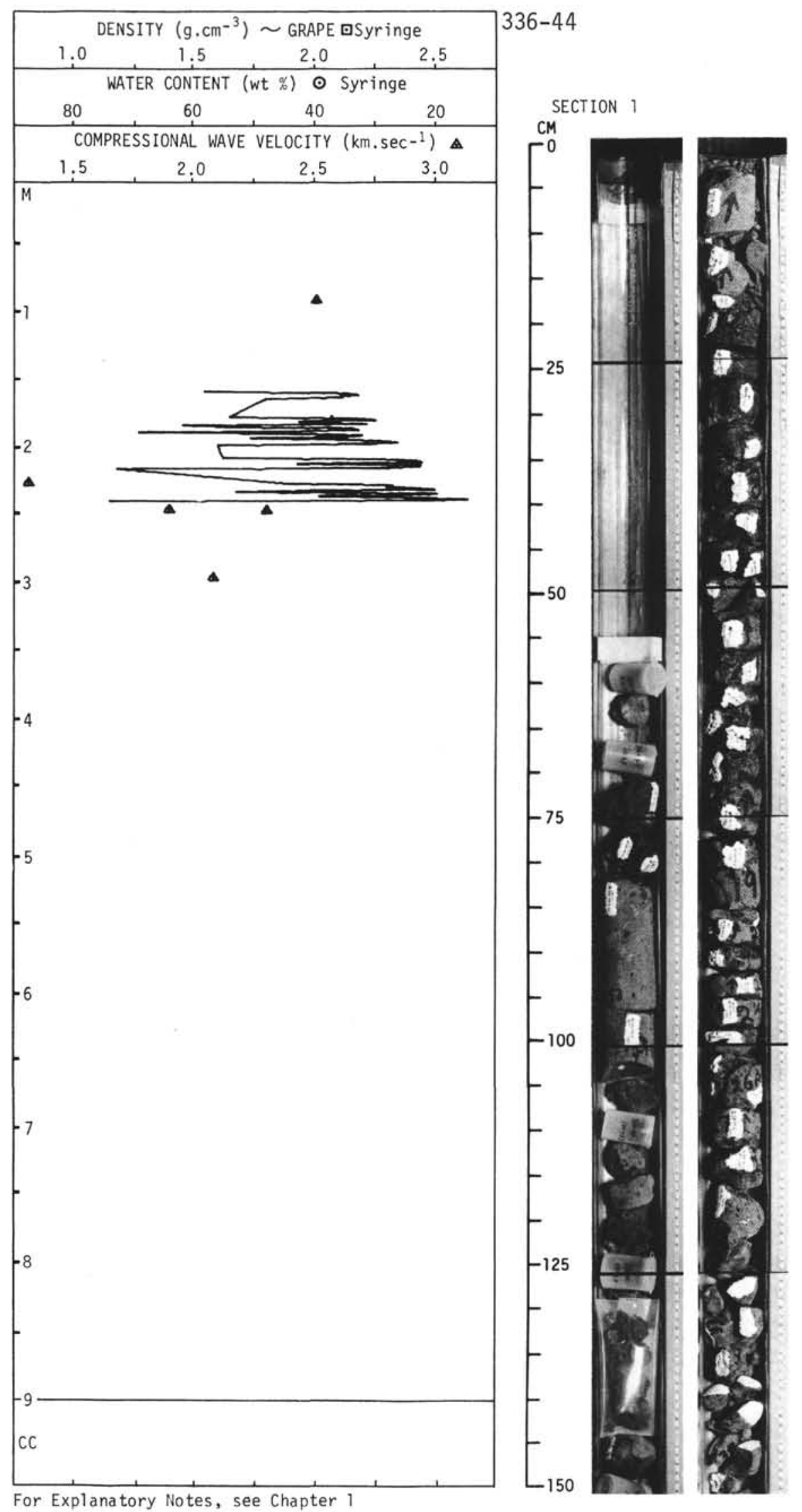




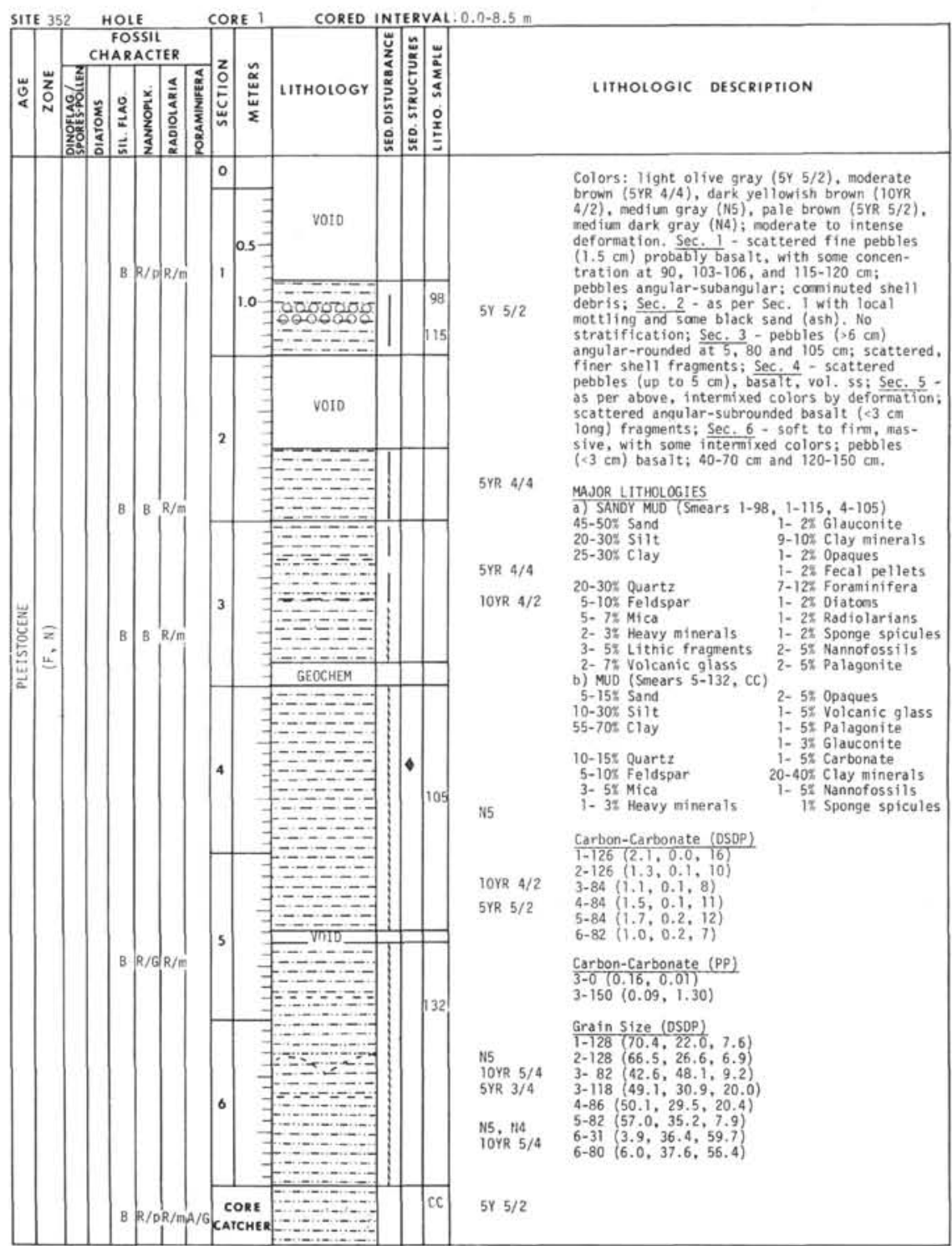

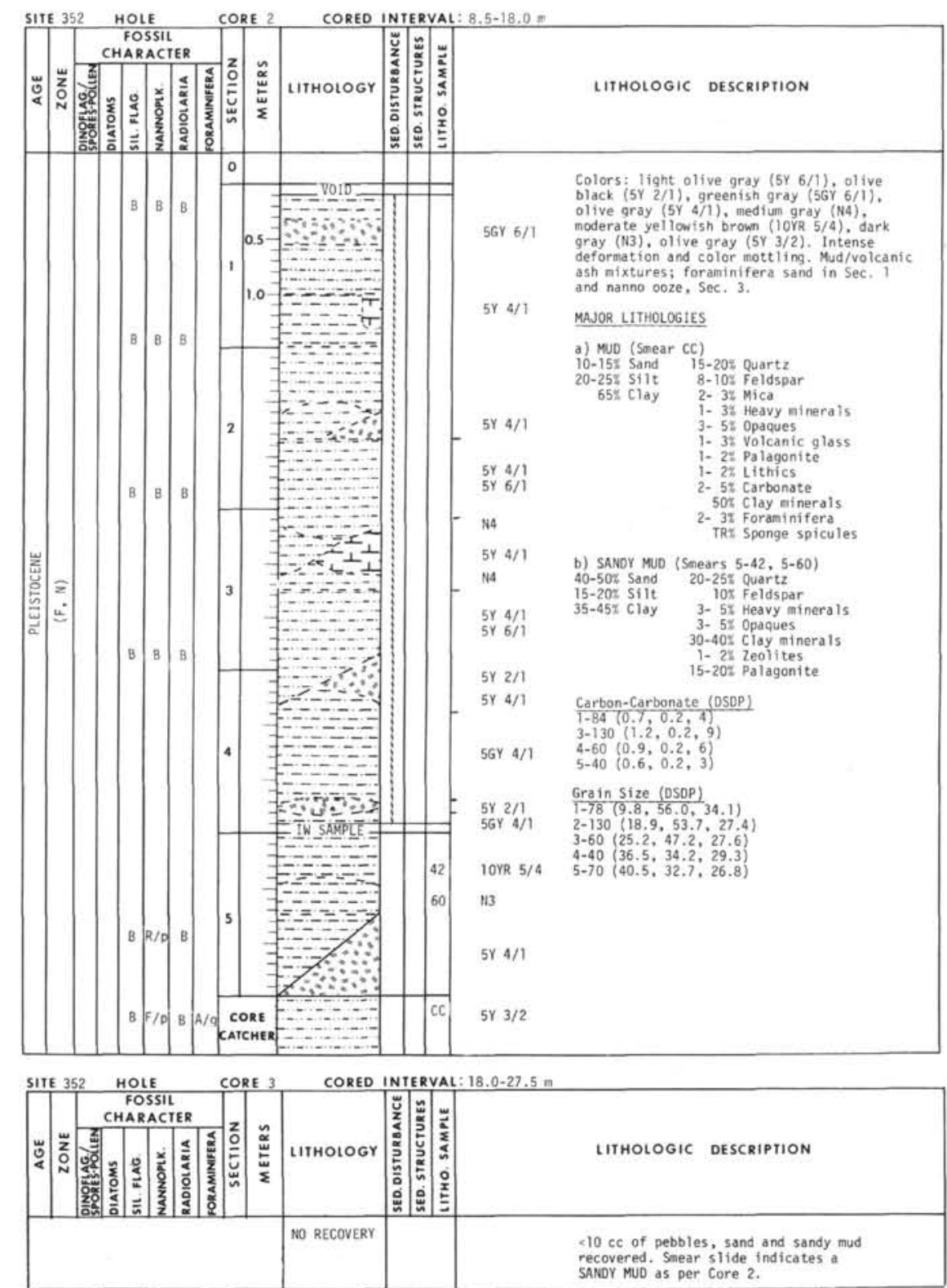



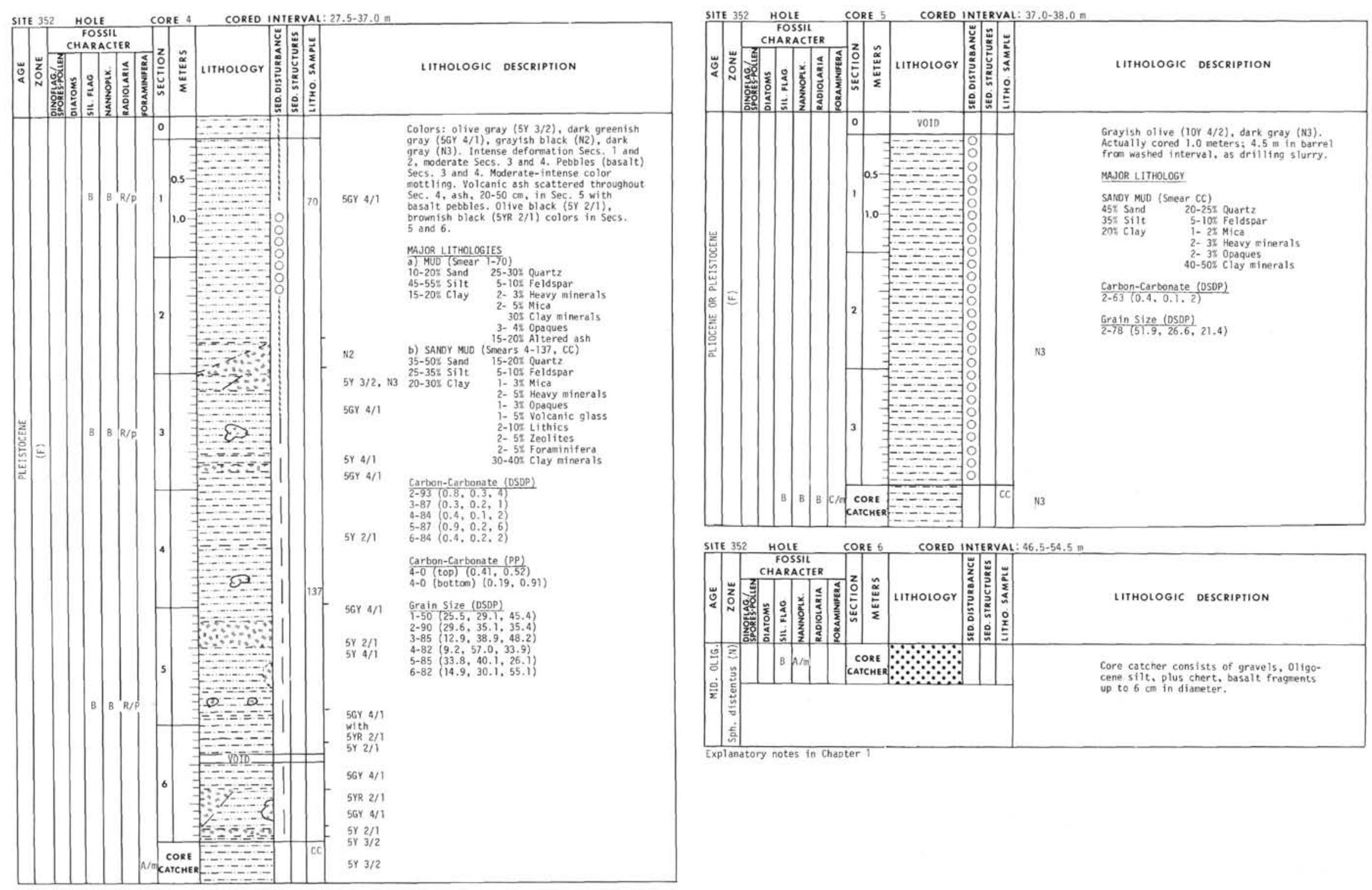


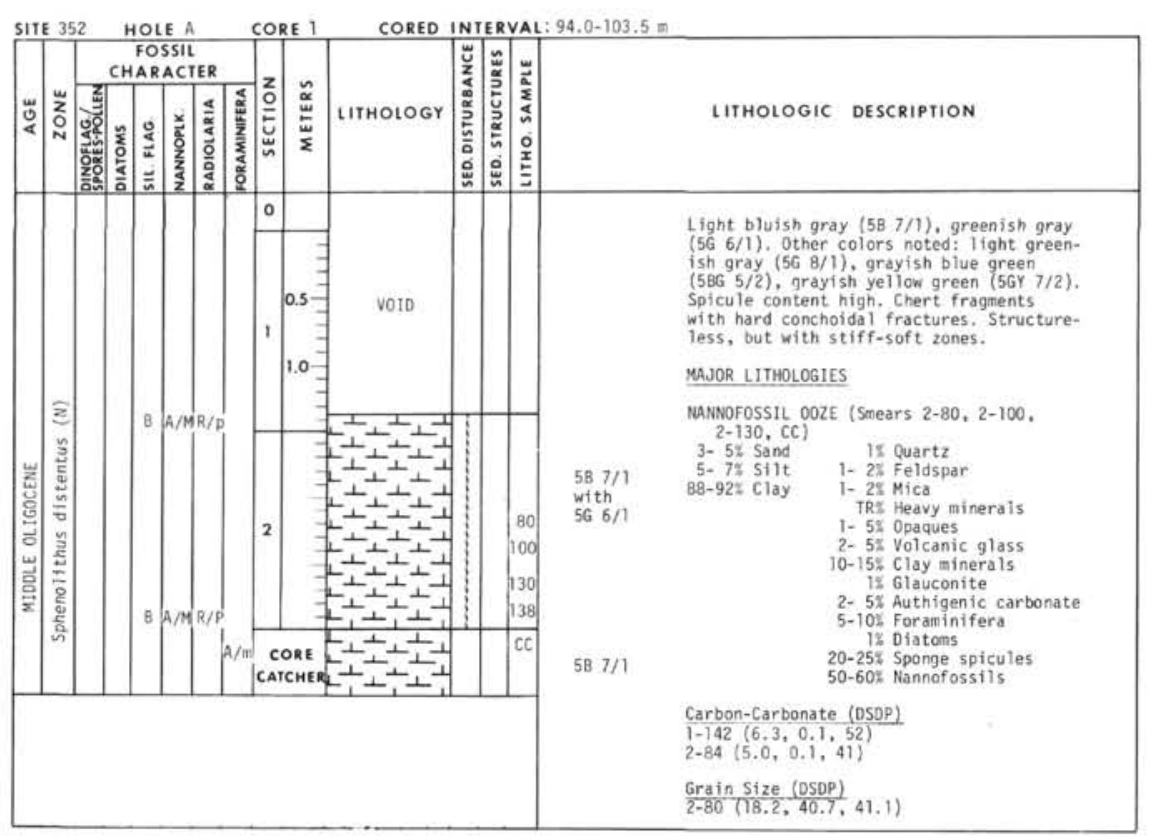

SIIE 352 HOLEA CORE 2 CORED INTERVAL: $103.5-113.0 \mathrm{~m}$

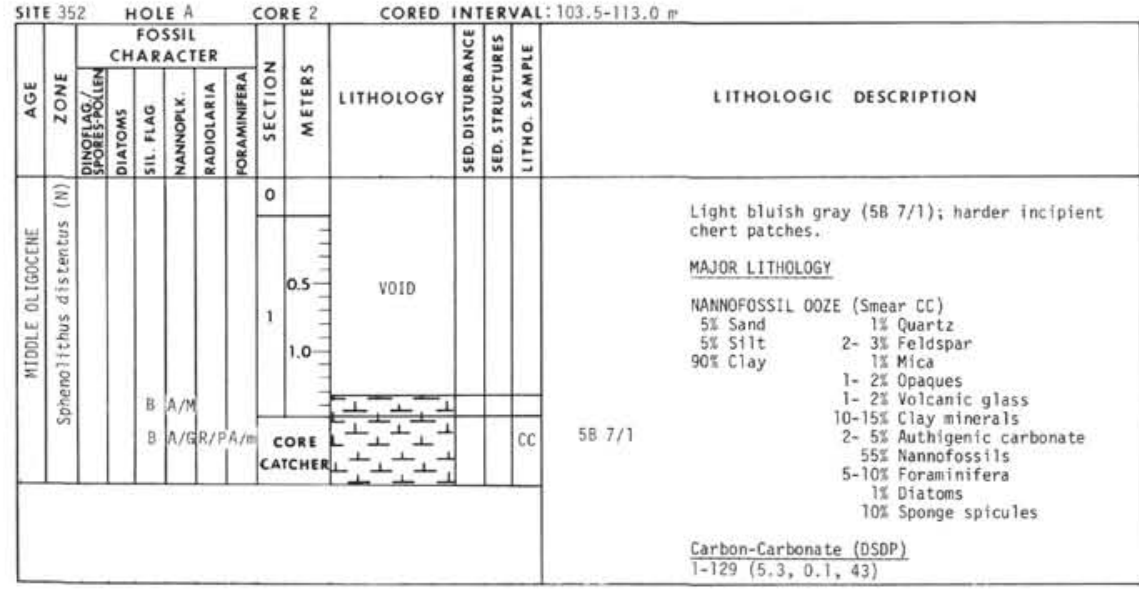

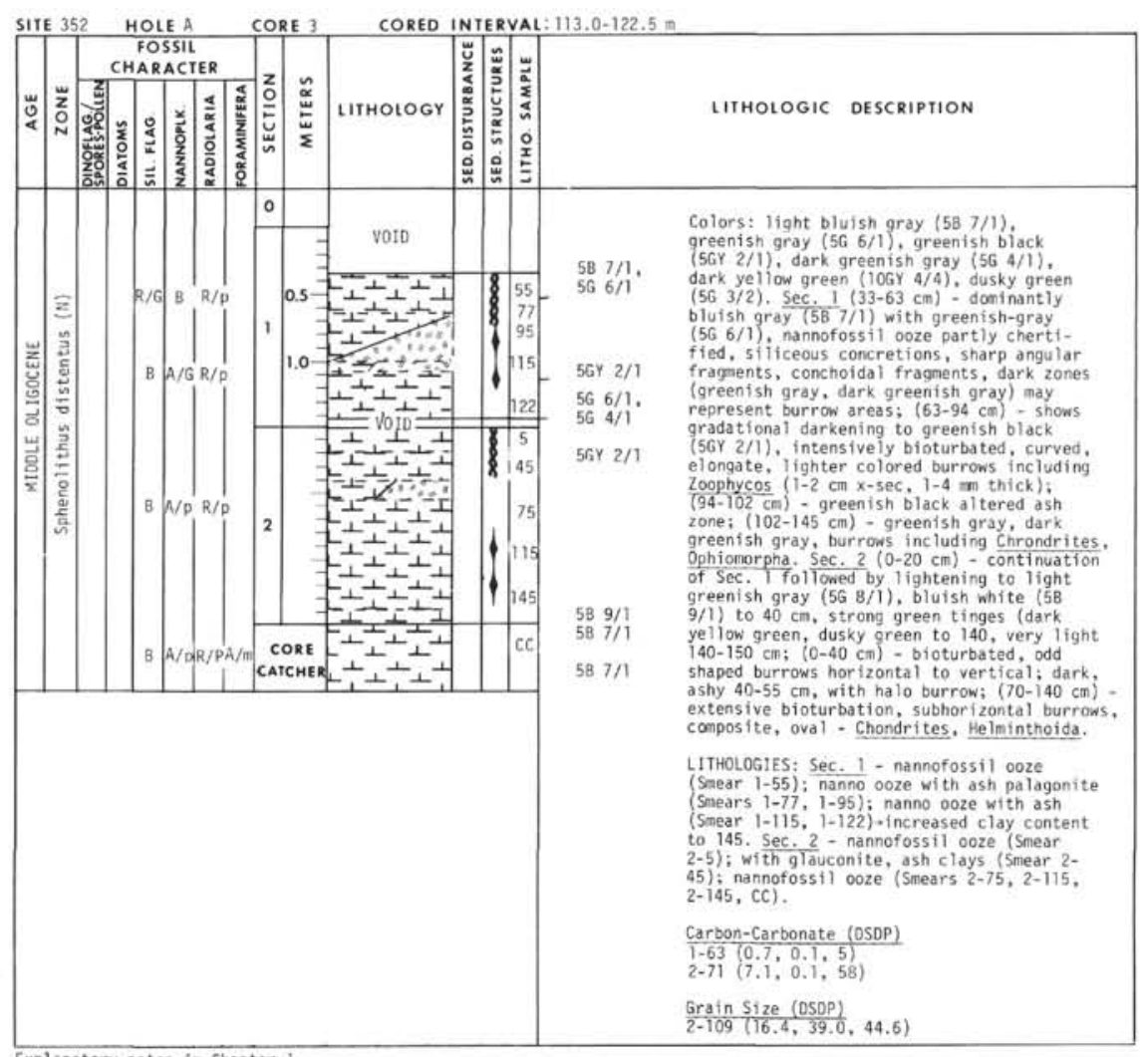

Explanatory notes in Chapter 


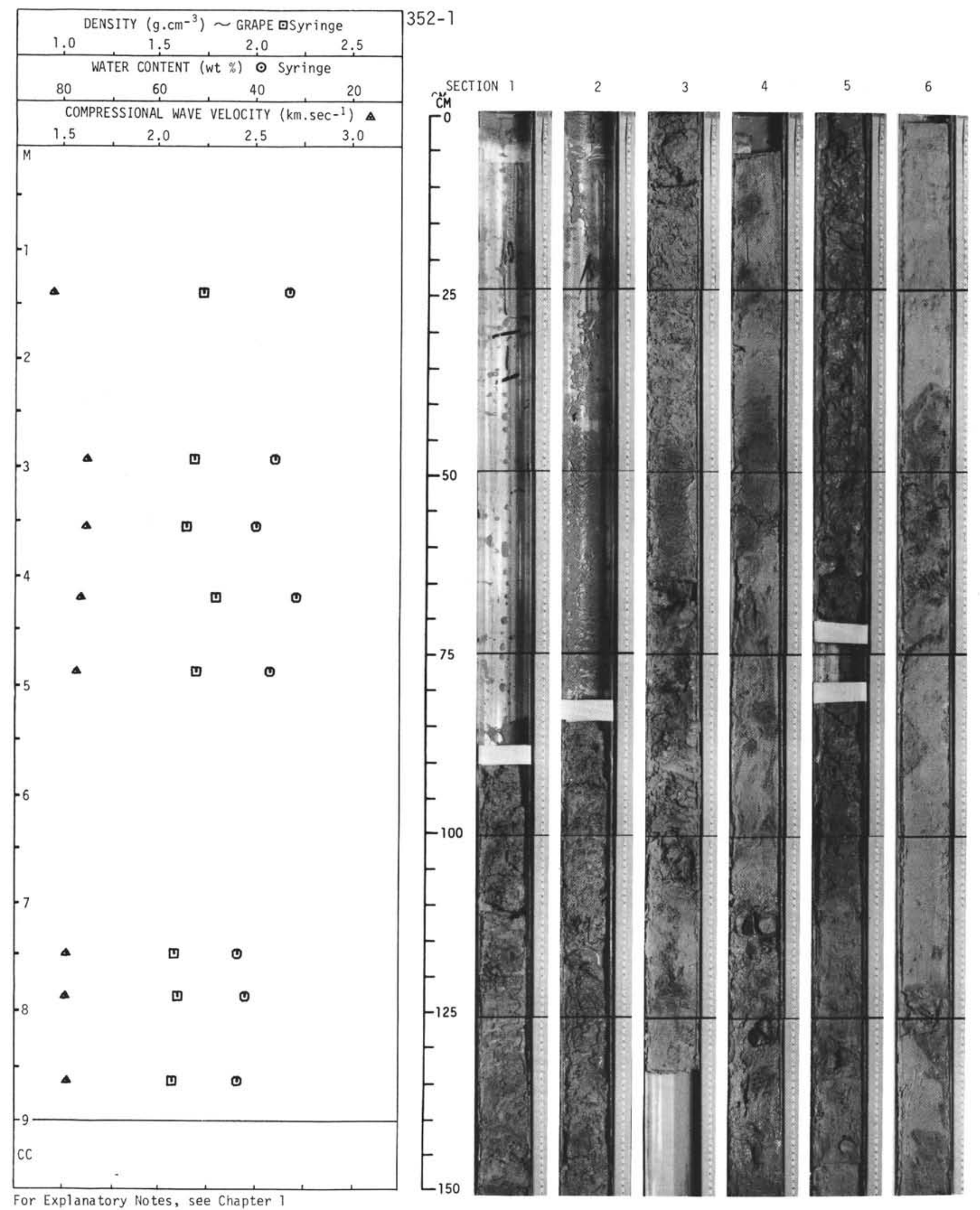




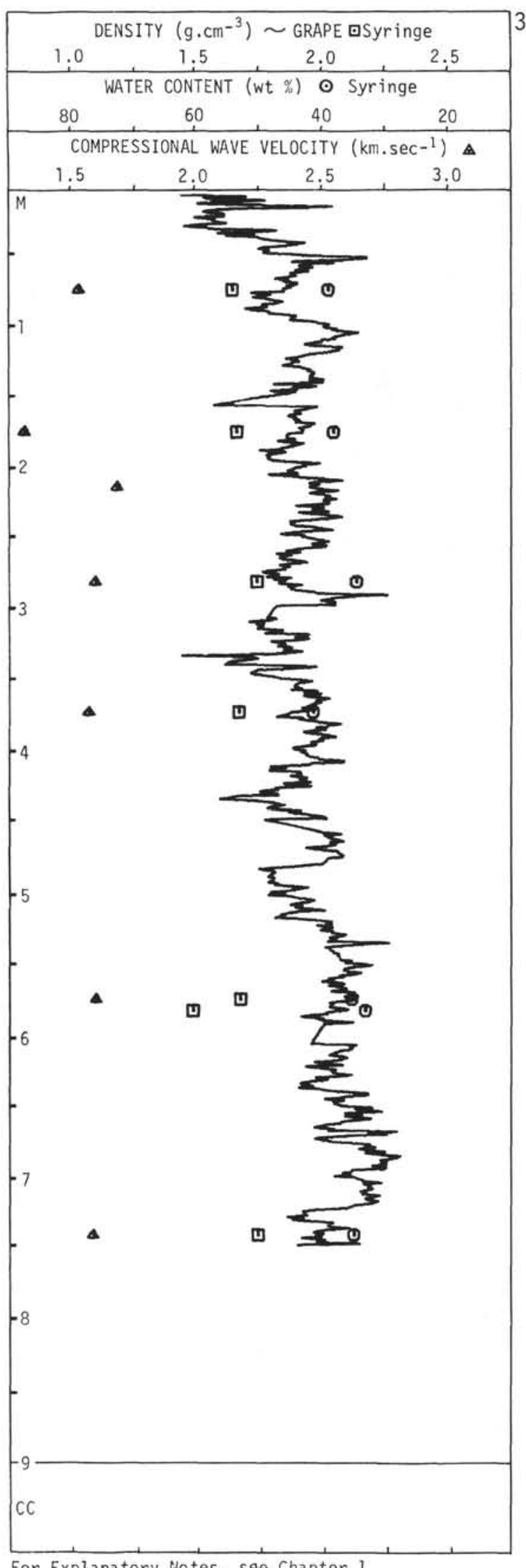

352-2

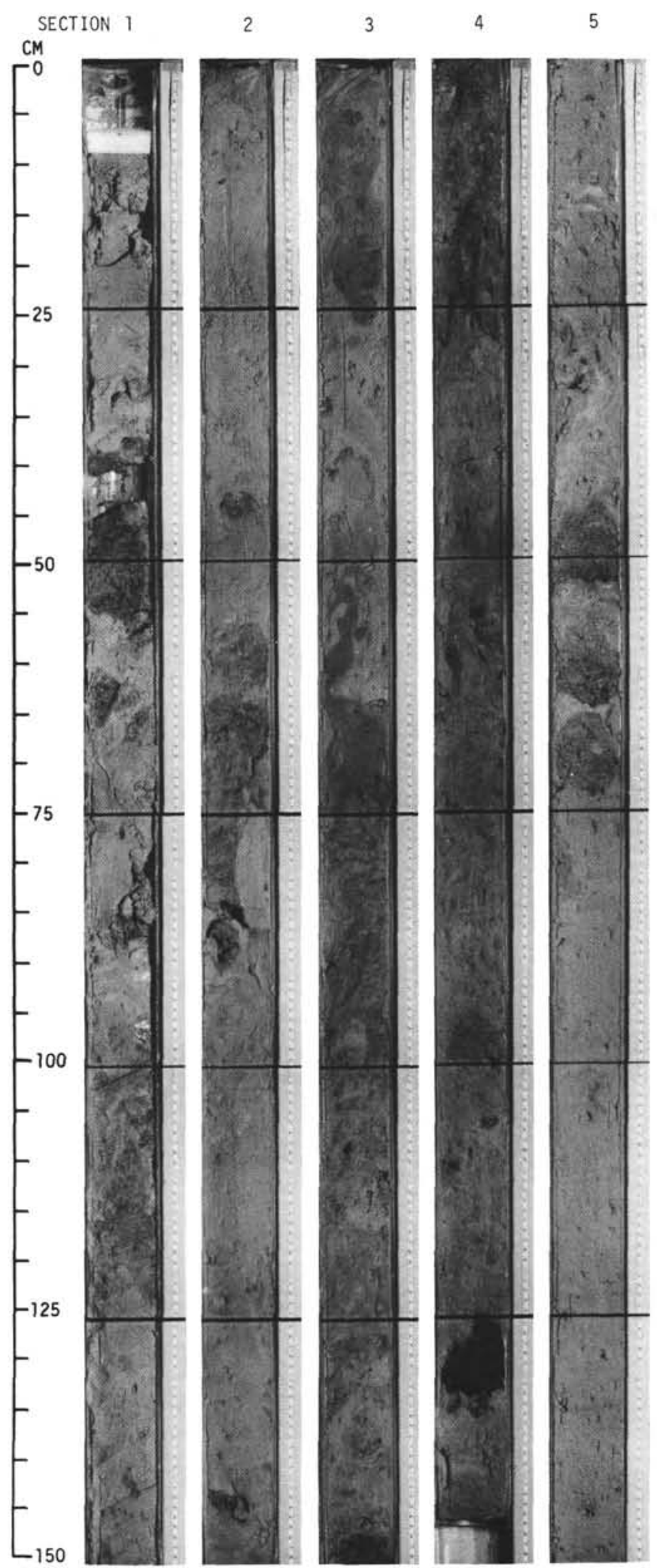




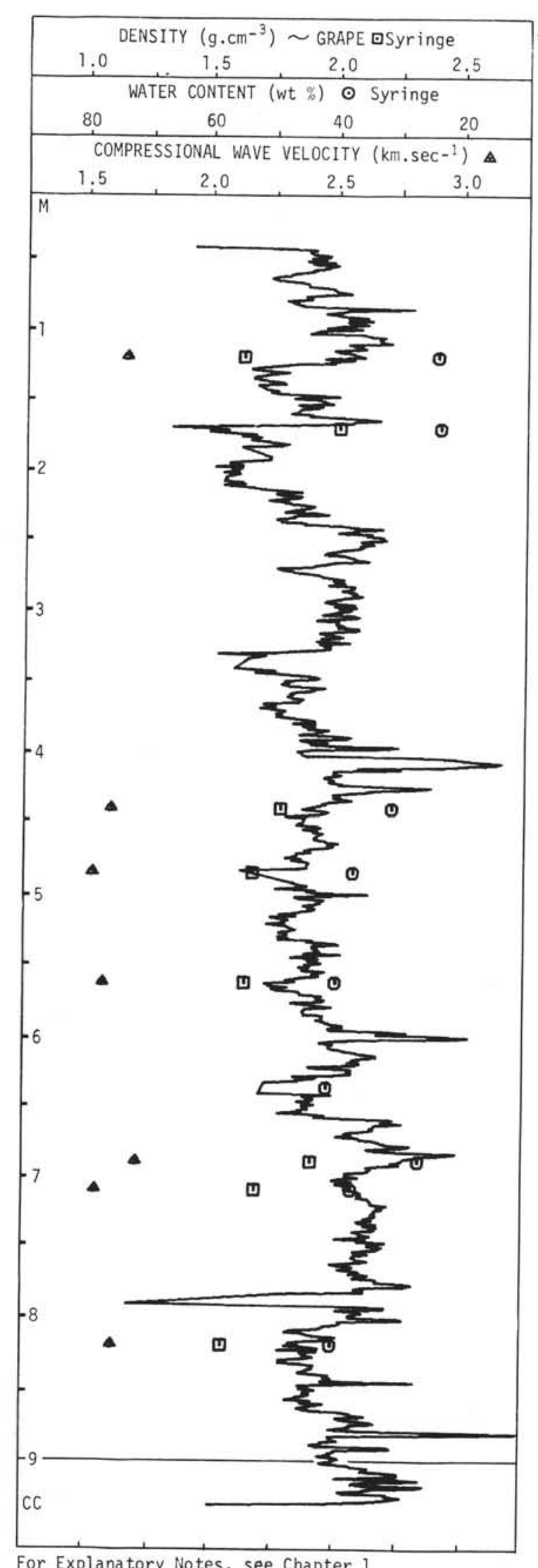

\section{$352-4$}

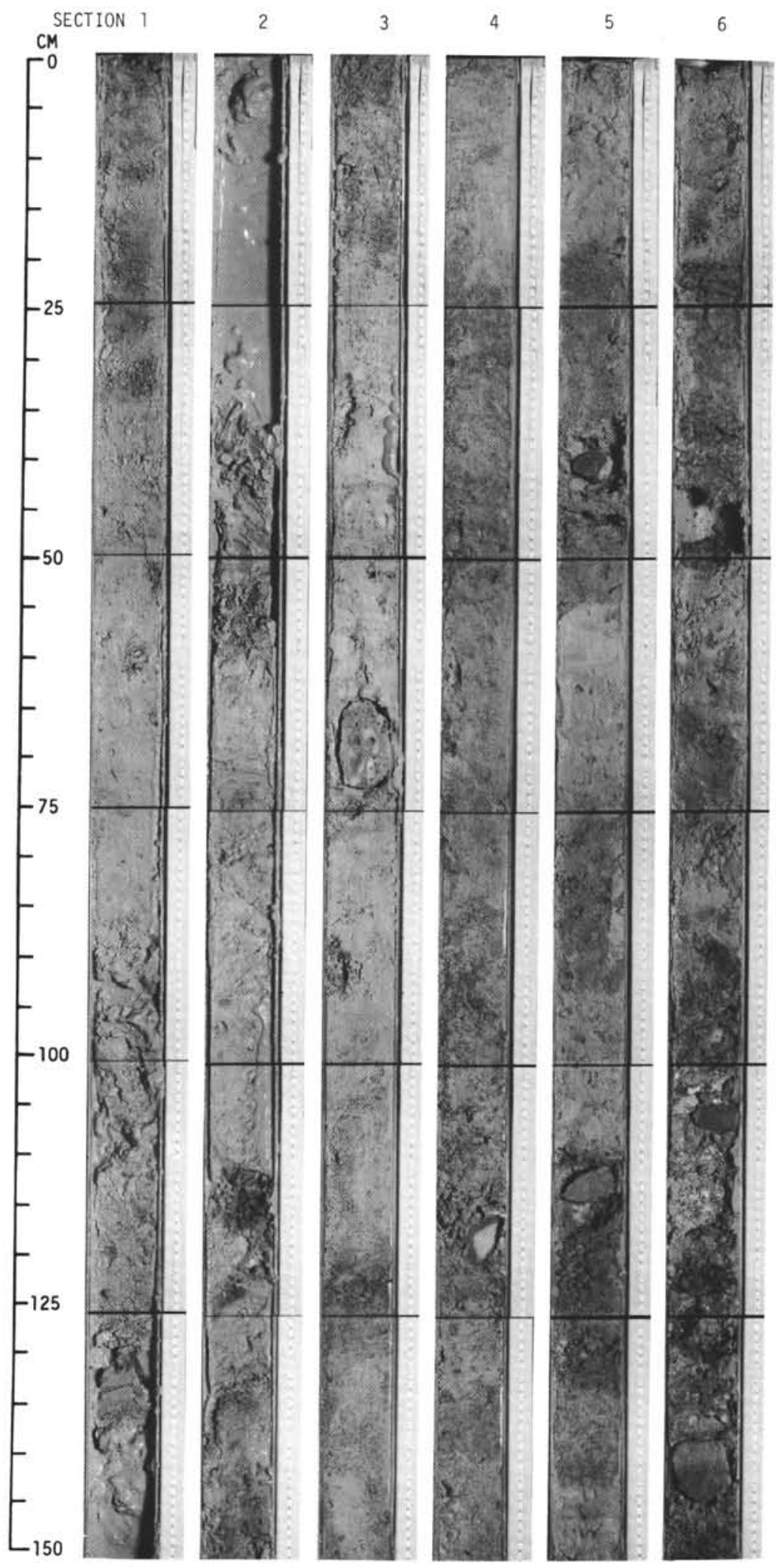




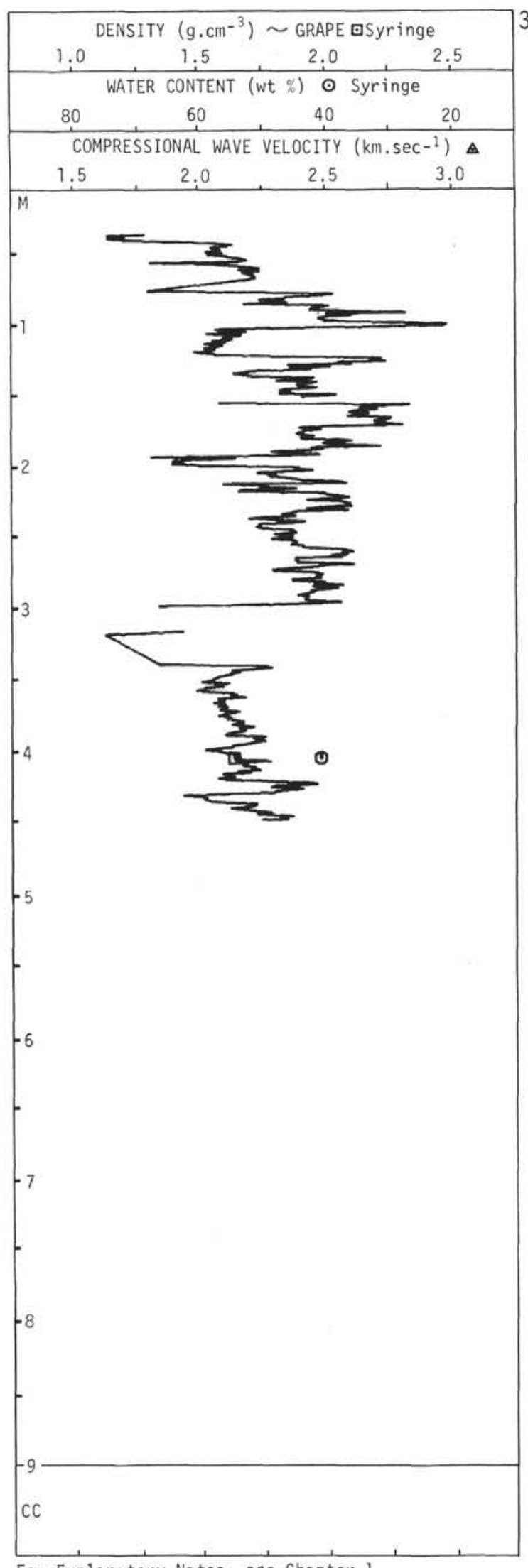

$352-5$

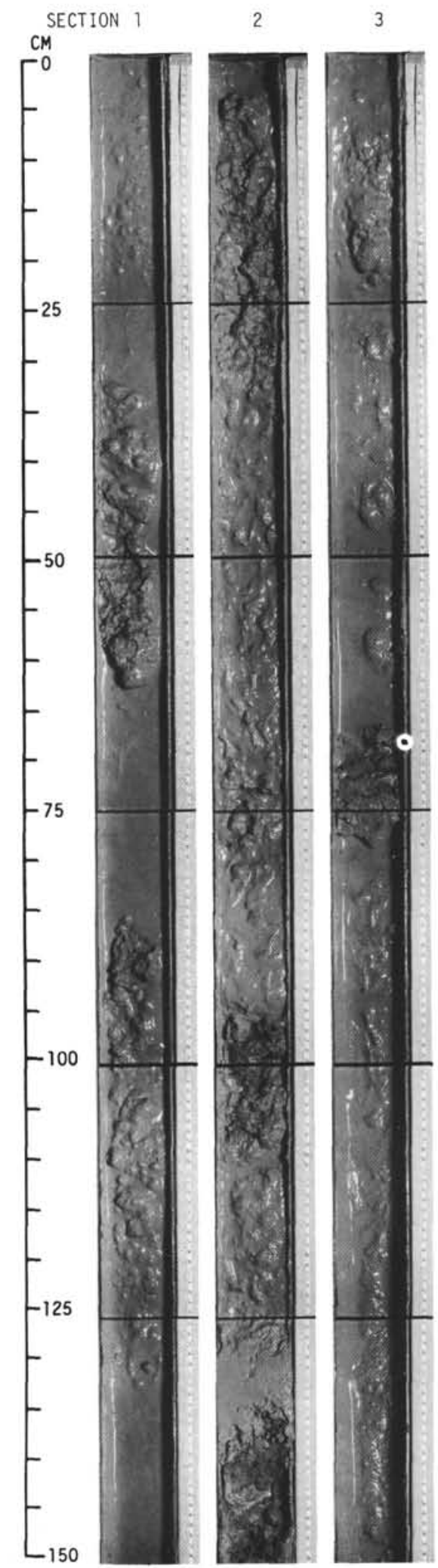




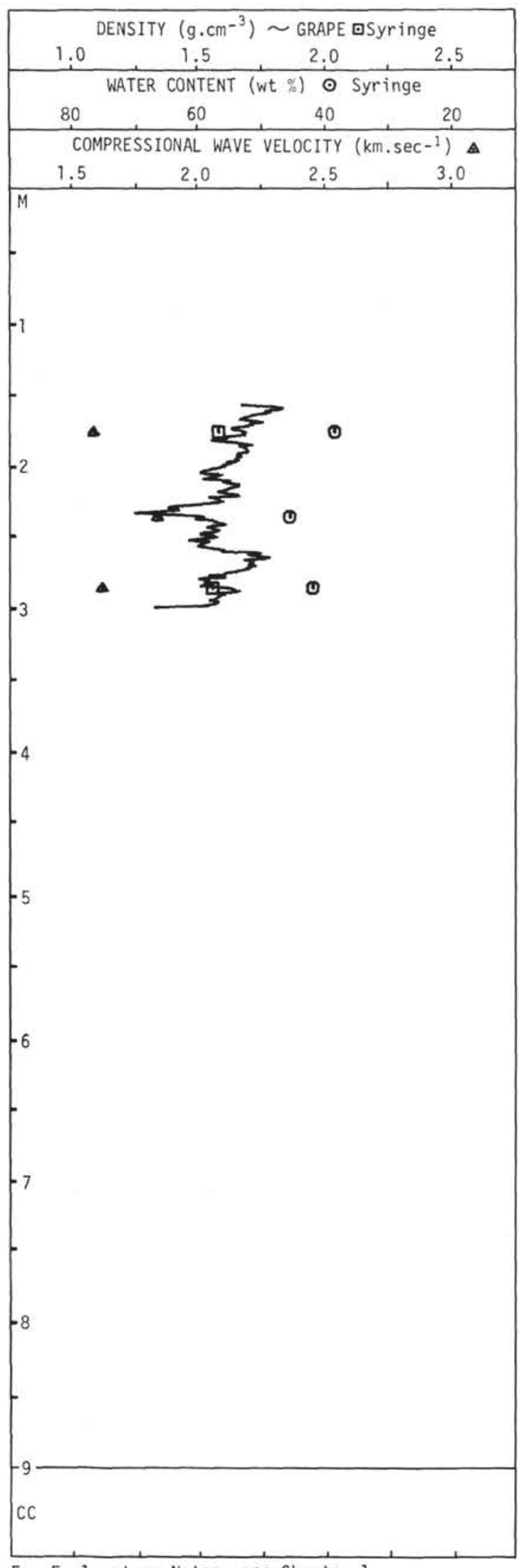

$352 A-1$

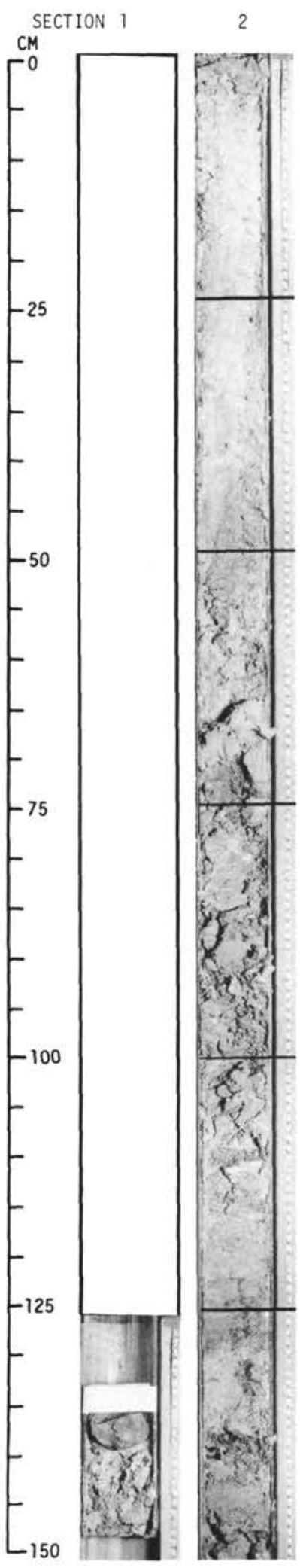




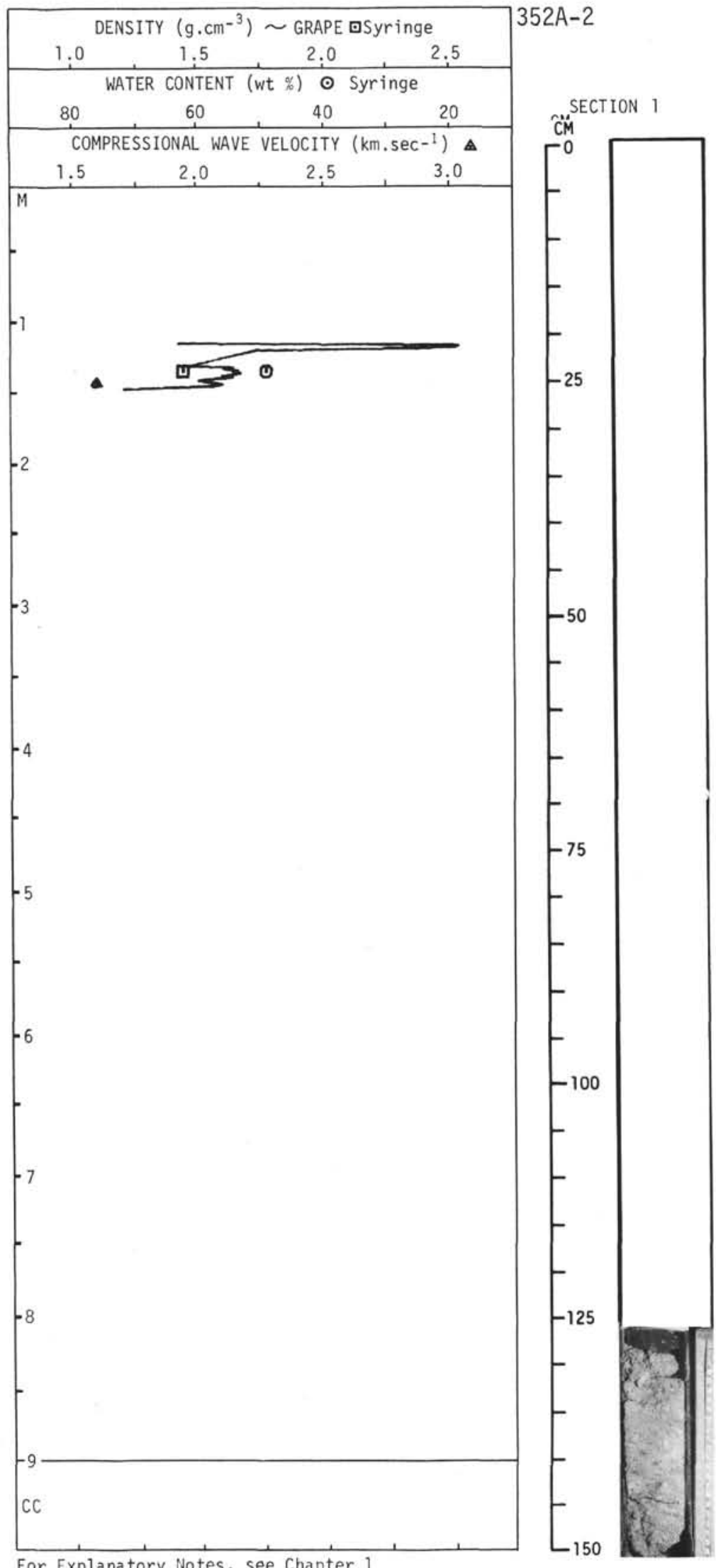




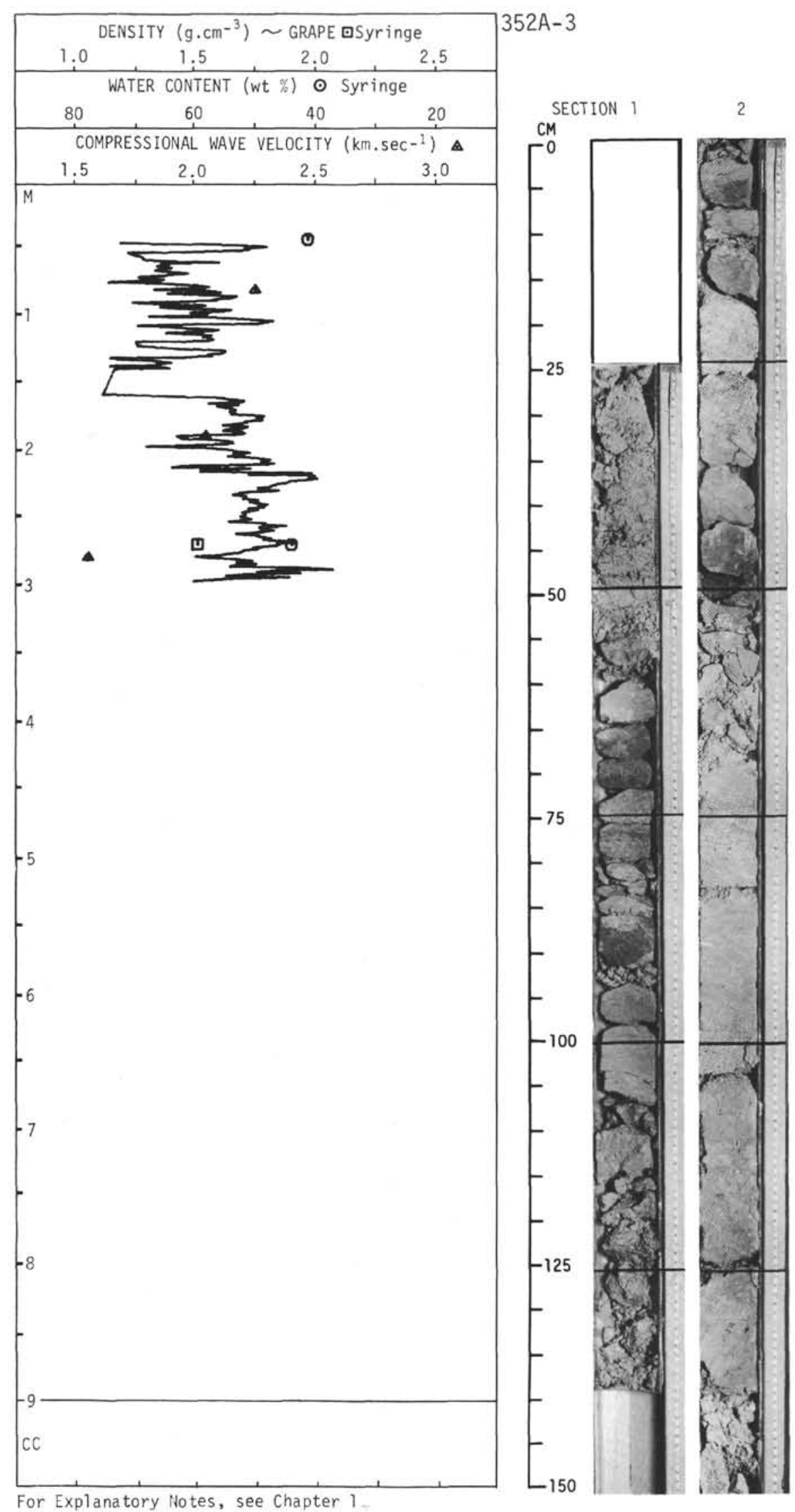

